Florida International University FIU Digital Commons

11-10-2009

\title{
The Electoral Geography of the Slovak Republic: A Comparison of the 1994, 1998, and 2002 Parliamentary Elections
}

Zuzana Hlavacova

Florida International University, Hlavaz@yahoo.com

DOI: $10.25148 /$ etd.FI09120809

Follow this and additional works at: https://digitalcommons.fiu.edu/etd

\section{Recommended Citation}

Hlavacova, Zuzana, "The Electoral Geography of the Slovak Republic: A Comparison of the 1994, 1998, and 2002 Parliamentary Elections" (2009). FIU Electronic Theses and Dissertations. 106.

https://digitalcommons.fiu.edu/etd/106 


\section{FLORIDA INTERNATIONAL UNIVERSITY}

Miami, Florida

THE ELECTORAL GEOGRAPHY OF THE SLOVAK REPUBLIC:

A COMPARISON OF THE 1994, 1998, AND 2002 PARLIAMENTARY ELECTIONS

A dissertation submitted in partial fulfillment of the

requirements for the degree of

DOCTOR OF PHILOSOPHY

in

INTERNATIONAL RELATIONS

by

Zuzana Hlaváčová

2009 
To: Dean Kenneth Furton

College of Arts and Sciences

This dissertation, written by Zuzana Hlaváčová, and entitled The Electoral Geography of the Slovak Republic: A Comparison of the 1994, 1998, and 2002 Parliamentary Elections, having been approved in respect to style and intellectual content, is referred to you for judgment.

We have read this dissertation and recommend that it be approved.

Elisabeth Prügl

Peter R. Craumer

Tatiana Kostadinova

Ralph S. Clem, Major Professor

Date of Defense: November 10, 2009

The dissertation of Zuzana Hlaváčová is approved.

$\begin{array}{r}\text { Dean Kenneth Furton } \\ \text { College of Arts and Sciences } \\ \hline \begin{array}{r}\text { Dean George Walker } \\ \text { University Graduate School }\end{array}\end{array}$

Florida International University, 2009 
(C) Copyright 2009 by Zuzana Hlaváčová

All rights reserved. 


\section{DEDICATION}

I dedicate this dissertation to my husband Bikal Gurung and to my parents, Ludovít Hlaváč and L’ubica Hlaváčová, for their love and support. 


\section{ACKNOWLEDGMENTS}

I would like to thank the members of my committee for their support, patience, and understanding. Dr. Ralph S. Clem, my major professor, has provided me with invaluable guidance and support in writing the dissertation. Dr. Clem's patience and his confidence in my abilities were critical in my completing the doctoral degree. Dr. Clem's extraordinary expertise in electoral geography was an inspiration to my research.

I would like also to thank Dr. Elisabeth Prügl for her support and for her valuable

feedback on issues of European Union enlargement in Central Europe. Dr. Tatiana Kostadinova was particularly helpful in guiding me toward key issues in the study of political parties and elections. Finally, Dr. Peter R. Craumer's guidance in statistics and data analysis of electoral and socio-economic data was indispensable. 


\section{ABSTRACT OF THE DISSERTATION}

THE ELECTORAL GEOGRAPHY OF THE SLOVAK REPUBLIC:

A COMPARISON OF THE 1994, 1998, AND 2002 PARLIAMENTARY ELECTIONS

by

\section{Zuzana Hlaváčová}

Florida International University, 2009

Miami, Florida

\section{Professor Ralph S. Clem, Major Professor}

In what can rightly be said to be one of the most dramatic geopolitical shifts in modern times, the collapse of communist regimes in Central Europe and the former Soviet Union brought about dramatic changes in the entire region. As a consequence, wide ranging political, economic, and social transformations have occurred in almost all of these countries since 1989. The Slovak Republic, as a newly democratic country, went through the establishment of the electoral and party systems that are the central mechanisms to the formation of almost all modern democratic governments. The primary research purpose of this dissertation was to describe and explain regional variations in party support during Slovakia's ten years of democratic transformation. A secondary purpose was to relate these spatial variations to the evolution of political parties in the post-independence period in light of the literature on transitional electoral systems.

Research questions were analyzed using both aggregate and survey data. Specifically, the study utilized electoral data from 1994, 1998, and 2002 Slovak parliamentary elections and socio-economic data of the population within Slovak regions which were eventually correlated with the voting results by party in the 79 Slovak 
districts. The results of this study demonstrate that there is a tendency among voters in certain regions to provide continuous support to the same political parties/movements over time. In addition, the socio-economic characteristics of the Slovak population (gender, age, education, religion, nationality, unemployment, work force distribution, wages, urban-rural variable, and population density) in different regions tend to influence voting preferences in the parliamentary elections. Finally, there is an evident correlation between party preference and the party's position on integration into European Union, as measured by perceived attitudes regarding the benefits of EU membership. 


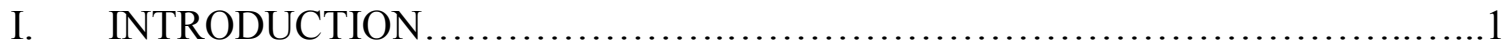

The Transition to Post-Communism: An Overview......................................4

The Central European Experience............................................. 5

Slovakia's Path to Post-Communism............................................... 9

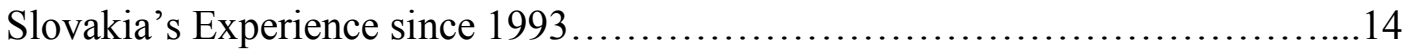

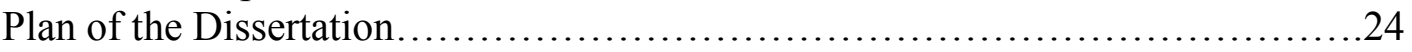

II. ELECTORAL SYSTEMS, PARTIES, AND VOTING BEHAVIOR IN POST-COMMUNIST STATES .............................................. 30

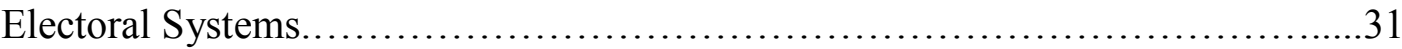

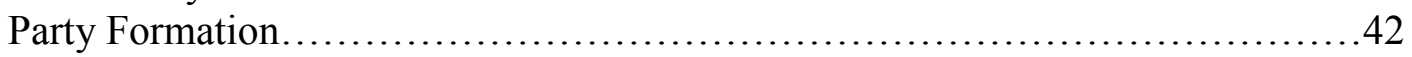

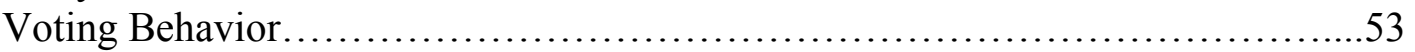

III. ELECTORAL GEOGRAPHY AND DATA AND METHODS......................76

Conceptualization of View on Electoral Geography.............................76

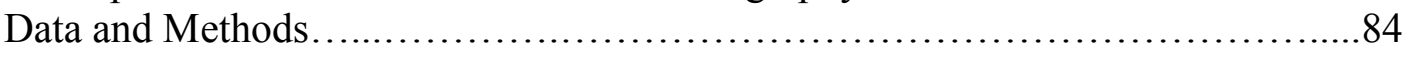

IV. VOTING RESULTS AND ANALYSIS OF REGIONAL VARIATIONS IN VOTING SUPPORT ...................................................... 99

1994 Slovak Parliamentary Election: Regional Patterns.........................198

1998 Slovak Parliamentary Election: Regional Patterns...........................113

2002 Slovak Parliamentary Election: Regional Patterns..........................123

Statistical Correlations and Survey Data.......................................139

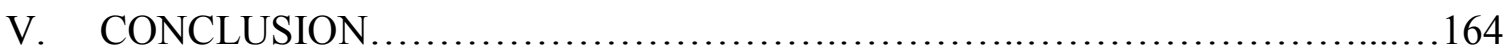

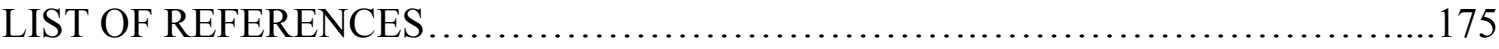

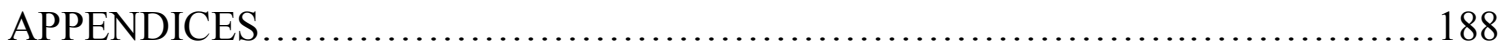

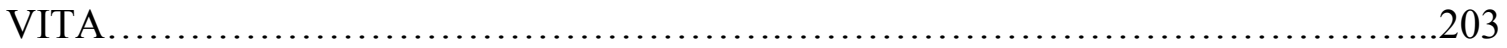




\section{LIST OF TABLES}

TABLE

PAGE

1. Winning political parties of 1994,1998 , and 2002 Slovak parliamentary elections...92

2. Slovak regions - socio-economic characteristics of the population

3. Socio-economic and the 1994 electoral data - Pearson correlations.

4. Socio-economic and the 1998 electoral data - Pearson correlations

5. Socio-economic and the 2002 electoral data - Pearson correlations

6. Voting preferences according to voters' education level (in \%)

7. Voting preferences according to voters' type of employment (in \%)

8. Voting preferences according to voters' age (in \%)

9. Voting preferences according to voters' household (in \%). .148

10. Voting preferences according to voters' nationality (in \%).

11. Voting preferences according to voters' household income (in \%)

12. Voting preferences according to voters' size of community (in \%) .153

13. Voting preferences by gender (in \%). 155

14. Stepwise regression - 2002 election. 160

15. Stepwise regression - 1998 election. 161

16. Stepwise regression - 1994 election. .162 


\section{LIST OF FIGURES}

FIGURE

PAGE

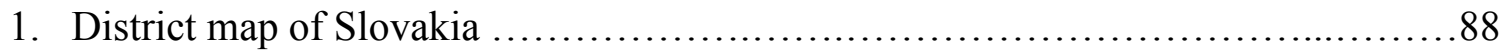

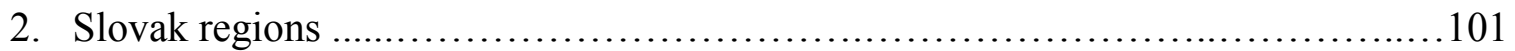

3. 1994 Slovak parliamentary election - percentage of valid votes for political parties or political movements .......................................... 110

4. Official results of the Slovak 1994 parliamentary election by region ..................113

5. 1998 Slovak parliamentary election - percentage of valid votes for political parties or political movements......................................... 115

6. Percentage of valid votes for a political party by districts - HZDS.................117

7. Percentage of valid votes for a political party by districts - SDK.................118

8. Percentage of valid votes for a political party by districts - SDL $\ldots \ldots \ldots \ldots \ldots \ldots \ldots 119$

9. Percentage of valid votes for a political party by districts - SMK-MKP ...........120

10. Percentage of valid votes for a political party by districts - SNS $\ldots \ldots \ldots \ldots \ldots \ldots \ldots 121$

11. Percentage of valid votes for a political party by districts - SOP $\ldots \ldots \ldots \ldots \ldots \ldots . \ldots 122$

12. 2002 parliamentary election - percentage of valid votes for political parties or political movements................................................ 126

13. Numbers of seats assigned to political parties............................... 128

14. 2002 parliamentary election - winning political parties in Slovakia by districts......129

15. 2002 parliamentary election - political parties with the highest number of

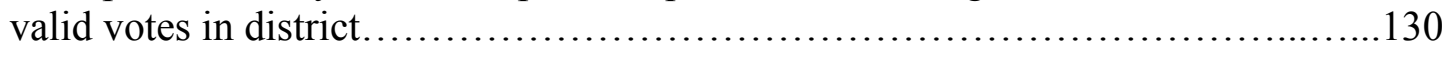

16. Percentage of valid votes for a political party by districts - SDKÚ.................131

17. Percentage of valid votes for a political party by districts - SMER................132

18. Percentage of valid votes for a political party by districts - ANO ................133

19. Percentage of valid votes for a political party by districts - SMK-MKP .............134 
20. Percentage of valid votes for a political party by districts - HZDS

21. Percentage of valid votes for a political party by districts $-\mathrm{KDH} \ldots \ldots \ldots \ldots \ldots \ldots \ldots$

22. Percentage of valid votes for a political party by districts - KSS...................137

23. Share of the number of participants in the referendum who answered - yes.........156

24. Share of the number of participants in the referendum who answered - no.............157 


\section{CHAPTER I}

\section{INTRODUCTION}

In what can rightly be said to be one of the most far-reaching and sudden geopolitical shifts in modern times, the collapse of communist regimes in Central, Eastern, and Southeastern Europe and the former Soviet Union brought about profound and largely unforeseen political, economic, and social changes throughout this large and strategically important region.

No less an authority than Samuel P. Huntington wrote: "the likelihood of democratic development in Eastern Europe is virtually nil" (1984, 217). Even in retrospect, it is almost beyond belief that five years after Huntington's prediction the Berlin Wall would come down and, in amazingly short order after that dramatic event, one-party authoritarian rule would be replaced by democratically elected governments, that socialist/command economic systems would yield to flourishing market economies, and formerly stodgy and retrogressive societies would become vibrant progressive cultures. Equally astounding is the fact that these ex-communist countries have now been fully integrated into the European Union (EU) and the North Atlantic Treaty Organization (NATO), indicative of their new status as full-fledged members of what we might call the New Europe.

Finally, as a consequence of this dramatic transition, the map of Europe has been redrawn, as Germany unified, the Czech Republic and Slovakia "divorced", and the USSR and Yugoslavia disintegrated. By no means is the process of geographic realignment yet fully resolved at this writing, as a "frozen conflict" persists in Moldova, the Crimean region of Ukraine with its ethnic Russian majority and huge Russian naval 
base remains a potential flashpoint, and ethnic tensions simmer in several of the former Yugoslav states.

For the post-communist countries, democratic transformation meant in the first place essential civil and political rights to free, equal participation in multi-party elections enjoyed by all competent members of society, and a replacement of the ineffective centrally planned economy, based on the dominance of state ownership, with a market economy. However, the transition period also has had fundamental human costs that affected all post-communist societies of Central Europe and the former Soviet Union as well. Impoverishment intensified, and income and wealth inequalities have widened. These social factors became common for all states in the region that were going through the transition process, and they in turn have had political implications.

Besides the importance of political and economic transformation, the transition of the post-communist countries also represents a very important geopolitical move - the shift of Central European states to the West. As Jacques Rupnik notes :“...the continent's geopolitical center of gravity has shifted eastward, to the center of Europe, while its institutional center of gravity has moved to the west" (Rupnik 2000, 121). To most of the people in these countries, the fundamental factor of transition was the change from being a satellite country of the Soviet empire to being part of the West. Thus, since the fall of communism, accession to the EU and NATO was one of the strategic aims of most Central European countries; membership in both organizations was strongly desired since accession would validate "the consolidation of the democratic process" (Bielasiak 2002, 1241). 
This dissertation will focus on the process of transition from one-party (communist) rule in one of the countries of Central Europe, Slovakia ${ }^{1}$. For Slovakia, as for the other post-communist countries, transformation meant in the first place essential civil and political rights and a series of free and fair multi-party elections engaging all eligible and duly registered electors; concomitant changes in the economic system involved replacing the ineffective centrally-planned economy based on state ownership with a market economy.

Until the 1980s, voters in Slovakia had no real political choices. However, the evolution of party systems in the post-communist countries brought a new range of opportunities and options to people living in this region. Post-communist countries, including Slovakia, accepted free elections as the basic principle of organizing power at the national and local level and chose the electoral system that was most suitable for their country. Of all of the remarkable changes that have occurred in post-communist states, as part of the transformation of the political system, multiparty elections are the most noteworthy feature and are deserving of our attention, not only for what the results imply for these states, but also for what this new wealth of experience with democracy adds to the scholarly literature.

As will be detailed later, the methodology used here to investigate questions relating to Slovakia's democratic transition is that of electoral geography, whereby spatial patterns of party and candidate choice and voter turnout and socio-economic and demographic data are analyzed to reveal the correlates of those political choices. These

\footnotetext{
${ }^{1}$ The transitional literature uses different ways to describe former communist countries of Central and Eastern Europe. For the purposes of this discussion, the term Central Europe will be used. Central Europe will include Poland, Hungary, the Czech Republic, and the Slovak Republic.
} 
results in turn are employed to assess hypotheses concerning voter behavior and attitudes drawn from the literature on electoral systems and democratization. As will be discussed further below, one crucial aspect of the Slovak case is the extent to which national elections turned on the question of EU membership.

\section{The Transition to Post-Communism: An Overview}

The transition to post-communism began in the Soviet Union when fifty-fouryear-old Mikhail Sergeevich Gorbachev came to power in 1985 (Sakwa 1991, 1). With the goal of modernization of the system and society, Gorbachev introduced radical policies of restructuring (perestroika), openness (glasnost) and democratization (democratizatsiya) (Breslauer 2002, 54). Furthermore, Gorbachev had "attacked many of the old Stalinist institutions as obsolete and self-serving, while promoting greater freedom of expression, contested elections at local levels, and an increased role for market mechanisms in the Soviet economy" (Snyder 1987-1988, 93). Gorbachev was optimistic that the reforms would improve the failing and technologically stagnant Soviet economy while building a better society based on "humane and democratic socialism" (Brown 2001, 35). In addition, while trying to strengthen the communist system, Gorbachev recognized that in order to implement such ambitious reforms, decentralization of institutional power would be required (Amann 1990, 292).

By allowing discussion about reform of the economic system and by permitting criticism of the primary features of the deteriorating economic management and planning, the Soviet leadership in a way acknowledged that the Stalinist model of a centrally planned economy was outdated and required reforms that would lead to continuous 
growth and technological advancement. Furthermore, by supporting rejuvenation of the Communist Party and encouraging Central European elites to liberalize their societies and implement their own perestroika, Gorbachev's policies led to fundamental political changes in Central European countries (Dawisha 1990, 148, 206-207; Breslauer 2002, $60)$.

Even though Gorbachev's primary strategy was to introduce much needed economic reform and thereby preserve the Soviet Union, these reforms started in turn a series of events that would ultimately result in the end of communist rule in Central Europe and indeed the collapse of the USSR itself. In turn, the forces unleashed by Gorbachev were to reverberate throughout Central Europe, eventuating in the overthrow of communist regimes throughout the region.

\section{The Central European Experience}

From the late 1940s on, the Central European countries closely followed the Soviet model in political, economic, and social spheres. At the political level, the countries of Central Europe adopted party, government, and institutional structures similar, if not identical, to those of the Soviet Union. The communist parties held a monopoly on power in one-party political systems established in Central Europe after the Second World War. In the social arena, political leaders, chosen by the Soviet leadership, implemented policies that included free education, health care, subsidized housing, and assurance of employment. In the economic sphere, the Central European countries established state-controlled centrally planned economies geared toward heavy industry, collectivization of agriculture, and state ownership of industry. Furthermore, three 
important institutions were established - the Communist Information Bureau (Cominform) replacing the old Communist International, or Comintern; the Council for Mutual Economic Assistance (Comecon); and the Warsaw Treaty Organization (Warsaw Pact) to strengthen common foreign, economic, and military policy respectively among the countries of the Soviet Bloc (Mason 1996, 16-17). The Soviet policies implemented in Central European countries came attached with a number of restrictions - censorship on media and independent organizations, as well as the increasing role of the pervasive secret police. Furthermore, the Soviet leadership used force and intimidation to consolidate communist power in Central Europe.

Since the beginning of Soviet hegemony in Central Europe, the Soviets experienced a number of challenges and protests from Central European countries. In 1956, demonstrations in Poland called for higher wages and better economic conditions, and in Hungary, demonstrators demanded the end of Soviet domination in the country and the return to power of former premier Imre Nagy, who was an advocate of the moderate communist policies (Mason 1996, 15-17, 22-23). Unfortunately, both of these attempts were brutally suppressed by military intervention. The events in Poland and Hungary were followed by the "Prague Spring" in Czechoslovakia in 1968, another example of a major challenge to Soviet hegemony and communist rule in Central Europe. However, as in the previous two cases, Czechoslovakia's call for democracy was put down by Warsaw Pact troops.

Implementation of reforms in the Soviet Union by Gorbachev precipitated the dramatic changes that occurred in Central Europe (Gokay 2001, 72). As Soviet control over Central Europe increasingly weakened, the authority and role of the region's 
communist parties was undermined. By clearly abandoning the Brezhnev Doctrine that justified the invasion of Czechoslovakia in 1968, the Central European countries realized that the Soviet Union could no longer maintain its effective control over them. Thus, the reform process in the Soviet Union accelerated the collapse of communist regimes in Central Europe, which in turn influenced still further movement away from communism in the Soviet Union.

The fall of communism in Central Europe began in Poland in the late 1980s. The demonstration of dissatisfied mining workers in August 1988 led by the Committee of Free Trade Unions for the Baltic Coast, named Solidarity (Solidarność) and the country's continuing economic problems eventually pressed the Polish government to try to find ways of collaboration with the political opposition, and as a result in April 1989 the Polish's United Workers' Party $(P Z P R)$ lost its dominance and became the first communist party to cede power (East and Pontin 1997, 16).

In Hungary, the Hungarian Communist Party also was pressed to implement much needed reforms due to massive public protests. Hungarian pro-reform communist leaders were quietly able to take over the government and implement political reforms such as multi-party elections and also introduce essential economic reform (East and Pontin 1997, 53).

At the same time, in East Germany, pressured by Gorbachev's calls for positive reforms, public demonstrations, a deteriorating economy, and worsening health conditions of the communist leader Erich Honecker forced his resignation. As a result of these events, the democratic opposition took the initiative to push for reforms. These events culminated in the lifting of strict travel restrictions that prevented East Germans 
from traveling to the West. This was followed by the fall of Berlin Wall on November 9, 1989 as well as the collapse of German Democratic Republic on October 3, 1990 (Mason 1996, 58).

After 1989, the newly democratized Central European countries were suddenly confronted with the enormous task of reforming their political, economic, and social systems simultaneously. In the political sphere, every country had to restructure its political system fundamentally, create a new constitution and legislation ensuring basic civil liberties, organize its first democratic elections, and allow the establishment of new interest groups and political parties. The elimination of the dominance of communist parties became a priority for Central European governments and fostered the proliferation of new political parties and implementation of multiparty elections. The communist parties in the Central European countries were forced to adapt to the transformation to multipartism, and Lenin's one-party ideology was replaced with democratic principles. With the introduction of a multiparty system, the communist parties lost their monopoly of power and had to become a real campaigning political subject competing for voters' support (Mason 1996, 99-100).

In the economic sphere, the collapse of socialist economies was also imminent. In the mid-1970's, countries of Central Europe and the Soviet Union experienced a period of stagnation. This was a warning sign of an upcoming economic crisis that resulted in the deterioration of living standards across the Soviet Bloc. The transformation to a market economy in Central Europe, along with the restitution of private ownership of property, was therefore essential. Central European countries chose between a gradual step-by-step economic reform and a quick, simultaneous approach, called "shock 
therapy" (Shaw 1999, 72-93). While trying to implement important reforms in all areas of life, Central European countries struggled with many problems such as economic deterioration, growing nationalism, and political instability.

\section{Slovakia's Path to Post-Communism}

To fully comprehend the development of Slovak democracy in the postcommunist era, it is imperative to understand the history of Czechoslovakia, the role of political parties and their linkages to voters, and to put Slovakia's transformation to democracy in this larger context, which is the focus of this dissertation.

Czechoslovakia was established as an independent country in 1918 as a result of the breakdown of the Habsburg monarchy and the spread of Western influence in Central Europe. Prior to unification, both Czechs and Slovaks were constituents of the Habsburg Empire. While both of them shared compatible languages, social structures, standards of living, and educational levels, there were several important differences between Czechs and Slovaks in their administrative and political expertise, ethnic and religious structures, and their levels of urbanization (Henderson 2002, 1-8).

Czechoslovakia had extensive experience when it came to democracy. In the period between the two world wars, among all Central European states, Czechoslovakia was considered one of the most democratic countries, with a Western type of political system. According to the 1920 constitution, Czechoslovakia was a parliamentary democracy with a multi-party system. However, this changed with the German occupation of Czechoslovakia in 1939 and with the establishment of a separate Slovak state led by Josef Tiso (Pithart and Spencer 1998, 185). This “...clerico-fascist Slovak 
state which emerged was nothing more nor less than a puppet-satellite of Nazi Germany" (Dowling 2002, 59). In 1944 Czechoslovakia was liberated from Nazi rule by the Soviet Red Army and the Czech and Slovak lands rejoined. However, this liberation did not come without consequences; it dramatically increased the strength of the Communist Party of Czechoslovakia and its influence on all aspects of the country's political and social life (Henderson 2002, 17). As a result of the 1946 elections, the Communist Party of Czechoslovakia established itself as the dominant political force in the country and in 1948 Czechoslovakia became a totalitarian country with an oppressive and rigid political system.

In the beginning of 1968 Alexander Dubček, an advocate of major system reforms, became the new head of the Communist Party of Czechoslovakia. Under Dubček's leadership, an Action Program, the reformist program of the Communist Party of Czechoslovakia, was introduced with the slogan "socialism with a human face (Dowling 2002, 107; Wheaton and Kavan 1992, 3-4). The Communist Party of Czechoslovakia chose an innovative strategy of no longer concentrating on the monopolization of its power, but instead putting a new emphasis on public support. This process, which was two decades later labeled by Gorbachev as glasnost, resulted in the elimination of censorship, allowing freedom of speech and expression, and the establishment of various civic political and social organizations that were beyond the scope of the party. Such an organization was Charter 77; established in 1977, it played a major role in the history of Czechoslovakia's struggle against the communist totalitarian regime. Among its members were elites of the future democratic Czechoslovakia who helped to bring down the communist dictatorship in the country, as part of the Velvet 
Revolution. Also, for the first time, public opinion played a significant role in these first attempts at democratization. Furthermore, democratic political forces outlined their political programs to confront the leading role of the Communist Party in the country. Consequently, the political system in Czechoslovakia increasingly began to bear a resemblance to the one of the pre-1948 period (Bankowicz 1994, 152-155).

However, the Soviet Communist Party grew gradually more alarmed at the direction Czechoslovakia was taking and made a decision to intervene and send troops to ensure return of Czechoslovakia to "communist normalcy". Accordingly, on August 20, 1968, Warsaw Pact forces took over Prague and major cities of Czechoslovakia and progress toward democratization was disrupted. The dramatic and, at times, horrific events of the Prague Spring were thus followed by the process of normalization which lasted for two decades. The new regime, led by communists, made a decision to keep Soviet troops permanently on the territory of Czechoslovakia and used internal security forces and other draconian instruments of state power to enforce civil obedience (Wheaton and Kavan 1992, 6; Bankowicz 1994, 154).

In 1988 the relationship between the Communist Party of Czechoslovakia and the Czechoslovak society worsened due to failing economic conditions in the country and also as a result of democratic transformations occurring in Poland, Hungary, and East Germany. There was an increase in public disapproval, which resulted in a new phenomenon of this era - public demonstrations. The unauthorized demonstrations, headed by elites representing the old dissident groups called for freedom in Czechoslovakia, for profound political and economic reforms, and mainly for abolishment of the Communist Party and the resignation of its leaders (Wheaton and 
Kavan 1992, 24). While the communists used brutal police force and imprisonment to stop demonstrators, it seemed as if that response produced even more demonstrations and a growing number of new opposition groups.

In June 1989, Charter 77 confronted the Communist Party of Czechoslovakia with the "'Several Sentences' in which the need for democracy, pluralism and tolerance in Czechoslovakia was emphasized". Václav Havel, a main activist in Charter 77, became a leading figure of the Velvet Revolution. Soon afterwards, by refusing to cooperate with the opposition, the Communist Party of Czechoslovakia was totally marginalized, and as a result of intense public pressure the party leadership was forced to resign (Bankowicz 1994, 156-157). The 1989 Velvet Revolution was without doubt the most important milestone in the history of modern Czechoslovakia. Moreover, the Velvet Revolution was part of the chain reaction that brought the end of the communist dictatorship not only in Czechoslovakia but throughout Central Europe.

With the help of two major political movements, the Public Against Violence (Verejnost' Proti Násiliu) in Slovakia and the Civic Forum (Občanské Fórum) in the Czech Republic and a number of dissident groups the end of communist rule was successfully achieved. At the same time however, a new tendency occurred, where rising ethnic tensions and conflicting political agendas between Czechs and Slovaks became evident. This division also continued in the 1990 election, which was the first free and democratic election after the country's transition from the communist regime. According to the 1968 constitution, Czechoslovakia was a federal republic, consisting of the Czech Republic and the Slovak Republic. The country had a bicameral federal legislature (Federálne Zhromaždenie) elected every five years. The Federal Assembly consisted of 
the House of Nations (Snemovña Národov) and the House of the People (Snemovňa Ludu) (Cox and Frankland 1995, 80). Furthermore, there were two Communist Parties in each republic running in elections separately.

As a result of the 1990 election, the Civic Forum in the Czech Republic with 49.5 percent of votes and the Public Against Violence in the Slovak Republic with 29.4 percent of votes won the election (Statistical Yearbook of the Czech and Slovak Federal Republic 1991). However, while anti-communism was a unifying force during the 1990 election, soon after the election, due to the fragile party organization structure and the lack of consensus within both parties, the Civic Forum and the Public Against Violence divided into various factions and by 1991 the two political parties disappeared from the political scene.

The common goal of ending the totalitarian system, which unified the country shortly after the break up of communist rule, was now no longer the crucial factor in the politics of Czechoslovakia. There were not only important cultural and economic differences between the Czech Republic and Slovakia, but also different approaches in party representation and political style. Moreover, the Czechs believed that Slovaks were taking advantage of their financial resources, while Slovaks felt often used by Czechs, who were stronger both politically and economically (Bankowicz 1994, 163). Consequently, these issues had a negative effect on the relationship between the two republics.

The result of the 1992 parliamentary election was the last significant factor that contributed to the dissolution of Czechoslovakia. In Slovakia, the leading Movement for a Democratic Slovakia with Prime Minister Vladimír Mečiar and the Slovak National 
Party were the strongest supporters of an independent Slovakia. In the Czech Republic Václav Klaus, the leader of the winning Czech Civil Democratic Party was also in favor of dismantling Czechoslovakia. Nonetheless, scholars suggest if a referendum would have been held on this question at that time, the Czech and Slovak people would most likely have supported preservation of Czechoslovakia (Shepherd 2000, 144-145). However, it never came to a popular vote, and the dissolution of Czechoslovakia was negotiated strictly by political elites. As a result of these events, on January 1, 1993, Czechoslovakia peacefully divided into independent Czech and Slovak Republics, the socalled Velvet Divorce.

\section{Slovakia's Experience Since 1993}

Slovakia's recent political transformation since 1993, as will be made clear below, is part of the wider Central European experience. The communist era had a strong effect on Slovakia. First, it resulted in low economic growth due to the command structure of economy, "the widespread alienation of the population from the political system, distrust of political leaders, lack of interest in joining political organizations and the erosion of morality in the public and private spheres" (Wolchik 1997, 202). Thus, the establishment of democratic political institutions after the fall of communism and the Velvet Divorce was problematic for Slovakia.

Slovakia experienced a number of setbacks while trying to establish stable democratic political institutions. The creation of political parties and groups in the country was a challenge that was affected by several factors. First was the country's precommunist and communist past, and its impact on the political values and attitudes of the 
citizens as well as political elites. Then, the effect of the break-up of Czechoslovakia in the process of building the state, and in addition the impact of personality and leadership on the development of the party system and Slovak politics in general (mainly the influence of Vladimír Mečiar) presented yet additional challenges (Dawisha and Parrott 1997, 198-199).

While Slovakia made great efforts towards establishing democracy, Mečiar, the leading figure of post-1989 Slovak politics, played a significant role in slowing down these efforts. Slovak politics were largely criticized not only by the domestic opposition, but also by the international community for following a nationalist and populist political program, and also for repeated violations of democratic principles by the country's government. Mečiar and his party - the populist Movement for a Democratic Slovakia (Hnutie za Demokratické Slovensko, or HZDS) had ruled unchallenged since the country separated from Czechoslovakia and became an independent state.

Mečiar created a poor image of Slovakia in the long term and, as a result, the country lost its opportunity to join NATO and the European Union in the first round with the so-called "fast-track" group of applicants - the Czech Republic, Poland, and Hungary. Although Slovakia was recognized for its strong economic performance on the one hand, the country was left off the invitation list due to its underdeveloped democratic institutions and Mečiar's ethnocentric and often brutal politics. As a result, Slovakia depicted an unfavorable image in Western countries and failed in foreign policy issues due to its democratic deficit.

After 1998, when the opposition coalition with Prime Minister Mikuláš Dzurinda came to power, the situation rapidly improved. Slovakia not only recovered its 
relationship with neighboring countries, but also began negotiations to join NATO, the European Union, and become a part of a democratic Europe.

\section{EU Enlargement}

For newly independent Slovakia, as well as other post-communist countries of Central Europe, the democratic transition was a significant geopolitical move to the West. For that reason, membership in the European Union (EU) and the North Atlantic Treaty Organization (NATO) became a primary foreign policy goal for the fledgling Slovak state. Furthermore, the European Union and other international organizations made a significant impact on incipient Slovak electoral and party politics. A large number of public announcements made by EU and NATO officials addressed to Slovak society helped to increase awareness of the importance of making pro-democratic electoral decisions and negative consequences if they did not (Korba 2003, 238-243). In addition, progress in European Union integration became part of the intense Slovak political contest.

During the communist era there was almost no relationship between the Central European countries and the European Community (precursor to the EU), which was the result of the negative attitude of the Soviet leadership towards the Western European states. Thus, enlargement of the European Union eastwards represented a great historical opportunity for the countries of Central Europe. Enlargement aspired to fill the gap caused by decades of East-West confrontation and the Cold War. Enlargement also symbolized the moral and emotional call for a united Europe. Political, economic, and security dimensions are additional aspects of EU enlargement eastwards. After the fall of 
communism in Central Europe, one way the European Union expressed its support for the process of democratization in the region was by providing financial and technical assistance to the newly introduced liberal democracies and market economies. One of the most significant aid programs was the PHARE (Poland and Hungary Assistance for the Reconstruction of the Economy) program aimed to reinforce the political and social basis of a liberal democratic political system (Gower 1999, 4).

"EU enlargement is not just a trivial bureaucratic exercise; it is a powerful generator of historical change in the region" (Ekiert and Zielonka 2003, 9-10). As noted, there were several practical or tangible reasons why becoming part of the European Union was so important for countries of Central Europe. But issues of European identity were probably the most significant motives. As a result of the Cold War, countries of the former Soviet bloc felt that they had lost their "European" identity, so for that reason becoming a member of the European Union was a way to "rejoin" Europe. The "return to Europe" was "...not only a symbol of the transition but also the guarantor of the systemic reconfiguration of the post-communist decade" (Bielasiak 2002, 1241). Therefore, accession into the European Union became a primary foreign policy goal for the governments of the Central European countries. The elites from the newly elected governments signed all necessary international agreements to make the integration process as swift as possible (Grabbe 2003, 68-69).

Furthermore, the former communist states believed that European integration would be the best guarantee for continuation of the path towards a united and prosperous Europe based on values of democracy and human rights. In addition, for almost all postcommunist states, joining the European Union was always a symbol of reintegration into 
the world economy and pan-European markets. Membership in the EU offered vast economic advantages that include increased foreign direct investment and technology transfers as well as financial assistance programs aimed to support a long-term economic growth. For those reasons all Central European countries began fundamental reforms to establish liberal democratic political systems and market economies. They were determined to fulfill all necessary requirements and obligations to become part of the European Union in the shortest possible time.

However, integration into the European Union was not an easy task; rather it was a major challenge as well as a complex process that demanded considerable time. It is important to note that no previous applicant began the integration process at such a low starting point as did the nations of Central Europe. Becoming a member of the European Union requires commitment from the government of each country and it involves a difficult transformation of a country's political institutions, economy, laws, culture, and society. In addition, the European Union itself has a long list of rules and conditions in political and economic sphere fulfillment of which is a prerequisite for membership.

From the beginning, the integration process involved several levels that had to be accomplished in order for Slovakia to become a permanent member of the European Union. The first prerequisite was Slovakia's participation in the institutional structures of the European Union. The second prerequisite for European Union membership was adoption of the EU's existing legislation, the acquis communautaire, which embodied the establishment of the institutional and regulatory framework of the EU. Moreover, this prerequisite of membership allowed Slovakia to access the European Union's funds and programs (Cameron 2003, 24-29). 
After the division of Czechoslovakia, the Slovak Republic acquired associate member status, and in 1993 Slovakia signed the so-called "Europe Agreement" with the European Union countries as part of the framework for gradual political and economic integration (Škrabala 2002, 1). While the Slovak government, headed by Prime Minister Mečiar, publicly expressed its commitment to democratic values, in reality the European Union was disappointed by the actions of the Mečiar administration.

In 1995 Mečiar submitted a formal application of the Slovak Republic for European Union membership to the European Commission (Škrabala 2002, 1). However, bad news for the future of Slovakia came in July of 1997 when the European Commission (EC) informed Mečiar's government that the country had not succeeded in meeting adequate political conditions set by the Copenhagen European Council for EU membership. As a result, the Commission made a recommendation to exclude Slovakia from the first group of states with which European Union accession talks were to begin in early 1998 (Hamžík 1998, 213-219).

The EU's Copenhagen criteria provided the framework for the assessment of Slovakia's eligibility for membership in the European Union. According to these criteria membership requires “....stability of institutions guaranteeing democracy, the rule of law, human rights and respect for and protection of minorities, the existence of a functioning market economy as well as the capacity to cope with competitive pressure and market forces within the Union" (Pridham 2002, 224). While it was affirmed that Slovakia had achieved positive economic progress, and would be able to meet the necessary economic criteria, the country did not accomplish fulfillment of the political conditions set out by the European Council in Copenhagen because of the "instability of Slovakia's 
institutions, their lack of rootedness in political life and the shortcomings in the functioning of its democracy" (European Commission 1997, 125-130). Although the European Commission pointed out that free and fair elections had been held in the country, the EC was not satisfied with the respect for ethnic minorities in Slovakia, especially when it came to exercising rights of the Hungarian and Roma minorities. While improvement in certain areas was highlighted, as in the case of the Hungarian minority, the European Commission emphasized the substantial discrimination of the Roma population on a daily basis, including their lack of protection from the police and being subjected to continuous attacks from neo-fascist "skinheads" (Newton and Walsh 1999, 266-268).

Other reasons that made Slovakia fail the required political criteria were the feud between the Slovak President and Prime Minister, disrespect for verdicts made by the Constitutional Court, deterioration of freedom of expression in the media, the unsuccessful quest for the elimination of corruption, attacks on representatives of media, academia, religious leaders and non-governmental organizations, and questionable use of police and secret service by the government (Newton and Walsh 1999, 266).

The undemocratic practices of Mečiar's administration also contributed to the deterioration of Slovakia's image abroad. In addition, as a result of Mečiar's authoritarian tactics, the relationship between the Slovak government and the European Union became extremely antagonistic. Not becoming part of the first group of countries set for negotiations for European Union membership was very unfortunate for Slovakia, since the country was the only one from the group of Central European states that was singled out for delay. Nevertheless, instead of making appropriate changes, the Slovak 
government persistently denied all accusations voiced by the Commission and continued to ignore the EC's requests for improvement, which were sent in the form of declarations and demarches. Perversely, Mečiar's administration continued passing legislation that seemed to disregard EU rules and expectations. Consequently, it was not clear whether Slovakia could possibly catch up in the speedy integration with "fast track" candidates such as the Czech Republic and Hungary (Newton and Walsh 1999, 253-263). Although Slovakia's chances to become part of the European Union were not permanently eliminated, it was evident that only a new government could return Slovakia to the path of European integration.

As mentioned earlier, the process of Slovak accession into the European Union was slowed down from the start owing to the policies and practices of Vladimír Mečiar, who ruled the country as a Prime Minister from 1994 to 1998. Slovakia's failure to receive an invitation to the first EU accession group was largely due to Mečiar's leadership. As a result, the Slovak people became more vocal in voicing their support for democratic principles in the 1998 parliamentary election. Therefore, some part of Mečiar's defeat in that election is attributable to Slovakia's problems with EU accession.

After the 1998 parliamentary election, when the opposition coalition with Prime Minister Mikuláš Dzurinda came to power, the situation rapidly improved. Slovakia not only recovered its relationship with neighboring countries, but also began negotiations to join the European Union as a country of the "fast track" group. Thus, at the end of 1998 the European Commission, although pleased with the results of the parliamentary elections, however emphasized important steps Slovakia still needed to take in order to achieve the necessary political progress. After fulfillment of these political changes, such 
as adoption of the law on the use of minority languages and providing stability of political institutions, the European Commission expressed its satisfaction with the overall status of Slovakia.

In January 1999, as part of the preparation for European Union membership, the Slovak government accepted a list of 86 tasks set by the EU that would prepare different sectors for the integration process. By the end of the 1999, the Helsinki Summit decided to open negotiations with Slovakia, as well as other candidate countries, on the process of enlargement. Later in 2000 the European Parliament approved a resolution on enlargement of the European Union to countries of Central Europe by 2004 (Škrabala 2002, 2). The hope was that the Slovak Republic would still be able to join the European Union in the first accession group.

In early 2002, the European Commission released its report on progress in preparation for the integration of Central European and other states into the European Union. Based on an economic and political assessment, ten of thirteen candidate countries - the Czech Republic, Poland, Slovenia, Hungary, Latvia, Lithuania, Estonia, Cyprus, Malta and the Slovak Republic - met all required criteria for EU membership. Based on the decision made at the 2002 Summit of the European Union in Copenhagen, the Slovak Republic was among ten candidates recommended for integration into the European Union in May 2004 (Škrabala 2002, 3).

In May 2003, Slovakia held a referendum on EU membership asking Slovak citizens whether they agreed with the proposal that the Slovak Republic should become a member country of the European Union. Fifty-two point two percent (52.2) of eligible voters participated, 92.5 percent of which expressed their support for integration into the 
European Union (Statistical Office of the Slovak Republic 2003). As a result, the road to the EU was now clear. This was a profound accomplishment for Slovakia and other postcommunist countries that were among the first group in the EU enlargement process after the fall of communism in Central Europe. Moreover, this was the largest enlargement in the history of European Union.

On May 1, 2004 Slovakia along with nine other countries officially became part of the European Union. Joining the European Union was definitely a major step towards reaffirmation of the country's status as a modern European state. The European Union is not only a central international and regional organization, but also a major source of aid, trade, and investment. Moreover, many Slovaks, as well as people in other Central European countries, hope that with accession to the European Union they will be able to enjoy similar benefits and standards of living as previous EU member states. Such benefits include political stability, the EU's financial assistance, higher rates of economic growth, employment opportunities, and fair competition in a wider zone of peace, security and justice.

However, in particular, European Union enlargement had an enormous influence on post-communist electoral politics in Slovakia. In the past decade there were consistent and intensive pressures and warnings from the international community, especially from the representatives of the European Union and NATO, to Slovak voters not to choose Mečiar as the country's future leader; otherwise, there was no chance for Slovakia to become integrated into the democratic West. For example, prior to 2002 election US Ambassador to NATO Nicholas Burns announced: "no undemocratic movement, party or government has any place in NATO. We are convinced that the previous [Slovak] 
administration did not show respect for democratic values and the rule of law... There is no evidence that the leadership of the previously ruling party has changed" (Korba 2003, 238). Representatives of the European Commission and European Parliament confirmed that the 2002 parliamentary election symbolized for Slovakia a possibility to prove their interest and their readiness for European democracy. Therefore, partially as a result of these pressures, results of the 1998 and 2002 parliamentary elections demonstrated that Slovakia remains on the democratic path and has fulfilled all political requirements mandatory for membership in the European Union. European Union membership also became part of a strong political rivalry in Slovakia itself. As Milada Vachudova asserts, the stringent requirements for EU membership had a strong influence on emerging party systems in newly established democracies. To gain support of voters, major political parties used possibility of EU membership towards their advantage by adopting political agendas that were in line with membership requirements (July 2009, 179-180; 2008, 861). Furthermore, mass attitudes not only contributed to the establishment of democratic system in Central Europe, but they also played a key role in the success of new institutions and reforms associated with the EU membership. Political parties had an important role in shaping public attitudes towards the European Union enlargement. Therefore, political parties matter to European Union membership.

\section{Plan of the Dissertation}

Given this background, the issue to be studied is the electoral geography of the Slovak Republic and what that tells us about the country's transition to multiparty democracy. Within that broad subject, I first describe and then analyze regional variations 
in voting behavior in post-communist Slovakia. The Slovak Republic, as a newly democratic country, provides an excellent case with which to examine how and why the country's electoral geography changed during the democratic transformation. Because fair democratic elections are crucial for the functioning of democratic interest intermediation, this study concentrates on the role of political parties and their linkages to voters. More specifically, based on case study of Slovakia, I examine how and propose reasons why electoral support changed or not within various geographic regions during the country's ten years of democratic transformation.

The circumstances I investigate include two periods of transition to democracy, and the preparatory period for European Union accession. Accordingly, I test hypotheses in three different electoral settings within Slovakia:

- The 1994 parliamentary elections

- The 1998 parliamentary elections

- The 2002 parliamentary elections

Thus, the primary purpose of this dissertation is to describe and explain regional variations in party support during Slovakia's ten years of democratic transformation by reference to social and economic characteristics of the population in the regions of Slovakia. A secondary purpose is to relate these spatial variations to the evolution of political parties in the post-independence period in light of the literature on transitional electoral systems. Finally, I focus in part on the manner in which a party's stance on EU accession relates to its electoral strength in the regions. 


\section{Research Problem}

There are two facets of the research problem: (1) explaining party and candidate preference, and (2) explaining differences in voter turnout.

\section{Research Questions and Hypotheses}

Question \# 1: What is the electoral geography of Slovakia and how has it changed, or not, during the decade of the country's democratic transition?

Question \# 2: How do the socio-economic characteristics of the Slovak population in different regions influence voting preferences in the parliamentary elections?

Question \# 3: In terms of European Union enlargement, is there a correlation between voters' preferences of political parties and the way the public perceives political parties in government either as advocates of European Union membership or in contrasting stance? Hypothesis \#1: There is a tendency among voters in certain regions to provide continuous support to the same political parties/movements over time.

Hypothesis \#2: Socio-economic characteristics of the Slovak population (gender, age, education, nationality, employment, income, type of household) in different regions tend to influence voting preferences in the parliamentary elections.

Hypothesis \#3: There is a correlation between party preference and a party's position on integration into European Union, as measured by perceived attitudes regarding the benefits of EU membership.

\section{Significance of the Study}

The Slovak Republic, as a newly democratic country, went through the establishment of the electoral and party systems that are the central mechanisms to the formation of almost all modern democratic governments. There remains a large gap in 
research on the electoral geography of the newly democratic countries, such as the Slovak Republic. Thus, the dissertation will make an empirical contribution not only to the study of electoral geography, but also to the understanding of political party formation in Central Europe and, in particular, Slovakia. Further, the results of this study will inform existing theory or concepts by testing relationships between socio-economic correlations and voting patterns, and by explaining regional variations in the spatial pattern of party support. In addition, my dissertation tests correlations between party preference and a party's position on European Union membership, proving that integration into the European Union has a significant impact on domestic politics in Slovakia.

\section{Organization of the Study}

Chapter 1 provides the historical context in which Slovakia made its transition to multiparty democracy. The discussion starts with a brief synopsis of the Soviet experience, and continues with the struggle of the Central European countries to democratize that slowly began under communist regimes and consolidated after the fall of communism. Furthermore, the case of Czechoslovakia is introduced, including a short history of the country, followed by the discussion of Velvet Divorce and the unstable period of Mečiar's government in the now-independent Slovakia. The chapter also highlights the enormous importance of the EU in post-communist electoral politics. In addition, Chapter 1 presents the general statement of problem area, research purpose, research problem, research questions and hypotheses, and significance of study.

Chapter 2 presents the literature review of party formation, the choice and implications of electoral systems, and the determinants of voting behavior, in general and in the post-communist states. The chapter discusses the main types and elements of 
political parties and electoral systems chosen by countries of Central Europe after they began their process of democratization. Furthermore, the strengths and weaknesses of various kinds of electoral systems are illustrated. In addition, the chapter identifies the effects electoral systems may have had on party formation in Slovakia and other countries in transition.

Chapter 3 provides the review of the literature on electoral geography as a methodology using aggregate data, including comparisons with studies employing survey or individual level data, and a detailed discussion of the methods and data used in the study.

Chapter 4 presents the case of Slovakia. A description of the Slovak electoral system and different types of political parties in Slovakia is presented. Furthermore, the electoral geography of Slovakia based on the 1994, 1998 and 2002 Slovak parliamentary elections is discussed and analyzed. The chapter explains the electoral geography of Slovakia and how has it changed during the ten years of Slovakia's democratic transformation. Explanations of party and candidate preference, as well as differences in voter turnout are offered. The chapter also provides conclusions on how the socioeconomic characteristics of the Slovakia's population in different regions affect voting preferences in the parliamentary elections. In addition, in terms of European Union enlargement, the chapter makes conclusions on whether there is a correlation between voters preferences of political parties and the way the public perceives political parties in government either as advocates of European Union membership or in contrasting stance. 
Finally, Chapter 5 summarizes the major findings and conclusions and relates the same to the aforementioned literature. This chapter also offers specific implications for regional variations in voting behavior in post-communist Slovakia. 


\section{CHAPTER II}

\section{ELECTORAL SYSTEMS, PARTIES, AND VOTING BEHAVIOR IN POST-COMMUNIST STATES}

Democracy is a political system characterized by regular competitive elections, multiple parties and candidacies, and freedom of the press. (Parrott 1997, 4). Therefore, the implementation of competitive elections is a precondition for any democratic system, and essential to the long-term legitimacy of the liberal democratic state. After the fall of communism in Central Europe, all post-communist elites acknowledged their commitment not only to democratization but also to the creation of democratic electoral systems and liberalization of electoral rules. Further, all of the states of Central Europe in fact held multiparty elections subsequent to the end of communist rule according to whatever electoral system that each had adopted. These elections provide us with a wealth of data with which to study the effects of electoral systems, the genesis of postcommunist parties, and the determinants of voting behavior. A large, and growing, literature has emerged on the transition to democracy in the region, and relevant studies will be reviewed in this chapter.

The choice of an electoral system has several profound implications for the manner in which democratization occurs, including issues of representation and the formation of political parties, these, of course, similarly being crucial to competitive elections. Accordingly, we first review the general literature on electoral systems and then specifically discuss their implementation in the post-communist states of Central Europe. In addition, in light of this review, the chapter discusses party formation in the post-communist countries and identifies the effects electoral systems may have had on 
party formation in the transition countries. Furthermore, a review of literature on models of voting behavior in the post-communist countries and factors that influence voter choices is provided. Finally, each of the foregoing is related directly to the case of Slovakia to provide the conceptual context for the data analysis that follows.

\section{Electoral Systems}

As Farrell notes, "Electoral systems determine the means by which votes are translated into seats in the process of electing politicians into office" $(2001,4)$. Thus, the electoral system is the major institutional aspect that affects the development and nature of the country's party system. Scholars argue that the nature of the electoral system influences the type of party system and the number of parties that develop by affecting strategic thinking of voters and political elites. Further, electoral systems define how political systems will function and ensure their legitimacy. Countries select their electoral system to assemble powerful and steady governments, fulfill voters' preferences, and elect competent candidates (Farrell 1997, 2-3). Electoral systems not only shape the number of major political parties operating in a country, but they are also the subject of struggle and manipulation by politicians, because of their effect on political outcomes.

Recent change in Italy's electoral system is an example of such manipulation by political leaders. Italian Premier Silvio Berlusconi, the media mogul and businessman who has influenced practically every sphere of Italian economic and social life, pressed for change from a mixed to a proportional representation electoral system. Berlusconi's government modified Italy's electoral system less than four months before the 2006

election. The new electoral system was established with very low thresholds, 4 percent 
for a political party and 2 percent for coalition, thus encouraging political parties to join the coalitions. Furthermore, Berlusconi's political party Forza Italia was formed only a few months prior to the 1994 election and still was able to win the election. Clearly, the dramatic changes occurring in post-communist countries have some similar features with the changes happening in long-standing electoral democracies such as Italy (Belluci 2008, 185-188; Hopkin 2004, 5).

According to Arend Lijphart, there are three main types of electoral systems used in the post-communist countries of Central Europe: majority-plurality, proportional representation (or PR), and semi-proportional electoral systems $(1994,10)$ :

Majoritarian systems can be divided into three subtypes - plurality, two-ballot, and the alternative vote systems. There are a large number of districts in all majoritarian systems that are often equal or close to the size of the legislative assembly. In majoritarian systems there is an evident tendency for favoring large political parties, which causes disadvantages to small parties, and consequently results in disproportionality of electoral outcomes (Lijphart 1994, 18-21). Furthermore, in a weak party situation the majoritarian system undermines the status of parties by allowing the proliferation of independents. In summary, majoritarian systems are not only less representative, but they are also a discouraging factor to the formation of a multi-party system. On the positive side, by providing two-party majority governments, majoritarian systems are much more stable than multiparty coalitions in PR systems (Moser 2001, 32).

Proportional Representation (PR) systems are not only the most common type of electoral systems, but moreover they were chosen by many post-communist countries due to the fact that with a PR system a country could achieve greater proportionality and 
probably better minority representation than with a majoritarian system. For example, small political parties have a much better chance to receive representation (i.e., to win legislative seats) in a PR system than in a majoritarian system, where in most cases only two political parties compete. Maurice Duverger argues that "proportionality results in a multiparty system; the more proportional the system, the greater the number of political parties" $(1963,205)$. The main limitations of a PR system are its failure to promote the nationalization of parties in regions; its emphasis on charismatic leadership; its tendency to promote ideological extremism and polarization; and the proliferation of parties, e.g., Russia with 43 parties in 1995. However, Lijphart asserts that proportional representation systems allow better representation of minorities, implying that proportional representation systems are therefore the best alternative for new countries in transition (1994, 10-25).

In semi-proportional electoral systems, or mixed electoral systems, representatives are "elected in both party-list (PR) contests in large multimember districts and plurality or two-round majoritarian elections in single-member districts" (Moser 1999, 365). It is argued that mixed electoral systems have a tendency to generate moderate levels of disproportionality and multipartism. Therefore, many post-communist countries opted to use this type of electoral system.

According to electoral studies, several elements of electoral systems affect not only proportionality of the electoral system, but also party formation in the postcommunist countries. The most important among them are legal threshold, electoral formula, and district magnitude. 


\section{Legal Threshold}

The legal threshold is the least amount of support that a political party needs to attain to obtain representation (seats). It is typically implemented at the national level, but also could be implemented at the regional or district level. This minimum could be characterized by the country's electoral law as for example a minimum percentage of votes, or certain number of votes that a party is required to obtain in order to qualify for legislative seat distribution. The increased legal threshold encourages party consolidation by decreasing representation of small political parties. Overall, the high legal threshold could have the same function as low district magnitudes (Lijphart 1994, 11-12).

\section{Electoral Formula}

The second significant element of electoral systems and party formation is the electoral formula, which is a procedure for converting the number of votes into seats. In general, there are four most common electoral formulas: mixed, PR, plurality, and tworound majoritarian. In mixed systems, which represent a combination of PR and majoritarian systems, voters cast two ballots in different electoral tiers. In a PR system, even though the electoral formula differs, there is always competition between lists of candidates in multimember districts, and seats are allocated in accordance with the number of votes in a district.

The two-round majoritarian electoral formula is held in a single-member district, where the winner must get a majority of votes cast. In case no candidate receives a majority, a second round is held generally between the two candidates who obtained the highest number of votes in the first round. In addition, according to the plurality formula 
the candidate with the most votes in a single-member district (SMD) wins the election despite the number of votes cast (Moser 2001, 33-34).

\section{District Magnitude}

Another element of electoral systems that can affect multi-party systems and overall proportionality is district magnitude - the number of representatives allocated for a district or constituency (Taagapera and Shugart 1989, 13). Based on district magnitude, a country could be divided into many electoral districts, each district sending one representative to the legislature (SMDs); an all-national electoral district that comprises all representatives; or territorial multimember districts with two or more representatives (Moser 2001, 33-34). Douglas Rae points out that there are three stages in the change of votes into seats: balloting, districting, and the electoral formula. Rae emphasizes that there is a difference between the term district magnitude (the number of seats in a district) and district size. Furthermore, Rae asserts that district magnitude has a greater influence on proportionality than the electoral formula (1967, 6, 114-125).

\section{Other Features of Electoral Systems}

In addition to these main elements of electoral systems, there are several other features that could also have an effect on party formation and proportionality of the system - assembly size, ballot structure, apparentement, presidentialism and the possibility of malapportionment. 
- Assembly size is the dimension of the electoral system, which represents the total number of seats in the legislature. Assembly size can affect the outcome of party representation when the total number of votes is translated into seats.

- Ballot structure is another aspect of electoral systems which can very much shape party formation. It can be ordinal, allowing voters to split their votes among two or more political parties, or categorical, if the voters can choose only one political party.

- Apparentement is when voters choose from a group of inter-party lists and parties then combine the votes to allot seats. This is specific primarily for PR systems. The approval of use of apparentement could be very important for small parties, since almost all types of electoral systems are partial to larger political parties.

- Presidential systems could have a significant influence on legislative elections and multi-party system, if presidential and legislative elections are held concurrently. In presidential elections, only large parties have a chance to nominate their candidates for the post, thus small parties are disadvantaged, and as a whole presidentialism could be an obstacle to the maturation of multi-party systems.

- Malapportionment, or disproportionality, could occur in single-member district systems, where districts have uneven voting populations, or in multi-member districts, where magnitudes are not equivalent with the voting populations (Lijphart 1994, 12-15).

\section{Electoral Systems in the Post-Communist Countries}

The democratic transition in the post-communist countries began with the establishment of new electoral systems. Elections were held with multi-party representation, which resulted in a rapid proliferation of political parties of all types. 
Poland was the first Central European country that was able to break free from communist rule and turn the nation towards a democratic path. As many other postcommunist countries, Poland adopted a PR electoral system. Poland's parliament was established with two chambers - the Sejm and the Senate. The Sejm has 460 members, elected for a four-year term by proportional representation. Originally, there was no electoral threshold established, however due to high levels of party proliferation during 1991 election, the threshold was later adjusted to 5 percent ( $8 \%$ for coalitions, requirement waived for national minorities). Furthermore, the Polish government changed the number of constituencies from 52 to 41 . The Polish Senate has 100 members elected by simple majority vote for a four-year term (IFES Election Guide - Poland 2008, 1; IPU 2008, 1; Shvetsova 1999, 401; Millard 2003, 70).

The Czech Republic made a decision to continue using a PR electoral system after the dissolution of Czechoslovakia. In addition, the country's parliamentary jurisdiction decided to favor a bicameral assembly - a parliament that is composed of a Senate with 81 members, elected for a six-year term in single seat constituencies by absolute majority vote. Furthermore, the Czech National Council, renamed the Chamber of Deputies, has 200 members, elected for a four-year term by proportional representation with a 5 percent legal threshold (IFES Election Guide - Czech Republic 2008, 1; IPU 2008, 1). The establishment of a PR electoral system in the Czech Republic resulted in the proliferation of political parties and movements. For example, in 1990 elections, 66 political parties, with no organizational structure or mass membership, entered the electoral competition (Wightman 1995, 240). 
Hungary, on the other hand, decided to adopt a mixed electoral system that represented a combination of PR and majoritarian electoral system. Hungary established a unicameral National Assembly, with 176 members elected in SMDs by majority of votes in two-round voting and 210 members elected in 20 territorial multi-member districts through proportional representation. As in the case of Poland, the legal threshold in the Hungarian PR tier increased from 4 percent in 1990 to 5 percent in 1994 (IFES Election Guide - Hungary 2008, 1; IPU 2008, 1, Shvetsova 1999, 400).

After the break up of communist rule, Russia adopted a mixed electoral system with a 5 percent threshold aimed to prevent proliferation of small parties. The plurality part of Russian elections surprisingly created more representation of small parties than the PR part and although it was expected that it would produce two-party competition; this did not happen due to low party identification and weak institutionalized party system. Currently, Russia's Federal Assembly is comprised of State Duma with 450 members elected in one nationwide constituency through proportional representation and Council of the Federation with 178 members elected in 89 multi-member ( 2 seats) districts. (IFES Election Guide - Russia 2008, 1; IPU 2008, 1).

The latest rounds of parliamentary elections and political developments in Central European countries are proof that the electoral systems in the post-communist countries are still transforming. In the Czech Republic, the 2006 parliamentary election resulted in a political crisis since the winning coalition was unable to form the government and secure support of the majority of deputies. Consequently, these problems may possibly lead to electoral reform (Plecitá - Vlachová and Stegmaier 2008, 179-184). Furthermore, many political parties in the post-communist states made an effort to manipulate electoral 
laws to produce more favorable electoral results like in Poland and Lithuania (Millard 2003, 69; Clark and Martinaitis 2008, 1). As a result, changes in electoral systems have major implications on party development in Central Europe.

\section{Slovak Electoral System}

After the fall of communism there was a great desire among political leaders in Czechoslovakia to establish new electoral legislation, to organize the first democratic elections, and to make some necessary adjustments in government. The new democratic leadership in Czechoslovakia decided to adopt a PR system that was used during pre-war period and in the last free elections in 1946. The decision to use this system was also intended to achieve greater proportionality, better minority representation, and to better accommodate individual personalities in the electoral system. The Czechoslovak PR electoral system had a 5 percent minimal legal threshold, which was required for political parties in order to enter the Federal Assembly and the Czech National Council, and a 3 percent legal threshold for the Slovak parliament. The number of seats elected for the Czech National Council was 200 and for the Slovak National Council - 150 (Shvetsova 1999, 400-401). By 1993, when Slovakia became an independent country, the country's government decided to stay with a PR electoral system. Slovakia adopted a list PR that involves each party presenting a list of candidates to the electorate, where voters opt for a party, and parties receive seats in proportion to their overall share of the national vote. Winning candidates are then taken from the party lists.

According to the first electoral law of independent Slovakia (80/1990), the country has a one-chamber parliament. The legislative body of the Slovak Republic is the 
National Council (Národna Rada), which passes legislation and shares with the government (Vláda) the right to initiate laws. The National Council has 150 members who are directly elected for four years through a system of proportional representation (IFES Election Guide - Slovakia 2008, 1; IPU 2008, 1). For administrative purposes, Slovakia is divided into 8 regions and 79 districts, where the highest administrative officials are appointed by the government.

In May 1998, “the Parliament adopted the law 187/1998 amending law 80/1990 on parliamentary elections" in the Slovak Republic (Cibulka 1998, 1). The major changes this amendment brought were made in the system of constituencies; i.e., this is an example of the effect of district magnitude. Based on the ratification of the new law, Slovakia's four single electoral constituencies were fused into one. According to Lubor Cibulka, this change is preferable for major political parties with strong leaders, and for the general organization of elections, however it is a disadvantage for smaller parties and parties that lack strong leaders because it decreases the connection between the candidate and the voters $(1998,1-3)$.

In order to participate in elections a political party must have a minimum of 10,000 members. If this requirement is not met, a party can still participate by filing a petition with signatures equal to the number of remaining candidates. However, these criteria do not affect those political parties that were in the parliament 60 days before the announcement of the election date or those parties that fulfilled the minimum membership requirement in the previous elections. The electoral threshold is 5 percent of the votes cast for individual parties (Sigma 1995, 2). Parties that fail to meet this requirement are eliminated from further election proceedings. 
The modification of the electoral formula in 1997 was a significant event in Slovak electoral politics, as it would be in any country. This was the result of the following events: The ruling Movement for a Democratic Slovakia (Hnutie za Demokratické Slovensko - HZDS) first decided to amend the election law to create legislative obstacles to prevent potential victory for the opposition (Mesežnikov 1999, 41). Changing the PR electoral system to a majoritarian or possibly mixed electoral system would not only considerably affect party formation in Slovakia, but it would also facilitate a victory for the $H Z D S$ in up-coming elections. This was clear to all political parties and consequently all of them opposed this radical proposed change in the electoral system; as a result, $H Z D S$ 's proposal failed.

In 1997, prior to the expiration of President Kováć's term, there was another important moment that took place in Slovak electoral history (March 1998). The opposition was afraid that since the parliament was responsible for electing a new president, and Vladimír Mečiar, both a leader of $H Z D S$ and prime minister at that time, was not willing to approve any choice of president the opposition was proposing, the situation could have resulted in a political crisis. Accordingly, the opposition decided to push forward certain changes in presidential elections. The opposition initiated an amendment to the constitution on direct presidential elections.

Although this amendment, also called the referendum on direct presidential elections, was rejected by Mečiar and his supporters, the situation strengthened cooperation among opposition parties and resulted in the establishment of the Slovak Democratic Coalition (Slovenská Demokratická Koalícia - SDK). HZDS, afraid of losing the up-coming 1998 parliamentary election, decided to make a different amendment to 
the electoral law. With the creation of the $S D K$, the idea of changing the electoral system from PR to majoritarian or mixed electoral system was not an issue any longer, and it would not ensure $H Z D S$ 's victory. Therefore, $H Z D S$ came up with a new idea to modify the electoral threshold to 5 percent for each individual party in a coalition (Mesežnikov 1999, 40-41). As a result of this electoral amendment, many small parties merged or ceased to exist.

\section{Party Formation}

Maurice Duverger's Political Parties is one of the most important works in electoral studies. He formulated what we call today "Duverger's Law", which asserts that the plurality system (in single-member districts) favors a two-party system $(1955,217)$. In order to explain how some electoral rules reduce the number of political parties, Duverger uses the term "mechanical effect". According to the "mechanical effect", some electoral rules assign extra seats to the larger political parties and as a result disadvantage smaller political parties, giving them fewer seats based on proportional representation. The "mechanical effect" which can occur in a single election can ultimately turn into a "psychological effect" in the next election. The "mechanical effect" that caused the under-representation of small parties ends up in fewer voters' supporting these parties in the next elections. It is the "psychological effect" in play that causes those people who previously voted for a political party to possibly stop supporting the same party assuming their vote would be in vain. Thus, the relationship between the "mechanical" and "psychological" effect decreases the number of assembly parties (Taagepera and Shugart $1989,65)$. 
Given the fact that electoral systems vary and they each have a different impact on political parties, we need to examine how the parties evolve. As will be seen, the literature suggests that party formation in Central Europe is different than elsewhere. In Making Votes Count, Gary Cox points out that social cleavages are important $(1997,19)$. Furthermore, Dieter Nohlen argues that the nature of the electoral system and the number of political parties are both affected by the number of social cleavages $(1993,27)$.

In Rethinking Party Systems: The Third Way of Democratization, Scott Mainwaring emphasizes a profound role of political parties in political transition. $\mathrm{He}$ argues that political parties are not only key delegates of representation, but they enable policy making as well. Furthermore, political parties are essential for creating a legitimate democratic system (1999, 11-14). Mainwaring suggests that the party system is institutionalized when "actors develop expectations and behavior based on the premise that the fundamental contours and rules of party competition and behavior will prevail into the foreseeable future" $(1999,25)$. Furthermore, party institutionalization is a complex process that includes electoral, social, attitudinal and organizational dimensions of party life. Mainwaring differentiates between more and less institutionalized party systems. He argues that in more institutionalized party systems political parties have deep roots in society, party organization is important, political figures make parties legitimate and party systems are much more stable. However, Mainwaring points out that this is not the case of the post-communist states where party roots are weak, parties lack organizational and ideological unity, and "personalism" plays an important role in these party systems $(1999,21-60)$. 
Cox argues that "different electoral systems produce different party systems" $(1997,23)$. Furthermore, Cox notes that strategic voting and strategic coordination play an important role in electoral politics and party formation. In her study of party strategies and voter behavior in Central European mixed electoral systems, Tatiana Kostadinova points out that political parties as well as voters act strategically in the elections. In addition, many political parties "form coalitions based on assessments of the magnitude and the distribution of their electoral support" $(2006,131)$.

The sequence of founding elections has been a major determinant of party formation in the post-communist states (McFaul 2001, 1159). First democratic elections held while a communist regime is still in power produced two polarized camps, one communist and the other anti-communist, that are very volatile and lack social bases. Czechoslovakia benefited from holding its first democratic elections soon after the fall of communism and, as a result, has had more developed political parties and more stable party systems.

As Kitschelt et al. point out, electoral contests for legislative office and the related establishment of electoral parties is one of the essential features of the democratic process $(1999,2)$. András Bozóki and John T. Ishiyama argue that the development of new political parties in Central Europe was largely influenced by the communist past and also by the evolving political landscapes. These legacies influenced communist successor parties in various ways. First, the communist past left diverse organizational consequences for the new political parties. While some political parties were better off in terms of inherited physical resources such as money, membership and buildings, other political parties were not. Furthermore, the communist regime also influenced the type of 
competitive environment facing new political parties. In addition, another heritage of the communist past was based upon who won out in the internal transition strife that occurred within each of the successor political parties $(2002,10)$.

\section{Party Formation in the Post-Communist Countries}

The post-communist countries of Central Europe and the former Soviet Union had many similar features in party formation, but also differences that were specific to the country's development and which differentiated these countries from one another.

Von Beyme characterizes party formation in the post-communist countries of Central Europe and the former Soviet Union by the following models: first, after the transition from communist rule, some countries tried to restore the electoral and party system that was used in the pre-communist period. This redevelopment was evident in the cases of East Germany and Czechoslovakia, but because of the long period of totalitarian rule, many countries could not follow this example, as they did not have any memory or extensive experience of a democratic party system $(1998,4)$. The "historical parties" which were able to redevelop failed in the post-communist era. The reasons were as follows: Communism systematically eliminated loyalty to political party, ownership, income and status. Therefore, "historical parties" were only able to attract voters whose allegiances were dependent on factors the communist regime was unable to eliminate. Another factor that caused the failure of historical parties was their long absence from the politics of these states. Although the pre-communist political parties had an important role in pre-war politics, the pressure from the Soviets ultimately established one-party rule that eliminated multiparty systems in these countries. The third factor was the 
devastating and complete control of society. In addition, some of the "historical parties" were tainted by Fascism during the interwar period (Wightman 1995, 241-243).

As discussed by Von Beyme, the second model of party formation in Central Europe was the establishment of a new system of political parties that was, in fact, most common for all post-communist countries $(1998,4)$. Another typical feature of party system development in the post-communist countries was the emergence of many new political parties that led post-communist countries to the democratic path and then disappeared within a few years after the transition. After the end of communist rule, many diverse political parties and movements were established that represented very broadly based, ideologically diffused and loosely organized social movements, which dominated the political scene without any significant competition in the first years of the transition. These opposition movements, such as Civic Forum in the Czech Republic or Public Against Violence in Slovakia, were among the political parties that quickly dropped from the post-communist political scene.

The period after transition was also a transforming time for many communist parties in the region. Former ruling communist parties understood that in order to remain active in politics they needed to adjust to new democratic rules. Some communist parties changed their names, or re-organized themselves into different political parties, in order not to remind people of their former past. Other communist parties, such as the one in the Czech Republic - the Communist Party of Bohemia and Moravia - refused to follow this example and retained their original name. Overall, former communist parties created new and more moderate reform policies that were aimed to ensure winning most of their voters back. However, the communist parties were not in a favorable position in the post- 
transition period due to the fact that there was widespread aversion towards communism, especially during the first years after the transition. This aversion was supported not only by post-communist political parties, alliances or unions, but it was in the minds of majority of the population in these countries (Wightman 1995, 241-251).

The first phase of party formation in the post-communist countries was the most important time for these states. At this stage, elections were held with multi-party representation, which resulted in a rapid proliferation of political parties of all types. Free and democratic elections with a high party representation were definitely successful for many post-communist nations. But unfortunately, countries such as Romania and Bulgaria were not able to achieve this goal at the same time as other countries in transition; in their first multi-party elections, ex-communist parties were able to win elections and take over new post-transition governments.

Also, there were the diverse effects that electoral systems had on party formation in the post-communist countries. Hungary and Russia had adopted the mixed electoral system, but its effect on the formation of a multi-party system was different from the beginning. In Hungary, the mixed electoral system with 5 percent threshold in the PR tier brought a low level of disproportionality and relative stability to the country's party system. Although Russia had also adopted a 5 percent threshold in its PR tier, which was supposed to prevent proliferation of small political parties, the results were quite the contrary. The plurality part of the Russian party system, instead of two-party competition, produced higher proliferation of small political parties than the PR part of electoral system. Therefore a high level of disproportionality in the party system occurred in Russia (Moser 1999, 372). 
Although, Czechoslovakia, Hungary, and Poland were among those postcommunist countries that were successful in their first round of elections, several problems still existed: building-up a new party system, party representation, and dealing with the proliferation of political parties. As George Wightman points out, by the late eighties and early nineties, there were 66 parties registered in Czechoslovakia, in excess of 100 parties in Poland, and approximately 65 in Hungary $(1995,240)$. The transformation process and party development in these states is still not complete. Although some countries like Hungary and the Czech Republic achieved relative stability of their party systems, the future rounds of parliamentary elections in these countries will determine whether the consolidation of party systems has occurred in the post-communist countries or not.

\section{Slovak Parties}

During the Stalinist era, several historical political parties that were active in Czechoslovakia during the interwar period, such as the People's Party, were forbidden after World War II. Other political parties, for example the Democratic Party, which was very active during 1945-1948, were eliminated after 1948. The formation of political parties and interest groups was also influenced by the reform period of 1968. The 1968 reforms and their consequent repression by the Soviet leadership had a great influence on political life in Czechoslovakia. However, the major changes occurred mainly in 1987, once Gustav Husák was replaced by Miloš Jakeš, and after the Soviet leader Mikhail Gorbachev began implementing his new policies of glasnost and perestroika. As a result, there was a dramatic increase in political participation among groups of people who were 
not previously politically active, especially young people. Consequently, wide support for democratization spread across the country and eventually contributed to the abolishment of the Communist Party (Wolchik 1997, 203-209).

After the fall of communism in Czechoslovakia, many new political parties were formed in order to compete in the elections. The Communist Party of Czechoslovakia lost its role as a leading political party in the country, but by reforming its structure and agenda it remained active, although insignificant, in every election. After the 1990 election the communist party disappeared from the political scene and its former members founded the Party of the Democratic Left (Strana Democratickej Lavice - SDL). A new Communist Party of Slovakia (Komunistická Strana Slovenska - KSS) split from $S D L^{\prime}$ and was re-established in 1991 (Grzymala-Busse 2002, 51-66; Rybář and DeeganKrause 2008, 1).

The Slovak people proved to be supportive of democratization in the country, especially regarding the establishment of a market economy and creating a democratic political system. However, attitudes towards political parties were somewhat negative from the beginning. After the break up of the communist regime during the period of 1989-1991, one of the most important issues for the new democratic Czechoslovakia, besides choosing a new electoral system, was the formation of a new party system that would be able to sustain democracy. There were two main goals for a new party system in Czechoslovakia. First, the parties in the post-transition period had to be very different from the ideological and disciplined communist party, and second, to avoid a weak democratic system, the new party system had to present pragmatic and narrow choices to voters. 
The 1989 "Velvet Revolution" was not only the last element that caused the fall of the communist rule in this Central European country, but it was also a result of the great desire among people to end communism in the country and move towards democracy. With the help of two major political parties - Public Against Violence in Slovakia and Civic Forum in the Czech Republic, this goal was successfully achieved. At the same time however, a new tendency occurred, where new political parties began to form whose appeal was mainly aimed to the electorate within one of the two republics. This division also continued in the 1990 election, which was the first free and democratic election after the country's transition from the communist regime. The 1992 election was the last election of the former Czechoslovakia before the country's division. From all the political parties that were able to secure enough votes to enter the parliament, there was the Slovak National Party (which was the only party supporting separation from the Czech Republic) with 7.9 percent on one side, and most of the other political parties on the other side, favoring federalism (Wightman 1995, 66-67).

As was noted earlier, the common goal of ending communist rule, which unified the country after 1968, was no longer the crucial factor in the politics of Czechoslovakia. There were not only important cultural and economic differences between the Czech Republic and Slovakia, but also different approaches in party representation and political style. Thus, this had a rapid effect on the relationship between the two republics and resulted in the abolition of the federation with the "Velvet Divorce" in 1993. After 1993, with Czechoslovakia divided into the independent Czech and Slovak Republics, new distinctive party systems emerged in both states. 
The formation of parties in Slovakia was very much influenced by the general nature of the transformation process during these early years of independence. According to Mesežnikov, there were three significant factors that influenced party formation in Slovakia during 1996-1998 (1999, 38). First, the modernization of Slovak society and globalization caused changes in the country's socio-demographic and socio-cultural structure, and significant shifts in voters' preferences occurred as a result.

Second, the decreased fragmentation of political parties caused by the pre-election coalition strategies of the opposition parties was another factor that influenced party formation in Slovakia. This aspect was caused by efforts of the opposition to maintain the institutional framework of a democratic regime by disregarding the ideological differences between parties. In other words, five political parties with different ideologies and political strength formed the Slovak Democratic Coalition $(S D K)$ just to make sure that the ruling Movement for Democratic Slovakia would lose the 1998 parliamentary election. Although there were many prognoses that this kind of unnatural integration would not coexist for long, the effect of this strategy was successful and SDK was able to win the elections. The third effect on party formation in Slovakia was modification of electoral threshold to 5 percent for each individual party in a coalition, as a result of which many small parties merged or ceased to exist.

In comparison with the period before the breakup of Czechoslovakia, there were several political parties whose position remains unchanged even today. Since their establishment, they continue to play an important role in the political process and elections in Slovakia. They are the Christian Democratic Movement $(K D H)$, the Movement for a Democratic Slovakia (HZDS), the Slovak National Party (SNS), the Party 
of Hungarian Coalition $(S M K-M K P)$, the Party of the Democratic Left (SDL') and the Slovak Democratic Coalition (SDK).

By early 2002 progress in European Union integration became part of the intense contest of Slovak politics. Furthermore, mass attitudes have played a major role in the rise of democracy in Central European nations. They also continue to be significant to the success of new institutions and reforms linked with the process of European accession. As will be discussed in detail later, public opinion surveys prepared by the Statistical Office of the Slovak Republic illustrate that political preferences of voters are significant determinants that affect voters' attitudes towards the integration of Slovakia into the European Union. Therefore, there is an evident correlation between party preference and a party's position on European Union integration. This political rivalry could be seen mainly between pro-reform and opposition parties, specifically before and during the 2002 parliamentary elections. This election was very crucial for the future of the Slovak Republic. As the 1994 election represented a farewell to communism, and the 1998 election the end of Mečiar's leadership, the possibility of Slovakia joining the European Union became a major factor of the 2002 parliamentary election. The results of the 2002 Slovak parliamentary election determined that Slovakia would continue and actually conclude its integration process into the European Union.

Political parties play a profound role in influencing public attitudes towards the European Union. As Cichowski implies, party support shapes preferences regarding European Union integration $(2000,1244)$. Bielasiak points out that the voters often view political parties as representatives of a certain policy, while political parties in opposition are often seen as supporters of opposing views $(2002,1247)$. In Slovakia, supporters of 
democratic coalition parties, such as the Slovak Democratic and Christian Union $(S D K U ́), A N O$, Christian Democratic Movement $(K D H)$ and the Hungarian Coalition $(S M K)$ were also among the main supporters of European Union accession, while voters for opposition political parties such as Movement for a Democratic Slovakia (HZDS), Slovak National Party (SNS), True Slovak National Party (P SNS), Party of the Democratic Left $(S D L)$ and the Communist Party of Slovakia (KSS) illustrated significantly lower support for European Union enlargement (Statistical Office of the Slovak Republic 2002, 1). Therefore, political parties are crucial to Slovak membership in the European Union.

\section{Voting Behavior}

Following the collapse of communism in Central Europe, there was an extensive debate over the models of voting behavior in the post-communist countries and factors that influence voter choices. The purpose of this section is to answer the following questions: Is the voting behavior in Central Europe unique or similar to the voting behavior in western democracies? Are there any common factors affecting voting behavior in the post-communist countries?

\section{Review of Relevant Studies}

There is a significant and growing literature on the analysis of post-communist elections in Central Europe especially as concerns Poland, the Czech Republic, Hungary, and Slovakia. Additionally, there is a smaller number of studies that incorporate electoral analysis across the region. My purpose here in reviewing these studies is to extract a set 
of known indicators, which based on these studies are associated with political party preference.

Anthony Downs wrote one of the first studies on the economic analysis of voting behavior. By utilizing rational choice theory, Downs asserts that voters make rational choices for their personal self-interest. Consequently, voters opt for a political party or a candidate whose policies will provide them with the highest value in the future. According to the scholarly literature there are two approaches to economic voting: prospective and retrospective. In prospective voting those who go to polls make their preferences based on prospects of future outcomes, whereas in retrospective voting voters make choices based on their experience with previous economic performance or the economic record of the political party (Doyle and Fidrmuc 2003, 4).

Jan Fidrmuc provides an important contribution to the study of voting behavior in transitional states, especially in regards to the effect that economics has on political change in Central Europe. He states that voting in the post-communist states differs from elections in Western democratic countries. In his article "Economics of Voting in PostCommunist Countries", Fidrmuc asserts that voting results are based on voters' experience with economic reforms; voters who did not benefit from economic reforms tend to vote for parties on the left, while voters who profited from reforms are likely to vote for the parties on the right of the political spectrum. Fidrmuc analyzes the second and following elections after the fall of communism, since he believes that issues related to economic reforms did not play an important role in the first post-transitional election during which voters were rather excited about dramatic political change and not concerned with economic matters $(2000,199-207)$. 
Another important contribution to the analysis of post-communist political parties and voting behavior is work of Herbert Kitschelt, Zdenka Mansfeldova, Radoslav Markowski, and Gábor Tóka (1999). Based on their analysis of four post-communist states, the authors argue that parties' weak political structures and programs have a significant impact on voters' electoral choices and their participation in democratic elections. There are several other factors affecting post-communist voting preferences: high levels of party fragmentation, lack of programmatic structuring of political parties, lack of voters' party identification, as well as high volatility in voters' support over time. In addition, the authors recognize that a country's historical past has a strong effect on the post-transition process, viable party competition, and consequently on voting behavior in post-communist states.

According to the work of Klára Vlachová there are three main models of voting behavior: the sociological model, the party identification model, and the rational choice model:

- The sociological model is a radical or structural approach that concentrates on the voting behavior of social groups, mainly those organized based on age, religion and social class. By representing the interests of social groups, political parties establish a close relationship with such groups. The disadvantage of this model is that it does not take into consideration what effect values, attitudes, and opinions play on voting behavior.

- The party identification model is a socio-psychological approach to voting that views voting in terms of a voter's long-term relationship to a political party. From a sociological perspective, party identification could be the result of one of several factors: 
1) positive thoughts towards a favored political party, including feelings of loyalty, connection, and lesser evil; 2) negative reaction towards an opposition political party, such as disloyalty, resentment, and greatest evil; 3) assessments supporting the favored political party and discarding all other political parties; 4) political values and issue positions of the favored political party, for example social-economic values (left-right), values related to political procedures (liberalism-authoritarianism), or trust in politics. From a psychological point of view, voters could identify with a political party because of different reasons. As a result, a voter's party identification could be pragmatic, which is characteristic especially of the urban population, for example employees and managers working for larger corporations; symbolic, characteristic to rural populations with limited levels of education; and ideological, specific to people with high levels of education, organization membership and activity $(2001,484)$. While party identification is usually a long-term association between a voter and a political party, it could be weakened due to changes in values, a rise of new important political issues, or new events. Consequently, with a decreased party identification, there is a smaller chance that a voter will continue vote for the same political party.

- According to the rational choice model, which is based on the economic theory of voting behavior, voters first acquire information on the ideology of various political parties and their stand on politically salient issues. Then they select and vote for a political party, which comes the closest to represent their values, interests, and concerns $(2001,480-485)$.

Comparative post-communist research studies point out several other perspectives on voting behavior. Based on the first point of view, similar to western democracies, 
post-communist voting behavior is influenced by socio-economic variables. According to the second approach, scholars believe that the economic model of voting cannot fully explain voting behavior. In addition, the literature acknowledges that particular demographic variables are closely linked to voting, for example: education, income, and unemployment.

In a study of electoral behavior in the 1994 Hungarian election, András Kovács found that Hungarian voters behaved differently than the voters in Western democracies. Voters in Hungary were not likely to vote for political parties based on the parties' political and economic views; rather, they base their voting preferences by determining which political party is responsible for not resolving country's problems. Therefore, voters tend to vote for a political party that is best capable to dissociate itself from such responsibility. Another feature of Hungarian voting behavior is its inconsistency in loyalty. Furthermore, Kovács asserts that voting preferences in Hungary are "almost entirely determined by the positions and attitudes developed from the experience under communism of three and a half decades of "Kadarism"” (1996, 511-530). In contrast to other studies in the post-communist countries, Kovács asserts that voters' sociodemographic characteristics and their economic positions cannot be considered a steady indicator of voting behavior.

Similarly, Zoltan Kovács and Alan Dingsdale analyze voting behavior in the 1994 Hungarian parliamentary election. They affirm that Hungary displays distinctive geographic patterns in voting behavior. Taking into consideration voters' party

\footnotetext{
${ }^{2}$ Kadarism refers to leadership of János Kádár, the Hungarian communist leader who led the country from 1956 to 1988 .
} 
preference and voters' political awareness, Kovács and Dingsdale distinguish three main regions: a) Western Hungary and Budapest - an overall stable and politically more developed region with ideologically steady voting preferences and higher voter turnout, b) Eastern Hungary - a less developed, politically less motivated, and overall unstable region with major shifts in voters' preferences and typically low voter turnout, c) a mixed Central region - with some stable and other unstable districts in regards to party orientation. Furthermore, from an analysis of socio-demographic variables, Kovács and Dingsdale did not find a correlation between voting preferences and ethnicity, religion, or historical legacies. However, geographical analysis of electoral results confirmed the correlation between voting and the economic status of regions. Voters who were living in areas affected by the economic recession and disappearing socialist economy voted for the parties on the left of the political spectrum, while voters living in the prosperous regions voted for pro-reform political parties $(1998,456-457)$.

The analysis of post-communist Polish voting behavior is the focus of Tomasz Zarycki and Andrzej Nowak's study; they found that in regards to the urban-rural divide of the Polish political scene, the political character of the urban areas tends to be more liberal. Furthermore, there are significant differences in voting behavior in the rural areas. Zarycki and Nowak assert that there were important changes in political preferences of Polish voters between 1990 to 1997. According to Western standards this partisan volatility likely represented a total discontinuity of voters' political affiliation. There are several factors affecting political behavior in Poland. Institutional changes make voters alter their voting preferences to the new political system. As a result, voters act rationally by voting for a political party or a candidate that has a chance to receive sufficient 
number of votes in elections. The evolution of party organizations is another factor influencing Polish political behavior. There are often parties that cease to exist or merge with other political parties, parties that change their names or political programs, and new parties that form. These transformations of political parties consequently force voters to reconsider their political preferences. Furthermore, persistent changes in voters' attitudes cause variations in voting behavior. Voters change their perceptions and attitudes as a result of media and electoral campaigns. Zarycki and Nowak argue that between the 1991 Polish parliamentary election and the 1995 Polish presidential contest, voter turnout increased from $40.7 \%$ to $70.1 \%$. Their analysis revealed that the urban-rural divide was an important factor influencing such variance along with "historical roots of regional differentiation of voting preferences" (2000, 331-354).

In the study of voter turnout dynamics, Tatiana Kostadinova found a unique dimension that applies specifically to post-communist states of Eastern Europe. First, voter turnout is influenced by the electoral system that country adopts. Post-communist elections held under proportional representation systems tend to have higher turnout rates than under majoritarian systems. In addition, voter turnout in the first post-communist election is usually the highest and tends to decline in each consequent election. Furthermore, voter turnout is negatively affected by large number of political parties competing in election (2003, 754-755).

In the article "Past and Present in Transitional Voting: Electoral Choices in PostCommunist Poland", Jack Bielasiak and David Blunck suggest that voting behavior in post-communist countries is shaped by voters' political attitudes and their experiences during the communist regime. According to their analysis, there are three ways in which 
the pre-transition period impacts post-transitional electoral choices of Polish voters. First, organizational affiliations of former members of the Solidarity movement and the Communist Party influence voters' voting behavior in the post-transition period. Second, voters' positions on different transition-related political and economic issues shape voters' support for different political parties and provide a close link between past attitudes and present preferences. Such issues are decommunization, which relates to the role old elites play in the new political regime, and issues related to the marketization of the economy, including "the pace of reforms, the extent of state economic intervention, or the provision of a social safety net" $(2002,567)$. Lastly, economic voting, i.e. voters' evaluation of various economic concerns and their comparison of their economic condition in the communist period and the post-transition era, plays an important role in Polish voting behavior. As confirmed by a variety of public opinion polls, the country's economic conditions are directly linked to voters' electoral choices. Voters' present economic outlook often relates to their previous economic status, as well as future prospects. Voters tend to penalize those political parties they believe are responsible for economic hardship and reward those political parties that offer alternative economic reforms that provide them with benefits $(2002,563-585)$.

Goldie Shabad and Kazimierz M. Slomczynski affirm that while some scholars believe that the formation of political preferences and group interests occurred only after the fall of communism, they on the other hand confirmed that a combination of sociodemographic variables (education, gender, religion, age, population density, former membership in the Communist Party or the Solidarity Trade Union) has a steady effect on political identities in Poland $(1999,716)$. 
According to their research of voting behavior in Romania and Ukraine, Steven Roper and Florin Fesnic argue that the voter's party preference is directly correlated to the regional variable in both countries. The authors employed a dummy variable for regions of Romania and Ukraine. In addition, from a number of independent variables that could possibly affect voting behavior, such as historical legacy, ethnicity, levels of urbanization, education, and gross domestic product ${ }^{3}$, the historical legacy variable plays a key role in shaping voting behavior and social cleavages in these countries. For example, difference in voting in the Transylvania region of Romania is a result of the historical legacies of the region, where ethnic Hungarians live in the north and ethnic Germans live in the south $(2003,119-131)$. Roper and Fesnic assert that while some scholars believe that "the transition history fundamentally influences voters' perceptions of policies and institutions, they find that even long-term historical patterns influence post-communist voter choice" $(2003,129)$. This adds to statement made by Kitschelt et al. that the pre-communist past of Central European countries had an effect on the communist regimes in these states, which consequently has an impact on party cleavages.

Differences in urban-rural voting provide an important look into voting behavior as well. In his study of linkages between Russian voting behavior and social variables, Timothy Colton found that age, education, urban-rural factor, regional setting, and income were main factors that determined voters' political choices in Russian elections. In his analysis, Colton asserts that rural residents tend to support communists political parties, while urban residents are inclined to vote for reform political parties (Colton 2000, 101). Along these same lines, in their analysis of three Russian Duma elections,

\footnotetext{
${ }^{3}$ Real GDP per capita is computed on the basis of purchasing power parity in US dollars.
} 
Ralph Clem and Peter Craumer confirm the fact that the urban-rural variable is directly linked to voting for certain political parties. There are also fundamental socio-economic characteristics of voters that affect voting behavior in Russian regions. Particularly, the regions dominated by rural population are likely to vote for parties on the left - the antireform parties, while the urban regions are inclined to vote for pro-reform political parties. This is understandable since the rural residents, who are usually less educated, older, poorer, and employed in the lagging agricultural sector, are more likely to be affected by the effects of a worsening Russian economy, and they convey their dissatisfaction with the economic situation by voting for anti-reform political parties parties on the left. Urban residents on the other hand, who tend to be better educated, white collar, younger, high-income voters are more likely to support pro-reform political parties $(2000,478-479 ; 2002,2-3)$. In addition, there are significant urban-rural variations in voter turnout across Russia. The rural areas with comparatively more older voters or pensioners, mainly agricultural workers, who are less educated and less paid, and often dissatisfied, usually demonstrate a higher voter turnout and they usually vote for the parties on the left. More urbanized areas tend to display a lower voter turnout and they tend to vote for pro-reform political parties (Clem and Craumer 1997, 382; Clem and Craumer 2000, 480-481).

Clem and Craumer also analyzed the correlation between economic measures and voting behavior. In a study of the 2000 Russian presidential election they did not find a significant correlation between unemployment, inflation, change in industrial production, housing privatization and voting outcomes. The only economic variable that demonstrated some correlation to voting behavior was wages. According to Clem and 
Craumer's analysis, lower wages are related to political parties on the left, whereas higher wages are related to pro-reform political parties $(2000,478-478)$. Furthermore, Clem and Craumer assert that in addition to urban-rural variations in voting, there is also a regional aspect of voting behavior that they link to socio-economic and demographic characteristics of the population living in these regions. Both scholars agree that "a clear and remarkably stable electoral geography of Russia has emerged in the post-Soviet period" and that there is "a pronounced regionalization of voting behavior across Russia" $(1997,379-380)$.

Another contribution to the study of voting behavior in post-communist countries is the scholarly work of Marcus A.G. Harper who focuses on three transitional countries - Hungary, Bulgaria, and Lithuania. Harper analyses whether individual level voting in these countries is sociotropic or pocketbook. According to sociotropic voting, voters establish their electoral choices after taking into consideration a country's economic conditions. Pocketbook voting on the other hand means that voters make electoral choices based on an evaluation of their personal economic status. If their economic status deteriorated under the current ruling party they will unlikely support the same political party in the future election. In contrast, if voters believe that their economic situation improved, they will most probably give a vote to the same political party in the next election. Based on his analysis, Harper recognized that economic voting was evident in three assessed post-communist countries to some extent: however, its form differentiated from one political party to another. Moreover, Harper did not find sufficient evidence to determine whether sociotropic or pocketbook voting was evident in these countries. Furthermore, while some scholars established a correlation between voting preferences 
and unemployment at the district-level, Harper did not find a link between voting choices and unemployment at the individual level (2000, 1191-1227).

In her study of the Czech voting behavior, Klára Vlachová argues that since 1992 the Czech Republic witnessed a more steady voting behavior, which resulted in the stabilization of the party system. As confirmed by various assessments of voting behavior, a majority of Czech voters opted for the same political party in 1996 and 1998 elections. In addition, while the declared left-right political orientation plays an essential role when choosing between ideologically cohesive parties, the socio-economic values of the voter play a vital role when selecting from ideologically distant political parties. Voters of several political parties, for example the Civic Democratic Party (ODS) and the Communist Party of Bohemia and Moravia $(K S C M)$, demonstrate a stronger party identification, which has resulted in a more stable voting behavior from these voters. Consequently, the electoral behavior of voters who do not feel loyal to any of the political parties will probably be less stable overtime. Furthermore, ODS demonstrates a pragmatic party identification by representing voters who are younger, urban, well educated, while $K S C M$ is an example of a symbolic party identification with voters being older, rural, less educated (2001, 485-498).

In their article "Values and Electoral Decisions in the Czech Republic", Petr Matějů and Klára Vlachová concentrate on the effect political values and attitudes have on voting behavior in the Czech Republic. Both scholars assert that voters' social characteristics and their political values are directly correlated with voting choices. Matějů and Vlachová determine that there are three main dimensions of Czech politics: "a value-based left-right political orientation; a dimension of demands on the 
government; and a dimension of "anomie" $(1998,265)$. The feeling of anomie could be seen as a root of political apathy and/or protest, which results from voters' dissatisfaction and isolation from politics. In the case of the post-communist states, the feeling of anomie is linked to the collapse of the communist system that brought to people new personal freedoms and new levels of responsibility, to which it was hard to adjust. The collapse of the old system was also accompanied by the loss of a sense of social security. Ultimately, the feeling of anomie has a significant impact on voting behavior in the postcommunist countries $(1998,249-269)$.

In their analysis of the development of voting preferences during post-communist transition in the Czech Republic, Orla Doyle and Jan Fidrmuc assert that several socioeconomic variables, as for example education and age, as well as the ideological orientation of voters are likely to have a steady effect on voting preferences across the time. Furthermore, Doyle and Fidrmuc state that economic factors as for example unemployment, income, and employment status shape voting behavior in the later phases of the transition. They argue that voting behavior in the post-communist countries is unique and different from voting behavior in established democracies. Doyle and Fidrmuc offer the following explanations to support their argument. First, they point out that voting in developed countries is usually retrospective, however retrospective voting does not necessary apply to countries in transition since the majority of political parties are either newly formed or recently went through major transformations, therefore they cannot be assessed based on their previous economic policies. Second, the uncertainty

\footnotetext{
${ }^{4}$ Anomie is defined as: social instability resulting from a breakdown of standards and values or personal unrest, alienation, and uncertainty that comes from a lack of purpose or ideals.
} 
that the transition process brought along in the post-communist countries made voters insecure about the future effects of economic reforms and what costs and benefits the transition will bring to them. As a result, this uncertainty shapes voting behavior in the post-communist states. Moreover, the beginning of the transition process is a time of major economic turmoil, where stakes are extremely high for voters, therefore economic factors play a major role in voters' preferences $(2003,2-3)$. Also in this regard, Mathias Dewatripont and Gerard Roland point out that once voters obtain new information regarding the outcomes of economic reform they are likely to adjust their expectations and possibly alter their support for the economic reform. This adds to the argument of the scholarly literature that voting behavior and voters' electoral choices are likely to change during transition process $(1995,1207-1223)$.

In their analysis of the Czech voting behavior, Doyle and Fidrmuc found that socio-demographic characteristics of voters are linked to voters' electoral choices and have an impact on their voting behavior. They suggest that education and age shape voting preferences in the Czech Republic. Well-educated, younger voters tend to vote for pro-reform parties, as for example Civic Democratic Party $(O D S)$, since they are more likely to benefit from the transformation and they easier adjust to change. Whereas elderly, less educated voters, who were negatively affected by the process of transition, vote for the left-wing political parties such as Czech Social Democratic Party (ČSSD) and Communist Party $(K S \check{C} M)$, which are more likely to represent their interests and best assist them with the adjustment to a dramatic shock that transition brought along (2003, 10). This supports the argument made by Vlachová earlier on that voters' sociodemographic indicators are directly correlated with voting preferences. From an 
economic point of view, Doyle and Fidrmuc found signs of prospective voting among Czech voters. They confirmed, that from economic variables, unemployment is closely correlated with political parties on the left. Doyle and Fidrmuc furthermore assert that economic variables such as economic status and income are less likely to shape voting behavior in the early transition period, however they play a more significant role in the later phases of transition. (2003, 11-14).

In his analysis of voting behavior in post-communist countries, Fidrmuc utilizes a number of economic variables (wage, unemployment, employment) and sociodemographic variables (age, education, religion, and population density) that allows him to draw conclusions regarding their impact on voters' electoral choices. He indicates that wages are directly linked to vote for nationalist parties, whereas they are negatively correlated to voting for pro-reform parties. Unemployment on the other hand decreases the number of electoral votes for nationalist parties, while it increases support for political parties on the left of the political spectrum. A positive effect on the left-wing parties is understandable since unemployment was an adverse outcome of posttransitional economic reform, which affected voters in a negative way. Furthermore, entrepreneurs who represent the private sector tend to vote for pro-reform parties, whereas their support for nationalist and left wing parties is negatively correlated.

From socio-demographic indicators, Fidrmuc confirms an increase of electoral votes for pro-reform parties and insignificant support for nationalist and left-wing parties in urban areas. In addition, retired voters who were particularly affected by negative outcomes of economic reforms are likely to vote for nationalist and left-wing parties in Slovakia, Poland, and Hungary, while they tend to vote for pro-reform parties in the 
Czech Republic. In summary, "uneven distribution of benefits and costs of reform creates winners and losers, and thus constituencies supporting or opposing radical economic reform" $(2000,215)$.

Lars Johannsen also studies emerging urban-rural cleavages in transition states. He draws similar conclusions as other scholars of transition. According to his research, urban voters tend to vote for parties supporting market reform and a decreasing role of the government in welfare. While urban voters are more interested in political life, rural voters are the ones with the highest level of participation in voting. He argues that there are three main lessons to be learned from previous scholarly work on cleavage structures and political development. First, previous research confirms that economic and political transformation shapes voters' attitudes and public opinion on the role government in economic and social matters. Second, some scholars believe that post-transitional cleavage structure is historically embedded, while others argue that it is structurally rooted. The third lesson to be learned is that because political parties do not have close ties with voters, the political elites remain playing a crucial role in influencing the government and policies (2003, 297-307).

Geoffrey Evans and Stephen Whitefield study the structure of political cleavages in post-communist countries. Specifically, they analyze the effect that social and economic issues have on voting behavior and ideological orientation of political parties in the Czech and the Slovak Republics. Evans and Whitefield argue that there are diverse issue cleavages shaping voters' electoral choices in both countries - specifically the subject of ethnic rights of the Hungarian minority in the Slovak Republic, which resulted in more intense political conflict, and questions of market economy and voters' attitudes 
towards the West in the Czech Republic (1998, 115-139). Stephen Whitefield separately argues that voters did not lose the ability to have structured and multifaceted attitudes during the communist regime. In addition, voters were able to formulate opinions about how their attitudes relate to political parties and their programs (Whitefield 2002, 181200).

In another study of the Czech Republic, Orla Doyle and Patrick Paul Walsh found evidence of significant regional patterns in voting for pre-reform parties and parties on the left of the political spectrum throughout the country's transition from communism. Doyle and Walsh assert that there are two clear voting patterns observed in the Czech Republic: instability within smaller and center-left parties and stability within communist and pro-reform political parties. While scholars agree that the economic voting characteristic of Western democracies tend to be retrospective, Doyle and Walsh did not find indications of retrospective voting in the Czech Republic. Their analysis confirms that voting behavior in the first Czech election after the fall of communism as well as in other countries in transition was prospective instead. Because the majority of political parties, except the Communist Party, did not exist since the Second World War, voters were unable to form their political views on a variety of issues based on their past experiences. Instead, voters had to evaluate how economic issues, such as the establishment of a new market economy, will affect them in the future, and based on their predictions they consequently formed their voting preferences $(2005,25-27)$.

Socio-economic and demographic factors play a role as key determinants of voting behavior in post-communist states. Doyle and Walsh use the following socioeconomic and demographic indicators to determine voting patterns in the Czech 
Republic: the unemployment rate, average wages, the number of entrepreneurs, employment in agriculture vs. industry, higher education, roman-catholicism, population density, and the number of retirees. Doyle and Walsh found that regions with welleducated voters display a higher support for pro-reform political parties. In addition, there is a positive correlation between regions with a high percentage of roman-catholic voters and private entrepreneurs and pro-reform parties. According to their analysis, voters living in predominantly agricultural regions tend to vote for the parties on the left (communists) or the center-left (social democrats). Doyle and Walsh moreover point out that average regional wages do not have a significant effect on voting behavior in the Czech Republic. Based on their assessment, Doyle and Walsh found that voting for the pro-reform parties is negatively correlated with the unemployment rate, whereas support for the communists and other parties is positively correlated with the unemployment rate $(2005,8-25)$.

The majority of studies focused on economic voting in the transitional countries do not assess the first post-communist election since they believe that this particular founding election was simply a choice between communism and democracy, therefore theories of economic voting are not relevant in this case. In contrast, Doyle and Walsh confirm that although regional economic issues, which were a direct consequence of the economic reforms, impacted voting preferences in the second and all subsequent elections, these voting $(2005,6)$.

During the subsequent elections in the Czech Republic, voters' preferences and positions on economic reform and issues started changing since voters became more politically aware, experienced, sophisticated and essentially better educated about how 
the electoral process works. Voters learned that if they vote for an extreme or small party, there is a small probability that such a party will gain seats in the parliament and consequently that their interests will not have an advocate in the government. Therefore, their best chance for representation is to vote for a political party that has good prospects of receiving a sufficient number of voters to enter the parliament $(2005,10)$.

The post-communist transition process brought along challenges and adversity which resulted in a prevalent discontent among voters and provided a competitive edge to those political parties which proclaimed that they have fast and simple solutions to solve this situation. In addition, communist parties have taken advantage of voters' dissatisfaction with the economic reforms and consequently reestablished themselves in the political arena to appeal to voters predominantly impacted by the transition process (Jasiewicz 1998, 186). As a result of the abrasive economic conditions in the postcommunist countries, voters are likely to vote for those political parties that promise social and financial safety in the future.

By utilizing the cases of Slovakia and the Czech Republic, Kevin Deegan Krausse evaluates voters' political opinions and their effect on voting choices and consequently on the stability of the democratic system. According to his analysis, there is a difference between Czech and Slovak voters in terms of the issues voters focus on when assessing political parties. While in the Slovak Republic, voters analyze parties based on issues of democracy and the nation, in the Czech Republic voters focus on socio-economic questions instead. Krausse uses three models to analyze the relationship between voters' opinions and voting outcomes: left-right model, the factor model, and the spatial model. According to the first approach, the left-right orientation is more evident within the 
individual parties in Slovakia, whereas it is apparent at the party level in the Czech Republic. The factor approach assesses voters' positions on particular issues such as religion, economy, and transformation. Krausse argues that the factor approach does not work in Slovakia's case, whereas it works well in case of the Czech Republic. Lastly, Krausse points out that the spatial model provides a synopsis of voters' electoral choices and consequently helps us better understand the correlation between the preferences and issues $(2000,23-46)$.

In his book Regional Economic Voting: Russia, Poland, Hungary, Slovakia and the Czech Republic, 1990-1999, Joshua A. Tucker provides an impressive cross-regional analysis of the twenty parliamentary and presidential elections in the selected postcommunist countries. In his assessment, Tucker utilizes two types of factors - sociodemographic and economic cleavages, as well as new political developments that could have an impact on the range of support for a variety of political parties. From sociodemographic indicators Tucker uses the percentage of urban residents, population employed in agriculture vs. industry, percentage of elderly population, and size of the region, whereas from economic variables he employs wages, unemployment, and economic growth (2006, 78-125).

While some scholars utilize a model of retrospective voting, Tucker employs information-based model of voting instead. This approach depends on a forecast of how those voters who were most likely satisfied with the economic situation at the time of election will possibly vote in the new election (2006, 120-121).

Tucker presents two models of economic voting in post-communist states that foresee the impact of cross-regional difference in voting outcomes on the allocation of 
party votes - the Referendum Model and the Transitional Identity Model. "The Referendum Model produces the Incumbency hypothesis, which predicts that incumbent parties should perform better in areas of the country where economic conditions are stronger. The transitional Identity Model produces two hypotheses: the New Regime hypothesis, which predicts that parties closely associated with the transition away from communism ought to perform better in areas of the country where economic conditions are better; and the Old Regime hypothesis, which predicts that parties closely associated with the prior ruling communist parties ought to perform better in areas of the country where economic conditions are worse" $(2000,76)$. In his analysis Tucker affirms that that there is evidence that some political parties continually receive voters' support in regions that have more economic losers (Old Regime parties) while another group of political parties obtains a majority of votes in the regions that have more economic winners ( $\mathrm{New}$ Regime parties). While scholarly research on voting behavior in Western democracies asserts the significant role of rural-urban divide, center-periphery divide, labor patterns, and ethnic cleavages, the post-communist literature believes that pertinent socioeconomic cleavages have a key impact on voting behavior in the post-communist states.

In the beginning of this section we asked two questions: Is voting behavior in Central Europe unique or similar to the voting behavior in Western democracies? Are there any common factors affecting voting behavior in the post-communist countries?

We can conclude that there are three main differences between voting behavior in post-communist states and the Western democracies (Tucker 2006, 27-30). First, postcommunist elections tend to have a large number of competing political parties, specifically in the early stages of the transition, which is not typical for the established 
Western democracies. Second, voters have less knowledge about the parties. This is understandable since post-communist voters have less experience with electoral process and voters are unable to evaluate political parties based on their previous performance since many of them did not previously exist. Therefore, in contrast to voters in Western democracies, post-communist voters do not have strong attachments or identification with the political parties. Lastly, elections in post-communist countries occur during times of transition, which brings along positive as well as many negative effects and thus has a significant on voters' electoral choice and can lead to volatility in electoral outcomes.

Furthermore, there are features common to post-communist voting behavior. First, transitional scholars found evidence of correlations between socio-demographic variables and voting preferences in all post-transitional countries. Voters' electoral choices are shaped by socio-demographic variables, especially levels of education, age, and urban/rural residence. Thus, well-educated, young, urban voters tend to vote for proreform parties, whereas elderly, less educated, rural voters are more likely to vote for the left-wing parties. Secondly, from an economic point of view, post-communist studies found fairly consistent signs of prospective voting among transitional voters. Voters who did not benefit from economic reforms and who see little chance of improving their circumstances are likely to vote for parties on the left, while voters who profited from reforms tend to vote for the anti-reform parties. Lastly, scholars recognize that regional patterns of voting behavior emerged in the majority of transitional countries.

In summary, after the fall of communism in Central Europe, the selection of an electoral system had several profound implications on democratization in these countries, 
especially on the representation in competitive elections. Furthermore, party formation in the post-communist countries represented significant time for these states. For the first time, elections were held with multi-party representation, which produced a rapid proliferation of political parties of all types. The choice of an electoral system and changes in electoral rules played diverse effects on party formation in the postcommunist countries, including, as we have seen, Slovakia. Furthermore, socio-economic and demographic correlates of party or candidate preference have had an influence on the manner in which voting behavior evolves. In the next chapter, the socio-economic correlates of voting, as described in the literature cited above, will be operationalized with variables drawn from Slovak statistical and electoral data to test these propositions. In addition, as established in the literature, there have been important inter-regional differences in party and candidate competition within the Central European countries. Thus, the concept and reality of electoral geography is a subject of discussion of the next chapter. 


\section{CHAPTER III}

\section{ELECTORAL GEOGRAPHY AND DATA AND METHODS}

This chapter provides a review of the literature on electoral geography, the principal methodology used herein, and its two main approaches: place versus cleavage models. The second component of this chapter is a detailed discussion of the data and methods used in the study; the significance of the unique compilation of data is emphasized.

\section{Conceptualization of View on Electoral Geography}

As a branch of political geography, electoral geography examines the spatial dimension of elections. Electoral geographers have concerned themselves with the spatial organization of electoral areas, boundary definition, mapping election results, and explaining election results in terms of certain behavioral processes such as voting preferences and voter turnout.

\section{Place Approach}

David Reynolds claims that the study of electoral geography concentrates on one of the three topics: "the geography of voting, where the objective is to explain the spatial pattern of voting in terms of some other mapable characteristic(s); geographical influences on voting, where the object is to explain voting (typically the decision-making of individual voters) on the basis of 'spatial' contexts; and the geography of representation, which explores the means through which votes are converted into 'seats' in alternative electoral systems" $(1990,22)$. In addition, Archer and Shelly point out that 
there is another important topic discussed in the electoral geography literature "electoral dynamics and historical change in the geographies of elections" (1985, 11-28).

In Place and Politics: The Geographical Mediation of State and Society, John Agnew maintains that political behavior is primarily geographical and, therefore, the focus should be on place itself. He believes that "place-based political life" is a key factor affecting voter's decisions $(1987,6,41)$. Agnew further contends that the territorial (or sense of place) aspect has been established as a dimension in addition to social and political cleavages. In his other major scholarly work, Place and Politics in Modern Italy, Agnew uses the case of Italy to argue that "the geographical context of place channels the flow of interests, influence, and identities out of which emanate political activities such as organizing movements, joining parties, and voting" $(2002,26)$. By focusing on the notion of place, Agnew points out that the geographical perspective can provide a better insight into the changing dynamics of politics and society in Italy. Agnew also states that place plays a key role in shaping political outcomes. In his study, Agnew uses a number of different empirical methods to explain the geography of Italian political behavior, including large-scale quantitative studies, local analysis involving interviews and local written reports, as well as available testimonies of popular and elite political interests and identities. Agnew acknowledges that there are other views in current political thought that could be useful, but he asserts that a place-based approach is the most valuable concept to incorporate strengths of other theoretical perspectives and to best explain the role place plays in shaping political behavior (2002, 26-27). Furthermore, Agnew emphasizes four key themes in the study of place and politics. According to the first theme, "place is a topological space in which diverse geographical scales intersect 
through local and external networks to produce the milieus of everyday life in which people invest meaning as a source of their political identity... The second theme of historical contingency addresses the importance of putting places in a historical frame of reference... The third theme is that political action is not solely the result of the volition of autonomous individuals or the group memberships to which observers allocate them but that individuals never exist apart from the historical-geographic contexts of their lives... Finally, ...there is evidence... of an increasing disjuncture between the political spaces that are relevant to contemporary practical interests and identities and the statebased territories..." (2002, 219-220).

According to the literature on electoral geography, there are four main theories of place.

- The first is the theory of modernization-nationalization, which focuses "on 'neighborhood effects' (the effects of distance on information flows) and 'partisan cues' (information about parties) in order to explain electoral behavior" (Cox 1969, 96-100). Cox concludes that the nationalization of electoral behavior is a result of modernization (industrialization and urbanization).

- Demographic-welfare theory was introduced in the 1970s as an answer to the growing social issues and regional political movements in Europe and North America. Cox argues that political behavior can be characterized according to the "spatial distribution of social groups and their access to public goods and services" (Agnew 1990, 16). 
- $\quad$ The theory of uneven development, which also focuses on spatial aspects of political behavior. According to this view, the most significant reason for transformation is "the uneven economic development of the country in relation to long-cycles of the world economy and internal migration patterns" (Agnew 1990, 16-17).

- Micro-sociological theory of place is linked to the French school of social geography. In an analysis of the Scottish National Party (SNP) in Scotland, John Agnew claims that since all places have their own history and traditions, places provide the social framework in which political expression is established. $(1987,159)$

As Alexander Murphy argues, place plays an important role in electoral geography and the "ideology" of place significantly influences voting and the issues that are relevant to voters. The strategies for elections used by political parties and candidates are also affected by ideologies of place since political parties often study voting preferences in different regions with the goal of attracting voters in particular places. Murphy points out that the role of place in the political process is not only in terms of representing a spatial unit, but also in differentiating areas of socio-political identification (1990, 228-229). Murphy accentuates that the focus of electoral geography should be on the role of place in the geographical analysis of elections. Murphy demonstrates his model by examining the changes in electoral politics in Belgium and proving that these changes are place-based and not in accordance with Lipset and Rokkan's cleavage model $(1990,227-241)$. 


\section{Cleavage Model}

Lipset and Rokkan contend that there are four types of cleavages that voters and political parties tend to organize around: urban versus rural interests, territorial (center versus periphery), labor and capital (worker versus owner/employer), and functional (church versus state or various religious interests) (1967, 3-64). The Lipset-Rokkan model was mostly used in the study of Western democracies. For example, in the study of Irish parliamentary elections and referenda, John O'Loughlin and Anthony Parker confirmed that cleavages have been evident in the country's electoral politics for more than 80 years. Similar evidence was also found in the study of Dutch electoral politics examined by Nico Passchier and Herman van der Wusten (O’Loughlin and Parker 1990, 60-85).

Many electoral geography scholars believe that the original Lipset-Rokkan cleavage model cannot be applied to the study of elections in post-communist states. Herbert Kitschelt et al. assert that the Lipset-Rokkan model needs to be updated for discussion of politics of post-communist countries; accordingly, they introduced a new cleavage model that is better suited for the study of electoral politics in post-communist countries of Central Europe and the former Soviet Union. The model has two main dimensions: conflict between "national closure and cosmopolitan opening", and the conflict between "ethnic groups in socio-culturally divided societies" (1999: 64). Kitschelt et al. propose that there is another dimension evident in post-communist countries - the conflict between opposition and proponents of the communist regime.

As part of the last conflict, Kitschelt et al. characterize the following divides: $a$ political regime divide (results from people's status in the socio-political hierarchy, their 
economic stature, and the experience under the communist regime), an economic distributive divide (supporters of planned economy versus supporters of market economy), a socio-cultural divide (aligned with various economic choices), a nationalcosmopolitan divide (associated with economic preferences and concept of identity), and finally, an ethnic divide (defined by unevenness of ethnic groups) (1999, 64-69). Although the differences between Western and post-communist cleavages are emphasized, Kitschelt et al. believe that electoral politics in post-communist countries will ultimately resemble the politics of the more mature Western European democracies.

\section{Socio-Economic Factors}

Socio-economic or compositional factors are known to be associated with voting preferences in general. Scott Mainwaring avers that voting behavior and party preference in elections are affected by both social cleavages such as class, education, urban/rural structure, religion, ethnicity, and by political cleavages - political factors that shape the party system (1999: 1). Therefore, socio-economic characteristics of the electorate in the regions, such as education, age, work force, urbanization, and wages, provide valuable indications as to the determinants of electoral behavior. Furthermore, based on the example of Germany in the early 1930s, John O'Loughlin, Colin Flint, and Luc Anselin illustrated how regional differences in socio-economic structural factors and the way in which place influenced the impact of political transformation, demonstrate in large measure the geographical variation in voting for the Nazi party in the crucial election of $1930(1994,351-380)$. Moreover, there is a clear tendency of regional differentiation in voting in post-communist countries. Scholars emphasize the emergence of regional 
power bases for different political parties and coalitions as well as the manifestations of strong regional variations in various aspects of political behavior since democratization began in Central Europe. In their studies of regional political patterns of post-Soviet Russian politics, Ralph Clem and Peter Craumer emphasize that there is a strong correlation across the regions between the social and demographic composition of the population and their voting behavior $(1993,495)$. The areas that are predominantly younger, better educated, and urbanized incline to vote for pro-democratic parties and leaders, while areas that have a less educated, older population, living mainly in rural and agricultural regions express a lower level of confidence in pro-democratic parties and leaders.

In the article "Russia's Electoral Geography: A Review”, Ralph Clem asserts that according to a cleavage model individuals with similar socio-economic characteristics tend to vote similarly. Moreover, “...regional voting results derive primarily from the relative proportions of these classes in a given place" $(2006,384)$. Therefore, there is a correlation between voters' socio-economic structure and voting results. In their examination of the 1994 Hungarian parliamentary election, Kovacs and Dingsdale point out that "geographical patterns, while showing the stability of support for the main parties, also reveal the subtlety of voting transformations" $(1998,456)$. Based on their study of spatial differentiation that occurred in the Hungarian electorate, the country could be divided into three main regions with respect to party preference and the political awareness of the population. There are several other studies that further analyze the regional patterns of electoral behavior in the post-communist states. Jean Vanlaer (1991) successfully illustrates the main types of political regions in Central Europe classified 
from the point of view of electoral behavior, while Roger Bivand (1994) examines the regional variations of electoral behavior in Poland and Czechoslovakia. Ralph Clem and Marek Chodakiewics evaluate the spatial differences in the June 2003 EU Accession Referendum by testing the relationship between voting patterns and socio-demographic characteristics (2004). Furthermore, Peter Craumer and James Clem analyzed Ukraine's emerging electoral geography by examining the relationship between two elements of voting behavior - voter turnout and voters' preference - and socio-economic and demographic variables (1999, 1-26). Additionally, Joshua Tucker provides a comprehensive study of regional economic voting in Russia, Poland, Hungary, Slovakia, and the Czech Republic from 1990 to 1999 (2006). These studies confirm that there are evident regional variations in voting behavior across Central European states. In addition, the socio-economic characteristics of populations living in different regions seems to influence voting preferences in the elections.

In summary, the two main approaches of electoral geography: place versus cleavage models explain how geography shapes political behavior. The definition of place and the reasons why place is included in electoral politics has important implications on how the electoral process works. As Shelly et al. point out, "the mapping of voting statistics has provided important insights into the operation of modern polities" $(1990,1)$. Agnew's comprehensive analysis of Italian politics is a valuable contribution to the study of how place influences political behavior. Utilizing the cleavage model and using voters' socio-economic data could be a valuable indication of electoral behavior and geographical variations in voting as well. Agnew's use of different methodologies at successively larger scales is a challenging empirical task that is very difficult to put into 
practice. For the study of the Slovakia's electoral politics I will utilize a cleavage model, based mainly on socio-economic characteristics of the voting population. However, since we cannot exclusively rely on this approach, the analysis will also use reference to place when appropriate.

\section{Data and Methods}

The primary purpose of this study is to describe and explain the regional variations in voting behavior in post-communist Slovakia. Specifically, based on a case study of Slovakia, I examine how electoral support changed within various geographic regions during the country's ten years of democratic transformation. To do this, I have compiled a database of electoral results and socio-economic variables ordered into territorially comparable units, all of which are discussed below.

\section{The Setting for the Study}

The first ten years of the Slovakia's transformation, in which three national multiparty parliamentary elections were held $(1994,1998$, and 2002) provides an excellent opportunity to conduct a study on continuity and change in the country's electoral geography. Three broad questions are put to an empirical test:

(1) There is a tendency among voters in certain regions to provide continuous support to the same political parties/movements over time. 
(2) The socio-economic characteristics of the Slovak population (gender, age, education, religion, nationality, unemployment, work force distribution, wages, urban-rural variable, and population density) in different regions tend to influence voting preferences in the parliamentary elections.

(3) The survey studies suggest that there is an evident correlation between party preference and the party's position on integration into European Union, as measured by perceived attitudes regarding the benefits of EU membership.

\section{Challenges}

However, there are several data challenges involved in testing these propositions. Foremost is the need for a territorially comparable unit framework with electoral data and socio-economic data. Due to changes in the electoral constituencies, it was first necessary to organize the electoral data according to comparable territorial units. Additionally, there are no precise election data that would link voters' electoral support, within the Slovak regions, with the socio-economic characteristics of the voters. As I discuss below, public opinion surveys provide some individual level data that tie personal characteristics to political preferences and which will be used in tandem with the aggregate data deployed here, but polling results are subject to various errors and must be used with appropriate caution. Therefore, in my examination of how electoral support changed within various geographic regions of Slovakia during the country's ten years of democratic transformation, I take socio-economic data of the population within Slovak regions and link them with the election results by party in the individual regions. 
Furthermore, this study utilizes both aggregate and survey data. The advantage of using aggregate data is that such data use empirical facts, in this case the actual electoral votes cast. When using aggregate data, a common error occurring in the interpretation of shifts in party preference between elections, addressed by the political geography literature, is called the "ecological fallacy", which raises questions about imputing individual voting behavior from election results given in spatial units. This is a disadvantage when using aggregate data, and which necessitates cross-checking analytical outcomes with survey results.

So to mitigate this concern, in my later analysis I use public opinion polls and survey data since they provide additional sources of information on individual's voting preferences and voters' socio-economic characteristics. Through public opinion polls and surveys, voters express their views on political parties, which could help us explain regional variations in voting behavior. In addition, public opinion polls and surveys shape the way voters think about a country's political, economic, and cultural issues. In terms of European Union enlargement, the question this study examines is whether there is a correlation between voters' preferences of political parties and the way the public perceives political parties in the government, either as advocates of European Union membership or in a contrasting stance. The public opinion polls and survey studies help us test these important correlations over time. The disadvantage of using survey data is that they are not always accurate and reliable, since respondents may be untruthful or forgetful. Therefore, to bolster the analysis I use both aggregate and survey data to get the best possible results. 
A second concern is that the socio-economic data used in this study are not always consistent and they were not collected for the three particular years when the elections were held. Given that there are issues of territorial comparability, changes in political party lineup, and some misalignment of socio-economic data points with the elections, the following steps were taken to insure that the data base that forms the core of the later analysis is as consistent as possible.

\section{Unit Structure}

Administratively, Slovakia is divided into regions (kraj), which represent the largest sub-national units. The regions are then subdivided into districts (okres) and the districts are further divided into municipalities (obec). During the 1994 parliamentary election, the country was administratively divided into four regions, 38 districts, and 2,892 municipalities. However, as of August 24, 1996, the National Council of the Slovak Republic promulgated a new law in which the territory of Slovakia was officially divided into eight regions and 79 districts. Thus, the 1998 and 2002 election results are based on the same number of districts (79), but these differ from the units used in 1994. Therefore, in order to resolve the issue of territorial incomparability and make the electoral results for all three elections comparable, it was necessary to re-align the 1994 units thus:

First, the results of the 1994 parliamentary election at the municipality level, which were organized according in 38 districts, were reorganized based on 79 districts as in the 1998 and 2002 parliamentary elections, which will be the standardized unit structure employed in this study (Figure 1). 
Figure 1: District map of Slovakia

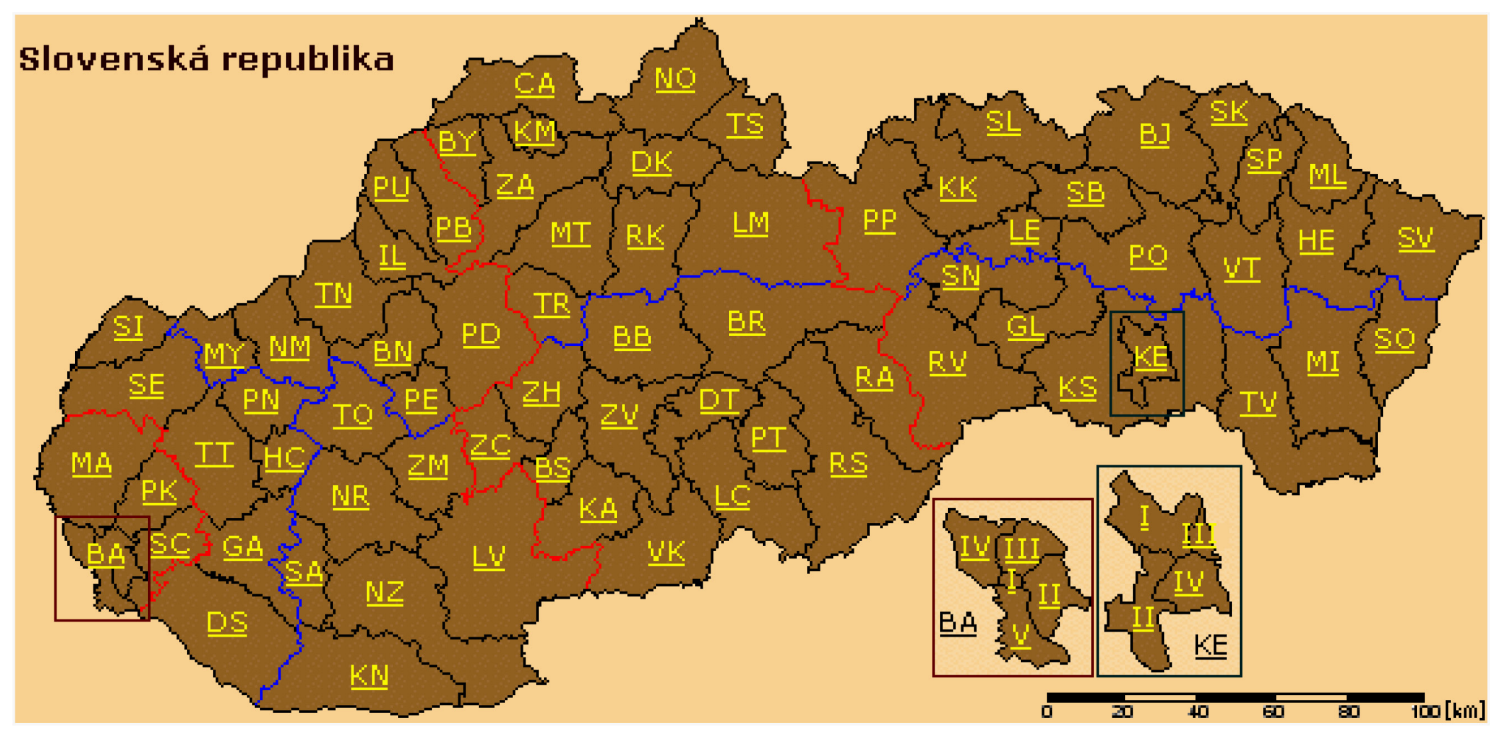

Source: Statistical Office of the Slovak Republic (2009). For key to the units go to:

http://portal.statistics.sk/mosmis/sk/run.html

Second, the lists of municipalities in the three elections were compared. The municipalities that were not included or the name of the municipality that did not appear in the exact format in all three sets of data, were determined and included in a separate spreadsheet. Third, to confirm whether the identified municipalities were correctly specified or if there were any disparities, the names of municipalities were cross-checked with an official document published by the Slovak government called "Review of administrative-territorial changes, changes in names of municipalities and changes in names of parts of municipalities approved during the period of July 1, 1993 until December 31, 2002” (Brestovanská 2002) ${ }^{5}$.

\footnotetext{
${ }^{5}$ http://www.civil.gov.sk/archiv/ovvs/obce_SR/prehlad.doc
} 
Fourth, after eliminating the highlighted municipalities that were not included in the sets of data for all three elections, changes were reviewed and the data were adjusted accordingly. If the data could not be adjusted, the identified municipality was eliminated from the data sets for all three elections and was not used for further analysis. Out of 2,892 municipalities, there were only 50 that were not included in the data, representing $1.7 \%$ of the total number of municipalities. Thus, the electoral data at the municipality level were compiled for 1994, 1998, and 2002 elections in territorially comparable units. Fifth, since the purpose of this study required the electoral data at the district level, the electoral results for all three elections were calculated by combining electoral results of municipalities.

\section{Election Results By Political Party}

In examining the results of the 1994, 1998, and 2002 elections in the Slovak Republic, I also use collected aggregate data in the form of official electoral results of political parties published by the Statistical Office of the Slovak Republic. The electoral data based on regions, districts as well as municipalities are available for all three elections.

There were 18 political parties competing in the 1994 contest, 17 parties participating in 1998, and 26 parties competing in 2002. Eight of the parties that were on the Slovak political scene since the first democratic parliamentary election in 1994 remained in the same exact form or with a slight modification in the 1998 and 2002 elections. From all new political parties established during the period of the three elections the most significant ones were the Party of Civic Understanding (SOP - Strana 
Občianskeho Porozumenia) founded in 1998 by Rudolf Schuster, a former mayor of the second largest city of Košice, who used it as a vehicle for his presidential ambitions; SMER established in 1999 by Robert Fico, who aimed to create space for the arrival of a new political generation in Slovakia; and the Alliance of the New Citizen (ANO) founded in April 2001 by Pavol Rusko, a former chairman of the largest Slovak private TV station.

In addition, there were several newly founded political parties established as a result of internal conflicts within their previous political parties. For example, the Party for Democracy (HZD - Hnutie za Demokraciu) was formed by former members of the HZDS, the Slovak Democratic Alliance was established by former politicians of the $S D L$, and the True Slovak National Party (P SNS - Pravá Slovenská Národná Strana) was created by former members of the original $S N S$. For a schematic representation of these party alignments, see Figure 2.

Furthermore, in each election there were many parties that did not meet the required 5 percent electoral threshold: 11 out of 18 in 1994 election, 11 out of 17 in 1998 election, and 18 out of 26 in 2002 election. Typically, these electoral parties received voter support below 2 percent: 8 in 1994, 10 in 1998, and 15 in 2002. This demonstrates a certain lack of rational behavior among leaders of such political parties who represented an agenda of a very narrow electorate and a consequence, many such political parties and movements ceased to exist as voters shifted their allegiance to parties that stood a better chance of actually receiving parliamentary seats via PR. Among such fleeting parties were the Party Against Corruption, for Order, Labor and Money for all Decent Citizens (SPK - Strana Proti Korupcii, za Poriadok, Prácu a Peniaze pre Všetkých Slušných 
Občanov), the Association for the Republic - Republicans (ZPR-REP - Združenie pre Republiku - Republikáni, and the United Party of Workers of Slovakia (JSPS - Jednotná Strana Pracujúcich Slovenska).

\section{Socio-Economic Data}

Socio-economic data for Slovakia's population at the municipality level are provided by the Statistical Office of the Slovak Republic and they are also partially available electronically at the website of the Statistical Office of the Slovak Republic, www.statistics.sk/mosmis/run.html. By comparing these socio-economic characteristics of the population with the election outcomes, we will be able to test propositions drawn from the literature on the determinants of voter behavior. 
Table 1: Winning political parties of 1994, 1998, and 2002 Slovak parliamentary elections 1994 Election 1998 Election 2002 Election

\begin{tabular}{|c|c|c|}
\hline$H Z D S$ / Movement for a & $H Z D S$ / Movement for a & $H Z D S$ / Movement for a Democratic \\
\hline Democratic Slovakia $(35.0 \%)$ & Democratic Slovakia $(27.0 \%)$ & Slovakia $(19.5 \%)$ \\
\hline $\begin{array}{l}Z R S \text { / Association of Workers } \\
\text { of Slovakia }(7.3 \%)\end{array}$ & $\begin{array}{l}\text { SOP / Party of Civic } \\
\text { Understanding }(8.0 \%)\end{array}$ & $\begin{array}{l}\text { KSS / Communist Party of Slovakia } \\
(6.3 \%)\end{array}$ \\
\hline $\begin{array}{l}\text { SNS / Slovak National Party } \\
(5.4 \%)\end{array}$ & $\begin{array}{l}\text { SNS / Slovak National Party } \\
(9.1 \%)\end{array}$ & $\begin{array}{l}A N O / \text { Alliance of the New Citizen } \\
(8.0 \%)\end{array}$ \\
\hline Spoločná Vol’ba / Common & $S D L$ / Party of Democratic & $\operatorname{SMER}(13.5 \%)$ \\
\hline Choice (10.4\%) & Left (14.7\%) & \\
\hline $\begin{array}{l}\text { Demokratická Únia / } \\
\text { Democratic Union (8.6\%) }\end{array}$ & $\begin{array}{l}S D K / \text { Slovak Democratic } \\
\text { Coalition }(26.3 \%)\end{array}$ & $\begin{array}{l}S D K U ́ \text { / Slovak Democratic Christian } \\
\text { Union }(15.1 \%)\end{array}$ \\
\hline $\begin{array}{l}K D H / \text { Christian Democratic } \\
\text { Movement }(10.1 \%)\end{array}$ & & $\begin{array}{l}K D H \text { / Christian Democratic } \\
\text { Movement }(8.3 \%)\end{array}$ \\
\hline $\begin{array}{l}M K / \text { Hungarian Coalition } \\
(10.2 \%)\end{array}$ & Hungarian Coalition $(9.1 \%)$ & $\begin{array}{l}S M K-M K P \text { / Party of Hungarian } \\
\text { Coalition }(11.2 \%)\end{array}$ \\
\hline
\end{tabular}


To illustrate the socio-economic structure of voters at the district level, the following variables are used: age structure, gender, unemployment, religion, nationality, work force distribution, wages, urban vs. rural structure, and population density. Each of these variables represents certain voter characteristics thought to be related to political performances and is defined as follows:

\section{$\underline{\text { Age Structure }}$}

This variable indicates the number of people living in a particular district in accordance to different age groups for the year 1996:

1. $18-24$

2. $25-34$

3. $35-44$

4. $45-54$

5. $55-59$

6. $60+$

\section{$\underline{\text { Gender }}$}

This variable provides the ratio of men and women living in specific districts. The data on sex ratio are available for 2001 at the district level.

\section{Unemployment}

This variable indicates the percentage of unemployment at the district level. The data are available for 2001 at the district level. 


\section{$\underline{\text { Religion }}$}

Four types of religious orientations are taken into consideration: Catholic, Evangelic, Atheist, and other. The statistics on religious orientation are available for 2001 at the district level.

\section{$\underline{\text { Nationality (Ethnicity) }}$}

For the purposes of this research study, four types of nationality are considered - Slovak, Hungarian, Roma, and other. The data on nationality are available for 2001 at the district level.

\section{Work Force Distribution}

The data are available for 2001 at the district level under eleven categories:

1. Industry

2. Construction Industry

3. Business

4. Hotels \& Restaurants

5. Transportation, Postal Services, Telecommunications

6. Finance

7. Real Estate

8. Public Sector

9. Education

10. Health \& Social Services

11. Other Services 


\section{$\underline{\text { Wages }}$}

This variable illustrates the average monthly wage, in Slovak Krones (SKK), of employees who worked for enterprises with 20 or more employees in the following areas of specialization for the year 2001:

1. Agriculture

2. Industry

3. Manufacturing

4. Construction

5. Trade

\section{Urban vs. Rural Structure}

The data on urban and rural populations are available for 2003 at the district level. This is the level of urbanization and is expressed as a percentage. According to law number $369 / 1990$, section 1, paragraph 22, city (urban area) is defined as municipality with 5,000 or more inhabitants.

\section{$\underline{\text { Population Density (in sq km) }}$}

The data are available for 1996 at the district level.

\section{Education}

This variable indicates the number of people living in a particular district having completed different education levels as of 2001: 


\section{Elementary education}

2. Secondary vocational with high school exam

3. Secondary professional without high school exam

4. Complete secondary vocational (with high school exam)

5. Complete vocational (with high school exam)

6. Complete secondary general

7. Higher education

\section{University education}

In summary, in this chapter we not only reviewed and emphasized the important contributions made to the literature on electoral geography, but also explained the two main models in electoral geography - place versus cleavage. Furthermore, the methodology of how the data were gathered and transformed, and how the data will be used, was described along with the challenges encountered during this process.

This dissertation builds on a pioneering work on Slovak elections published by the Slovak sociologist Vladimír Krivý, who has written a number of studies focused on voting and party preferences in the Slovak Republic. In his book What the Election Results Reveal: Parliamentary Election 1992-1998, Krivý illustrates a correlation between electoral results and one particular socio-demographic characteristic at a time: ethnicity, religion, education or the level of urbanization (1999).

While Krivý's research offers an important analysis of the Slovak parliamentary elections, this dissertation will be the first comprehensive longitudinal study of its kind. This study will use a combination of various socio-demographic variables (gender, age, education, nationality, religion, wage, and the level of urbanization) as they correlate to 
electoral results to gain a thorough understanding of their influence on voting behavior in different regions over time.

In addition, the study uses GIS software to map electoral results with sociodemographic data for all electoral districts. Since the comparable electoral data for 1994, 1998, and 2002 parliamentary elections were previously non-existent due to territorial incomparability, the newly acquired data is one of the main contributions of this study since the database of electoral results allow us to look at election results in comparable territorial units at the district level across time and helps us to better understand the socioeconomic correlates of voting across the Slovak regions. The compiled data also allows us to test proposed hypotheses. This data not only gives us the opportunity to better understand the Slovak electoral politics, but also represents a valuable and an important contribution to the field of electoral geography and provides an understanding of the transition process in the post-communist countries.

Finally, basic methods of data description and analysis is employed here to portray the spatial patterns of voting in Slovakia's elections and then to probe the relationships between the electoral results and the socio-economic variables across the country's 79 districts. Straightforward measures such as percentage distributions of party voting by unit and cross-tabulations of party voting with urbanization levels give us the first approximation of these relationships. Next, a set of bivariate correlations allows us test the propositions about the nexus between political preferences and given socioeconomic traits of the units' populations (e.g., between party voting and age) and suggests which among the several variables should be considered significant. Lastly, a multivariate regression analysis using the most promising variables provides us with a 
more complete picture of how and to what degree the relevant socio-economic characteristics explain variations in voting outcomes. 


\section{CHAPTER IV}

\section{VOTING RESULTS AND ANALYSIS OF REGIONAL VARIATIONS IN VOTING SUPPORT}

Any electoral geography analysis is based on the understanding that there are variations, at times significant variations, among regions of the country or countries in question with regard to the socio-economic structure of the population, and that these variations will to some degree be linked to the outcomes of elections because of the conceptual ties between those characteristics and the choices that voters make (essentially, the cleavage model). Thus, if, as we have seen above, individual level data point to a tendency for rural voters in post-communist countries to favor post-communist or populist parties and/or candidates, then we can hypothesize that areas that are relatively more rural will evince a higher than average vote share for those parties and/or candidates. Or to make the same point another way, if younger and better educated voters incline toward pro-reform parties, then it would follow that parts of a country where such people represent a higher than average share of the population would disproportionately support pro-reform parties and/or candidates.

It is universally the case that we find these kinds of spatial variations in socioeconomic conditions within countries because of differing regional natural resource endowment (for agriculture and/or industry), better or worse ties to internal or external markets (i.e., ports and lines of communication such as roads, rivers, and railroads), a well or less-well educated work force, differences in the availability of capital, and government regional development policies (this, of course, being especially true in centrally-planned economies). Regional variations may be more or less pronounced, may 
change over time as regions go through "boom or bust" cycles, and tend to be greater in larger countries, but even smaller states will have important differences in such socioeconomic measures as the level of urbanization, age structure of the population, levels of educational attainment, the sectoral distribution of the work force, unemployment rates, and wages or income. Finally, in multiethnic states we typically find different parts of the country with concentrations of one ethnic group or another; in fact, it is frequently the case that particular places are ethnic homelands, and are sometimes officially recognized as such.

Slovakia certainly conforms to the general case in this regard. As will be seen, although a small country in both area (roughly the size of Denmark) and population (around 5.5 million persons in 2009), one nevertheless finds relatively highly urbanized areas and also more rural, agricultural districts; modern, typically European cities (such as the capital, Bratislava), older industrial cities that have fallen on hard times and flourishing areas that have benefited from foreign investment and new industrial ventures; parts of the country with high unemployment and low wages and other regions with a much healthier economy; and significant differences from place to place in age structure and educational attainment. Further, Slovakia's substantial ethnic Hungarian minority is concentrated in districts adjoining Hungary to the south.

Bordering fellow European Union states from the Czech Republic in the west, Polandin the north, Hungary in the south, and Austria in the southwest, and with the former Soviet and non-EU Ukraine in the east, Slovakia is divided into eight official regions (Figure 2). 
Figure 2: Slovak regions

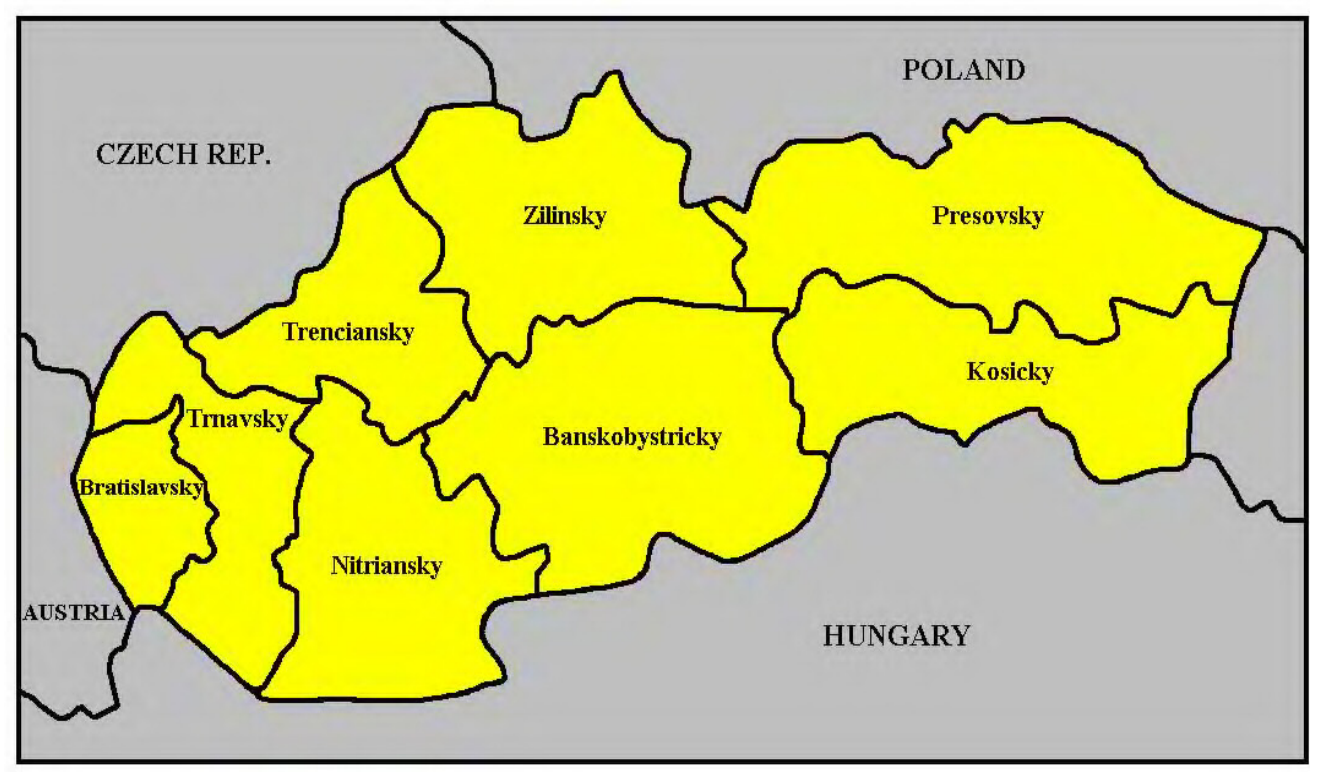

Source: Tatraview.com (2009). www.tatraview.com/geography.html. 
Table 2: Slovak regions - socio-economic characteristics of the population

\begin{tabular}{|c|c|c|c|c|c|c|c|c|c|}
\hline \multirow{2}{*}{ Region } & \multicolumn{2}{|c|}{ URBAN vs RURAL (2003) } & \multirow{2}{*}{$\begin{array}{l}\text { POPULATION } \\
\text { DENSITY in } \\
\text { Sq. km (1996) }\end{array}$} & \multicolumn{2}{|c|}{$\begin{array}{c}\text { GENDER (2001) } \\
\text { Permanently residing population }\end{array}$} & \multicolumn{3}{|c|}{$\begin{array}{l}\text { NATIONALITY (2001) } \\
\text { From permanently residing } \\
\text { population (in \%) }\end{array}$} & \multirow{2}{*}{$\begin{array}{l}\text { UNEMPLOYMENT } \\
\text { (in \%) } \\
\text { (2001) }\end{array}$} \\
\hline & $\begin{array}{c}\text { Rural } \\
\text { Population } \\
\%\end{array}$ & $\begin{array}{c}\text { Urban } \\
\text { Population } \\
\%\end{array}$ & & \multicolumn{2}{|c|}{ Permanently residing population } & Slovak & Hungarian & Roma & \\
\hline Bratislavský & 16.7 & 83.3 & 301 & 47.3 & 52.7 & 91.3 & 4.6 & 0.1 & 5.8 \\
\hline Trnavský & 50.5 & 49.5 & 132 & 48.7 & 51.3 & 73.9 & 23.7 & 0.6 & 15.5 \\
\hline Trenčiansky & 44.0 & 56.0 & 136 & 48.9 & 51.1 & 97.3 & 0.2 & 0.3 & 12.7 \\
\hline Nitriansky & 51.8 & 48.2 & 113 & 48.3 & 51.7 & 70.1 & 27.6 & 0.7 & 23.1 \\
\hline Žilinský & 49.7 & 50.3 & 101 & 49.1 & 50.9 & 97.5 & 0.1 & 0.4 & 16.4 \\
\hline Banskobystrický & 47.7 & 52.3 & 70 & 48.3 & 51.7 & 83.7 & 11.7 & 2.3 & 23.6 \\
\hline Prešovský & 53.2 & 46.8 & 86 & 49.2 & 50.8 & 90.7 & 0.1 & 4.0 & 24.0 \\
\hline Košický & 44.3 & 55.7 & 112 & 48.5 & 51.5 & 81.8 & 11.2 & 3.9 & 25.6 \\
\hline
\end{tabular}

\begin{tabular}{|c|c|c|c|c|c|c|c|c|c|c|c|}
\hline \multirow{2}{*}{ REGION } & \multicolumn{6}{|c|}{ AGE (1996) (in \%) } & \multicolumn{5}{|c|}{ EDUCATION (2001) (in \%) } \\
\hline & \begin{tabular}{|} 
Age Group \\
$18-24$
\end{tabular} & $\begin{array}{c}\text { Age Group } \\
25-34\end{array}$ & $\begin{array}{c}\text { Age Group } \\
35-44\end{array}$ & $\begin{array}{c}\text { Age Group } \\
45-54\end{array}$ & \begin{tabular}{|c} 
Age Group \\
$55-59$
\end{tabular} & $\begin{array}{c}\text { Age Group } \\
60+\end{array}$ & $\begin{array}{c}\text { Elementary } \\
\text { Education }\end{array}$ & $\begin{array}{c}\text { Complete } \\
\text { secondary } \\
\text { vocational } \\
\text { (with high } \\
\text { school } \\
\text { exam) }\end{array}$ & $\begin{array}{c}\text { Complete } \\
\text { vocational } \\
\text { (with high } \\
\text { school exam) }\end{array}$ & $\begin{array}{c}\text { Higher } \\
\text { Education }\end{array}$ & $\begin{array}{l}\text { University } \\
\text { Education }\end{array}$ \\
\hline Bratislavský & \begin{tabular}{ll|}
11.5 \\
\end{tabular} & 13.7 & 17.1 & 13.8 & 4.5 & 15.6 & 15.2 & 3.9 & 18.1 & 0.9 & $\mathbf{1 7 . 0}$ \\
\hline Trnavský & 12.4 & 14.2 & 15.5 & 12.4 & 4.6 & 15.1 & 22.9 & 4.5 & 14.4 & 0.4 & 6.0 \\
\hline Trenčiansky & 11.9 & 14.1 & 15.5 & 12.0 & 4.6 & 15.5 & 18.9 & 5.8 & 16.3 & 0.4 & 6.9 \\
\hline Nitriansky & \begin{tabular}{l|l}
11.7 \\
\end{tabular} & 13.9 & 15.4 & 12.3 & 4.8 & 17.0 & 24.8 & \begin{tabular}{l|l}
3.7 \\
\end{tabular} & 14.9 & 0.4 & 6.5 \\
\hline Žilinský & 12.3 & 14.3 & 15.1 & 11.4 & 4.2 & 14.5 & 20.0 & 5.3 & 15.3 & 0.5 & 6.9 \\
\hline Banskobystrický & 11.7 & 14.0 & 15.6 & 12.2 & 4.7 & 16.2 & 23.2 & 5.0 & 16.1 & 0.5 & 7.0 \\
\hline Prešovský & 12.3 & 14.4 & 14.5 & 10.5 & 4.0 & 13.6 & 21.8 & \begin{tabular}{l|l}
5.2 \\
\end{tabular} & 14.6 & 0.4 & 6.1 \\
\hline Košický & 12.1 & 14.2 & 15.3 & 11.6 & 4.4 & 14.4 & 20.9 & 4.1 & 16.4 & 0.5 & 7.5 \\
\hline
\end{tabular}




\begin{tabular}{|c|c|c|c|c|c|c|c|c|c|c|c|c|}
\hline \multirow[b]{2}{*}{ Region } & \multicolumn{12}{|c|}{ WORKFORCE DISTRIBUTION (2001) (in \%) } \\
\hline & $\begin{array}{l}\text { A griculture } \\
\text { \& Fishing }\end{array}$ & Industry & $\begin{array}{c}\text { Construction } \\
\text { Industry }\end{array}$ & Business & $\begin{array}{c}\text { Hotels \& } \\
\text { Restaurants }\end{array}$ & $\begin{array}{l}\text { Transportation, } \\
\text { Postal Services, } \\
\text { Telecomm. }\end{array}$ & Finance & $\begin{array}{c}\text { Real } \\
\text { Estate }\end{array}$ & $\begin{array}{l}\text { Public } \\
\text { Sector }\end{array}$ & Education & $\begin{array}{l}\text { Health \& } \\
\text { Social } \\
\text { Services }\end{array}$ & $\begin{array}{c}\text { Other } \\
\text { Services }\end{array}$ \\
\hline Bratislavský & 1.7 & 17.4 & 6.1 & 21.1 & 2.5 & 9.0 & 4.2 & 14.6 & 5.2 & 7.6 & 5.6 & 5.1 \\
\hline Trnavský & 8.7 & 29.2 & 8.0 & 17.3 & 1.9 & 6.0 & 1.0 & 6.4 & 3.4 & 8.5 & 6.3 & 3.4 \\
\hline Trenčiansky & 5.1 & 39.5 & 7.3 & 16.3 & 1.9 & 5.0 & 0.9 & 5.1 & 3.0 & 7.3 & 5.3 & 3.3 \\
\hline Nitriansky & 9.5 & 28.5 & 5.4 & 17.8 & 1.7 & 6.7 & 1.1 & 6.2 & 3.7 & 9.3 & 6.2 & 3.9 \\
\hline Zúlinský & 5.4 & 31.0 & 8.8 & 16.4 & 2.1 & 6.7 & 1.2 & 5.3 & 3.5 & 9.3 & 7.0 & 3.4 \\
\hline Banskobystrický & 8.1 & 29.5 & 4.8 & 15.1 & 2.0 & 7.3 & 1.3 & 5.6 & 4.4 & 10.2 & 7.5 & 4.1 \\
\hline Prešovský & 7.2 & 28.4 & 7.4 & 15.6 & 2.6 & 5.9 & 1.2 & 4.6 & 4.1 & 10.8 & 8.0 & 4.5 \\
\hline Košický & 5.3 & 25.9 & 5.4 & 16.4 & 1.9 & 10.1 & 1.3 & 7.9 & 3.9 & 10.0 & 7.3 & 4.7 \\
\hline
\end{tabular}

Source: Statistical Office of the Slovak Republic (1996, 2001, 2003). 
As is evident in Table 2, these regions have different socio-economic characteristics, and we can use them here to orient the later discussion of spatial patterns of voting preferences and the relationship between those outcomes and the socio-economic landscape; however, it is important to note that there is a considerably wider range of socio-economic indices among the 79 districts that comprise the data set than among the eight regions, where districts are grouped and inter-district differences muted.

Bratislavský region is located in the southeasternmost part of Slovakia and includes the capital Bratislava, the largest city in the country $(429,000$ in 2009), and has a relatively high population density (Table 2).This region has the highest percentage of urban population $(83.3 \%)$, the highest percentage of people with completed university degrees $(17.0 \%)$, the lowest rate of unemployment $(5.8 \%)$, and a high percentage of people claiming the Slovak nationality $(91.3 \%)$. The region's work force is mainly employed in business $(21.1 \%)$, industry $(17.4 \%)$, and in real estate $(14.6 \%)$. The Bratislavský region is also the base for chemical, textile, food, and automobile (Volkswagen Slovakia) industries. Furthermore, increased foreign investments have made this region the center of banking and trade.

Western Slovakia includes three regions - Trnavský, Trenčiansky, and Nitriansky. Trnavský region has a high percentage of Hungarian ethnic population (23.7\%) since its southern districts border with Hungary. The population is mainly employed in industry (29.2\%), especially in the automobile (Peugeot Citroen), food, and electro-technical industries. The majority of the population has completed either elementary $(22.9 \%)$ or high school education (14.4\%) and they live both in rural $(50.5 \%)$ and urban areas (49.5\%). 
Trenčiansky region, located in northwestern part of the country, is predominantly urban (56\%) with a moderate population density. The economically active population is primarily employed in industry (39.5\%), especially in textile, manufacturing, and food industries. In comparison to the national average (18.6\%), the unemployment rate in this region is below average (12.7\%) because the region has three large employers -the textile company Ozeta $\mathrm{Neo}$ and the electrical equipment production company Leoni Autokabel Slowakia located in the city of Trenčín and Hornonitrianske Bane, the largest producer of brown coal (used in thermal power plants) in Slovakia, located in the city of Prievidza.

Nitriansky region is slightly more rural $(51.8 \%)$. This region has the highest percentage of Hungarian nationality (27.6\%) because the southern districts are located along the border with Hungary. Compared to the national average, the Nitriansky region has a high level of unemployment (23.1\%) and a high percentage of population with only elementary education $(24.8 \%)$. The southern part of this region includes the city of Komárno, which has the largest port in Slovakia situated on the river Danube, and the city focuses on shipyard production. Furthermore, the region has a concentration of chemical, electro-technical, wood processing, food, and manufacturing industries.

Central Slovakia has two regions - Žilinský and Banskobystrický. Žilinský region, located in the north-central part of Slovakia has similar levels of urban (50.3\%) and rural $(49.7 \%)$ population. The majority of the economically active population is employed in industry (31.0\%) and business (16.4\%). The region is focused mainly on wood processing and paper industry. The latest addition to its industrial portfolio is the automotive industry with a plant for Kia Motors in the city of Žilina and Slovenský 
Vodohospodársky Podnik, which is in charge of water management for all of Slovakia. Due to its industrial growth, unemployment in the region has remained below the national average at $16.4 \%$.

Banskobystrický region, located in south-central Slovakia, is predominantly urban $(52.3 \%)$, however, the population density is only $70 \mathrm{sq} . \mathrm{km}$. This is a region with the third highest percentage of Hungarian nationals, again concentrated in the southern regions located along the Hungarian border. Historically, this area is rich in natural resources. During the communist period, this region was a center for heavy industry, especially for arms production. However, after the transition to a market economy, arms production was discontinued and the lack of new industries resulted in high levels of unemployment (23.6\%). Furthermore, it’s three districts - Revúca (35.1\%), Rimavská Sobota (35.5\%), and Vel'ký Krtíš (33.8\%) have the highest rates of unemployment in the country. A majority of the region's population has completed only elementary education $(23.2 \%)$ and most of them belong to the age category of 60 years or higher $(16.2 \%)$. While this region has wood processing, manufacturing, metallurgical, and food industries, most employment opportunities are available in the city of Banská Bystrica in the companies Lesy SR (wood processing) and Slovenská Pošta (Slovak Post Office) and in the closely located municipality of Podbrezová - in the company Železiarne Podbrezová (the oldest metallurgical company in Central Europe).

Finally, Eastern Slovakia has two regions - Prešovský and Košický.

Prešovský region is located in the northeastern part of the country and is mostly rural (53.2\%) with an average population density of $86 \mathrm{sq} . \mathrm{km}$. The region's urban population (46.8\%) is primarily concentrated in or around the city of Prešov, the third largest city of 
Slovakia (91,000 in 2009) and also in Poprad (55,000 in 2009). Prešovský region is characterized by a high unemployment rate (24.0\%) and the highest percentage of Roma population in the country $(4.0 \%)$ concentrated especially in the districts of Levoča $(7.1 \%)$ and Kežmarok (8.8\%). The education levels of the region's population are relatively low since a relatively high percentage of its residents have completed only elementary education $(21.8 \%)$ or high school education (14.6\%). While Prešovský region has wood processing, textile, and food industry on a smaller scale, this region does not have any major industrial parks and is known more for tourism thanks to the scenic Slovak mountains (High Tatras), with UNESCO historical/cultural sites such as Levoča and Spišská Nová Ves, and Slovak folk villages Važec and Východná.

Košický region, located in southeastern part of Slovakia, is considered more urban (55.7\%) since it includes the second largest city of Slovakia, Košice (241,000 in 2009. Because of its location and its proximity to the former Soviet Union and Poland, this region was once a center for processing of natural resources. Currently it has the largest metallurgical company in the country, U.S. Steel Košice, which is a dominant industrial center not just for this region, but also for the entire country. U.S. Steel Košice is also the biggest industrial employer in eastern Slovakia; as a consequence, $25.9 \%$ of the region's population is employed in industry. Ethnically, all major groups are represented - Slovaks with $81.8 \%$, Hungarians with $11.2 \%$, and Roma with $3.9 \%$. While the average unemployment rate for this region is $25.6 \%$, there are two districts that have among the highest unemployment rates in the country - Rožňava (32.0\%) and Trebišov (31.9\%). They are located in the southern part of the region along with the Hungarian border, in the area that lacks any major industries. 
In summary, Slovakia's regions and the districts that comprise them are defined by their economic status and the socio-demographic characteristics of their population. The largest cities like Bratislava and Košice are centers for foreign investments, banking, trade, and have a concentration of major industries, which provide sufficient employment opportunities to their residents. With the large number of universities and colleges located in both cities, their populations have the highest education levels in the country. In contrast, the economic status of other regions depends on the industries that are situated in the area. Apart from large-scale industries located in the city of Bratislava and Košice, small or medium scale industries are evident across Slovak regions. Such industries provide the majority of the employment opportunities in surrounding areas. Furthermore, in several regions there are districts that formerly had a strong industrial base during communism, but more recently these industries were discontinued and due to lack of investment they were never replaced by new production. As a result, these districts were suddenly left with no employment opportunities, which resulted in high levels of unemployment. As will be seen below, the character of Slovak regions and the districts within them and the socio-demographic features of their population played a major role in regional variation in voting support in the 1994, 1998, and 2002 Slovak parliamentary elections.

\section{Slovak Parliamentary Election: Regional Patterns}

The 1994 Slovak parliamentary election, held from September 30 - October 1, was the first democratic election since the Slovak Republic became an independent country in January 1993. Originally, the election was planned for June 1996, but due to 
the fact that the ruling party - the Movement for a Democratic Slovakia (HZDS) - lost its majority in the parliament, the political situation in the country changed and parliament agreed to call for a new election. Jozef Moravčík, former foreign minister and originally an ally of Vladimír Mečiar, formed a coalition government of five parties with the Party of the Democratic Left $\left(S D L^{\prime}\right)$ on the left, the Christian Democratic Movement $(K D H)$ on the right and the liberal Democratic Union $\left(D U^{\prime}\right)$ in the center, thus covering a large spectrum of interests. This government, certain about its prospects, backed the early election.

Elections were held in the four Slovak macro regions of the time - Bratislava, Western Slovakia, Central Slovakia, and Eastern Slovakia. Only parties that declared either 10,000 members, 100,000 votes from past elections, or 10,000 supporters (by petition) were able to participate in the 1994 electoral contest. A total of 18 political parties entered the election (Appendix 1). Results of the 1994 parliamentary contest, after a spirited election campaign, revealed that the populist Movement for a Democratic Slovakia $(H Z D S)$ won a plurality with $35 \%$ of valid votes (Figure 3 ). To create a new government $H Z D S$ formed a coalition together with the Agricultural Party of Slovakia (RSS), the nationalist Slovak National Party (SNS) (5.4\%), and the leftist Association of Workers of Slovakia $(Z R S)(7.3 \%)$. This was an enormous loss for the opposition, which clearly underestimated the popularity of $H Z D S$ 's leader, Vladimír Mečiar. 
Figure 3: 1994 Slovak parliamentary election - percentage of valid votes for political parties or political movements

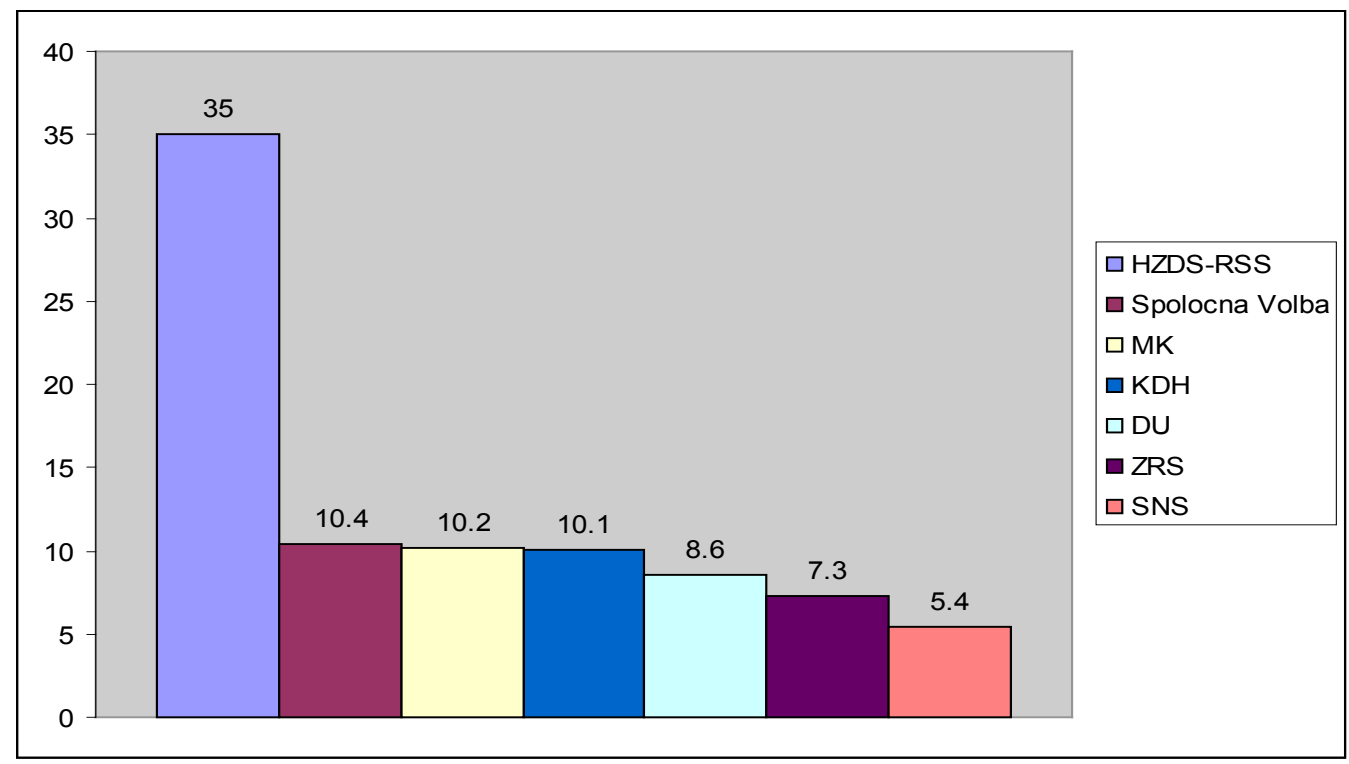

Movement for a Democratic Slovakia (HZDS)-Agricultural Party of Slovakia $(R S S)$ - $35 \%$

Common Choice (Spoločná Vol’ba) - $10.4 \%$

Hungarian Coalition Party $(M K)-10.2 \%$

Christian-Democratic Movement $(K D H)-10.1 \%$

Democratic Union of Slovakia $(D U ́)-8.6 \%$

Association of Workers of Slovakia (ZRS) - 7.3\%

Slovak National Party $(S N S)-5.4 \%$

Source: Statistical Office of the Slovak Republic (1994).

\section{Geographic Distribution of Votes in the 1994 Parliamentary Election}

Within the overall national party list vote, there were significant differences across the country in terms of party voting strength (Figure 4). Based on the regional patterns of electoral support in the 1994 election, $H Z D S-R S S$ with a total of $35 \%$ of valid 
votes had the highest share of votes in the Banskobystrický region in the districts of Detva (60.0\%) and Žarnovica (55.7\%); in Trenčiansky region in the districts of Kysucké Nové Mesto (59.7\%), Púchov and Ilava (55.3\%); and in Žilinský region in the districts of Bytča (59.0\%) and Čadca (56.9\%) (Appendix 1). The pro-reform Common Choice (Spoločná Vol'ba) acquired 10.4\% of votes in the 1994 election with the majority of its supporters living in the country's two largest cities - the city of Bratislava and Košice. In addition, Spoločná Vol'ba gained strong voter support in Trnavský region in the districts of Senica (17.0\%) and Skalica (15.6\%); in Prešovský region in the district of Medzilaborce (15.9\%); and in Košický region in the district of Rožňava (15.6\%)(Appendix 1).

The Hungarian Coalition $(M K)$ ranked third with a total of $10.2 \%$ of valid votes unsurprisingly securing the majority of its votes in southern Slovakia, where most ethnic Hungarians reside, specifically in Trnavský region in the districts of Dunajská Streda (83.2\%) and Galanta (9.9\%); in Nitriansky region in the districts of Komárno (71.0\%), Nové Zámky (39.9\%), and Šal’a (39.2\%); and in Banskobystrický region in the district of Rimavská Sobota (39.2\%) (Appendix 1); these districts have the highest percentage of ethnic Hungarians. The Christian Democratic Movement $(K D H)$, with $10.1 \%$ of the vote, found its main support in Žilinský region, especially in the districts of Námestovo (25.8\%) and Dolný Kubín (20.1\%) and in Prešovský region in the districts of Kežmarok (25.3\%), Levoča (24.4\%), and Prešov (20.8\%) (Appendix 1). The Democratic Union of Slovakia $\left(D U^{\prime}\right)$, which garnered $8.6 \%$ of valid votes, largely mirrored the pattern of the other main pro-reform party, Spoločná Vol'ba, with most of its supporters in the city of Bratislava and Košice. In addition, $D U$ found major support in Banskobystrický region in 
the districts of Banská Bystrica (14.6\%) and Zvolen (10.7\%); in Prešovský region in the districts of Poprad (13.4\%) and Prešov (10.6\%); and in Trnavský region in the district of Skalica (13.9\%) (Appendix 1).

The Association of Workers of Slovakia (ZRS), at $7.34 \%$ of valid votes, had widespread appeal geographically; that is, its voters were spread across the entire country, but especially in Banskobystrický region in the district of Revúca (19.7\%); in Prešovský region in the district of Medzilaborce (16.8\%); in Košický region in the district of Gelnica (13.7\%); and in Žilinský region especially in the districts of Martin (13.1\%) and Turčianske Teplice (12.6\%) (Appendix 1). The last political party that exceeded the required 5 percent threshold for parliamentary seats in the 1994 contest was the Slovak National Party $(S N S)$ with a total of $5.4 \%$ of valid votes. SNS had the predominant part of its electorate in Žilinský region in the districts of Tvrdošín (13.7\%) and Kysucké Nové Mesto (10.2\%); in Trenčiansky region in the district of Považská Bystrica (10.8\%); and in Bratislavský region in the districts of Bratislava V (10.0\%), Bratislava IV (9.6\%), and Pezinok (9.2\%) (Appendix 1).

In summary, in terms of the geographic distribution of votes in the 1994 Slovak parliamentary election, the pro-reform political parties (Common Choice, Democratic Union of Slovakia, the Hungarian Coalition, and the Christian Democratic Movement) were predominantly represented in Bratislavský, Prešovský, Košický, Trnavský, and Nitriansky regions, while opposition parties (Movement for a Democratic Slovakia, Agricultural Party of Slovakia, Association of Workers of Slovakia, and the Slovak National Party) had the most supporters in Banskobystrický, Žilinský, and Trenčiansky regions. 
Figure 4: Official results of the Slovak 1994 parliamentary election by region

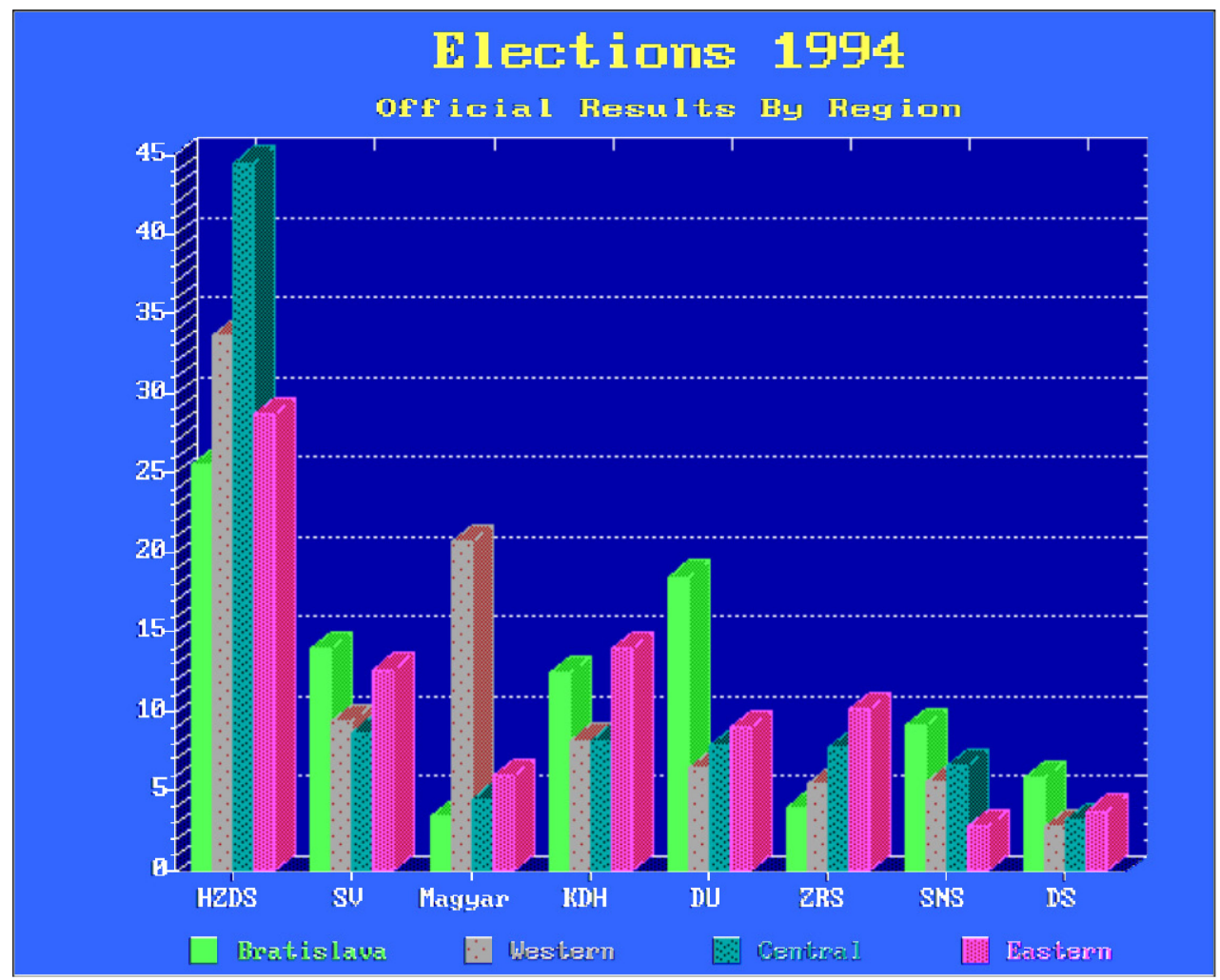

Source: Slovakia Document Store (1994).

http://slovakia.eunet.sk/slovakia/elections-94/resreg.gif.

\section{Slovak Parliamentary Election: Regional Patterns}

As was noted above, the 1998 parliamentary election was a major turning point for Slovak politics in the post-independence period, because it demonstrated that free and fair elections could clear the way for an opposition coalition to assume power via the ballot box and bring Slovakia to the path of democratic reform. The opposition was aware that they needed to create a critical mass to gain a larger share of votes than the Movement for a Democratic Slovakia $(H Z D S)$, therefore in 1997 the Slovak Democratic Coalition (SDK-Slovenská Demokratická Koalícia) was established as a party with right, 
left and center components. SDK had its origins in the Blue Coalition of the Democratic Party and the Christian Democratic Movement and there were five opposition political parties that became part of this coalition: the Democratic Union (DÚ - Demokratická Únia), the Democratic Party (DS - Demokratická Strana), the Social Democratic Party of Slovakia (SDSS - Sociálnodemokratická Strana Slovenska), the Christian Democratic Movement (KDH - Krestansko-Demokratické Hnutie) and the Slovak Green Party (SZS Strana Zelených na Slovensku) (Bútora and Bútorová 1999, 81). SDK became the focal political party in the 1998 electoral contest and its main purpose was to oppose the antidemocratic Mečiar.

Another party whose position was crucial in the 1998 election was the Party of the Democratic Left (SDL'-Strana Demokratickej L'avice), which decided not to join the $S D K$. It was mainly due to its prior unsuccessful participation in the coalition with SDSS and the Green Party (SZS - Strana Zelených na Slovensku) during the 1994 election. This coalition was created in order to keep $S D L^{\prime}$ separated from an alliance with Mečiar; therefore, before the 1998 electoral contest, $S D L$ remained an opposition faction.

The Party of Civic Understanding (SOP - Strana Občianskeho Porozumenia) was a new political party that emerged in March 1998. The party was created by Rudolf Schuster, Mayor of Slovakia's second largest city, Košice, a new and very charismatic politician. This party was viewed as "virtual" because of its publicity through commercial television and independent press. SOP received sufficient support from Slovak citizens and in September 1998 the party joined the coalition, establishing a center-left position within the opposition. 
All together there were 17 political parties participating in the 1998 election (Appendix 2). As a result of the electoral contest, while $H Z D S$ was able to win $27 \%$ of votes and 43 seats in the Slovak National Council, SDK was close behind with $26.3 \%$ and 42 seats. In addition, $S D K$ united with other opposition parties - SDL' with 23 seats, $S O P$ with 13 seats and the Hungarian Coalition Party (SMK - Strana Mad'arskej Koalicie) with 15 seats and received a constitutional majority of 93 out of 150 seats in the parliament (Figure 5).

Figure 5: 1998 Slovak parliamentary election - percentage of valid votes for political parties or political movements

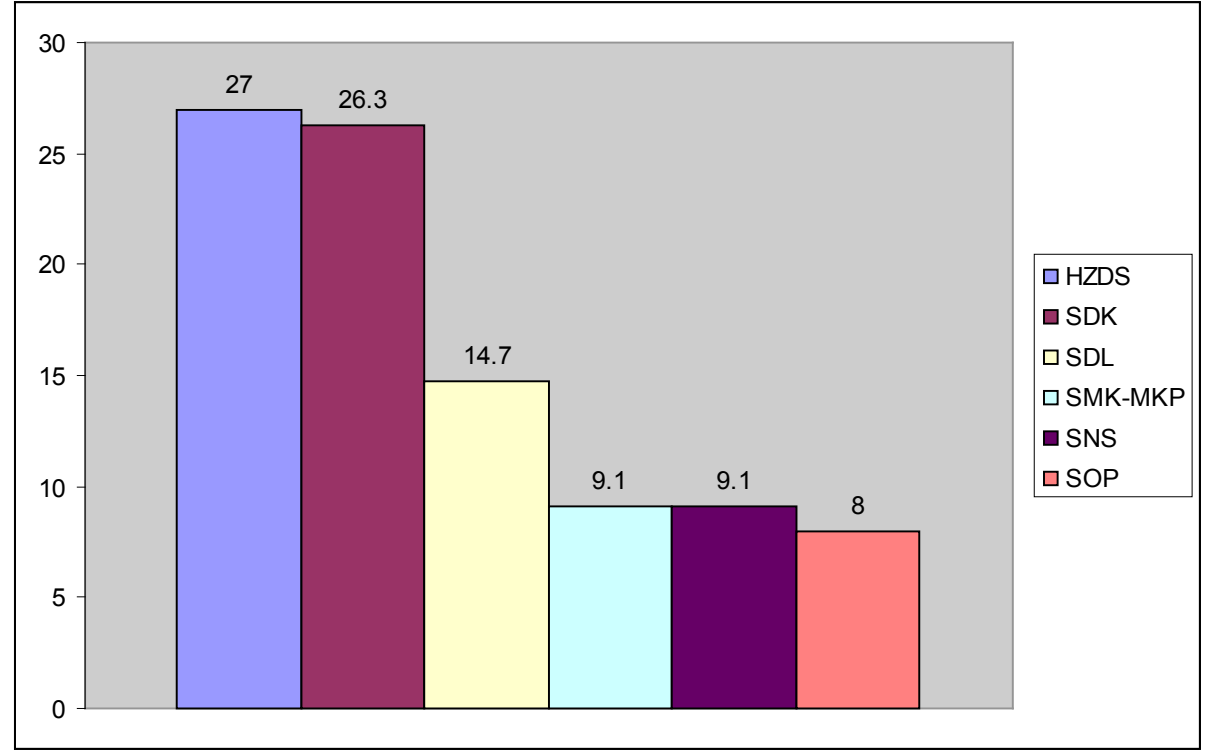

Movement for a Democratic Slovakia $(H Z D S)-27.0 \%$ (43)

Slovak Democratic Coalition $(S D K)$ - $26.3 \%$ (42)

Party of Democratic Left $\left(S D L^{\prime}\right)-14.7 \%(23)$

Hungarian Coalition Party $(S M K-M K P)-9.1 \%(15)$

Slovak National Party (SNS) - $9.1 \%$ (14)

Party of Civic Understanding (SOP) - $8.0 \%$ (13)

Source: Statistical Office of the Slovak Republic (1998). 
After winning the election, Mikuláš Dzurinda, a leader of the right-leaning $S D K$, the largest political party in the government, was appointed as the new prime minister of Slovakia, replacing the anti-democratic Vladimír Mečiar, the dominant figure of Slovak politics since the fall of communist regime in 1989. The Slovak Republic was a communist country for more than forty years. The Velvet Revolution seemed to send off the old regime, but it also brought something similar to the previous regime Mečiarism ${ }^{6}$. Thus, the 1998 parliamentary election was a challenge for the opposition to finally achieve democracy and choose a new government that would be able to move Slovakia along the democratic path. Slovak society, frustrated with the previous government, created intense civic mobilization, with a dramatic increase in voter participation from $75.7 \%$ in 1994 to $84.2 \%$ in 1998, which made a difference in the 1998 electoral contest ${ }^{7}$. In addition, although there were differences among political parties in the opposition coalition, due to its broad spectrum of representation, all parties agreed on three main goals - the necessity of renewing democracy in the country, restoring the rule of law, and bringing Slovakia closer to European Union and NATO.

\section{Geographic Distribution of votes in the 1998 Slovak Parliamentary Election}

Once again, dramatic differences were manifested from place to place in party voting affinities. As Figure 6 below illustrates, the Movement for a Democratic Slovakia, uniting both right and left wing elements, received the majority of its votes from voters in

\footnotetext{
${ }^{6}$ Mečiarism refers to controversial leadership of Vladimír Mečiar. Mečiar tried to use all levels of power to control every segment of the country.

${ }^{7}$ Statistical Office of the Slovak Republic. 1994 and 1998 parliamentary elections. http://portal.statistics.sk/showdoc.do?docid=4490.
} 
the northwestern parts of the country. The highest share of valid votes were shown in Žilinský region in the districts of Čadca (54.6\%), Kysucké Nové Mesto (49.9\%), and Bytča (49.5\%); in Trenčiansky region in the districts of Považská Bystrica (46.9\%) and Púchov (45.8\%); and in Banskobystrický region in the district of Žarnovica (46.9\%). These were the same districts where $H Z D S$ received the highest rate of valid votes in the 1994 election (Appendix 2).

Figure 6: Percentage of valid votes for a political party by districts - HZDS

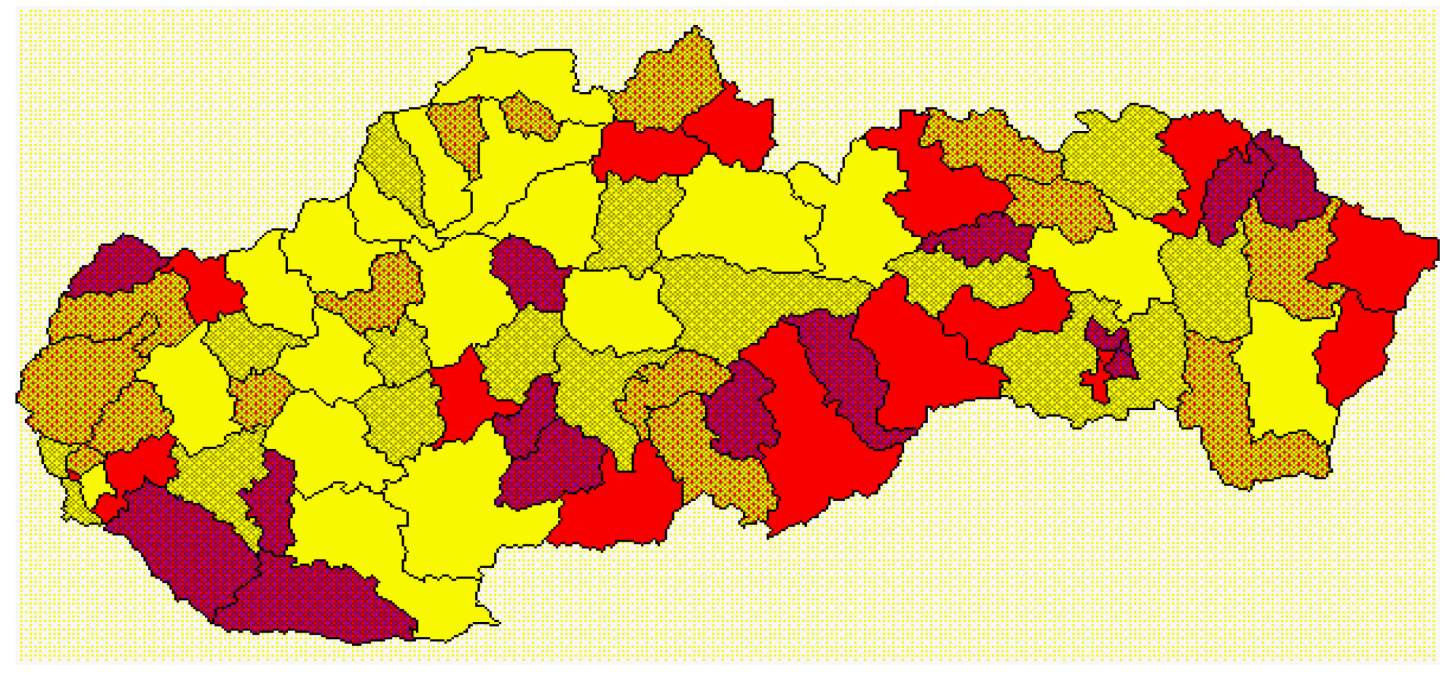

$2,83-18,50$

$18,51-24,40$

$24,41-31,71$

$31,72-37,30$

$37,31-54,61$

Source: Statistical Office of the Slovak Republic (1998).

In the case of the Slovak Democratic Coalition that was formed from four opposition parties and received a constitutional majority of 93 votes in the Slovak Parliament (26.3\%), the largest number of valid votes for this political party was received 
in all five Bratislava districts and in western Slovakia in general (Figure 7). In addition to votes from people living in Bratislavský region, $S D K$ had also many supporters in Trnavský region in the district of Skalica (49.3\%) and in Prešovský region in the districts of Prešov (40.6\%) and Kežmarok (40.5\%). In comparison to the 1994 electoral contest, $S D K$ was able to take over the most electorate of Spoločná Vol'ba and $K D H$ and secure its mass support in districts where Spoločná Vol'ba and $\mathrm{KDH}$ used to be dominant (Appendix 2).

Figure 7: Percentage of valid votes for a political party by districts - SDK

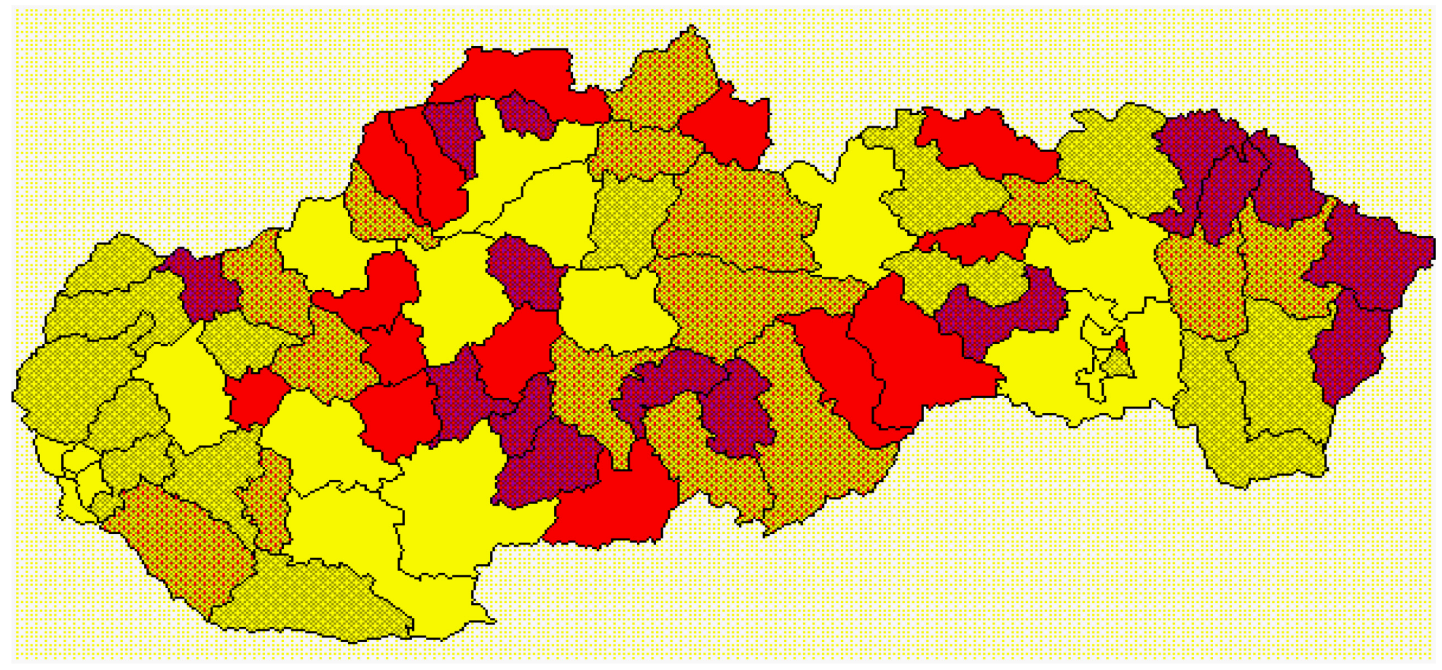

$11,61-17,26$

$17,27-19,94$

$19,95-24,43$

$24,44-30,38$ $30,39-53,89$

Source: Statistical Office of the Slovak Republic (1998). 
As Figure 8 below suggests, the Party of the Democratic Left, with a total of $14.7 \%$ of valid votes in the 1998 election, found most of its supporters in central Slovakia. The highest rate of votes was received in Banskobystrický region in the districts of Banská Bystrica (26.1\%), Zvolen (23.3\%), Krupina (22.8\%), Revúca (22.0\%), and Brezno (21.8\%); as well as in Žilinský region in the district of Liptovský Mikuláš (22.2\%) (Appendix 2).

Figure 8: Percentage of valid votes for a political party by districts - SDL

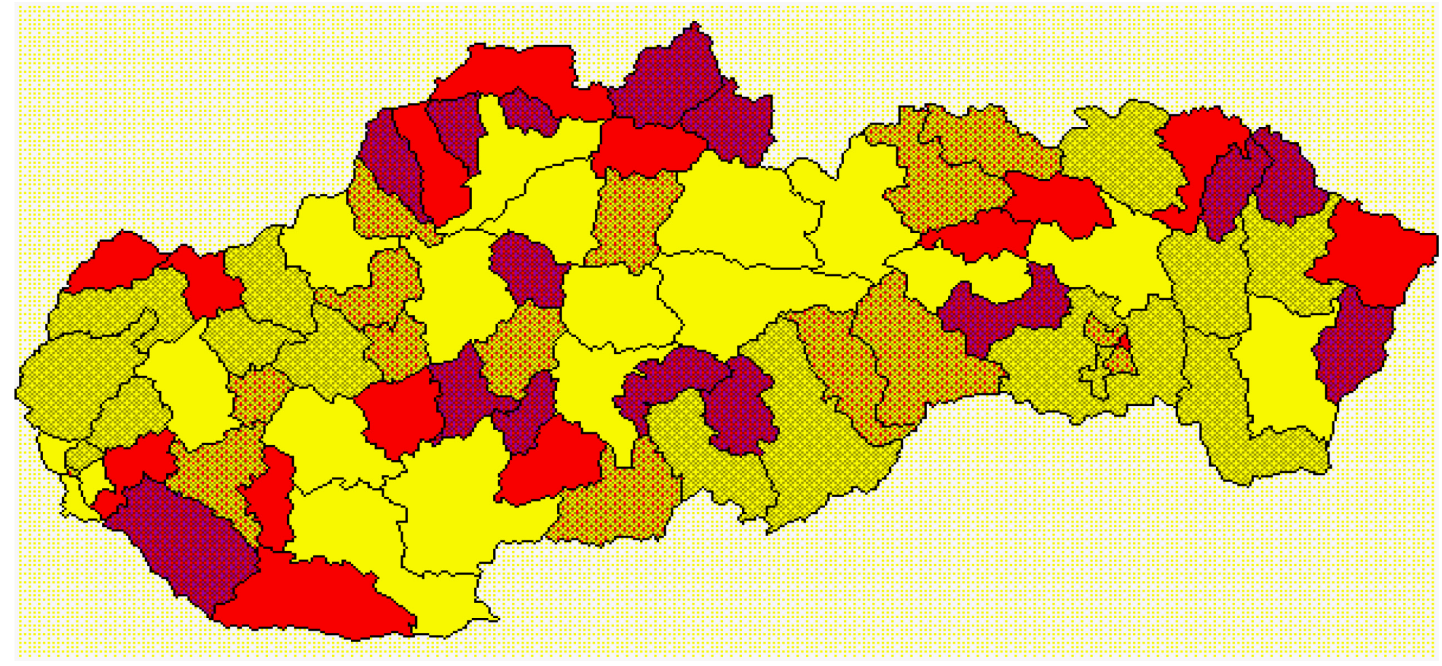

$2,58-11,56$

$11,57-13,80$

$13,81-15,52$

$15,53-17,07$

$17,08-26,13$

Source: Statistical Office of the Slovak Republic (1998).

As was noted earlier, it is no surprise that the Hungarian Coalition Party had the most followers in the southern parts of the Slovak Republic where most of the Hungarian minority lives (Figure 9). Specifically, in Trnavský region the districts of Dunajská 
Streda (79.3\%) and Galanta (35.9\%); in Nitriansky region the districts of Komárno (66.4\%), Nové Zámky (36.0\%), and Šal’a (34.4\%); and in Banskobystrický region the district of Rimavská Sobota (35.0\%), demonstrated a majority of votes for the Hungarian Coalition Party in the 1998 parliamentary election. These were the same districts where $S M K-M K P$ won in 1994 election (Appendix 2).

Figure 9: Percentage of valid votes for a political party by districts - SMK-SKP

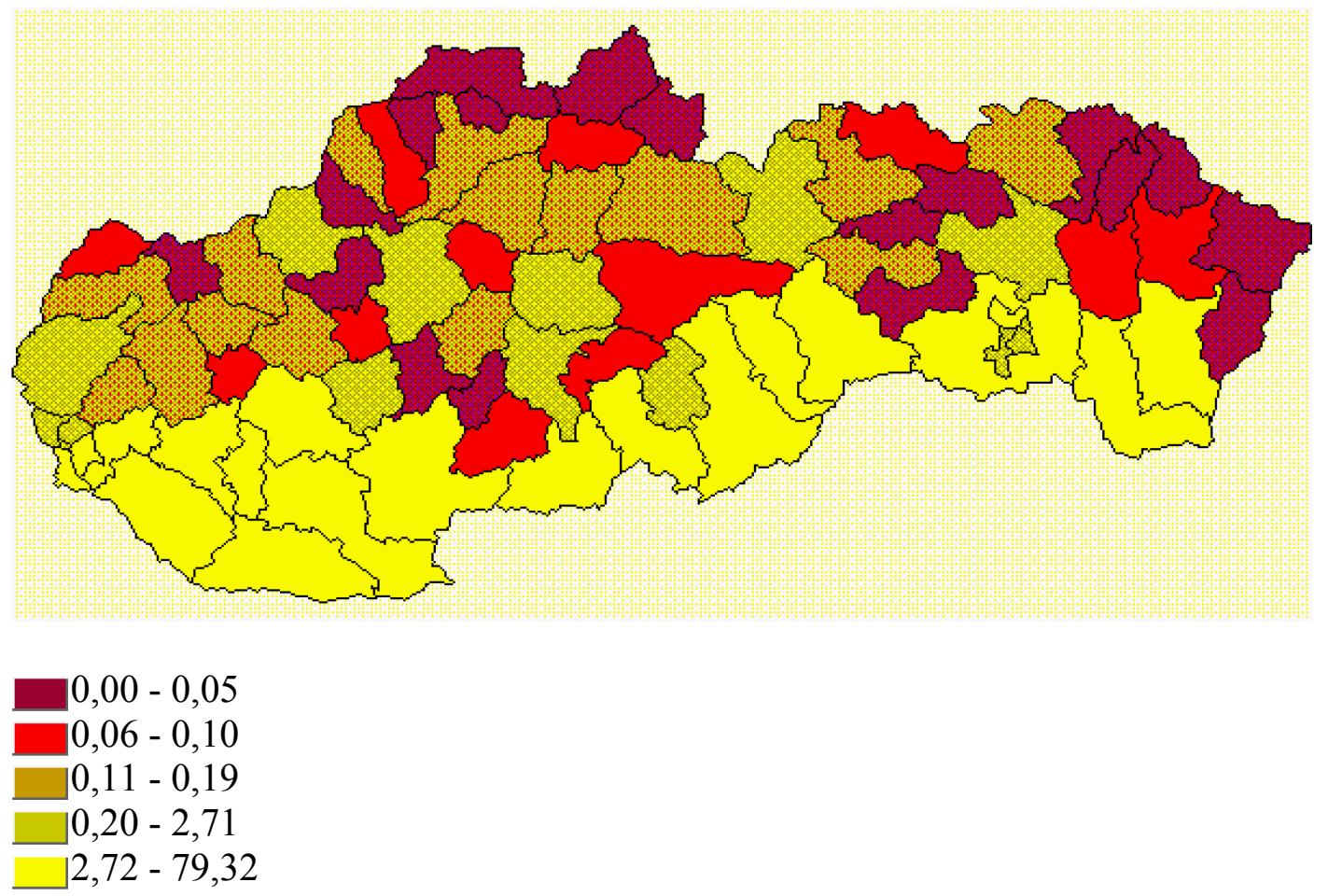

Source: Statistical Office of the Slovak Republic (1998).

In the 1998 parliamentary electoral contest, the Slovak National Party, with a total of $9.1 \%$ of valid votes was mainly represented by voters from the central and northern part of Slovakia (Figure 10). Especially high rates of votes were received in Žilinský 
region in the districts of Žilina (23.7\%), Kysucké Nové Mesto (21.6\%), Tvrdošín (19.2\%), and Bytča (19.0\%); in Trenčiansky region in the district of Považská Bystrica (17.0\%); and in Banskobystrický region in the district of Detva (16.7\%). According to regional patterns of voting, $S N S$ continued to receive the mass of voters' support in the same districts as during the 1994 electoral contest. In addition, $S N S$ was able to gain part of the electorate that supported HZDS in the 1994 election (Appendix 2).

Figure 10: Percentage of valid votes for a political party by districts - SNS

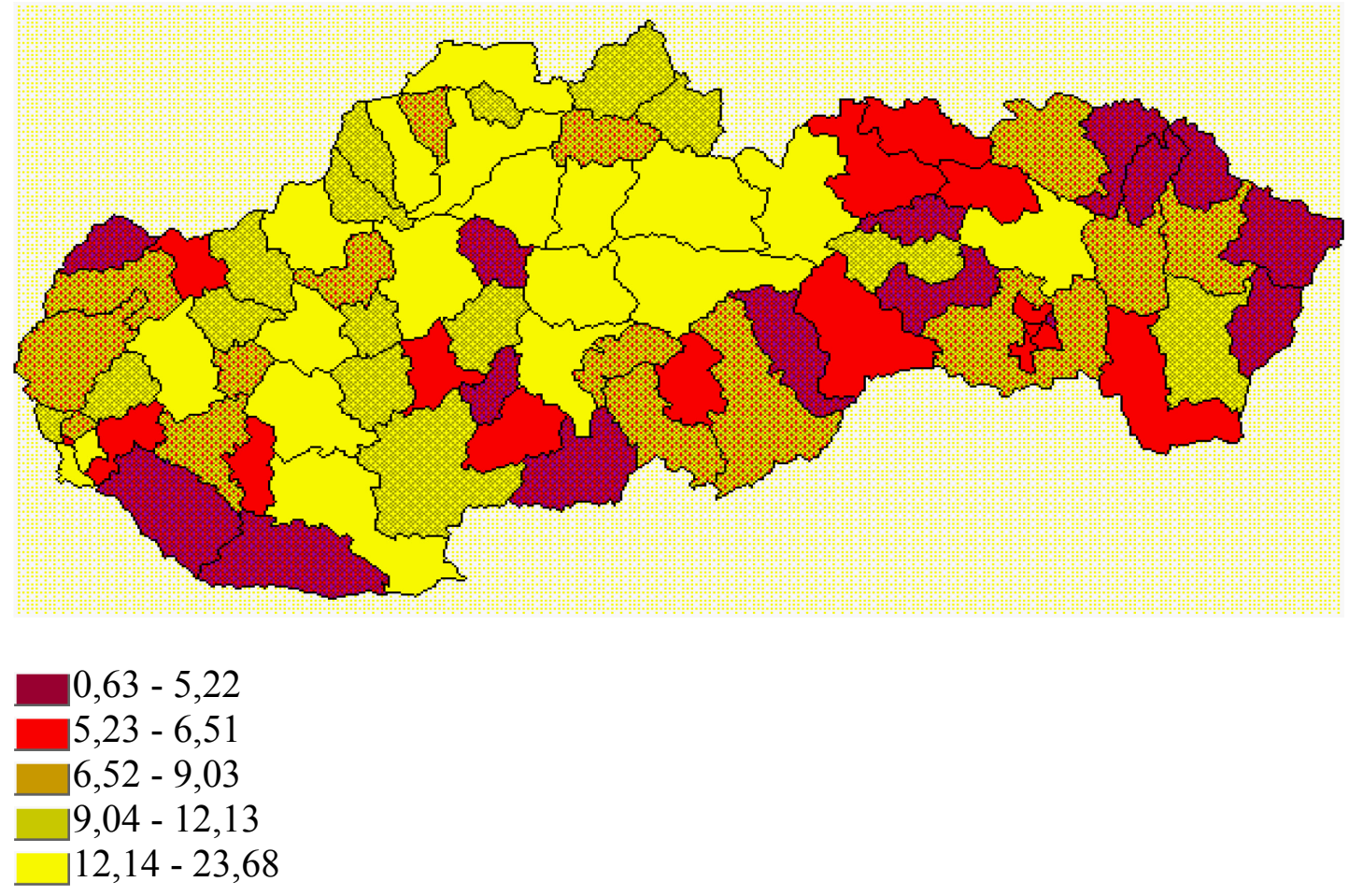

Source: Statistical Office of the Slovak Republic (1998).

The last party that was able to obtain representation in the parliament with a total of $8.0 \%$ of valid votes was the Party of Civic Understanding. Thanks to the party's founder Rudolf Schuster, the popular mayor of the city of Košice, a city located in the 
eastern part of Slovakia, the majority of party's followers were from districts located in eastern Slovakia (Figure 11), particularly in Košický region in all districts of city of Košice, Trebišov (16.1\%), Rožňava (14.2\%), and Michalovce (13.2\%) and in Prešovský region in the districts of Humenné (13.7\%), Snina (13.1\%), and Medzilaborce (12.5\%). The analysis of the electoral support confirms that $S O P$ most probably received a portion of its votes from voters who supported Spoločná Vol'ba in the 1994 electoral contest (Appendix 2).

Figure 11: Percentage of valid votes for a political party by districts - SOP

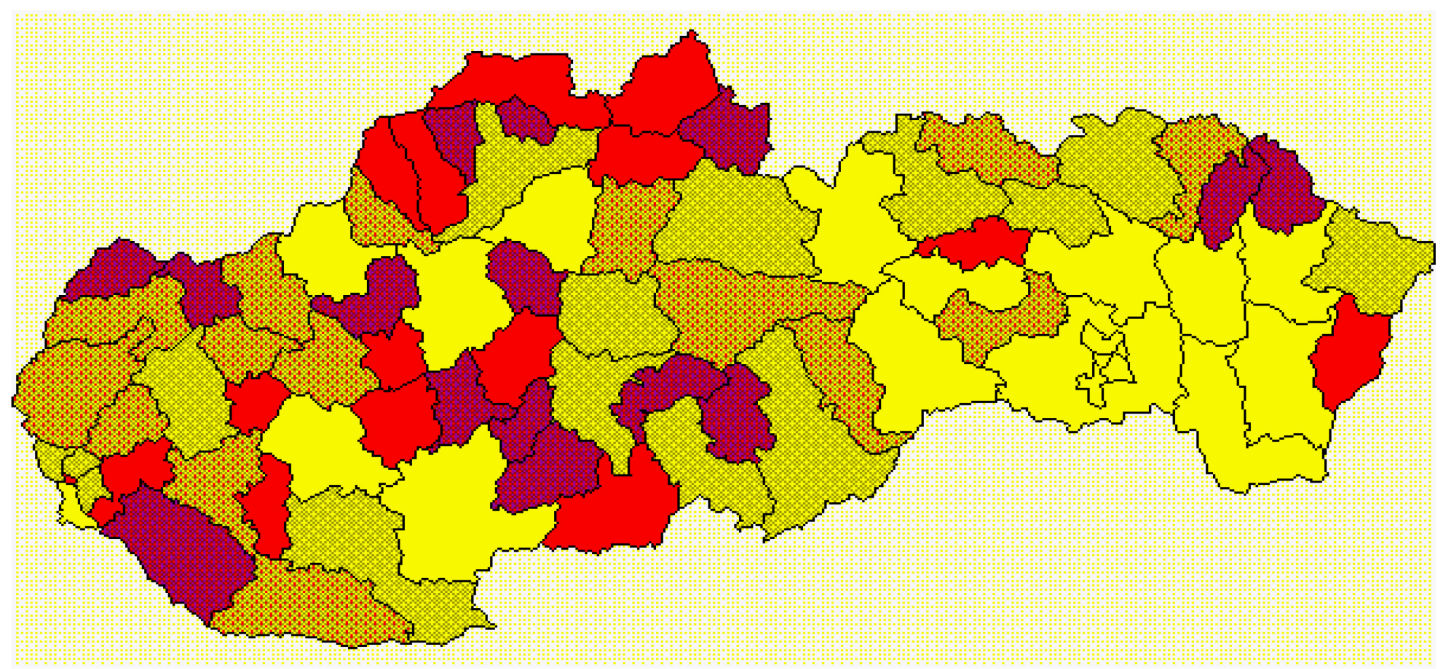

$1,43-4,63$

$4,64-5,75$

$5,76-6,91$

$6,92-9,86$

$9,87-28,44$

Source: Statistical Office of the Slovak Republic (1998). 
In summary, in terms of the geographic distribution of votes in 1998 Slovak parliamentary election the pro-reform political parties (Slovak Democratic Coalition, Hungarian Coalition Party, and Party of Civic Understanding) received the majority of their votes in Bratislavský, Trnavský, Nitriansky, Prešovský, and Košický regions, while populist and post-communist parties (Movement for a Democratic Slovakia, Party of the Democratic Left, and the Slovak National Party) were predominantly represented in Banskobystrický, Žilinský, and Trenčiansky regions. This is exactly the same pattern of geographical distribution of votes from 1994 election.

\section{Slovak Parliamentary Election: Regional Patterns}

On September 20-21 2002, the Slovak Republic held its third parliamentary election since it became a sovereign country in 1993 . With a total of $4,157,802$ registered voters casting ballots, overall voter participation was $70.1 \%$. Although this was a slight decrease in voter participation in comparison to the 1994 and 1998 Slovak parliamentary elections with $75.7 \%$ and $84.2 \%$ respectively, the turnout illustrated that Slovak people were serious about the electoral process and the political stakes involved ${ }^{8}$.

This election was indeed crucial for the future of the Slovak Republic. As the 1994 election represented a farewell to communism, and the 1998 election the end of Mečiar's leadership, the possibility of Slovakia joining NATO and the European Union became a major factor in the 2002 parliamentary electoral contest. There was an overall consensus that the results of the 2002 Slovak parliamentary election would decide

\footnotetext{
${ }^{8}$ Statistical Office of the Slovak Republic. 1994, 1998, and 2002 parliamentary elections - total voting results. http://portal.statistics.sk/showdoc.do?docid=4490.
} 
whether Slovakia would continue and actually conclude its integration process into NATO and the European Union (Mesežnikov 1999, 14-15).

In the 2002 Slovak parliamentary election, a total of 26 political parties were registered to compete, a significant increase in the number of political parties from 18 in 1994 and 17 in $1998^{9}$. From the complete number of political parties, 13 of were new political subjects formed during 1998-2002. The two most important among the new political parties were the Alliance of New Citizens (ANO - Aliancia Nového Občana), founded in April 2001, and SMER established in 1999. ANO aimed to promote free enterprises by reducing the influence of the Slovak state on the economy, while $S M E R$, with its leader Robert Fico, was established to create space for the arrival of a new political generation in Slovakia.

Among new political parties, there were three parties created by leaders who left their previous affiliations due to internal conflicts. First, the True Slovak National Party (PSNS - Pravá Slovenská Národná Strana) was founded in October 2001 by former leader Ján Slota and other former members of the Slovak National Party (SNS Slovenská Národná Strana). The program of the PSNS was almost identical with the program of the $S N S$, mainly aimed against giving support to the Hungarian minority. In addition, the PSNS opposed Slovak membership in NATO. Another newly-formed political party was the Party for Democracy (HZD - Hnutie za Demokraciu) created by the former members of the Movement for a Democratic Slovakia (HZDS - Hnutie za Demokratické Slovensko), and the Slovak Democratic Alliance established by the former

\footnotetext{
${ }^{9}$ Statistical Office of the Slovak Republic. 1994, 1998, and 2002 parliamentary elections - registered political parties. http://portal.statistics.sk/showdoc.do?docid=4490.
} 
politicians from the Party of the Democratic Left ( $S D L^{\prime}$ - Strana Demokratickej Lavice). In all three cases because members of $S N S, H Z D S$ and $S D L^{\prime}$ were unable to solve their internal conflicts, this eliminated any possibility for future cooperation between the old and newly established parties.

Eight of 26 parties contesting the 2002 election were on the Slovak political scene since the first democratic parliamentary election held in 1994 in exactly same form or with a slight modification. They were: the Slovak Democratic and Christian Union (SDKÚ), the Movement for a Democratic Slovakia (HZDS), the Party of Hungarian Coalition $(S M K)$, the Christian Democratic Movement $(K D H)$, the Slovak National Party $(S N S)$, the Party of the Democratic Left $(S D L)$, the Association of Workers of Slovakia $(Z R S)$ and the Communist Party of Slovakia (KSS). In addition, from all parties that participated in the 2002 parliamentary election, two - the Green Party in Slovakia (SZS) and the Roma Civic Initiative (ROMA) - also competed in the 1994 election, while the Slovak National Unity $(S N J)$ and the B-Revolutionary Worker's Party (B-RPS) participated in the 1998 parliamentary race.

With a total of $19.5 \%$ of valid votes, the official winner of the 2002 parliamentary election became Mečiar's Movement for a Democratic Slovakia (HZDS) (Figure 12). In second place was the Slovak Democratic and Christian Union (SDKÚ) with $15.1 \%$ of valid votes, followed by SMER with $13.5 \%$ of valid votes, then the Party of Hungarian Coalition $(S M K)$ with $11.2 \%$ of valid votes, the Christian Democratic Movement $(K D H)$ with $8.3 \%$ of valid votes, the Alliance of New Citizen $(A N O)$ with $8.0 \%$ of valid votes, 
and the Communist Party of Slovakia $(K S S)$ with $6.3 \%$ of valid votes ${ }^{10}$. The results of the 2002 parliamentary contest also illustrated that 13 political parties did not receive even 1 percent of votes, two ( $S D A$ and $S D L)$ secured less than 2 percent of votes, and three (PSNS, SNS and HZD) obtained less than $4 \%$ of valid votes. This demonstrated weak party organization, poor strategy, hubris, or a lack of situational awareness among party leaders from these 13 political parties who were aware of their low voters' preferences from the beginning of the election campaign and their small or no chance to pass the required $5 \%$ threshold, which is one of the downside implications of the proportional representation electoral system as discussed above.

Figure 12: 2002 parliamentary election - percentage of valid votes for political parties or political movements

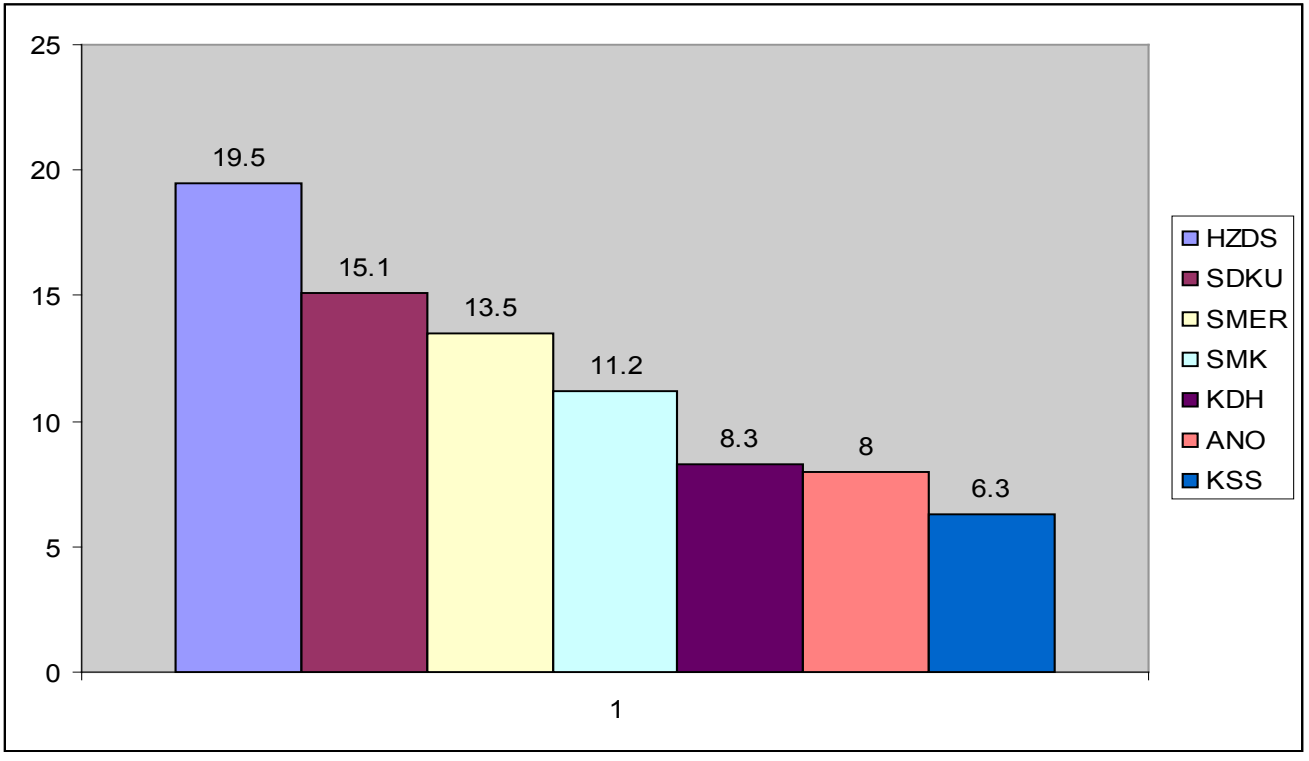

\footnotetext{
${ }^{10}$ Statistical Office of the Slovak Republic. 2002 parliamentary election - percentage of valid votes for political parties or political movements. http://portal.statistics.sk/volby2002/webdata/engl/tab/tab3.htm.
} 
Movement for a Democratic Slovakia $(H Z D S)$ - $19.5 \%$

Slovak Democratic and Christian Union $(S D K U ́)-15.1 \%$

SMER - $13.5 \%$

Party of Hungarian Coalition $(S M K)-11.2 \%$

Christian Democratic Movement $(K D H)-8.3 \%$

Alliance of New Citizen $(A N O)$ - $8.0 \%$

Communist Party of Slovakia (KSS) - 6.3\%

Source: Statistical Office of the Slovak Republic (2002).

From the total of 26 registered political parties, only seven were able to exceed the required 5 percent threshold in order to secure seats in the parliament. As the Figure 13 below illustrates, the Movement for a Democratic Slovakia (HZDS) was assigned 36 seats, the Slovak Democratic and Christian Union (SDKÚ) 28 seats, SMER 25 seats, the Party of Hungarian Coalition $(S M K) 20$ seats, the Christian Democratic Movement $(K D H) 15$ seats, the Alliance of New Citizen $(A N O) 15$ seats, and the Communist Party of Slovakia $(K S S) 11$ seats in the parliament ${ }^{11}$.

\footnotetext{
${ }^{11}$ Statistical Office of the Slovak Republic. 2002 parliamentary election - numbers of seats assigned to political parties. http://portal.statistics.sk/volby2002/webdata/engl/graf/graf2.htm.
} 
Figure 13: Numbers of seats assigned to political parties

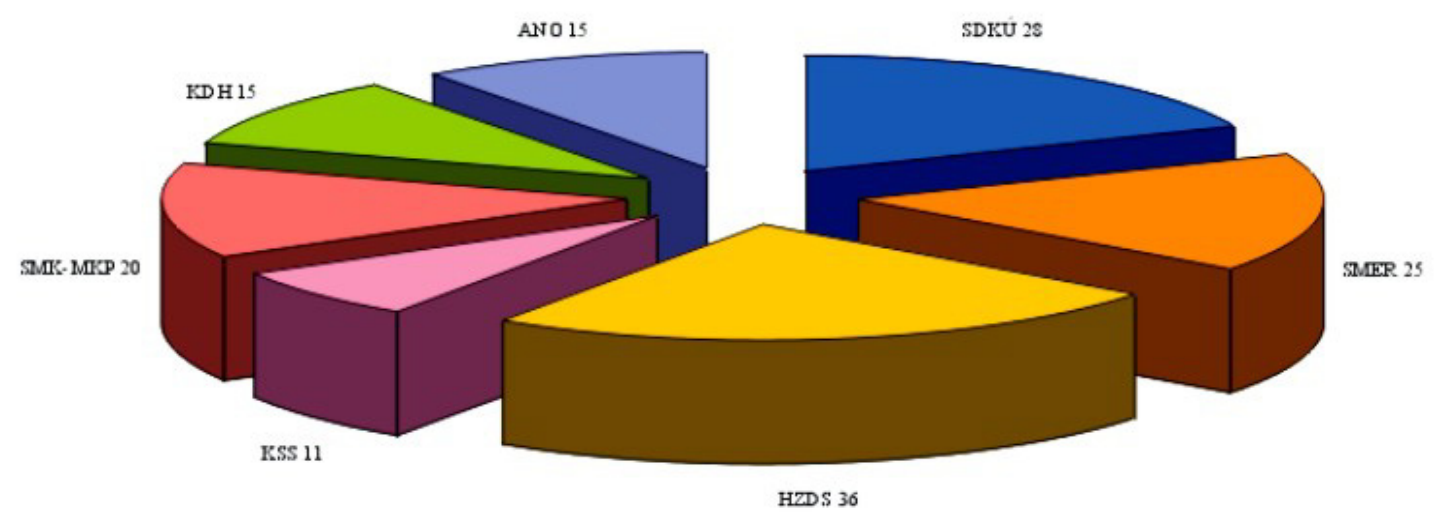

Source: Statistical Office of the Slovak Republic (2002b).

http://portal.statistics.sk/volby2002/webdata/engl/graf/graf2.htm.

Based on election results, there was only one real possibility for the government coalition. First, no political party was willing to enter a coalition with the winner of the 2002 Slovak parliamentary election, Mečiar's HZDS, or the Communist Party of Slovakia. Also, in order to have a coalition with similar political programs and based on previous experiences of the former government, the center-right political parties were not interested in having the left-oriented SMER in its coalition either. Therefore, the parliamentary majority of the center-right oriented political parties with the total of 78 seats allowed $S D K U$, $S M K, K H D$ and $A N O$ to create a coalition formed only from the right-oriented political parties. Mikuláš Dzurinda once again became the new prime minister and the three political parties - winning HZDS, SMER and KSS announced their departure into the opposition. 


\section{Geographic Distribution of votes in 2002 Parliamentary Election}

As was true in 1994 and 1998, there were pronounced geographical differences across Slovakia in the voting for the national party list (Figures 14 and 15).

Figure 14: 2002 parliamentary election - winning political parties in Slovakia by districts

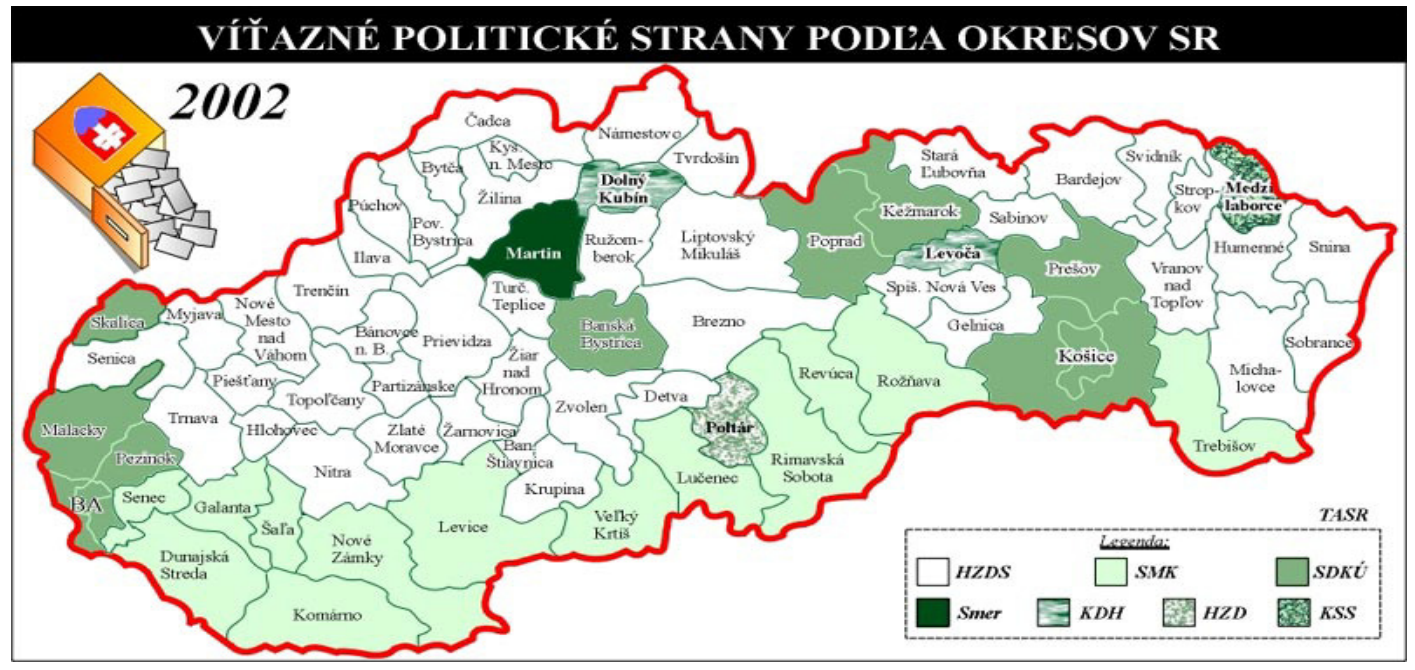

Source: Sme.sk (2002). http://volby.sme.sk/c/674423/vitazne-politicke-strany-podlaokresov-slovenskej-republiky.html. 
Figure 15: 2002 parliamentary election - political parties with the highest number of valid votes in districts

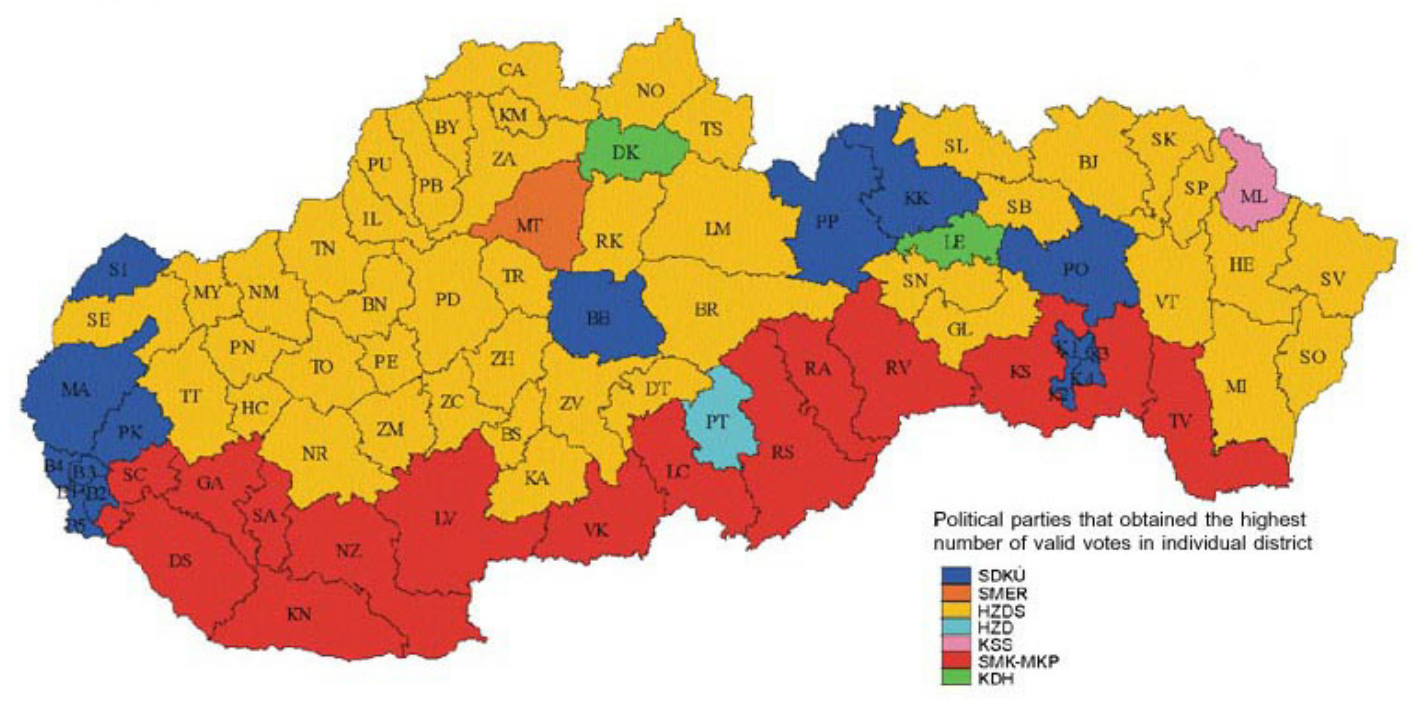

Source: Statistical Office of the Slovak Republic (2002c).

http://www.statistics.sk/volby2002/webdata/slov/graf/strokr.htm.

Based on the 2002 election results, the Slovak Democratic and Christian Union received the highest share of votes in Bratislavský region in the districts of Bratislava I (40.7\%), Bratislava IV (36.4\%), Bratislava V (35.7\%), Bratislava II (33.6\%), and Bratislava III (33.2\%) (Figure 16). In addition, SDKU's other major supporters were from the eastern Slovakian district of Košice that represented $29.4 \%$ of votes. In comparison to the 1998 parliamentary election, $S D K U$ was able to secure a majority of its votes in the districts that voted for the $S D K$ in previous elections, especially in the district of Bratislava. In addition, the $S D K U$ most probably received most of its votes from the Democratic Party $(D S)$ that withdrew from the contest just few days prior, and 
also from the Slovak Democratic Alliance $(S D A)$ because these parties shared similar values. In addition, $S D K U$ most likely secured part of the electorate that voted for the Party of Civic Understanding (SOP) in 1998. In terms of the regional distribution of votes, $S D K U$ had the most followers in districts where Spoločná Vol'ba and $D U$ were the strongest in the 1994 election and where $S D K$ gained the majority of its support in the 1998 electoral contest (Appendix 3).

Figure 16: Percentage of valid votes for a political party by districts - SDKÚ

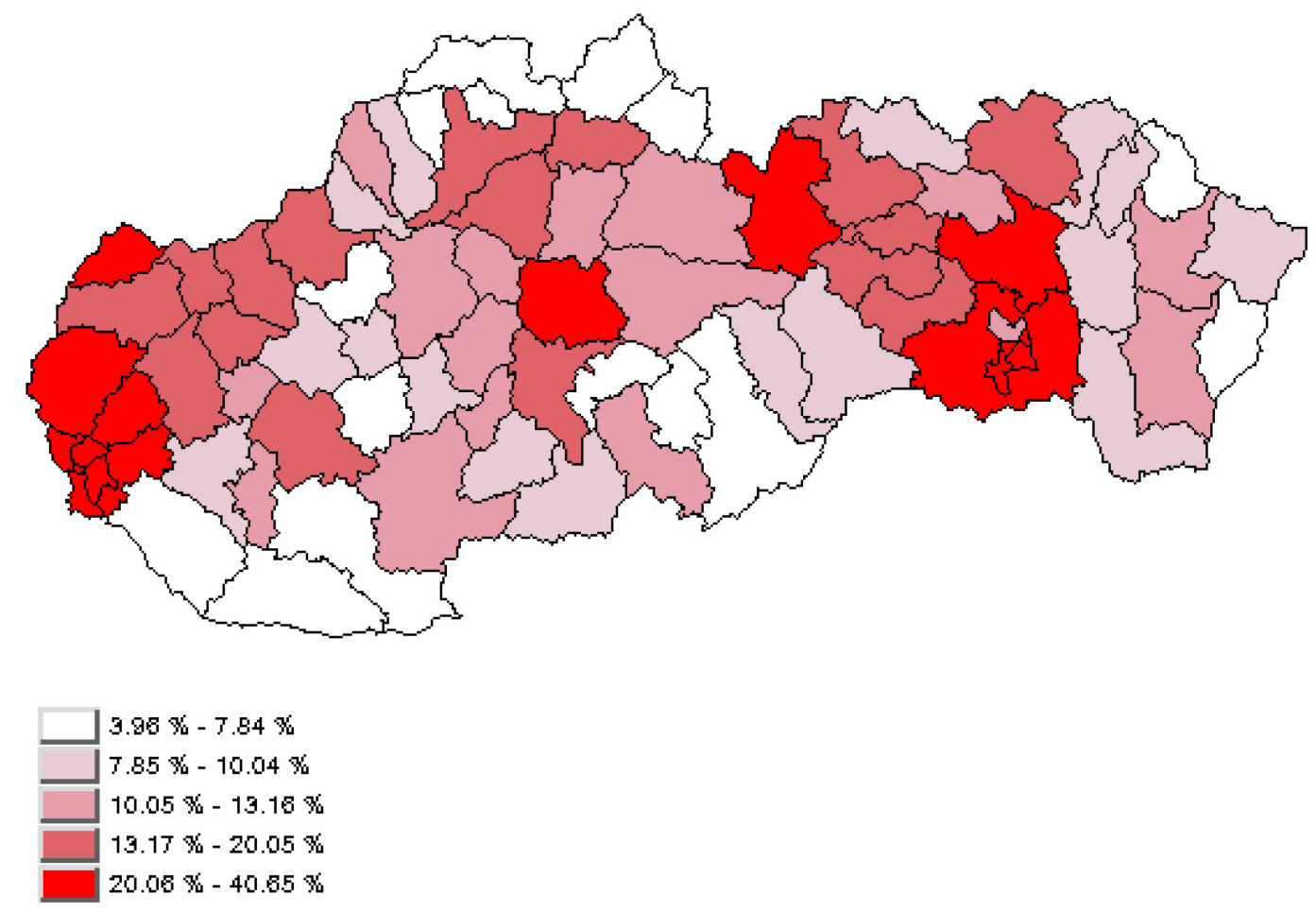

Source: Statistical Office of the Slovak Republic (2002).

SMER, a new political party in the 2002 parliamentary election, received most of its votes in Prešovský region in the district of Medzilaborce (20.4\%); in Trnavský region 
in the districts of Hlohovec (18.9\%), Trnava (18.3\%), Senica (17.7\%), and Skalica (17.6\%); and in Žilinský region in the district of Martin (18.4\%) (Figure 17). SMER was able to take over most of the electorate from regions where HZDS-RSS and ZRS had the highest rate of votes in the 1998 election and where $H Z D S, S D L$, and $S D K$ were dominating in the 1994 contest (Appendix 3).

Figure 17: Percentage of valid votes for a political party by districts - SMER

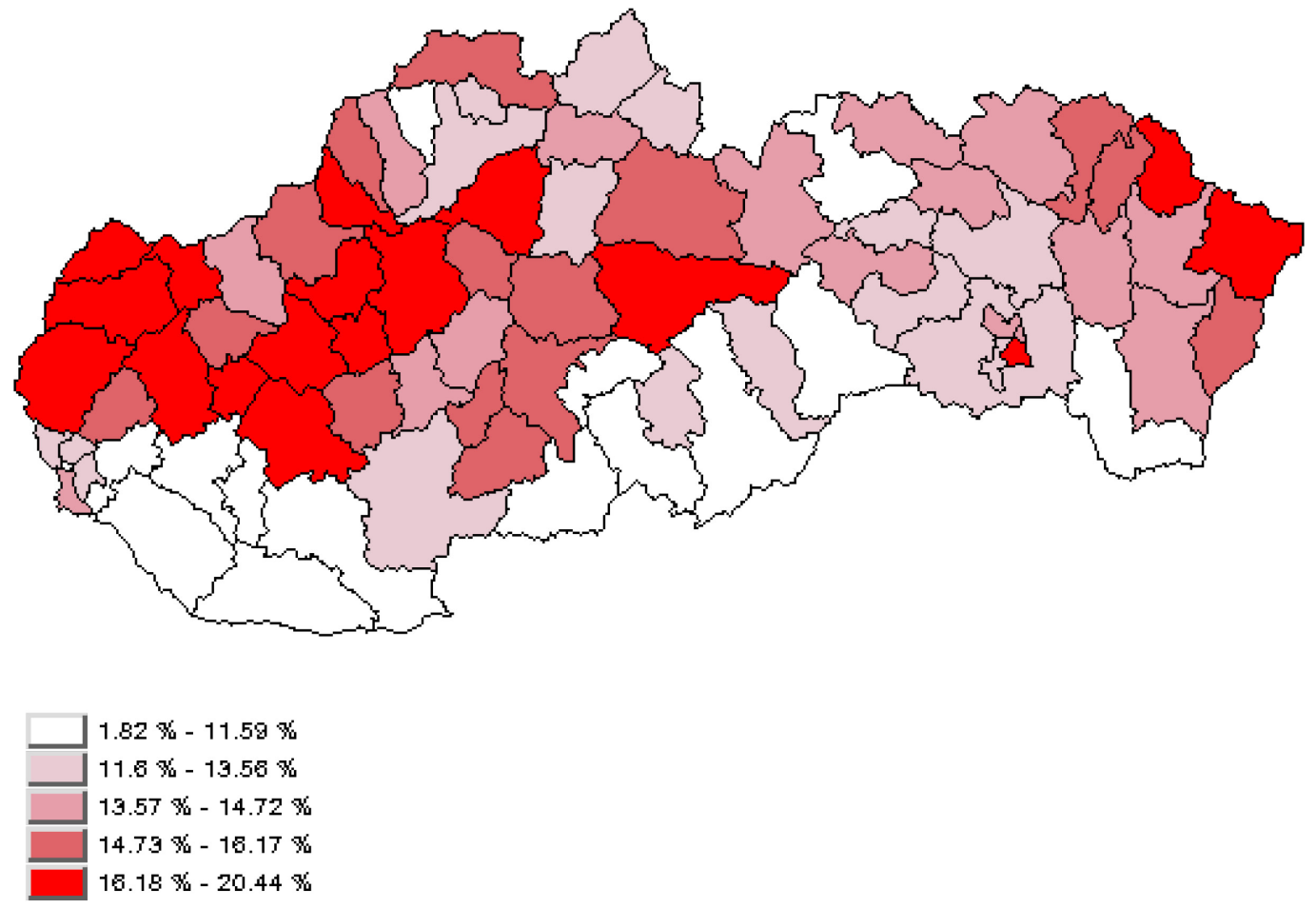

Source: Statistical Office of the Slovak Republic (2002).

$A N O$, also a new political party with its leader Pavol Rusko (who owned the first private Slovak TV station, Markíza), gained the majority of its support in Košický region especially in the city of Košice; as well as in Žilinský region in the district of Liptovský 
Mikuláš (15.2\%); in Prešovský region in the districts of Poprad (13.6\%) and Kežmarok (12.3\%); and in Banskobystrický region in the districts of Zvolen (12.5\%) and Banská Bystrica (12.3\%) (Figure 18). The analysis of the regional electoral support illustrates that $A N O$ 's electorate came from districts that voted for HZDS-RSS, Spoločná Vol'ba, and $D U^{\prime}$ in the 1994 election and for $S D K, H Z D S$, and $S D L^{\prime}$ in the 1998 election (Appendix 3).

Figure 18: Percentage of valid votes for a political party by districts - ANO

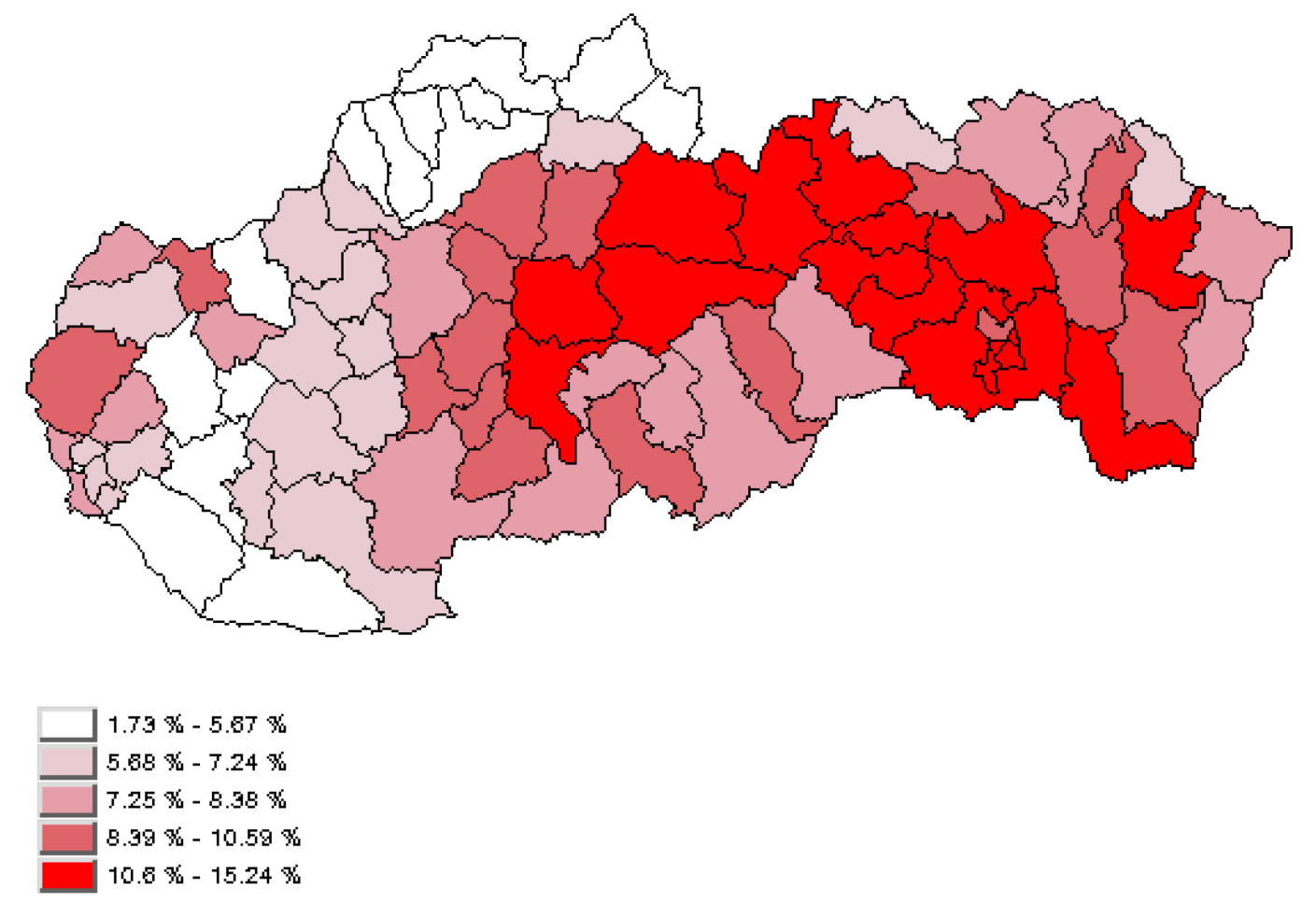

Source: Statistical Office of the Slovak Republic (2002).

As was the case in 1994 and 1998, the fact that the Hungarian minority lives along the Hungarian border in the southern parts of the country means that the Party of Hungarian Coalition's voters distribution in the 2002 parliamentary election are to be 
found in these same areas (Figure 19). As in 1998, SMK-MKP received most of their votes in Trnavský region in the districts of Dunajská Streda (86.2\%) and Galanta (42.9\%); in Nitriansky region in the districts of Komárno (74.6\%), Nové Zámky (43.1\%), and Šala (41.1\%); and in Banskobystrický region in the district of Rimavská Sobota (37.0\%). In each of these districts support for SMK slightly increased in comparison to 1998 parliamentary election. In addition, these were the same districts where $S M K-M K P$ had the highest rate of votes in the 1994 electoral contest as well (Appendix 3).

Figure 19: Percentage of valid votes for a political party by districts - SMK-MKP

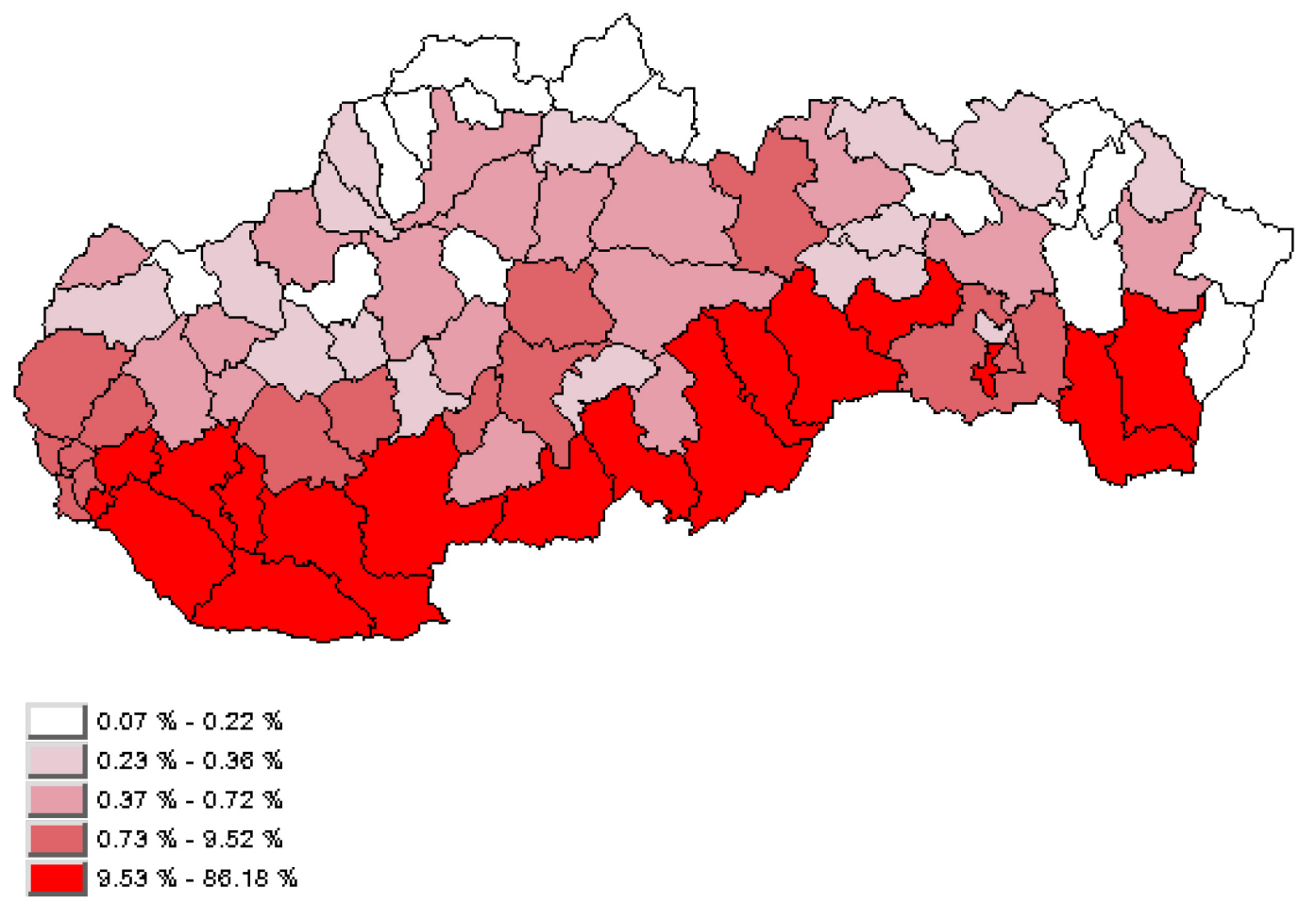

Source: Statistical Office of the Slovak Republic (2002). 
The Movement for a Democratic Slovakia $(H Z D S)$ gained the majority of its votes in the 2002 parliamentary election in Žilinský region in the districts of Čadca (41.3\%), Bytča (38.8\%), and Kysucké Nové Mesto (38.7\%); in Trenčiansky region in the districts of Púchov (38.1\%) and Považská Bystrica (37.6\%); and in Banskobystrický region in the district of and Detva (34.8\%) (Figure 20). Not surprisingly, these were the same districts where HZDS had the most supporters in the 1994 and 1998 elections; however there was a major decrease in numbers for HZDS in these districts in the 2002 contest (Appendix 3).

Figure 20: Percentage of valid votes for a political party by districts - HZDS

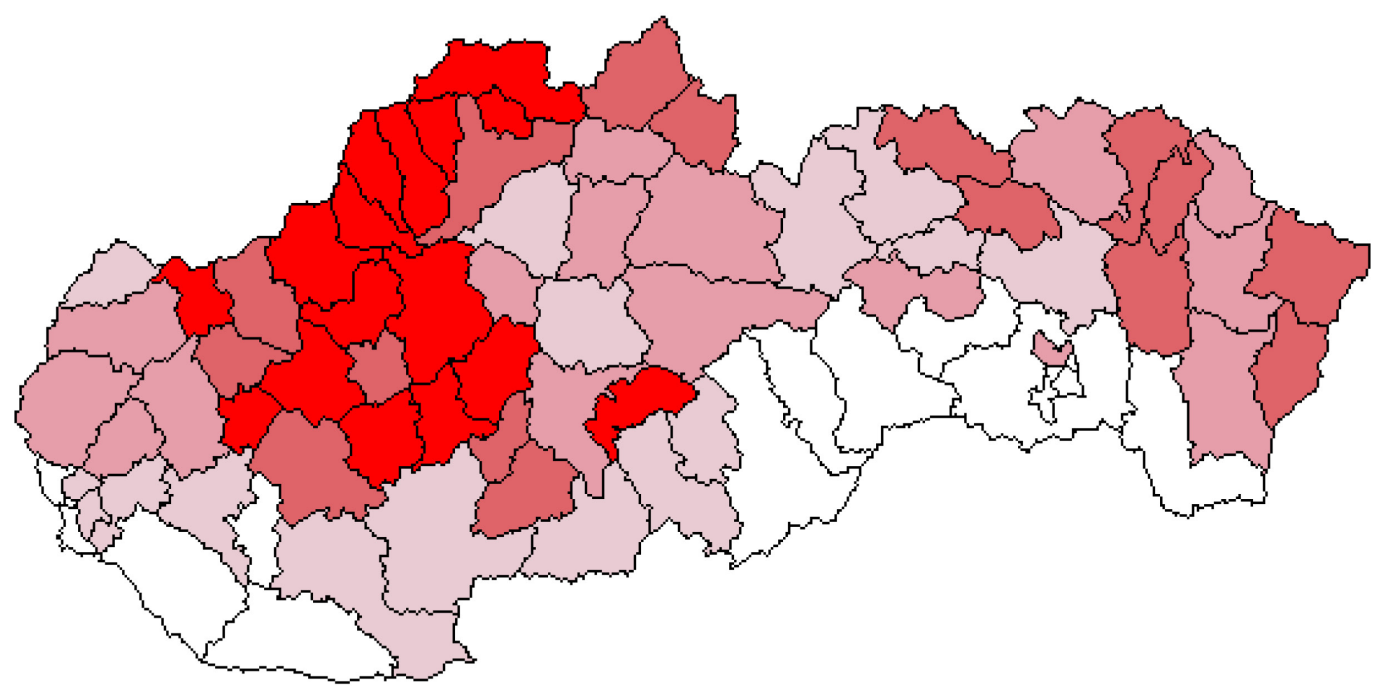
$1.78 \%-12.42 \%$
$12.49 \%-17.49 \%$
$17.44 \%-2.9 .08 \%$
$23.09 \%-29.20 \%$
$29.21 \%-41.28 \%$

Source: Statistical Office of the Slovak Republic (2002). 
With a total of $8.3 \%$ of valid votes, the Christian Democratic Movement gained the majority of its support in Prešovský region in the districts of Kežmarok $(25.3 \%)$, Levoča (24.4\%), and Prešov (20.8\%) and in Žilinský region in the districts of Námestovo (25.8\%), Dolný Kubín (20.1\%), and Tvrdošín (19.6\%) (Figure 21). These are exactly the same regions were $K D H$ had support from in the 1994 election. Moreover, the analysis of the regional electoral support illustrates that $K D H$ 's electorate also comes from districts that previously voted for the Slovak National Party in the 1994 contest and for the Slovak Democratic Coalition in the 1998 election (Appendix 3).

Figure 21: Percentage of valid votes for a political party by districts $-\mathrm{KDH}$

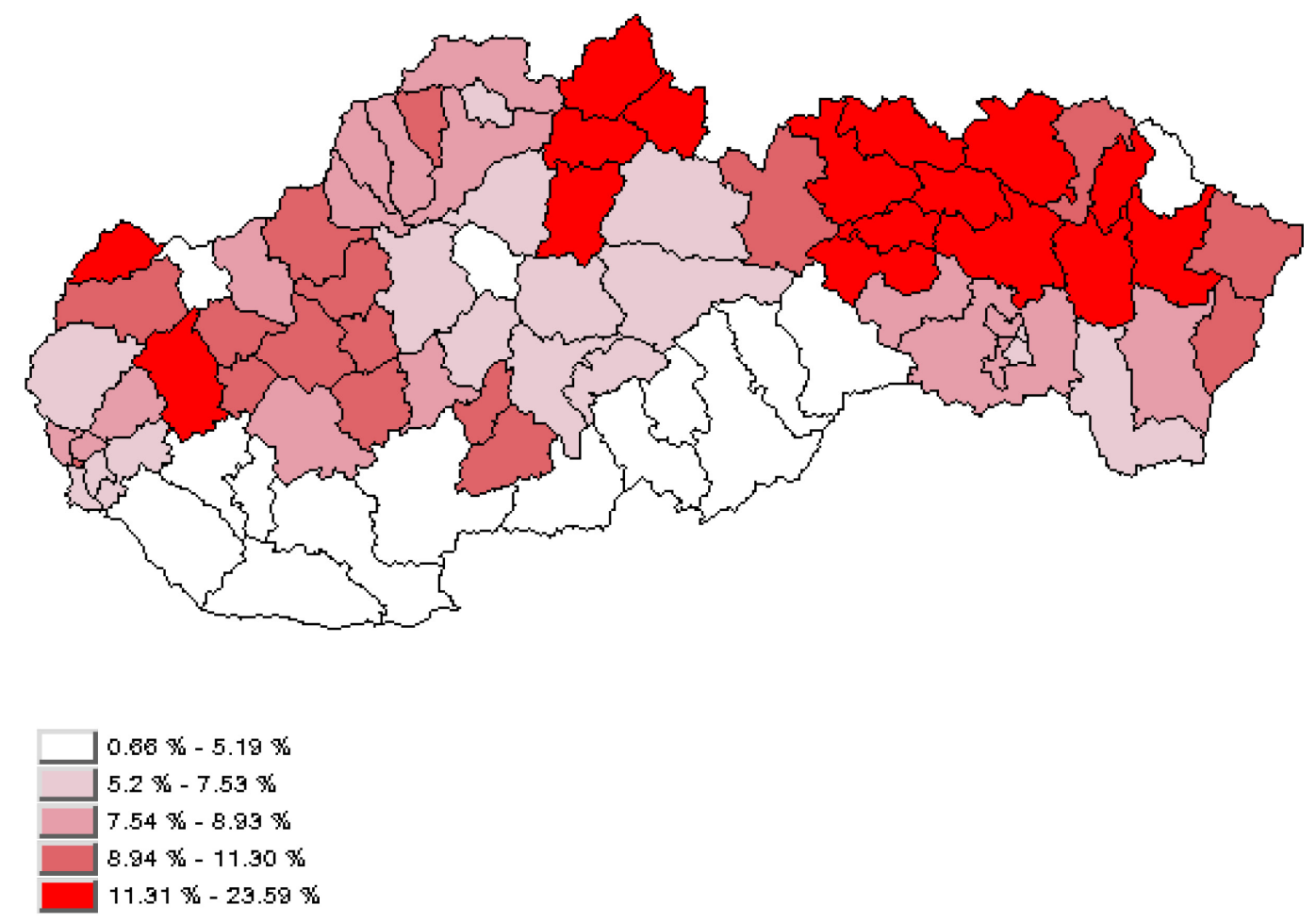

Source: Statistical Office of the Slovak Republic (2002). 
Receiving a total of $6.32 \%$ of valid votes, the 2002 parliamentary election was a great success for the Communist Party of Slovakia (KSS). KSS was able to increase their electoral support from $0.72 \%$ in 1994 and $2.79 \%$ in the 1998 parliamentary election. KSS received the mass of its votes in eastern and central Slovakia, specifically in Prešovský region in the districts of Medzilaborce (24.9\%) and Svidník (15.5\%); in Banskobystrický region in the districts of Poltár (15.4\%) and Revúca (13.8\%); in Žilinský region in the district of Turčianske Teplice (15.2\%); and in Košický region in the district of Gelnica (14.9\%), (Figure 22). KSS received the highest rate of votes in districts which voted for HZDA-RSS and ZRS in the 1994 election and for HZDS and SDL' in the 1998 electoral contest.

Figure 22: Percentage of valid votes for a political party by districts - KSS

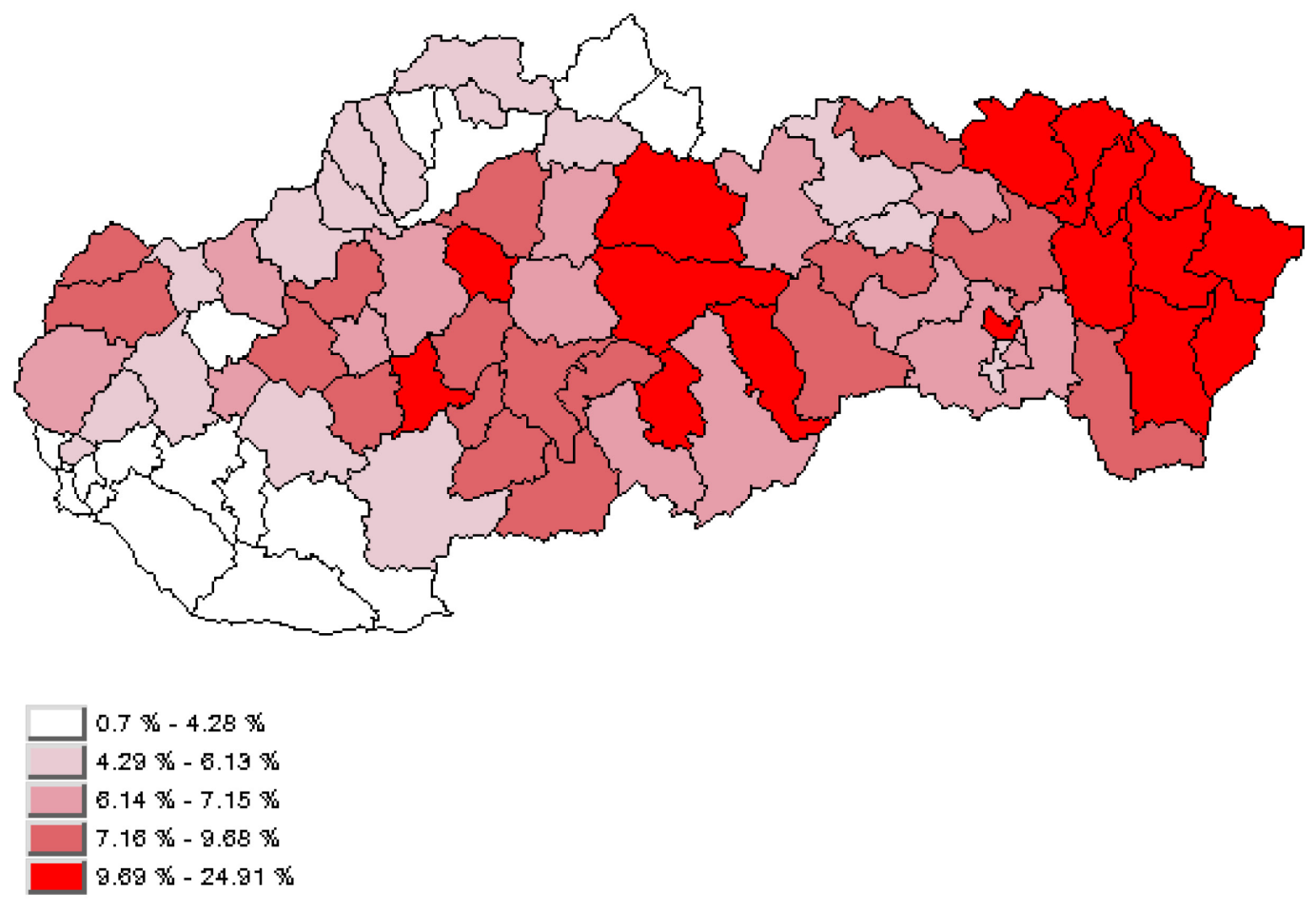

Source: Statistical Office of the Slovak Republic (2002). 
In summary, in terms of the geographic distribution of votes in the 2002 Slovak parliamentary election the pro-reform political parties (Alliance of New Citizens, Slovak Democratic and Christian Union, Hungarian Coalition, and the Christian Democratic Movement) were predominantly represented in Bratislavský, Prešovský, Košický, and Nitriansky regions, while opposition parties (Movement for a Democratic Slovakia, SMER, and the Communist Party of Slovakia) had the most supporters in Banskobystrický, Žilinský, and Trenčiansky regions. This was a continuing trend in the geographical support of political parties previously seen in the 1994 and 1998 parliamentary elections. The only change was in Trnavský region where SMER took over some of the SDK's electorate and as a result this region illustrated balanced support between pro-reform and opposition political parties.

Furthermore, as has been evident in the electoral geography literature cited previously, most countries evince a definite spatial pattern of political affinities, as expressed in voting for parties or for candidates representing parties. From the foregoing it is evident that Slovakia is no exception, with clear party preferences shown in specific areas. Further, this analysis of regional variations in voting behavior in the 1994, 1998, and 2002 Slovak parliamentary elections confirms that there is a strong tendency among voters in certain regions to provide continuous support to the same political parties over time. What remains is to investigate the underlying social, economic, and cultural traits of the regions to ascertain those characteristics of these areas that can be linked empirically and conceptually to voting outcomes. This is the task that I undertake in the section that follows. 


\section{Statistical Correlations and Survey Data}

With the above spatial patterns of political preference in mind, the task now shifts to relating these electoral outcomes to the underlying socio-economic structure of the 79 districts. Again, we employ here aggregate data and, in the first instance, the voting results are compared with the socio-economic variables through a matrix of bivariate correlations (Tables 3-5). These statistical results are analyzed in light of the general literature on the socio-economic determinants of voting behavior in post-communist Central Europe. Secondly, the aggregate data results are compared with findings from public opinion polling in Slovakia itself in 1998 and 2002 to validate (or not) the correlations.

Based on the literature, we expect to find the following statistical correlations between socio-economic characteristics of voters and voters' electoral choices in Slovakia per se:

1. Less educated voters are inclined to vote for post-communist/populist parties.

2. Voters with higher education are more likely supportive of pro-reform parties.

3. Younger voters tend to vote for pro-reform parties.

4. Older voters are more inclined to vote for post-communist/populist parties and/or parties that are on the left of the political spectrum.

5. Voters of Hungarian nationality tend to vote for parties explicitly representing the interests of the Hungarian minority.

6. Voters living in districts with high unemployment rates are likely to vote for post-communist/populist parties. 
7. Pro-reform parties tend to be more supported in urban areas.

8. Women voters tend to vote for pro-reform political parties.

9. Pro-reform parties are the ones who explicitly supported European Union membership. 
Table 3: Socio-economic and 1994 electoral data - Pearson correlations

\begin{tabular}{|c|c|c|c|c|c|c|c|}
\hline & $\begin{array}{c}\text { HZDS- } \\
\text { RSS }\end{array}$ & MK & $\begin{array}{c}\text { SPOLOCNA } \\
\text { VOLBA }\end{array}$ & SNS & KDH & DU & ZRS \\
\hline Urban Population & 0.19 & -0.152 & $.350^{\circ}$ & 0.107 & $.239^{2}$ & $498^{\circ}$ & 0.151 \\
\hline $\begin{array}{l}\text { Gender - Men } \\
\text { Permanently residing } \\
\text { population }\end{array}$ & -0.108 & -0.139 & $-.335^{\prime \prime}$ & -0.17 & $-.280^{\circ}$ & $-.514^{\pi}$ & -0.091 \\
\hline $\begin{array}{l}\text { Gender - Women } \\
\text { Permanently residing } \\
\text { population }\end{array}$ & 0.11 & 0.138 & $335^{\circ}$ & 0.172 & $280^{\circ}$ & $513^{\pi}$ & 0.092 \\
\hline $\begin{array}{l}\text { Gender - Men } \\
\text { Economically active } \\
\text { population }\end{array}$ & -0.107 & 0.027 & $-.316^{\circ}$ & -0.17 & -0.155 & $-.473^{\pi}$ & -0.093 \\
\hline $\begin{array}{l}\text { Gender - Women } \\
\text { Economically active } \\
\text { population }\end{array}$ & 0.107 & -0.027 & $.316^{\circ}$ & 0.17 & 0.155 & $.473^{\circ}$ & 0.093 \\
\hline Hungarian Nationality & -0.155 & $993^{\circ}$ & -0.091 & -0.166 & $-.247^{x}$ & -0.107 & -0.108 \\
\hline Unemployment & $-559^{\circ}$ & $258^{\circ}$ & -.622 & 0.039 & $.452^{\circ}$ & $-.690^{\circ}$ & $-.427^{\circ}$ \\
\hline $\begin{array}{l}\text { Work Force } \\
\text { Distribution } \\
\text { Industry }\end{array}$ & 0.19 & -0.195 & -0.012 & -0.171 & 0.028 & -0.166 & 0.167 \\
\hline $\begin{array}{l}\text { Work Force } \\
\text { Distribution } \\
\text { Business }\end{array}$ & $214^{*}$ & 0.136 & $.279^{\pi}$ & 0.008 & 0.059 & $331^{\pi}$ & 0.161 \\
\hline $\begin{array}{l}\text { Work Force } \\
\text { Distribution } \\
\text { Finance } \\
\end{array}$ & 0.064 & -0.009 & $254^{\star}$ & 0.152 & $.302^{\pi}$ & $452^{\circ}$ & 0.019 \\
\hline $\begin{array}{l}\text { Work Force } \\
\text { Distribution } \\
\text { Real Estate }\end{array}$ & $216^{x}$ & -0.034 & $461^{10}$ & 0.125 & $320^{\circ}$ & $634^{\pi}$ & 0.185 \\
\hline Age Group 25-34 Men & -0.178 & -0.1 & $-.400^{\circ}$ & -0.143 & $-.245^{*}$ & $-.513^{\pi}$ & -0.171 \\
\hline $\begin{array}{l}\text { Age Group } 2534 \\
\text { Women }\end{array}$ & 0.178 & $0: 1$ & $400^{\circ}$ & 0.143 & $.245^{x}$ & $513^{\prime \prime}$ & 0.171 \\
\hline Age Group $35-44$ Men & -0.12 & -0.039 & $-.291^{\prime \prime}$ & -0.126 & -0.143 & $-.401{ }^{\pi}$ & -0.113 \\
\hline $\begin{array}{l}\text { Age Group 35-44 } \\
\text { Women }\end{array}$ & 0.12 & 0.039 & $291^{\pi}$ & 0.126 & 0.143 & $.401^{\pi}$ & 0.113 \\
\hline Age Group 45.54 Men & -0.029 & -0.094 & -0.202 & -0.097 & -0.146 & $-.343^{\prime \prime}$ & -0.044 \\
\hline $\begin{array}{l}\text { Age Group } 45-54 \\
\text { Women }\end{array}$ & 0.029 & 0.094 & 0.202 & 0.097 & 0.146 & $343^{\prime \prime}$ & 0.044 \\
\hline $\begin{array}{l}\text { Age Group } 45-54 \\
\text { Total }\end{array}$ & $268^{x}$ & 0.087 & $.413^{n}$ & 0.046 & $266^{*}$ & $487^{\prime \prime}$ & $247^{*}$ \\
\hline Age Group 55.59 Men & 0.193 & 0.104 & $246^{*}$ & -0.133 & 0.082 & 0.197 & $231^{*}$ \\
\hline $\begin{array}{l}\text { Age Group } 55-59 \\
\text { Women } \\
\end{array}$ & -0.193 & -0.104 & $-.246^{x}$ & 0.133 & -0.082 & -0.197 & $-.231^{*}$ \\
\hline Age Group 18.59 Men & $220^{x}$ & 0.148 & $325^{\circ}$ & 0.03 & 0.078 & $358^{\prime \prime}$ & 0.205 \\
\hline $\begin{array}{l}\text { Age Group } 18-59 \\
\text { Women }\end{array}$ & $248^{*}$ & 0.181 & $.339^{\circ}$ & 0.008 & 0.095 & $358^{\prime \prime}$ & $231^{*}$ \\
\hline $\begin{array}{l}\text { Elementary Education } \\
\text { Women }\end{array}$ & $-.262^{x}$ & $.446^{\circ}$ & $-.343^{\prime \prime}$ & -0.105 & $-.242^{x}$ & $-.489^{\prime \prime}$ & -0.165 \\
\hline $\begin{array}{l}\text { Elementary Education } \\
\text { Total }\end{array}$ & $-.321^{\prime \prime}$ & $423^{\prime \prime}$ & $-.380^{\prime \prime}$ & -0.08 & $-.268^{x}$ & $-.511^{\pi}$ & $-.212^{*}$ \\
\hline $\begin{array}{l}\text { Complete Secondary } \\
\text { Vocational Education } \\
\text { Men }\end{array}$ & 0.15 & $-473^{\prime \prime}$ & -0.114 & -0.018 & -0.01 & -0.182 & 0.056 \\
\hline $\begin{array}{l}\text { Complete Secondary } \\
\text { Vocational Education } \\
\text { Women }\end{array}$ & $210^{*}$ & $-.444^{\prime \prime}$ & -0.047 & -0.006 & 0.019 & -0.132 & 0.105 \\
\hline $\begin{array}{l}\text { Complete Secondary } \\
\text { Vocational Education } \\
\text { Total }\end{array}$ & 0.183 & $-.485^{\prime \prime}$ & -0.092 & -0.014 & 0.001 & -0.171 & 0.079 \\
\hline Higher Education Men & $.218^{x}$ & -0.091 & $413^{-\infty}$ & 0.134 & $325^{\circ}$ & $628^{\approx}$ & 0.147 \\
\hline $\begin{array}{l}\text { Higher Education } \\
\text { Women }\end{array}$ & 0.101 & -0.018 & $.369^{\pi}$ & 0.147 & $262^{*}$ & $607^{*}$ & 0.069 \\
\hline $\begin{array}{l}\text { Higher Education } \\
\text { Total }\end{array}$ & 0.161 & -0.054 & $400^{\circ}$ & 0.144 & $299^{\prime \prime}$ & $632^{\prime \prime}$ & 0.109 \\
\hline $\begin{array}{l}\text { University Education } \\
\text { Men }\end{array}$ & 0.171 & -0.149 & $.398^{\prime \prime}$ & 0.156 & $347^{\prime \prime}$ & $631^{\prime \prime}$ & 0.107 \\
\hline $\begin{array}{l}\text { University Education } \\
\text { Women }\end{array}$ & 0.176 & -0.113 & $424^{x}$ & 0.143 & $.357^{*}$ & $660^{\circ}$ & 0.12 \\
\hline $\begin{array}{l}\text { University Education } \\
\text { Total }\end{array}$ & 0.174 & -0.132 & $412^{\circ}$ & 0.15 & $353^{\prime \prime}$ & $646^{\prime}$ & 0.113 \\
\hline
\end{tabular}

N-79

* Correlation is significant at the 0.01 level

* Correlation is significant at the 0.05 level 
Table 4: Socio-economic and 1998 electoral data - Pearson correlations

\begin{tabular}{|c|c|c|c|c|c|c|}
\hline & HZDS & $\begin{array}{l}\text { SMK- } \\
\text { MiKP }\end{array}$ & SDK & SNS & Sop & SDL \\
\hline Urban Population & $-.309^{\circ}$ & -0.156 & 582 & -0.103 & $.232^{\circ}$ & 0.142 \\
\hline $\begin{array}{l}\text { Gender - Men } \\
\text { Permanently residing } \\
\text { population }\end{array}$ & $478^{-1}$ & -0.135 & $-.461^{\approx}$ & $.278^{\infty}$ & -0.059 & $-.236^{*}$ \\
\hline $\begin{array}{l}\text { Gender - Women } \\
\text { Permanently residing } \\
\text { population }\end{array}$ & $-.475^{\circ}$ & 0.134 & $459^{-1}$ & $-.275^{\pi}$ & 0.058 & $237^{*}$ \\
\hline $\begin{array}{l}\text { Gender - Men } \\
\text { Economically active } \\
\text { population }\end{array}$ & $464=$ & 0.034 & $-.615^{*}$ & 0.146 & $-.217^{*}$ & -0.2 \\
\hline $\begin{array}{l}\text { Gender - Women } \\
\text { Economically active } \\
\text { population }\end{array}$ & $-.464=$ & -0.034 & $.615^{\prime \prime}$ & -0.146 & $217^{*}$ & 0.2 \\
\hline Hungarian Nationality & $-.615^{\prime \prime}$ & $.995^{\circ}$ & $-.232^{x}$ & $-.479^{-1}$ & -0.119 & $-.428^{\prime \prime}$ \\
\hline Unemployment & -0.085 & $.276^{\circ}$ & $-.490^{\circ}$ & $-.269^{\prime}$ & $.267^{*}$ & -0.016 \\
\hline $\begin{array}{l}\text { Work Force } \\
\text { Distribution } \\
\text { Industry } \\
\end{array}$ & $473^{\pi}$ & -0.187 & $-.403^{\pi}$ & $427^{-1}$ & $-.276^{\pi / 0}$ & -0.011 \\
\hline $\begin{array}{l}\text { Work Force } \\
\text { Distribution } \\
\text { Business }\end{array}$ & $-.299^{*}$ & 0.121 & $.351^{\circ}$ & -0.166 & 0.136 & -0.021 \\
\hline $\begin{array}{l}\text { Work Force } \\
\text { Distribution } \\
\text { Finance }\end{array}$ & $-.258^{x}$ & -0.013 & $497^{-1}$ & -0.132 & -0.043 & 0.019 \\
\hline $\begin{array}{l}\text { Work Force } \\
\text { Distribution } \\
\text { Real Estate }\end{array}$ & $-.458^{\infty}$ & -0.045 & $709^{-x}$ & -0.19 & 0.197 & 0.107 \\
\hline Age Group 25-34 Men & $501 \%$ & -0.091 & $-.579^{\pi}$ & $290^{\pi}$ & -0.051 & \\
\hline $\begin{array}{l}\text { Age Group } 25-34 \\
\text { Women }\end{array}$ & $-.501^{*}$ & 0.091 & $579^{-1}$ & $-.290^{*}$ & 0.051 & $227^{*}$ \\
\hline Age Group $35-44$ Men & $510^{\circ}$ & -0.033 & $-.581^{\prime \prime}$ & 0.206 & $-.262^{*}$ & -0.157 \\
\hline $\begin{array}{l}\text { Age Group } 35-44 \\
\text { Women }\end{array}$ & $-.510^{*}$ & 0.033 & $581^{\circ}$ & -0.206 & $.262^{*}$ & 0.157 \\
\hline Age Group 45-54 Men & $429^{\prime \prime}$ & -0.089 & $-.468^{\infty}$ & $268^{x}$ & -0.157 & -0.063 \\
\hline $\begin{array}{l}\text { Age Group } 45-54 \\
\text { Women }\end{array}$ & $-.429^{\circ}$ & 0.089 & $.458^{\infty}$ & $-.268^{*}$ & 0.157 & 0.063 \\
\hline $\begin{array}{l}\text { Age Group } 45.54 \\
\text { Total }\end{array}$ & $-.307^{\prime \prime}$ & 0.079 & $.351^{\circ}$ & -0.05 & -0.029 & 0.144 \\
\hline Age Group 55.59 Men & -0.122 & 0.096 & 0.135 & 0.021 & -0.061 & -0.114 \\
\hline $\begin{array}{l}\text { Age Group } 55-59 \\
\text { Women }\end{array}$ & 0.122 & -0.096 & -0.135 & -0.021 & 0.061 & 0.114 \\
\hline Age Group 1859 Men & $-.425^{=1}$ & 0.14 & $.382^{\circ}$ & -0.083 & 0.165 & 0.053 \\
\hline $\begin{array}{l}\text { Age Group } 18-59 \\
\text { Women }\end{array}$ & $-.382^{\infty}$ & 0.173 & $.299^{\pi}$ & -0.039 & 0.089 & 0.044 \\
\hline $\begin{array}{l}\text { Elementary Education } \\
\text { Women }\end{array}$ & 0.056 & $455^{\circ}$ & $-.648^{\pi}$ & -0.143 & $-.227^{*}$ & -0.143 \\
\hline $\begin{array}{l}\text { Elementary Education } \\
\text { Total }\end{array}$ & 0.033 & $433^{\prime \prime}$ & $-.606^{\circ}$ & -0.168 & -0.192 & -0.138 \\
\hline $\begin{array}{l}\text { Complete Secondary } \\
\text { Vocational Education } \\
\text { Men }\end{array}$ & 562 & $-.469^{\prime \prime}$ & $-.292^{\prime \prime}$ & $438^{-1}$ & 0.04 & 0.076 \\
\hline $\begin{array}{l}\text { Complete Secondary } \\
\text { Vocational Education } \\
\text { Women }\end{array}$ & $.613^{*}$ & $-.441^{\pi}$ & $-.294^{\pi}$ & $524^{-1}$ & $-.230^{\circ}$ & 0.15 \\
\hline $\begin{array}{l}\text { Complete Secondary } \\
\text { Vocational Education } \\
\text { Total }\end{array}$ & $613^{*}$ & $-.482^{-1}$ & $-.308^{*}$ & $497^{-1}$ & -0.071 & 0.111 \\
\hline Higher Education Men & $-.315^{\circ}$ & -0.099 & $.625^{\circ}$ & -0.033 & 1.031 & 0.108 \\
\hline $\begin{array}{l}\text { Higher Education } \\
\text { Women }\end{array}$ & $-.368^{*}$ & -0.028 & $.639^{\prime \prime}$ & -0.115 & 0.041 & 0.038 \\
\hline $\begin{array}{l}\text { Higher Education } \\
\text { Total }\end{array}$ & $-.350^{\circ}$ & -0.064 & $647=$ & -0.077 & 0.037 & 0.074 \\
\hline $\begin{array}{l}\text { University Education } \\
\text { Men }\end{array}$ & $-.331^{\prime \prime}$ & -0.157 & $692^{*}$ & -0.112 & 0.116 & 0.151 \\
\hline $\begin{array}{l}\text { University Education } \\
\text { women }\end{array}$ & $-.343^{\infty}$ & -0.122 & $.596^{\circ}$ & -0.127 & 0.076 & 0.123 \\
\hline $\begin{array}{l}\text { University Education } \\
\text { Total }\end{array}$ & $-.338^{-1}$ & -0.14 & $695^{\prime \prime}$ & & 0.097 & 0.138 \\
\hline
\end{tabular}

N-79

- Correlation is significant at the 0.01 level

* Correlation is significant at the 0.05 level 
Table 5: Socio-economic and 2002 electoral data - Pearson correlations

\begin{tabular}{|c|c|c|c|c|c|c|c|}
\hline & HZDS & $\begin{array}{l}\text { SMK- } \\
\text { MIKP }\end{array}$ & SDKU & KDH & SMER & ksS & ANO \\
\hline Urban Population & $-.266^{2}$ & -0.12 & $759^{\circ}$ & -0.136 & 0.031 & -.232 & $242^{7}$ \\
\hline $\begin{array}{l}\text { Gender - Men } \\
\text { Permanently residing } \\
\text { population }\end{array}$ & $465^{\circ}$ & -0.178 & $-.655^{\infty}$ & $432^{-1}$ & 0.167 & 0.157 & -0.138 \\
\hline $\begin{array}{l}\text { Gender - Women } \\
\text { Permanently residing } \\
\text { population }\end{array}$ & $-.464^{\pi}$ & 0.178 & $652^{\pi}$ & $-.432^{\prime \prime}$ & -0.169 & -0.156 & 0.138 \\
\hline $\begin{array}{l}\text { Gender - Men } \\
\text { Economically active } \\
\text { population }\end{array}$ & $455^{\circ}$ & -0.011 & $-.777^{\infty}$ & 0.189 & 0.118 & $344^{m}$ & $-.335^{\prime \prime}$ \\
\hline $\begin{array}{l}\text { Gender - Women } \\
\text { Economically active } \\
\text { population }\end{array}$ & $-.455^{\prime \prime}$ & 0.011 & $.777^{-1}$ & -0.189 & $-0.11 \mathrm{~g}$ & $-.344^{\pi}$ & 336 \\
\hline Hungarian Nationality & $-.562^{\prime \prime}$ & $991^{\prime \prime}$ & $-.230^{*}$ & $-.535^{\prime \prime}$ & $-.705^{\circ}$ & $-.299^{\prime \prime}$ & $-.255^{*}$ \\
\hline Unemployment & -0.127 & $262^{2}$ & $-.619^{n}$ & -0.031 & -0.188 & $428^{\circ}$ & $240^{\circ}$ \\
\hline $\begin{array}{l}\text { Work Force } \\
\text { Distribution } \\
\text { Industry }\end{array}$ & $483^{\prime \prime}$ & $-.224^{x}$ & $-.432 \%$ & 0.004 & $273^{*}$ & 0.159 & -0.202 \\
\hline $\begin{array}{l}\text { Work Force } \\
\text { Distribution } \\
\text { Business }\end{array}$ & $-.254^{x}$ & 0.155 & $459^{=}$ & -0.182 & -0.025 & $-.371^{m}$ & 0.085 \\
\hline $\begin{array}{l}\text { Work Force } \\
\text { Distribution } \\
\text { Finance }\end{array}$ & $-.248^{*}$ & 0.012 & $566^{\prime \prime}$ & 0.001 & $-.233^{*}$ & $-.221^{*}$ & -0.029 \\
\hline $\begin{array}{l}\text { Work Force } \\
\text { Distribution } \\
\text { Real Estate }\end{array}$ & $-.425^{\prime \prime}$ & 0.006 & $863^{\pi}$ & -0.129 & -0.048 & $-.383^{\prime \prime}$ & 0.153 \\
\hline Age Group $25-34$ Men & $482=$ & -0.125 & $-.675=$ & 0.208 & 0.099 & $258^{x}$ & -0.193 \\
\hline $\begin{array}{l}\text { Age Group } 2534 \\
\text { Women }\end{array}$ & $-.482 \pi$ & 0.125 & $675^{\circ}$ & -0.208 & -0.099 & $-.258^{x}$ & 0.193 \\
\hline Age Group $35-44$ Men & $491^{\circ}$ & -0.073 & $-.696^{\prime \prime}$ & 0.141 & 0.124 & $.328^{\prime \prime}$ & $-.292^{\prime \prime}$ \\
\hline $\begin{array}{l}\text { Age Group } 35-44 \\
\text { Women }\end{array}$ & $-.491^{\pi}$ & 0.073 & $696^{\prime \prime}$ & -0.141 & -0.124 & $-.328^{\pi}$ & $292^{21}$ \\
\hline Age Group 45-54 Men & $417^{-1}$ & -0.129 & $-.545^{\pi}$ & 0.106 & 0.206 & 0.18 & -0.157 \\
\hline $\begin{array}{l}\text { Age Group } 45-54 \\
\text { Women }\end{array}$ & $-.417^{\circ}$ & 0.129 & $545^{\prime \prime}$ & -0.106 & -0.206 & -0.18 & 0.157 \\
\hline $\begin{array}{l}\text { Age Group } 45-54 \\
\text { Total }\end{array}$ & $-.262^{x}$ & 0.109 & $544^{\pi}$ & $-.416^{\prime \prime}$ & -0.017 & $-.256^{*}$ & 0.022 \\
\hline Age Group 55.59 Men & -0.09 & 0.1 & 0.142 & -0.102 & -0.015 & $-.292^{\alpha}$ & -0.111 \\
\hline $\begin{array}{l}\text { Age Group } 55-59 \\
\text { Women }\end{array}$ & 0.09 & -0.1 & -0.142 & 0.102 & 0.015 & $292=$ & 0.111 \\
\hline Age Group $18-59$ Men & $-.373^{\prime \prime}$ & 0.169 & $547^{\prime \prime}$ & $-.324=$ & -0.044 & $-.383^{\prime \prime}$ & 0.164 \\
\hline $\begin{array}{l}\text { Age Group } 18-59 \\
\text { Women }\end{array}$ & $-.323^{\prime \prime}$ & 0.2 & $484=$ & $-.415^{\prime \prime}$ & -0.028 & $-.369^{\prime \prime}$ & 0.092 \\
\hline $\begin{array}{l}\text { Elementary Education } \\
\text { Women }\end{array}$ & 0.039 & $422^{-1}$ & $-.773^{\pi}$ & $-.225^{x}$ & -0.17 & $308^{*}$ & $-.229^{x}$ \\
\hline $\begin{array}{l}\text { Elementary Education } \\
\text { Total }\end{array}$ & 0.008 & $398^{\prime \prime}$ & $-.756=$ & -0.148 & -0.198 & $.315^{\prime \prime}$ & -0.183 \\
\hline $\begin{array}{l}\text { Complete Secondary } \\
\text { Vocational Education } \\
\text { Men }\end{array}$ & $539^{\pi}$ & $-.485^{\prime \prime}$ & $-.259^{\pi}$ & 0.191 & $421^{\pi}$ & $307^{\pi}$ & 0.015 \\
\hline $\begin{array}{l}\text { Complete Secondary } \\
\text { Vocational Education } \\
\text { Women }\end{array}$ & $598^{\prime \prime}$ & $-.474=$ & $-.301 \%$ & $216^{*}$ & $365^{\prime \prime}$ & 0.179 & -0.105 \\
\hline $\begin{array}{l}\text { Complete Secondary } \\
\text { Vocational Education } \\
\text { Total }\end{array}$ & $591^{\prime \prime}$ & $-.506^{\prime \prime}$ & $-.290^{\circ}$ & $211^{\pi}$ & $420^{\circ}$ & $270^{*}$ & -0.035 \\
\hline Higher Education Men & $-.299^{\prime \prime}$ & -0.06 & $804=$ & -0.139 & -0.104 & $-.314=$ & 0.078 \\
\hline $\begin{array}{l}\text { Higher Education } \\
\text { women }\end{array}$ & $-.365^{\prime \prime}$ & 0.013 & $784=$ & -0.065 & -0.153 & $-.331^{\pi}$ & 0.023 \\
\hline $\begin{array}{l}\text { Higher Education } \\
\text { Total }\end{array}$ & $-341^{\prime \prime}$ & -0.023 & $812=$ & -0.103 & -0.132 & $-.330 "$ & 0.051 \\
\hline $\begin{array}{l}\text { University Education } \\
\text { Men }\end{array}$ & $-.322^{\prime \prime}$ & -0.114 & $855^{\pi}$ & -0.061 & -0.075 & $-.276^{\prime \prime}$ & 0.139 \\
\hline $\begin{array}{l}\text { University Education } \\
\text { Women }\end{array}$ & $-.334=$ & -0.08 & $.855^{\prime \prime}$ & -0.071 & -0.105 & $-.305^{\prime \prime}$ & 0.088 \\
\hline $\begin{array}{l}\text { University Education } \\
\text { Total }\end{array}$ & $-.328^{*}$ & -0.098 & $857 \approx$ & -0.066 & -0.089 & $-.290^{\pi}=$ & 0.115 \\
\hline
\end{tabular}

N-79

* Correlation is significant at the 0.01 level

*t Correlation is significant at the 0.05 level 
Proposition 1: Less educated voters are inclined to vote for the post-communist/populist parties.

In the 1994 electoral contest, the strongest positive correlations between less educated voters and the parties were those for the Hungarian party $M K$ and the strongest negative coefficient with the pro-reform $D U$. In the 1998 election, voters with completed secondary vocational education showed a strong correlation with support for postcommunist/populist parties such as $H Z D S$ and SNS. Furthermore, in the 2002 contest, this trend continued and voters with completed secondary vocational education demonstrated a positive correlation again with support for $H Z D S$.

According to survey data (Table 6), in the 1998 parliamentary election HZDS, $S M K-M K P$ and $S N S$ drew most of their supporters from among people with primary education $(51.3 \%, 40.2 \%$ and $34.6 \%)$. Another populist party, $S D L$, had equal representation among people with primary education and high school education without leaving examinations $(31.5 \%)$.

Table 6: Voting preferences according to voters' education level (in \%)

\begin{tabular}{|l|l|l|l|l|l|l|}
\hline $\begin{array}{l}\text { Education Level/ } \\
\text { Political Party }\end{array}$ & HZDS & SDK & SDL & $\begin{array}{l}\text { SMK- } \\
\text { MKP }\end{array}$ & SNS & SOP \\
\hline Primary & 51.3 & 18.4 & 25.4 & 40.2 & 34.6 & 15.5 \\
\hline $\begin{array}{l}\text { High School without } \\
\text { leaving examinations } \\
\text { apprentice) }\end{array}$ & 26.7 & 30.3 & 31.5 & 32.9 & 32.1 & 38.0 \\
\hline $\begin{array}{l}\text { High School with } \\
\text { leaving examinations } \\
\text { (upper secondary) }\end{array}$ & 17.5 & 37.6 & 31.5 & 23.2 & 28.2 & 38.0 \\
\hline University & 4.6 & 13.7 & 11.5 & 3.7 & 5.1 & 8.5 \\
\hline
\end{tabular}

Source: FOCUS (1998). 
In addition, as Table 7 demonstrates, in the 1998 electoral contest HZDS's supporters were mostly among qualified (17.5\%) and not-qualified (13.3\%) manual workers, which is understandable since people that voted for $H Z D S$ were predominantly among those with the primary level of education. Other populist or left parties, such as $S N S$ and $S D L$, received the majority of their support from qualified manual workers (30.8\% and $24.6 \%$ ), and by executive specialized workers (20.5\% and $18.5 \%)$. Thus, survey data confirmed correlation findings based on aggregate data for the 79 districts that less educated voters are inclined to vote for opposition parties.

Table 7: Voting preferences according to voters' type of employment (in \%)

\begin{tabular}{|l|l|l|l|l|l|l|}
\hline $\begin{array}{l}\text { Employment / } \\
\text { Political Party }\end{array}$ & $\begin{array}{l}\text { HZ } \\
\text { DS }\end{array}$ & SDK & SDL' & $\begin{array}{l}\text { SMK- } \\
\text { MKP }\end{array}$ & SNS & SOP \\
\hline $\begin{array}{l}\text { Not-qualified } \\
\text { manual worker }\end{array}$ & 13.3 & 3.8 & 8.5 & 15.9 & 12.8 & 5.6 \\
\hline $\begin{array}{l}\text { Qualified manual } \\
\text { worker }\end{array}$ & 17.5 & 20.9 & 24.6 & 15.9 & 30.8 & 26.8 \\
\hline $\begin{array}{l}\text { Executive } \\
\text { specialized } \\
\text { worker }\end{array}$ & 9.6 & 26.1 & 18.5 & 15.9 & 20.5 & 26.8 \\
\hline $\begin{array}{l}\text { Creative } \\
\text { specialized } \\
\text { worker }\end{array}$ & 3.3 & 12.0 & 6.9 & 3.7 & 3.8 & 7.0 \\
\hline Director & 2.5 & 6.8 & 1.5 & 2.4 & 3.8 & 2.8 \\
\hline $\begin{array}{l}\text { Entrepreneur } \\
\text { without } \\
\text { employees }\end{array}$ & 0.9 & 0.8 & & & & \\
\hline
\end{tabular}

Source: FOCUS (1998). 
Proposition 2: Voters with higher education are more likely supportive of pro-reform parties.

In the 1994 election, across the 79 districts there was a positive correlation between voters with higher and university education and support for the main pro-reform party Spoločná Vol'ba and an even stronger correlation with the other principal proreform party, $D U$. That is, districts wherein the population was relatively better educated tended to vote pro-reform. This trend persisted in the 1998 and 2002 contest as illustrated by strong correlations between voters with higher and university levels of education and their support for the pro-reform $S D K / S D K U$. In addition, the strength of this particular correlation increased over time.

As survey studies confirm (Table 6), in the 1998 election SDK had most of its voters among people that graduated from high school with school leaving examinations (37.6\%). In comparison to other political parties $S D K$ received the highest preferences from voters with a university education (13.7\%). Another pro-reform political party, $S O P$, had equal representation among people with primary education and high school without leaving examinations (38.0\%). The Hungarian Coalition SMK-MKP had the majority of its voters among people with primary education (40.2\%). Since SDK had the majority of its voters among people with the highest education levels, it is apparent that the party received most of its preferences from people in executive specialized positions (26.1\%) (Table 7). Furthermore, the Hungarian Coalition $S M K-M K P$ was equally supported not only by not-qualified and qualified manual workers, but also by executive specialized workers (15.9\%), illustrating that support for this ethnic party was vertical 
(i.e., regardless of educational attainment levels). Thus, the survey data are in agreement with statistical correlations based on aggregate data that voters with higher education are more likely supportive of pro-reform parties. Making the point another way, correlation coefficients between the populist or post-communist parties and higher education are negative or very weakly positive.

Proposition 3: Younger voters tend to vote for pro-reform political parties.

As Tables 3-5 demonstrate, there was a positive correlation between younger women voters in the age group 25-34 and the pro-reform Spoločná Vol'ba and $D U$ in the 1994 contest. There was a continuing strong relationship between younger women voters in age group 24-34 and the pro-reform parties SDK/ SDKÚ in the 1998 and 2002 election. There was an increase in the strength of this correlation from 1998 to 2002 election. Furthermore, younger men voters in the age group 24-34 and the populist HZDS showed a positive correlation in the 1998 and 2002 contest.

Table 8: Voting preferences according to voters' age (in \%)

\begin{tabular}{|l|l|l|l|l|l|l|}
\hline $\begin{array}{l}\text { Age / } \\
\text { Political } \\
\text { Party }\end{array}$ & HZDS & SDK & SDL & $\begin{array}{l}\text { SMK- } \\
\text { MKP }\end{array}$ & SNS & SOP \\
\hline $18-24$ & 6.3 & 15.0 & 14.6 & 13.4 & 12.8 & 11.3 \\
\hline $25-34$ & 13.8 & 32.1 & 22.3 & 20.7 & 32.1 & 31.0 \\
\hline $35-44$ & 17.5 & 25.2 & 20.8 & 19.5 & 17.9 & 22.5 \\
\hline $45-54$ & 16.3 & 12.0 & 17.7 & 17.1 & 15.4 & 16.9 \\
\hline $55-59$ & 9.2 & 3.0 & 6.2 & 7.3 & 6.4 & 5.6 \\
\hline 60 and higher & 37.1 & 12.8 & 18.5 & 22.0 & 15.4 & 12.7 \\
\hline
\end{tabular}

Source: FOCUS (1998). 
According to survey data (Table 8), in the 1998 election SDK had the youngest supporters, with the majority of them being in the age group 18-24 (15.0\%) and 25-34 (32.1\%). SMK-MKP was preferred by younger voters in the age group 25-34 (20.7\%), but also received strong support from voters in the age group 60 and higher. Another proreform party, $S O P$, had similarly to $S D K$ the majority of its supporters in the age group 25-34 (31\%). Left parties $S D L$ ' and SNS also had strong support among younger voters in the age group 25-34 (22.3\% and 32.1\%). As illustrated in Table 9, among all participating parties, the pro-reform $S D K$ and $S O P$ had strong support among households with young people $(5.1 \%$ and $5.6 \%)$ and in young households (13.7\% and $18.3 \%)$.Overall, both correlations and survey data confirm that younger voters tend to vote mainly for proreform political parties.

Table 9: Voting preferences according to voters' household (in \%)

\begin{tabular}{|l|l|l|l|l|l|l|}
\hline $\begin{array}{l}\text { Type of } \\
\text { household/ } \\
\text { Political Party }\end{array}$ & HZDS & SDK & SDL & $\begin{array}{l}\text { SMK- } \\
\text { MKP }\end{array}$ & SNS & SOP \\
\hline Young people & 2.1 & 5.1 & 3.8 & 3.7 & 5.1 & 5.6 \\
\hline Young household & 7.5 & 13.7 & 10.8 & 18.3 & 14.1 & 18.3 \\
\hline $\begin{array}{l}\text { Ordinary } \\
\text { household }\end{array}$ & 17.5 & 29.5 & 23.8 & 17.1 & 17.9 & 25.4 \\
\hline Adult household & 16.3 & 29.5 & 26.9 & 20.7 & 37.2 & 22.5 \\
\hline $\begin{array}{l}\text { Three generations } \\
\text { household }\end{array}$ & 12.9 & 4.7 & 6.9 & 9.8 & 7.7 & 12.7 \\
\hline Older household & 11.7 & 6.4 & 12.3 & 9.8 & 7.7 & 7.0 \\
\hline Older people & 30.4 & 9.8 & 13.1 & 20.7 & 10.3 & 8.5 \\
\hline Other & 1.7 & 1.3 & 2.3 & & & \\
\hline
\end{tabular}

Source: FOCUS (1998). 
Proposition 4: Older voters are more inclined to vote for opposition parties and/or parties that are on the left of the political spectrum.

Somewhat surprisingly, statistical correlations of older voters in the age groups 55-59 and 60 and higher did not reveal any significant relationships with voting for parties of the political left, or any parties for that matter. There are probably two reasons why aggregate data did not support this proposition. The first reason is that there is an insufficient variation in the Slovak age structure. The second reason is that the data are not disaggregated enough to produce strong correlation. For example, rural elderly may be voting differently than urban elderly. However, according to survey studies, HZDS had the majority of its support in the 1998 electoral contest from older voters in the age group of 60 and higher (37.1\%) and 55-59 (9.2\%) (Table 8). In addition, as demonstrated in Table 6, voters living in older households were also voting for the populist parties $S D L^{\prime}$ (12.3\%) and $H Z D S(11.7 \%)$. Furthermore, $H Z D S$ and $S D L^{\prime}$ had the highest share of their support in households with older people (30.4\% and 13.1\%). The pro-reform SMK-MKP was also supported by voters living in households with older people (20.7\%), which is understandable since the Hungarian Coalition had most of their supporters among people of age 60 and higher (Table 8). Therefore, according to the individual level data, overall older voters were more inclined to vote for opposition parties and/or parties that are on the left of the political spectrum. 
Proposition 5: Ethnic Hungarian voters favor parties explicitly representing the interests of the Hungarian minority.

Ethnic Hungarians continuously illustrated the strongest correlation with $M K / S M K-M K P$, the parties explicitly representing the interests of Slovakia's ethnic Hungarian minority in all three electoral contests. Indeed, the bivariate coefficients for percent ethnic Hungarian and the percentage of the vote for the $M K / S M K-M K P$ are the highest of any statistical relationship in this study, illustrating how dramatic the ethnic cleavage is in the Slovak electorate. As survey studies illustrate (Table 10), this is consistent with the individual level data on the nationality indicator of voters in the 1998 parliamentary election. From six political parties and movements chosen to the parliament, the Hungarian Coalition $S M K-M K P$ received most of their votes from people of the Hungarian nationality (93.9\%). All other five political parties and movements had the majority of their supporters among Slovak nationals. Thus, both the aggregate statistical correlations and survey data demonstrate that voters with Hungarian nationality vote for parties that explicitly represent the interests of the Hungarian minority.

Table 10: Voting preferences according to voters' nationality (in \%)

\begin{tabular}{|l|l|l|l|l|l|l|}
\hline $\begin{array}{l}\text { Nationality / } \\
\text { Political } \\
\text { Party }\end{array}$ & HZDS & SDK & SDL & $\begin{array}{l}\text { SMK- } \\
\text { MKP }\end{array}$ & SNS & SOP \\
\hline Slovak & 95.0 & 95.3 & 90.0 & 6.1 & 98.7 & 93.0 \\
\hline Hungarian & 0.8 & 3.4 & 1.5 & 93.9 & & 4.2 \\
\hline Other & 4.2 & 1.3 & 8.5 & & 1.3 & 2.8 \\
\hline
\end{tabular}

Source: FOCUS (1998). 
Proposition 6: Voters living in districts with high unemployment rates are likely to vote for populist or post-communist political parties and not for the pro-reform parties.

High unemployment rates were negatively correlated with electoral votes for the pro-reform Spoločna Vol'ba and $D U ́$ in the 1994 election and with the pro-reform $S D K / S D K U$ in the 1998 and 2002 parliamentary contests, indicating that voters in areas of higher unemployment opted for populist or leftist parties that promised more secure employment. This is confirmed by the fact that high unemployment rates were positively correlated with the post-communist KSS in the 2002 election. As survey data illustrate (Table 11), household income is a useful indicator of voters' economic situation. As mentioned before, SDK's voters had the highest level of education, mostly among executive specialized workers, therefore they also had the highest rates of income in the group earning $5000 \mathrm{Sk}$ and more (32.5\%). The leftist party SDL had supporters mainly among qualified manual workers and executive specialized workers, therefore their voters' household income is represented in two groups - $5000 \mathrm{Sk}$ and higher (23.1\%) and 3000-3999 Sk (21.5\%). The populist HZDS and the ethnic Hungarian SMK-MKP had many supporters among people with low levels of education, thus their total income was also low, from 3000-3999 Sk (22.9\% and 41.5\%). Furthermore, people who voted proreform SOP and for the left party SDL' live in the household with income of 5000 Sk and more $(28.2 \%$ and $23.1 \%)$. 
Table 11: Voting preferences according to voters' household income (in \%)

\begin{tabular}{|c|c|c|c|c|c|c|}
\hline $\begin{array}{l}\text { Household } \\
\text { Income } \\
\text { Political Party }\end{array}$ & HZDS & SDK & SDL & $\begin{array}{l}\text { SMK- } \\
\text { MKP }\end{array}$ & SNS & SOP \\
\hline $1-2000 \mathrm{Sk}$ & 4.2 & 1.7 & 1.5 & 3.7 & 1.3 & \\
\hline 2000-2999 Sk & 17.1 & 12.0 & 13.8 & 9.8 & 12.8 & 14.1 \\
\hline $3000-3999 \mathrm{Sk}$ & 22.9 & 18.8 & 21.5 & 41.5 & 23.1 & 21.1 \\
\hline $4000-4999 \mathrm{Sk}$ & 17.5 & 15.4 & 16.9 & 18.3 & 11.5 & 7.0 \\
\hline $5000 \mathrm{Sk}$ and more & 15.8 & 32.5 & 23.1 & 12.2 & 21.8 & 28.2 \\
\hline Do not want say & 15.4 & 8.5 & 11.5 & 12.2 & 20.5 & 21.1 \\
\hline Don't know & 7.1 & 11.1 & 11.5 & 2.4 & 9.0 & 8.5 \\
\hline
\end{tabular}

Source: FOCUS (1998).

Overall, both survey data and statistical correlations agree that voters living in districts with high unemployment rates and those with low household income are likely to vote for populist or left political parties.

Proposition 7: Pro-reform parties tend to be more supported in urban areas.

In all three elections, pro-reform political parties evinced positive correlation coefficients, in some cases strongly so, with the level of urbanization variable, indicating that their support was strongest in urban areas. Specifically, there was a strong correlation between the urban variable and electoral votes for the pro-reform $D U$ in the 1994 contest and for $S D K / S D K U$ in the 1998 and 2002 elections. Furthermore, the strength of the urban correlation with pro-reform political parties increased over time.

According to 1998 survey data (Table 12), the pro-reform SDK and SOP were mostly supported by voters living in urban areas, especially in the cities of Bratislava and 
Košice (20.9\%). On the other hand, the Hungarian Coalition SMK-MKP received most of its votes from people living in small communities of 1-2 thousand inhabitants (39.0\%). This is understandable since $S M K-M K P$ supporters are concentrated in the districts located along Hungarian border which are predominantly rural. From the populist or left parties, the SDL had the majority of its supporters from communities of 20-50 thousand inhabitants (20.8\%) and from communities of 5-20 thousand inhabitants (16.9\%), HZDS was almost equally represented in all types of communities, but with prevalence in small communities of 1-2 thousand inhabitants $(18.3 \%)$, whereas $S N S$ received most of their votes from people living in communities of $2-5$ thousand (20.5\%). As a result of both statistical correlations and survey data, we can conclude that pro-reform political parties tend to be better supported in urban areas.

Table 12: Voting preferences according to voters' size of community (in \%)

\begin{tabular}{|l|l|l|l|l|l|l|}
\hline $\begin{array}{l}\text { Size of } \\
\text { Community/ } \\
\text { Political Party }\end{array}$ & HZDS & SDK & SDL & $\begin{array}{l}\text { SMK- } \\
\text { MKP }\end{array}$ & SNS & SOP \\
\hline Less than 1000 & 11.3 & 7.3 & 10.8 & 20.7 & 11.5 & 7.0 \\
\hline $1000-2000$ & 18.3 & 15.4 & 13.8 & 39.0 & 11.5 & 22.5 \\
\hline $2000-5000$ & 17.5 & 16.2 & 5.4 & 14.6 & 20.5 & 11.3 \\
\hline $5000-20,000$ & 16.3 & 16.2 & 16.9 & 17.1 & 14.1 & 8.5 \\
\hline $20,000-50,000$ & 15.0 & 11.1 & 20.8 & 4.9 & 17.9 & 8.5 \\
\hline $50,000-100,000$ & 11.7 & 12.8 & 15.4 & & 14.1 & 14.1 \\
\hline BA, KE & 10.0 & 20.9 & 16.9 & 3.7 & 10.3 & 28.2 \\
\hline
\end{tabular}

Source: FOCUS (1998). 


\section{Proposition 8: Women voters tend to vote for pro-reform political parties.}

In all three elections, pro-reform parties received significant support from women voters. In 1994, there was a positive correlation between women voters and the proreform $D U$. This trend continued in the 1998 and 2002 contests with strong correlations between women voters and the pro-reform $S D K / S D K U$. Furthermore, the strength of this particular correlation strengthened over time. Also worthy of note is the negative relationship between female voters and the HZDS in 1998 and 2002, indicating that the stridency of Mečiar's message was not well received by women.

According to survey studies, from six political parties and movements that received enough votes to enter the parliament in the 1998 election, only HZDS and SNS received major support from men. The other four political parties and movements had the majority of their voters from the female population. While in the case of HZDS, SMK$M K P$, and $S O P$ the difference in male and female preferences was not large, on the other hand, $S N S, S D K$, and $S D L$ ' exhibited large differences in the numbers of voters of each sex (Table 13). SDK was the only political party in the 1998 election that explicitly addressed women's issues in its political program, therefore we can suggest that thanks to their attention to women's issues they received more preferences from female voters. Based on available survey data and statistical correlations we can conclude that women voters tend to vote for pro-reform political parties. 
Table 13: Voting preferences by gender (in \%)

\begin{tabular}{|l|l|l|l|l|l|l|}
\hline $\begin{array}{l}\text { Gender } \\
\text { Political } \\
\text { Party }\end{array}$ & HZDS & SDK & SDL & $\begin{array}{l}\text { SMK- } \\
\text { MKP }\end{array}$ & SNS & SOP \\
\hline Men & 51.3 & 43.2 & 41.5 & 47.6 & 60.3 & 46.5 \\
\hline Women & 48.8 & 56.8 & 58.5 & 52.4 & 39.7 & 53.5 \\
\hline
\end{tabular}

Source: FOCUS (1998).

Proposition 9: Pro-reform parties are the ones who explicitly supported European Union membership.

On May 16-17, 2003 Slovakia held a referendum on EU membership. The question all participants were asked was: Do you agree to the proposal that the Slovak Republic should become a member state of the European Union? $52.2 \%$ of eligible Slovak citizens participated in the referendum of which $92.5 \%$ were in favor of EU membership (Statistical Office of the Slovak Republic 1993).

According to regional distribution of support for EU membership, the highest percentage of votes were in districts of Bratislava and Košice as well as in districts of Dunajská Streda and Komárno (Figure 23). As indicated by regional voting data, all four districts were the strongholds of the pro-reform political parties (the Slovak Democratic Coalition and the Hungarian Coalition) in all three parliamentary elections. In contrast, districts that had the highest rate of vote against EU membership (Figure 24) were in the areas that voted for the populist HZDS in 1994, 1998, and 2002 contest. Therefore, regional vote for pro-reform political parties represented a shadow vote for EU membership. 
Figure 23: Share of the number of participants in the referendum who answered - yes

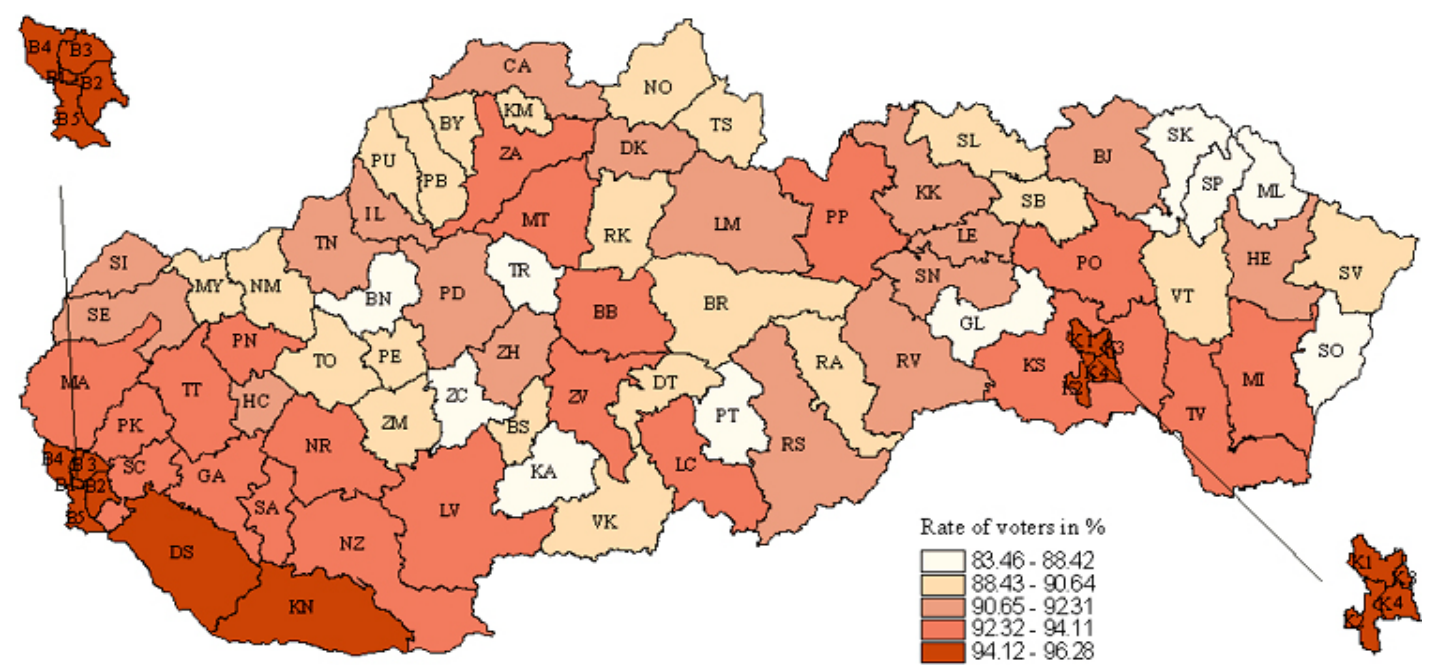

Source: Statistical Office of the Slovak Republic (2003a).

http://portal.statistics.sk/ref_2003/webdata/en/graf/kart2_a.htm. 
Figure 24: Share of the number of participants in the referendum who answered - no

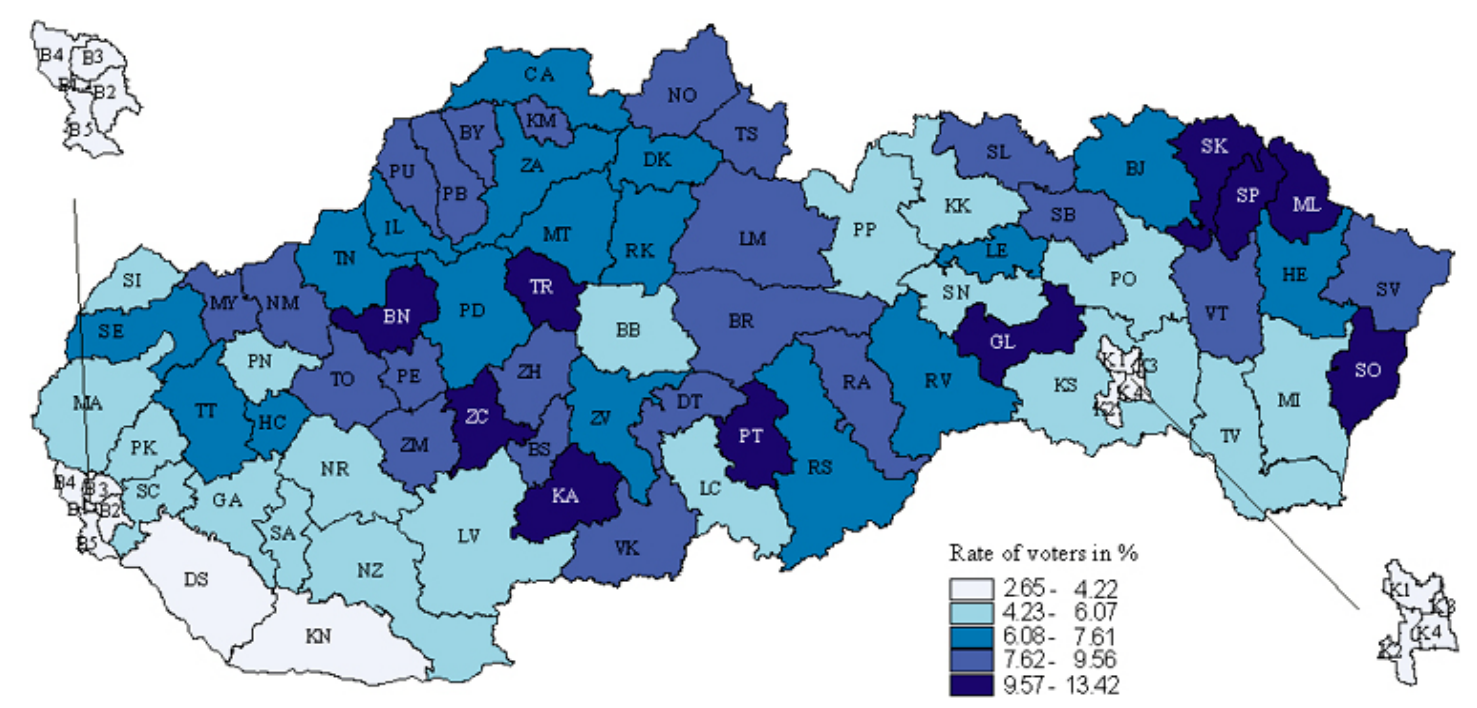

Source: Statistical Office of the Slovak Republic (2003b).

http://portal.statistics.sk/ref_2003/webdata/en/graf/kart3_a.htm.

The 2002 survey data on the European Union membership indicate that less educated voters with elementary education (31.0\%) and high school without leaving examinations education (31.0\%); older voters, especially those in age group 60 and higher (39\%); unqualified workers (34\%); respondents living in communities of 2-10 thousand people (39\%) and 50-100 thousand people (31\%); residents of Trenčiansky region; supporters of the Communist Party of Slovakia (50\%), the Movement for a Democratic Slovakia (49\%), the Slovak National Party (41\%), and the Party of the Democratic Left (41\%), were not supportive of Slovakia becoming a member of EU. In contrast, people with higher levels of education- completed secondary education $(77 \%)$ and university education (86\%); Hungarian nationals (79\%); younger voters in groups 18-24 (76\%) and 25-29 (79\%); residents living in communities with over 100 thousand 
people, especially in Bratislavský (83\%) and Košický (76\%) regions which include two largest cities Bratislava and Košice; entrepreneurs (81\%); supporters of the Slovak Democratic and Christian Union (95\%), Alliance of New Citizen (90\%), The Christian Democratic Movement (83\%), and SMER (79\%) were in favor of EU membership (Škrabala 2002b: 2). Overall, both voting and survey data confirm that pro-reform parties are the ones who explicitly supported European Union membership.

\section{Stepwise Regression}

Recognizing that both conceptually and empirically there is strong evidence indicating multicolinearity among the socio-economic variables themselves, a stepwise regression analysis was performed to determine which among a basket of associated variables offered the best (or most parsimonious) explanation for variations in the vote for the major parties in the Slovak elections of 1994, 1998, and 2002. That is, in the literature and in the bivariate correlations it is understood or can be shown that socioeconomic variables such as the level of urbanization, educational attainment, and age groups tend to cluster together; in other words, more urbanized areas typically evince higher educational levels and younger populations. To test this proposition, sets of socioeconomic variables were regressed against the percentage of the vote in each of the 79 districts for the leading pro-reform party in each election (Spoločná Vol'ba-1994, SDK1998, and $S D K U ́-2002)$ and the main populist party (HZDS throughout) as the dependent variables using the forward exclusion method. Variables to be tested in this procedure were drawn from those with the strongest bivariate correlations with the understanding that these, as discussed above, also are well established in the literature as good 
predictors of political party preference in post-communist elections, and are backed up with results from surveys. Specifically, the variables included are: level of urbanization (and percent rural), gender, unemployment levels, age groups, and levels of educational attainment. This method iteratively (i.e., "stepwise") considers variables to be brought into the regression equation to determine if they add significantly to the explanation. If a variable does so, it is included, and if not, it is excluded. The results are presented in Tables 14, 15, and 16 .

Looking at the most recent (2002) election first, it can be seen that the attainment of university level education and the percentage of the population in younger adult ages (18-24) explain a high percentage $\left(\mathrm{R}^{2}\right)$ of the variation in voting for the pro-reform $S D K U$ and, not surprisingly, relatively lower educational attainment, a higher percentage of men, higher levels of unemployment and a more rural population contribute the most to explaining variations in the $H Z D S$ vote among the districts. Precisely the same two variables are the strongest among the basket for the pro-reform $S D K$ in 1998 as for the $S D K U ́$ in 2002, although the statistical relationship is weaker. Again, the lower educational attainment and a higher percentage of men variables play the most prominent role in explaining the $H Z D S$ vote in 1998. The results for the 1994 election present something of a quandary, as the unemployment level variable is the strongest for both the pro-reform Spoločná Vol'ba and the populist HZDS (although in the case of HZDS the rural population variable is also retained). It may be the case here that in the immediate aftermath of Slovakia's independence, which was accompanied by severe economic turbulence and generally high unemployment, that districts in which other variables might have been important (e.g., level of urbanization and higher educational attainment) 
in shaping the pro-reform vote also had high unemployment levels, and pro- $H Z D S$ areas likewise (remembering that higher unemployment levels are positively associated with the $H Z D S$ vote in the later elections). The presence of another pro-reform party in 1994, $D U^{\prime}$, may also have affected how unemployment related to voting. As the electorate "matured" politically and the different parties solidified their respective bases, and the socio-economic landscape of Slovakia changed with the improving economy, employment conditions in the pro-reform districts improved and therefore the unemployment variable ceased to be important, but remained a crucial support element for the populist $H Z D S$. In summary, the stepwise regression analysis largely validates the individual bivariate relationships discussed above in detail and highlights the importance of certain variables for the pro-reform and populist parties, with the one exception of the unemployment variable and the pro-reform Spoločná Vol'ba in 1994.

Table 14: Stepwise regression - 2002 election

\begin{tabular}{|l|c|c|c|c|}
\hline \multicolumn{5}{|c|}{ Dependent Variable: SDKU (Pro-Reform) } \\
Model Summary
\end{tabular}

\footnotetext{
${ }^{12}$ Variables used: gender-men, gender-women, urban population, unemployment, age group 18-24, age group 25-34, and university education.
} 


\begin{tabular}{|c|c|c|c|c|}
\hline \multicolumn{5}{|c|}{$\begin{array}{c}\text { Dependent Variable: HZDS (Populist) } \\
\text { Model Summary }{ }^{13}\end{array}$} \\
\hline Model & $\mathbf{R}$ & R Square & $\begin{array}{l}\text { Adjusted R } \\
\text { Square }\end{array}$ & $\begin{array}{l}\text { Std. Error of the } \\
\text { Estimate }\end{array}$ \\
\hline $\begin{array}{l}\text { Education - Secondary } \\
\text { Professional without } \\
\text { High School Exam } \\
(\text { EDU_CSV_T) }\end{array}$ & $.579^{\mathrm{a}}$ & .335 & .326 & 7.2456 \\
\hline $\begin{array}{l}\text { Gender - Men } \\
\text { (GENDER_PRP_M) }\end{array}$ & $.630^{\mathrm{b}}$ & .397 & .381 & 6.9431 \\
\hline $\begin{array}{l}\text { Unemployment } \\
\text { (UNEMPLOYMENT) }\end{array}$ & $.660^{\mathrm{c}}$ & .436 & .413 & 6.7599 \\
\hline $\begin{array}{l}\text { Rural Population } \\
\text { (RUR_POP) }\end{array}$ & $.689^{d}$ & .475 & .447 & 6.5657 \\
\hline \multicolumn{5}{|c|}{$\begin{array}{l}\text { a. Predictors: (Constant), EDU_CSV_T } \\
\text { b. Predictors: (Constant), EDU_CSV_T, GENDER_PRP_M } \\
\text { c. Predictors: (Constant), EDU_CSV_T, GENDER_PRP_M, UNEMPLOYMENT } \\
\text { d. Predictors: (Constant), EDU_CSV_T, GENDER_PRP_M, UNEMPLOYMENT, RUR_POP }\end{array}$} \\
\hline
\end{tabular}

Table 15: Stepwise regression - 1998 election

\begin{tabular}{|c|c|c|c|c|}
\hline \multicolumn{5}{|c|}{$\begin{array}{c}\text { Dependent Variable: HZDS (Populist) } \\
\text { Model Summary }^{14}\end{array}$} \\
\hline Model & $\mathbf{R}$ & R Square & $\begin{array}{l}\text { Adjusted R } \\
\text { Square }\end{array}$ & $\begin{array}{l}\text { Std. Error of the } \\
\text { Estimate }\end{array}$ \\
\hline $\begin{array}{l}\text { Education - Secondary } \\
\text { Professional without } \\
\text { High School Exam } \\
\text { (EDU_CSV_T) }\end{array}$ & $.599^{\mathrm{a}}$ & .359 & .351 & 8.7485 \\
\hline $\begin{array}{l}\text { Gender - Men } \\
\text { (GENDER_EAP_M) }\end{array}$ & $.695^{\mathrm{b}}$ & .482 & .469 & 7.9134 \\
\hline $\begin{array}{l}\text { Education - Elementary } \\
(\text { EDU_ELEM_T) }\end{array}$ & $.735^{\mathrm{c}}$ & .540 & .521 & 7.5133 \\
\hline \multicolumn{5}{|c|}{$\begin{array}{l}\text { a. Predictors: (Constant), EDU_CSV_T } \\
\text { b. Predictors: (Constant), EDU_CSV_T, GENDER_EAP_M } \\
\text { c. Predictors: (Constant), EDU_CSV_T, GENDER_EAP_M, EDU_ELEM_T }\end{array}$} \\
\hline
\end{tabular}

\footnotetext{
${ }^{13}$ Variables used: gender-men, gender-women, rural population, unemployment, age group 55-59, age group 60 plus, elementary education, and education -secondary professional without high school exam. ${ }^{14}$ Variables used: gender-men, gender-women, rural population, unemployment, age group 55-59, age group 60 plus, elementary education, and education -secondary professional without high school exam.
} 


\begin{tabular}{|c|c|c|c|c|}
\hline \multicolumn{5}{|c|}{$\begin{array}{c}\text { Dependent Variable: SDK (Pro-Reform) } \\
\text { Model Summary }\end{array}$} \\
\hline Model & $\mathbf{R}$ & R Square & $\begin{array}{l}\text { Adjusted R } \\
\text { Square }\end{array}$ & $\begin{array}{l}\text { Std. Error of the } \\
\text { Estimate }\end{array}$ \\
\hline $\begin{array}{l}\text { University Education } \\
\text { (EDU_UNIV_T) }\end{array}$ & $.686^{\mathrm{a}}$ & .471 & .464 & 7.0079 \\
\hline $\begin{array}{l}\text { Age Group 18-24 } \\
\text { (AGE_18_24_T) }\end{array}$ & $.722^{\mathrm{b}}$ & .522 & .509 & 6.7039 \\
\hline \multicolumn{5}{|c|}{$\begin{array}{l}\text { a. Predictors: (Constant), EDU_UNIV_T } \\
\text { b. Predictors: (Constant), EDU UNIV T, AGE } 18 \quad 24 \text { T }\end{array}$} \\
\hline
\end{tabular}

Table 16: Stepwise regression - 1994 election

\begin{tabular}{|l|c|c|c|c|}
\hline \multicolumn{5}{|c|}{ Dependent Variable: SP_VOLBA (Pro-Reform) } \\
Model Summary
\end{tabular}

\begin{tabular}{|c|c|c|c|c|}
\hline \multicolumn{5}{|c|}{$\begin{array}{c}\text { Dependent Variable: HZDS_RSS (Populist) } \\
\text { Model Summary }^{17}\end{array}$} \\
\hline Model & $\mathbf{R}$ & R Square & $\begin{array}{l}\text { Adjusted R } \\
\text { Square }\end{array}$ & $\begin{array}{l}\text { Std. Error of the } \\
\text { Estimate }\end{array}$ \\
\hline Unemployment & $.600^{\mathrm{a}}$ & .360 & .352 & 15.2792 \\
\hline $\begin{array}{l}\text { Rural Population } \\
\text { (RUR_POP) }\end{array}$ & $.629^{\mathrm{b}}$ & .396 & .380 & 14.9444 \\
\hline \multicolumn{5}{|c|}{$\begin{array}{l}\text { a. Predictors: (Constant), UNEMPLOYMENT } \\
\text { b. Predictors: (Constant), UNEMPLOYMENT, RUR_POP }\end{array}$} \\
\hline
\end{tabular}

In summary, this statistical analysis of electoral and socio-economic data and the 1998 and 2002 survey data revealed that, with one important exception, relationships that we originally predicted were confirmed and continuous trends in these patterns generally

\footnotetext{
${ }^{15}$ Variables used: gender-men, gender-women, urban population, unemployment, age group 18-24, age group 25-34, and university education.

${ }^{16}$ Variables used: gender-men, gender-women, urban population, unemployment, age group 18-24, age group 25-34, and university education.

${ }^{17}$ Variables used: gender-men, gender-women, rural population, unemployment, age group 55-59, age group 60 plus, elementary education, and education -secondary professional without high school exam.
} 
strengthened over time. This study validates the view that voters' electoral choices are shaped by socio-demographic variables such as age, gender, education, nationality, unemployment, and urban/rural residence. The analysis also illustrated that welleducated, young, urban voters tend to vote for pro-reform political parties and were supportive of Slovakia joining EU, whereas elderly, less educated, rural voters were more inclined to vote for the left-wing parties and were against EU membership. 


\section{CHAPTER V}

\section{CONCLUSION}

This study describes and analyzes regional variations in voting behavior in postcommunist Slovakia during the 1994, 1998, and 2002 parliamentary elections. The unique set of district electoral data compiled for the three Slovak parliamentary contests represents one of the main contributions of this dissertation. The data provide important empirical evidence that informs the study of electoral geography in general and adds an additional case study to the literature on party formation and voter preferences in the post-transitional countries of Central Europe, and specifically sheds light on the transition to multiparty democracy in the Slovak Republic itself.

The literature on the transition to democratic, multi-party systems asserts that selection of the electoral system and modification of electoral rules play a significant role in party formation in the post-communist countries. This was definitely evident in the case of Slovakia; in that country, implementation of the proportional representation electoral system allowed multi-party representation and a rapid proliferation of political parties on all sides of the political spectrum in post-communist Slovakia. To sum up, there were total of 18 political parties that participated in the 1994 election, 17 in the 1998 contest, and 26 in the 2002 election. While Slovakia achieved relative stability in terms of its party system in the first ten years of democratic transition, it also witnessed the establishment of many diverse, ideologically diffused political parties with loose organization and with very broad programs. In each of the three Slovak elections there were many such political parties that did not meet the required 5 percent electoral threshold to receive seats in the parliament: 11 out of 18 in the 1994 contest, 11 out of 17 
in the 1998 contest, and 18 out of 26 in 2002 failed to clear the bar. Moreover, many of these parties received voters' support below 2 percent: 8 in 1994, 10 in 1998, and 15 in 2002 (Statistical Office of the Slovak Republic 1994, 1998, 2002). Without established voter loyalty such parties either quickly disappeared from the Slovak political scene shortly after each election or shifted their allegiance to parties that stood a better chance of actually receiving parliamentary seats via proportional representation in the consequent elections.

In comparison with the period before the division of Czechoslovakia, there were several electoral parties which established themselves after the fall of communism and whose position remains unchanged even today. Since their formation, they continue to play an essential role in the political process and elections in Slovakia. They are the Christian Democratic Movement $(K D H)$, the Movement for a Democratic Slovakia $(H Z D S)$, the Slovak National Party $(S N S)$, the Party of Hungarian Coalition (SMK-MKP), the Party of the Democratic Left $\left(S D L^{\prime}\right)$ and the Slovak Democratic Coalition $(S D K)$. This demonstrates that, despite the continued presence of the fringe parties mentioned above, after ten years of democratic transition Slovakia's party system has stabilized over time.

In addition, there were two modifications of electoral law that had profound implications on party development in post-communist Slovakia. The first change was the amendment in the system of constituencies when the country's four single electoral constituencies were combined into one. As the literature indicates, this modification, which is an example of the effect of district magnitude, mainly affected small political parties and those parties that lacked strong leadership since it diminished the link between voters and party candidates. The second change in the Slovak electoral rules was 
a modification of the electoral threshold to 5 percent for each individual party or coalition. As a result of this modification in the electoral law many small political parties merged or ceased to exist and overall this amendment contributed to the consolidation of some political parties in Slovakia, albeit still allowing for the formation of new parties as evidenced by the increase in the number of parties between the 1998 and 2002 contests. These modifications in the electoral law also influenced the regional distribution in voter support since the regional vote for political parties that were not able to secure the required 5 percent of votes to obtain seats in the parliament in one election shifted to another party or movement in the consequent election. For example, as Table 1 indicates, the Democratic Union had relatively strong support in the 1994 election, however after modification in the electoral threshold the party decided to join the Slovak Democratic Coalition to ensure that it would receive representation in the parliament in the following electoral contest. Thus, the party's regional support was reallocated to the Slovak Democratic Coalition.

Both changes in electoral rules were initiated by the populist $H Z D S$, a large political party with a strong leadership, with the goal of eliminating potential competition in the parliamentary elections. Thus, such political manipulation resulted in pre-election strategic coordination especially among pro-reform political parties. Consequently, both amendments in electoral rules had significant implications for Slovak electoral politics and party formation during the country's ten years of democratic transformation.

In regards to party formation, the scholarly literature indicates the important role that political parties play in the transition process and highlights different aspects specific to party formation in the post-communist states. Such features of party formation include 
the emergence of new political parties that led countries to the democratic transition and then disappeared within a few years after the transition. This directly applies to the case of Slovakia, where the Public Against Violence party spearheaded the country's democratic transformation right after Velvet Revolution, dominated the country's political scene without any major competition in the first years of the transition, and then dropped from the political scene a few years later. Another aspect of the post-communist party formation that is relevant to this study is the role of historical political parties in the political process; since there were few active political parties in Slovakia during the interwar period, the country's 1968 reforms had an in impact on the formation of political parties and interests groups. Additionally, according to the transitional literature on voter turnout dynamics, voters' participation in the first post-transitional election tends to be the highest, whereas the voter turnout in each consequent election is likely to decline (Kostadinova 2003, 754-755).

To properly understand voter turnout in the Slovak Republic it is important to evaluate voters' participation in the parliamentary elections starting from the first postcommunist elections, when Slovakia was still part of Czechoslovakia. The analysis of voter turnout indicates that voter participation while Slovakia was part of Czechoslovakia was $95.4 \%$ in the 1990 election and $84.2 \%$ in the 1992 electoral contest. After Slovakia became an independent country, voter turnout was $75.7 \%$ in the 1994 parliamentary election, $84.2 \%$ in the 1998 electoral contest, $70.1 \%$ in the 2002 election, and $54.7 \%$ in the 2006 contest (Statistical Office of the Slovak Republic 1994, 1998, 2002, 2006). The voter turnout data clearly indicate that participation in the 1990 parliamentary election was the highest, as we would expect, and then turnout decreased with each following 
parliamentary election except the one held in 1998 (in that case, as we noted above, frustration with the previous government of the populist Mečiar created intense civic mobilization, which made a difference in the 1998 turnout. While there was a $25 \%$ decline in voter participation in the 2002 election in comparison to the 1990 parliamentary contest, the 2002 voter turnout demonstrated that the Slovak people still recognized the importance of the electoral process and their role in affecting political outcomes, especially right before a decision was made regarding EU enlargement. This supports arguments made by the transitional literature that while the first post-communist election shows the highest voters' participation, the voter turnout decreases in all subsequent elections.

There were two main purposes set for this study. The first main purpose of this dissertation was to describe regional variations in party support and then analyze those patterns by relating them to socio-economic characteristics of the population in the districts of Slovakia to further our understanding of the correlates of voting in this postcommunist state. A secondary purpose was to relate these spatial variations to the evolution of political parties in the post-independence period in light of the literature on transitional electoral systems.

As a result of a comprehensive analysis this dissertation answers three main research questions that were posed at the beginning of the study: 
Question 1: What is the electoral geography of Slovakia and how has it changed during the decade of the country's democratic transition?

The hypothesis related to the first question was that there is a tendency among voters in certain districts to provide continuous support to the same political parties/movements over time. As the scholarly literature indicates, there are distinctive regional patterns of voting behavior found in the post-communist states of Central Europe and the states of the former Soviet Union. Further, these patterns, such as the "Red Belt" in post-Soviet Russia (wherein voters overwhelmingly and consistently favored the Communist Party of the Russian Federation) or the tendency in that same country for the urbanized regions of the Northwest, Urals and Moscow regions to support pro-reform parties and candidates, are persistent. By taking into consideration voters' party preference, scholars assert that there is a continuous regional support for the same political parties across time and that these regional bases provide parties with their principal constituencies. In summary of this point, the post-transitional literature highlights the emergence and persistence of regional power bases for various political parties. Thus, a country's regions and districts can be linked to support for a particular political party over time. Additionally, scholarly work asserts that socio-economic characteristics of populations living in different regions tend to influence voting preferences in the electoral contests.

This dissertation utilizes the cleavage model, based mainly on socio-economic characteristics of the Slovak population. Analysis of the three Slovak parliamentary elections reveals that the spatial patterns in partisan voting behavior found in other postcommunist states are also valid for the case of Slovakia. By comparing voting results 
from the 1994, 1998, and 2002 Slovak electoral contests in the 79 Slovak districts, this dissertation reaffirms that there is a continuous regional variation in voter support over time, and, furthermore, that there are established regional power bases for the pro-reform, ethnic (i.e., Hungarian) and populist/leftist parties. Furthermore, while the Slovak vote varies across different regions and districts, regionally, support for political parties remains the same across time. By employing socio-economic variables of Slovak voters and linking them to electoral vote (see below), this dissertation confirms that the population composition and the cleavages within it in the Slovak districts shape political behavior in the country. Yet, based on my results, the influence of place-specific or even idiosyncratic factors cannot be discounted, and indeed suggest that forcing a distinction between the cleavage and the place approaches is not warranted; for example, if the mayor of Slovakia's second largest city launches a new political party and garners the lion's share of votes in his home district, it is difficult to explain this by reference only to the cleavage model. The complexity of the interconnectedness of demographic or socioeconomic traits of a population on which the cleavage model is based and the real-world events or personalities or local political cultures that are external to the empirical facts challenges even the most mature scholars, as illustrated by John Agnew's classic work on Italy.

Question 2: How do the socio-economic characteristics of the Slovak population in different regions influence voting preferences in the parliamentary elections?

The hypothesis linked to this question was that the socio-economic characteristics of the Slovak population (gender, age, education, nationality, employment, income, type 
of household) in different regions tend to influence voting preferences in the parliamentary elections.

As detailed in previous chapters, the literature on voting behavior and factors that influence voter choices in the post-communist countries, studies drawn both from aggregate and individual level data, suggests that there is a correlation between sociodemographic variables and voting preferences in the post-communist countries. Various scholarly works indicate that post-transitional voting is shaped by socio-economic variables such as education, income, unemployment, age, urban/rural residence, and ethnicity. Furthermore, the literature demonstrates that urban, younger, well-educated voters are more likely to vote for pro-reform parties, whereas rural, less-educated, elderly voters tend to vote for the parties on the left or for populist parties.

The statistical correlations between and among Slovak socio-economic data and election results in this dissertation confirm what the transitional literature suggests - that with one important exception (older age), voters' electoral choices in Slovakia are indeed shaped by socio-demographic variables, especially education, nationality, unemployment, and urban/rural residence. My analysis of the Slovak data set compiled for this dissertation demonstrates that well-educated, young, urban voters living in areas with low unemployment rates tend to vote for pro-reform political parties, while less educated, rural voters, living in the areas with high unemployment rates support parties on the left of the political spectrum. A stepwise regression analysis, which sorts out the relative influence of variables within a data set, revealed that levels of unemployment and higher education and the presence of relatively more young people relates most strongly to a higher vote share for the pro-reform parties, whereas higher unemployment, a greater 
proportion of men, and a larger rural population were important in the performance of the populist $H Z D S$. In addition, Hungarian nationality exerts a powerful influence on voting behavior in Slovakia as well, where Hungarian voters who live in the southern districts located along with Slovak-Hungarian border are strongly supportive of political parties that explicitly advocate for ethnic Hungarian interests. The only discordant note in this analysis is the failure to confirm the almost universal association between older voters and leftist or populist parties that cater to them. As suggested above, this may be due to insufficient variation in the older population variable across the 79 regions. Finally, as we have seen, these results are in keeping with cross-tabulations drawn from surveys, lending additional credence to the findings derived from the aggregate data employed here.

Question \# 3: In terms of European Union enlargement, is there a correlation between voters' preferences of political parties and the way the public perceives political parties in government either as advocates of European Union membership or in contrasting stance?

The hypothesis related to this question suggests that according to survey studies there is an evident correlation between party preference and a party's position on integration into European Union, as measured by perceived attitudes regarding the benefits of EU membership.

The scholarly literature asserts that EU membership had a strong effect on emerging party systems in the post-communist countries and that party support shapes preferences related to EU integration (Vachudova 2008, 2, 861; Cichowski 2000, 1244). 
The 2002 survey data on Slovakia's integration to the European Union indicate that older and less educated voters, unqualified workers, voters living in smaller communities of 210 or 50-100 thousand people, who are supporters of leftist political parties tend not to be in favor of Slovakia becoming part of EU. In comparison, these same surveys indicate that younger and more educated voters, Hungarian nationals, residents living in large communities with over 100 thousand people, and who support pro-reform political parties tend to favor EU integration. After linking available survey and referendum data with compiled aggregate electoral data for three Slovak parliamentary elections in 79 electoral districts, it is evident that the EU membership vote is the exact reflection of the regional party vote, and that there is a strong relationship between party preference and a party's position on integration into European Union, as measured by perceived attitudes regarding the benefits of EU membership. Therefore, EU integration had a profound impact on party politics of Slovakia.

Viewed at this writing from a distance of some 20 years, the speed and scope of the profound events that reshaped the politics and, in the case of Slovakia, the map of Central and Eastern Europe and the former Soviet Union are truly amazing. Slovakia's transition to democracy and a market economy, and accession to NATO and the EU, are part of one of the most far-reaching geopolitical shifts of modern times, and our understanding of these events and processes both in that country and in the region writ large, now with the benefit of hindsight, are a challenge to scholars to make sense of. Hopefully, researchers with an interest in the politics and electoral geography of postcommunist countries will find that this dissertation makes a valuable contribution to the body of scholarship on these subjects. Likewise, it is to be hoped that those seeking to 
understand the political dynamics of post-communist Slovakia will likewise find these results useful, adding to the excellent work done by Slovak scholars such as Vladimír Krivý and others. 


\section{LIST OF REFERENCES}

Agnew, John A. 1987. Place and politics: the geographical mediation of state and society. London, England: Allen and Unwin.

Agnew, John A. 1990. Place and politics: the geographical mediation of state and society. Boston, MA: Allen and Unwin.

Agnew, John A. 1996. Mapping politics: how context counts in electoral geography. Political Geography 15 (2): 129-146.

Agnew, John A. 2002. Place and politics in modern Italy. Chicago, IL: The University of Chicago Press.

Amann, Ronald. 1990. Soviet politics in the Gorbachev era: the end of hesitant modernization. British Journal of Political Science 20 (3): 289-310.

Archer, J. Clark and Fred M. Shelly. 1985. "Theory and methodology in political geography." In Progress in political geography, ed. Michael Pacione, 11-28. London, England: Croom Helm.

Bankowicz, Marek. 1994. "Czechoslovakia: from Masaryk to Havel." In The new democracies in Eastern Europe: party systems and political cleavages, ed. Sten Berglund and Jan A. Dellebrant, 142-168. Cambridge, MA: Cambridge University Press.

Belluci, Paolo. 2008. The parliamentary election in Italy, April 2006. Electoral Studies 27 (1): 151-190.

Bielasiak, Jack. 2002. Determinants of public opinion differences on EU accession in Poland. Europe-Asia Studies 54 (8): 1241-1266.

Bielasiak, Jack and David Blunck. 2002. Post and present in transitional voting: electoral choices in post-communist Poland. Party Politics 8(5): 563-585.

Bivand, Roger. 1994. Political topographies of Central Europe: an application of spatial data analysis methods. Geografi i Bergen 199.

Bozóki, András and John T. Ishiyama, eds. 2002. The communist successor parties of Central and Eastern Europe. Armonk, NY: M.E. Sharpe.

Breslauer, George W. 2002. Gorbachev and Yeltsin as leaders. New York, NY: Cambridge University Press.

Brestovanská, Ivica. 2002. Prehl'ad územných zmien, zmien názvov obcí a názvov častí obcí vykonanných vobdobí od 1. júla 1993 do 31. decembra 2002. 
Brown, Archie. 2001. "Transformational leaders compared: Mikhail Gorbachev and Boris Yeltsin." In Gorbachev, Yeltsin, and Putin: political leadership in Russia's transition, ed. Archie Brown and Lilia Shevtsova, 11-43. Washington, D.C.: Carnegie Endowment for International Peace.

Bútora, Martin, Grigorij Mesežnikov, Zora Bútorová, and Sharon Fisher. 1999. The 1998 parliamentary elections and democratic rebirth in Slovakia. Bratislava, Slovakia: Institute for Public Affairs.

Bútora, Martin and Zora Bútorová. 1999. Slovakia's Democratic Awakening. Journal of Democracy 10 (1): 80-95.

Cameron, David R. 2003. The challenges of accession. East European Politics and Societies 17 (1): 24-41.

Cibulka, Lubor I. 1998. Elections: election system and 1998 parliamentary elections. EuroForum 1 (2). http://www.internet.sk/mediakurier/euroforum/0298/e31.htm (accessed May 16, 2009).

Cichowski, Rachel A. 2000. Western dreams, eastern realities: support for the European Union in Central and Eastern Europe. Comparative Political Studies

33 (10): 1243-1278.

Clark, Terry and Zirvinas Martinaitis. 2008. Electoral law in Central Eastern Europe: the anomalous case of Lithuania. Paper presented at the Elections, Public Opinion and Parties Annual Conference, September 12-14, in Manchester, England. http:/www.epop08.com/papers/documents/LithuaniaElectionLawsVersion30EPOP2008. doc (accessed May 16, 2009).

Clem, Ralph S. and Peter R. Craumer. 1993. The geography of the April 25 (1993) Russian referendum. Post-Soviet Geography 34 (8): 481-496.

Clem, Ralph S. and Peter R. Craumer. 1995. The politics of Russia's regions: a geographical analysis of the Russian election and constitutional plebiscite of December 1993. Post-Soviet Geography 36 (2): 67-86.

Clem, Ralph S. and Peter R. Craumer. 1995b. The geography of the Russian 1995 parliamentary election: continuity, change, and correlates. Post-Soviet Geography 36 (10): 587-616.

Clem, Ralph S. and Peter R. Craumer. 1996. Roadmap to victory: Boris Yeltsin and the Russian presidential elections of 1996. Post-Soviet Geography and Economics 37 (6): 335-354. 
Clem, Ralph S. and Peter R. Craumer. 1997. Urban-rural voting differences in Russian elections, 1995-1996: a rayon-level analysis. Post-Soviet Geography and Economics 38 (7): 379-395.

Clem, Ralph S. and Peter R. Craumer. 2000. Spatial patterns of political choice in the post-Yeltsin era: the electoral geography of Russia's 2000 presidential election. PostSoviet Geography and Economics 41 (7): 465-482.

Clem, Ralph S. and Peter R. Craumer. 2000a. Regional pattern of political preference in Russia: the December 1999 Duma elections. Post-Soviet Geography and Economics 41 (1): $1-29$.

Clem, Ralph S. and Peter R. Craumer. 2002. Urban and rural effects and party preference in Russia: new evidence from the recent Duma election. Post-Soviet Geography and Economics 43 (1): 1-12.

Clem, Ralph S. and Peter R. Craumer. 2004. Redrawing the political map of Russia: the Duma election of December 2003. Eurasian Geography and Economics 45 (4): 241-261.

Clem, Ralph S. and Marek J. Chodakiewics. 2004. Poland divided: spatial differences in the June 2003 EU accession referendum. Eurasian Geography and Economics 45 (7): 475-490.

Clem, Ralph. 2006. Russia's electoral geography: a review. Eurasian Geography and Economics 47 (4): 381-406.

Colton, Timothy. 2000. Transitional citizens: voters and what influences them in the new Russia. Cambridge, MA: Harvard University Press.

European Commission. July 1997. Agenda 2000: Opinion on Slovakia's application for membership in the European Union, DOC/97/20. Brussels. http://ec.europa.eu/enlargement/archives/pdf/dwn/opinions/slovakia/sk-op en.pdf (accessed May 16, 2009).

Cox, Gary W. 1997. Making votes count: strategic coordination in the world's electoral systems. Cambridge, England: Cambridge University Press.

Cox, Robert H. and Erich G. Frankland. 1995. The federal state and the breakup of Czechoslovakia: an institutional analysis. The Journal of Federalism 25 (1): 71-88.

Cox, K. R. 1969. The voting decision in spatial context. Progress in Geography (1) 1: $81-117$. 
Craumer, Peter R. and James I. Clem. 1999. Ukraine's emerging electoral geography: a regional analysis of the 1998 parliamentary elections. Post-Soviet Geography and Economics 40 (1): 1-26.

Dawisha, Karen. 1990. Eastern Europe, Gorbachev, and reform: the great challenge. New York, NY: Cambridge University Press.

Dawisha, Karen and Bruce Parrott, eds. 1997. The consolidation of democracy in EastCentral Europe. Cambridge, MA: Cambridge University Press.

Deegan Krausse, Kevin. 2000. Public opinion and party choice in Slovakia and the Czech Republic. Party Politics 6 (1): 23-46.

Dewatripont, Mathias and Gérard Ronald. 1995. The design of reform packages under Uncertainty. American Economic Review 85 (5): 1207-1223.

Doyle, Orla and Jan Fidrmuc. February 2003. Evolution of voting intentions during postcommunist transition: Czech Republic 1990-98. Paper presented at the European Public Choice Society meeting in Belgirate. http://www.fidrmuc.net/research/anatomy.pdf (accessed November 13, 2009).

Doyle, Orla and Patrick P. Walsh. 2005. Did political constraints bind during transition? Evidence from Czech Elections 1990-2002. Paper presented at the CEPR Annual Transition Economics Summer Workshop for Young Academics in Slovenia. http://www.tcd.ie/Economics/TEP/2005 papers/TEP15.pdf (accessed November 13, 2009).

Dowling, Maria. 2002. Czechoslovakia. New York, NY: Oxford University Press.

Duverger, Maurice. 1955. Political parties: their organization and activity in the modern state. Trans. Barbara North and Robert North. London, England: Methuen \& Co.

Duverger, Maurice. 1963. Political parties: their organization and activity in the modern state. New York, NY: Jon Wiley \& Sons.

East, Roger and Jolyon Pontin. 1997. Revolution and change in Central and Eastern Europe. London, England: Pinter Publishers.

Ekiert, Grzegorz and Jan Zielonka. 2003. Introduction: academic boundaries and path dependencies facing the EU's eastward enlargement. East European Politics and Societies 17 (1): 7-17.

Evans, Geoffrey and Stephen Whitefield. 1998. The structuring of political cleavages in post-communist societies: the case of the Czech Republic and Slovakia. Political Studies XLVI: 115-139. 
Farrell, David M. 1997. Comparing electoral systems. New York, NY: Prentice Hall. Farrell, David M. 2001. Electoral systems: a comparative introduction. New York, NY: Palgrave.

Fidrmuc, Jan. 2000. Economics of Voting in Post-Communist Countries. Electoral Studies 19 (2-3): 199-217.

FOCUS Center for Social and Market Analysis. 1998. Public opinion poll-demographic structure of the voters voting in the 1998 Slovak parliamentary elections. Bratislava, Slovakia: FOCUS.

Gorbachev, Mikhail. 1987. Perestroika: new thinking for our country and the world. New York, NY: Harper \& Row Publishers.

Gower, Jackie. 1999. "EU policy to Central and Eastern Europe." In Back to Europe: Central and Eastern Europe and the European Union, ed. Karen Henderson, 3-19. London, England: UCL Press.

Gökay, Bülent. 2001. Eastern Europe since 1970. Harlow, England: Pearson Education.

Grabbe, Heather. 2003. "Challenges of EU enlargement." In Ambivalent neighbors: the EU, NATO, and the price of membership, ed. Anatol Lieven and Dmitri Trenin, 67-89. Washington, D.C.: Carnegie Endowment for International Peace.

Grzymala-Busse, Anna M. 2002. The programmatic turnaround of communist successor parties in East Central Europe, 1989-1998. Communist and Post-Communist Studies 35 (1): 51-66.

Grzymala-Busse, Anna M. 2002a. Redeeming the Communist past: the regeneration of Communist parties in East Central Europe. New York, NY: Cambridge University Press.

Gyarfášová, Ol'ga, Vladimír Krivý, and Marian Velšic et al. 2001. Krajina v pohybe: správa a politických názoroch a hodnotách l’udí na Slovensku. Bratislava, Slovakia: Inštitút pre Verejné Otázky.

Hamžík, Pavol. 1998. "Slovakia and the European Union." In Europe beyond 2000: the enlargement of the European Union towards the East, ed. Sir William Nicoll and Richard Schoenberg, 213-220. London, England: Whurr Publishers.

Harper, Marcus A.G. 2000. Economic voting in postcommunist Eastern Europe. Comparative Political Studies 33 (9): 1191-1227.

Henderson, Karen. 2002. Slovakia: the escape from invisibility. New York, NY: Routledge. 
Hopkin, Jonathan. 2004. New Parties in Government in Italy: Comparing Lega Nord and Forza Italia. Paper presented at the European Consortium for Political Research Joint Sessions, April 13-18, in Uppsala, Sweden.

Huntington, Samuel P. Summer 1984. Will more countries become democratic? Political Science Quarterly 99: 217.

IFES Election Guide - country profile: Czech Republic. http://www.electionguide.org/election.php?ID=1674 (accessed May 16, 2008).

IFES Election Guide - country profile: Hungary. http://www.electionguide.org/country.php?ID=99 (accessed May 16, 2008).

IFES Election Guide - country profile: Poland. http://www.electionguide.org/country.php?ID=173 (accessed May 16, 2008).

IFES Election Guide - country profile: Russia. http://www.electionguide.org/country.php?ID=179 (accessed May 16, 2008).

IFES Election Guide - country profile: Slovakia. http://www.electionguide.org/country.php?ID=194 (accessed May 16, 2008).

Inter-Parliamentary Union (IPU). Parline database on national parliaments: Czech Republic - Chamber of Deputies and Senate. http://www.ipu.org/parline-e/reports/2083 B.htm (accessed May 16, 2008). http://www.ipu.org/parline-e/reports/2084_B.htm (accessed May 16, 2008).

Inter-Parliamentary Union (IPU). Parline database on national parliaments: Hungary National Assembly. http://www.ipu.org/parline-e/reports/2141_B.htm (accessed May 16, 2008).

Inter-Parliamentary Union (IPU). Parline database on national parliaments: Poland Sejm and Senate.

http://www.ipu.org/parline-e/reports/2255 B.htm (accessed May 16, 2008). http://www.ipu.org/parline-e/reports/2256 B.htm (accessed May 16, 2008).

Inter-Parliamentary Union (IPU). Parline database on national parliaments: Russian Federation - Council of the Federation and State Duma. http://www.ipu.org/parline/reports/2263 B.htm (accessed May 16, 2008). http://www.ipu.org/parline-e/reports/2264_B.htm (accessed May 16, 2008).

Inter-Parliamentary Union (IPU). Parline database on national parliaments: Slovakia National Council. http://www.ipu.org/parline-e/reports/2285 B.htm (accessed May 16, 2008). 
Jasiewicz, Krzysztof. 1998. "Elections and voting behavior." In Developments in Central and Eastern European politics, ed. S. White, J. Batt, and P.G. Lewis, 166-187. Durham, NC: Duke University Press.

Johannsen, Lars. 2003. The foundations of the state: emerging urban-rural cleavages in transitions countries. Communist and Post-Communist Studies 36: 291-309.

Katedra sociálno-politologických vied Filozofickej fakulty Prešovskej univerzity v Prešove. 1998. Volby 1998 v Slovenskej Republike. Prešov, Slovakia: Prešovská Univerzita.

Kitschelt, Herbert, Zdenka Mansfeldova, Radoslav Markowski, and Gabor Toka. 1999. Post-communist party systems: competition, representation, and inter-party cooperation. Cambridge, England: Cambridge University Press.

Korba, Matúšs. 2003. "Foreign policy.” In Slovak elections 2002: results, implications, context, ed. Grigorij Mesežnikov, Ol'ga Gyárfášová, Miroslav Kollár, and Tom Nicholson, 233-243. Bratislava, Slovakia: The Institute of Public Affairs.

Kostadinova. Tatiana. 2003. Voter turnout dynamics in post-communist Europe. European Journal of Political Research 42: 741-759.

Kostadinova, Tatiana. 2006. Party strategies and voter behavior in the East European mixed election systems. Party Politics 12 (1): 121-143.

Kostadinova, Tatiana and Timothy J. Power. September 2007. Does democratization depress participation? Voter turnout in the Latin American and Eastern European transitional democracies. Political Research Quarterly 60(3): 363-377.

Kovács, András. Summer 1996. Did the losers really win? An analysis of electoral behavior in Hungary in 1994. Social Research 63: 511-530.

Kovács, Zoltan and Alan Dingsdale. 1998. Whither East European democracies? The geography of the 1994 Hungarian parliamentary election. Political Geography 17 (4): 437-458.

Krivý, Vladimír. August 1998. Hodnotové orientácie na Slovensku - skupinové portréty. Bratislava, Slovakia: Inštitút pre Verejné Otázky.

Krivý, Vladimír. 1999. Čo prezrádzajú volebné výsledky? Parlamentné vol'by 1992-1998. Bratislava, Slovakia: Inštitút pre Verejné Otázky.

Krivý, Vladimír. 1999a. "Volebné výsledky.” In Slovenské vol'by '98: Kto? Prečo? Ako?, ed. Martin Bútora, Grigorij Mesežnikov, Zora Bútorová, 245-260. Bratislava, Slovakia: Inštitút pre Verejné Otázky. 
Krivý, Vladimír. June 2000. Politické orientácie na Slovensku - skupinové profily. Bratislava, Slovakia: Inštitút pre Verejné Otázky.

Lijphart, Arend. 1994. Electoral systems and party systems - a study of twenty-seven democracies: 1945-1990. Oxford, England: Oxford University Press.

Lipset, Seymor M. and Stein Rokkan, eds. 1967. Party systems and voter alignments: cross-national perspectives. New York, NY: Free Press.

Mainwaring, Scott. 1999. Rethinking party systems in the third way of democratization: the case of Brazil. Stanford, CA: Stanford University Press.

Marsch. Christopher. 2002. Russia at the polls: voters, elections, and democratization. Washington, D.C.: A Division of Congressional Quarterly Inc.

Mason, David S. 1996. Revolution and transition in East-Central Europe. Boulder, CO: Westview Press.

Matějů, Petr and Klára Vlachová. 1998. Values and electoral decisions in the Czech Republic. Communist and Post-Communist Studies 31 (3): 249-269.

McFaul, Michael. 2001. Explaining party formation and nonformation in Russia. Comparative Political Studies (34) 10: 1159-1187.

Mesežnikov, Grigorij. 1999. "Vol'by 1998 a vývoj systému politických strán." In Slovenské Vol'by ' 98: Kto? Prečo? Ako?, ed. Martin Bútora, Grigorij Mesežnikov, and Zora Bútorová, 37-49. Bratislava, Slovakia: Inštitút pre Verejné Otázky.

Mesežnikov, Grigorij, Ol'ga Gyarfášová, Miroslav Kollár, and Tom Nicholson, eds. 2002. Slovak elections 2002: results, implications, context. Bratislava, Slovakia: Institute for Public Affairs.

Millard, F. 2003. Elections in Poland 2001: electoral manipulation and party upheaval. Communist and Post-Communist Studies 36 (1): 69-86.

Moser, Robert G. 1999. Electoral systems and the number of parties in postcommunist states. World Politics 51 (3): 359-384.

Moser, Robert. 2001. Unexpected outcomes: electoral systems, political parties, and representation in Russia. Pittsburgh, PA: University of Pittsburgh Press.

Murphy, Alexander. 1990. "Electoral geography and the ideology of place: the making of regions in Belgian electoral politics." In Developments in electoral geography, ed. R.J. Johnston, F.M. Shelley, and P.J. Taylor, 227-241. New York, NY: Routledge. 
Newton, Brian and Linda Walsh. 1999. "The Slovak Republic: on the edge of Europe.” In Pushing back the boundaries: the European Union and Central and Eastern Europe, ed. Mike Mannin, 250-275. Manchester, England: Manchester University Press.

Nohlen, Dieter, ed. 1993. Enciclopedia electoral Latinoamericana y del Caribe. San Jose: Instituto Interamricano de Derechos Humanos.

O'Loughlin, John and A.J. Parker. 1990. "Tradition contra change: the political geography of Irish referenda, 1937-87." In Developments in electoral geography, ed. R.J. Johnston, F.M. Shelley, and P.J. Taylor, 60-85. New York, NY: Routledge.

O'Loughlin, John, Colin Flint, and Luc Anselin. September 1994. The geography of the Nazi vote: context, confession and class in the Reichstag election of 1930. Annals of the Association of American Geographers 84 (3): 351-380.

Parrott, Bruce. 1997. "Perspectives on postcommunist democratization." In The consolidation of democracy in East-Central Europe, ed. Karen Dawisha and Bruce Parrott, 1-39. Cambridge, England: Cambridge University Press.

Pithart, Petr and Metta Spencer. 1998. "The partition of Czechoslovakia." In Separatism: democracy and disintegration, Metta Spencer, 185-204. Lanham, MD: Rowman and Littlefield.

Plecitá - Vlachová, Klára and Mary Stegmaier. 2008. The parliamentary election in the Czech Republic, June 2006. Electoral Studies 27 (1): 179-184.

Pridham, Geoffrey. 2002. The European Union's democratic conditionality and domestic politics in Slovakia: the Mečiar and Dzurinda governments compared. Europe-Asia Studies 54 (2): 203-227.

Rae, Douglas W. 1967. The political consequences of electoral laws. New Haven, CT: Yale University Press.

Reynolds, David. 1990. "Whither electoral geography? A critique." In Developments in electoral geography, ed. R.J. Johnston, F.M. Shelley, and P.J. Taylor, 22-38. New York, NY: Routledge.

Roper, Steven and Florin Fesnic. 2003. Historical legacies and their impact on postcommunist voting behaviour. Europe-Asia Studies 55 (1): 119-131.

Rupnik, Jacques. 2000. Eastern Europe: the international context. Journal of Democracy 11 (2): 115-129.

Rybár, Marek and Kevin Deegan-Krause. 2008. Slovakia’s Communist successor parties in comparative perspective. Communist and Post-Communist Studies 41: 497-519. 
Sakwa, Richard. 1991. Gorbachev and his reforms: 1985-1990. New York, NY: Prentice Hall.

Shabad, Goldie and Kazimierz M. Slomczynski. 1999. Political identities in the initial phase of systemic transformation in Poland: a test of the tabula rasa hypothesis. Comparative Political Studies 32 (6): 690-723.

Shaw, Denis J.B. 1999: Russia in the modern world: a new geography. Oxford, England: Blackwell Publishers.

Shelly, Fred. M., R. J. Johnston, and Peter J. Taylor. 1990. "Developments in electoral geography." In Developments in electoral geography, ed. R.J. Johnston, F.M. Shelley, and P.J. Taylor, 1-14. New York, NY: Routledge.

Shepherd, Robin H.E. 2000. Czechoslovakia: the velvet revolution and beyond. New York, NY: St. Martin's Press.

Shvetsova, Olga. 1999. A survey of post-communist electoral institutions: 1990-1998. Electoral Studies 18 (3): 397-409.

Sigma - Support for Improvement in Governance and Management in Central and Eastern European Countries. 1995. Public management profiles. Slovakia: legislative authority, January 1. http://interdev.oecd.org/puma/sigmaweb/profiles/slovakia/svk3.htm (accessed February 27, 2001).

Slovakia Document Store. 1994. Official results of Slovak 1994 parliamentary election by region. http://slovakia.eunet.sk/slovakia/elections-94/resreg.gif (accessed May 16, 2008).

Sme.sk. 2002. Vitazné politické strany podla okresov Slovenskej Republiky. http://volby.sme.sk/c/674423/vitazne-politicke-strany-podla-okresov-slovenskejrepubliky.html (accessed May 16, 2008).

Snyder, Jack. 1987-1988. The Gorbachev revolution: a waning of Soviet expansionism? International Security 12 (3): 93-131.

Statistical Office of the Slovak Republic. 1994 parliamentary election - percentage of valid votes for political parties or political movements. http://portal.statistics.sk/volby98/1994/volby21.htm (accessed May 16, 2008).

Statistical Office of the Slovak Republic. 1994 and 1998 parliamentary elections. http://portal.statistics.sk/showdoc.do?docid=4490 (accessed May 16, 2008).

Statistical Office of the Slovak Republic. 1994, 1998, and 2002 parliamentary elections registered political parties. http://portal.statistics.sk/showdoc.do?docid=4490. 
Statistical Office of the Slovak Republic. 1994, 1998, and 2002 parliamentary elections total voting results. http://portal.statistics.sk/showdoc.do?docid=4490 (accessed May 16, 2008).

Statistical Office of the Slovak Republic. 1994, 1998, 2002, 2006 parliamentary elections. http://portal.statistics.sk/showdoc.do?docid=4490 (accessed May 16, 2008).

Statistical Office of the Slovak Republic. 1998 parliamentary election - percentage of valid votes for political parties or political movements. http://portal.statistics.sk/volby98/results/tab2.jsp (accessed May 16, 2008).

Statistical Office of the Slovak Republic. 1998 parliamentary election - percentage of valid votes for political parties by districts. http://portal.statistics.sk/volby98/eng/results/tab15_s.jsp (accessed May 16, 2008).

Statistical Office of the Slovak Republic. 2002 parliamentary election - percentage of valid votes for political parties or political movements.

http://portal.statistics.sk/volby2002/webdata/engl/tab/tab3.htm (accessed May 16, 2008).

Statistical Office of the Slovak Republic. 2002 parliamentary election - percentage of valid votes for political parties by districts.

http://portal.statistics.sk/volby2002/webdata/vysledky a.htm (accessed May 16, 2008).

Statistical Office of the Slovak Republic. 2002 parliamentary election - numbers of seats assigned to political parties.

http://portal.statistics.sk/volby2002/webdata/engl/graf/graf2.htm (accessed May 16, 2008).

Statistical Office of the Slovak Republic. 2002 parliamentary election - political parties with the highest number of valid votes in districts.

http://www.statistics.sk/volby2002/webdata/slov/graf/strokr.htm (accessed May 16, 2008).

Statistical Office of the Slovak Republic. 2003. EU integration referendum. http://portal.statistics.sk/ref_2003/webdata/en/menu a.htm (accessed May 16, 2009).

Statistical Office of the Slovak Republic. 2003a. Share of the number of participants in the referendum who answered - yes. http://portal.statistics.sk/ref_2003/webdata/en/graf/kart2_a.htm (accessed May 16, 2008). 
Statistical Office of the Slovak Republic. 2003b. Share of the number of participants in the referendum who answered - no.

http://portal.statistics.sk/ref_2003/webdata/en/graf/kart3_a.htm (accessed May 16, 2008).

Statistical Office of the Slovak Republic. Slovak regions - socio-economic characteristics of the population. 1996, 2001, 2003.

Statistical Yearbook of the Czech and Slovak Federal Republic. 1991. 1990 Parliamentary Elections: Czech and Slovak National Council. Prague, Czech Republic: SNTL.

Szczerbiak, Aleks. March 2001. Polish public opinion: explaining declining support for EU membership. Journal of Common Market Studies 39 (1): 105-122.

Škrabala, Marek. 2002. "Vstup Slovenska do NATO a Európskej Únie očami občanov." In Informatívne správy Štatistického Úradu SR, November 4, 1-21. Bratislava, Slovakia: Ústav pre Výskum Verejnej Mienky pri Štatistickom Úrade SR.

Škrabala, Marek. 2002b. "Postoje občanov k vstupu Slovenska do Európskej Únie.” In Informatívne správy Štatistického Úradu SR, October 21, 1-4. Bratislava, Slovakia: Ústav pre Výskum Verejnej Mienky pri Štatistickom Úrade SR.

Taagepera, Rein, and Matthew S. Shugart. 1989. Seats and votes: the effects and determinants of electoral systems. New Haven, CT: Yale University Press.

Tatraview.com. 2009. Slovakia's regions. www.tatraview.com/geography.html (accessed November 13, 2009).

Tucker, Joshua A. 2006. Regional economic voting: Russia, Poland, Hungary, Slovakia and the Czech Republic, 1990-1999. New York, NY: Cambridge University Press.

Vachudova, Milada A. 2008. Tempered by the EU? Political parties and party systems before and after accession. Journal of European Public Policy 15 (6): 861-879.

Vachudova, Milada A. July 2009. Postcommunist politics in a magnetic field: How transition and EU accession structure party competition on European integration. Comparative European Politics 7 (2): 179-212.

Vanlaer, Jean. 1991. Les premieres election libres en Europe de l'Est: systemes d partis et clivages regionaux. Revue Belge de Geographie 115:1-2-3.

Vlachová, Klára. 2001. Party identification in the Czech Republic: inter-party hostility and party preference. Communist and Post-Communist Studies 34: 479-499.

Vlčková, Viera. 1995. Geografické aspekty výsledkov volieb do SNR a Národnej rady SR: 1990 - 1992 - 1994. Elita. 
Von Beyme, Klaus. 1998. "Parties and party systems in Eastern Europe." In Central and Eastern Europe in transition: volume 1, ed. Frank H. Columbus, 1-19. Commack, NY: Nova Science Publishers.

Wheaton, Bernard and Zdeněk Kavan. 1992. The velvet revolution: Czechoslovakia, 1988-1991. Boulder, CO: Westview Press.

Whitefield, Stephen. 2002. Political cleavages and post-communist politics. Annual Review of Politics 5: 181-200.

Wightman, Gordon, ed. 1995. Party formation in East-Central Europe: post-communist politics in Czechoslovakia, Hungary, Poland and Bulgaria. Brookfield, VT.

Wolchik, Sharon L. 1997. "Democratization and political participation in Slovakia." In The consolidation of democracy in East-Central Europe, ed. Karen Dawisha and Bruce Parrott, 197-244. Cambridge, MA: Cambridge University Press.

Zarycki, Tomasz and Andrzej Nowak. 2000. Hidden dimensions: the stability and structure of regional political cleavages in Poland. Communist and Post-Communist Studies 33: 331-354. 
APPENDICES 
Appendix 1 - 1994 Slovak Election - Voting Results and List of Political Parties 


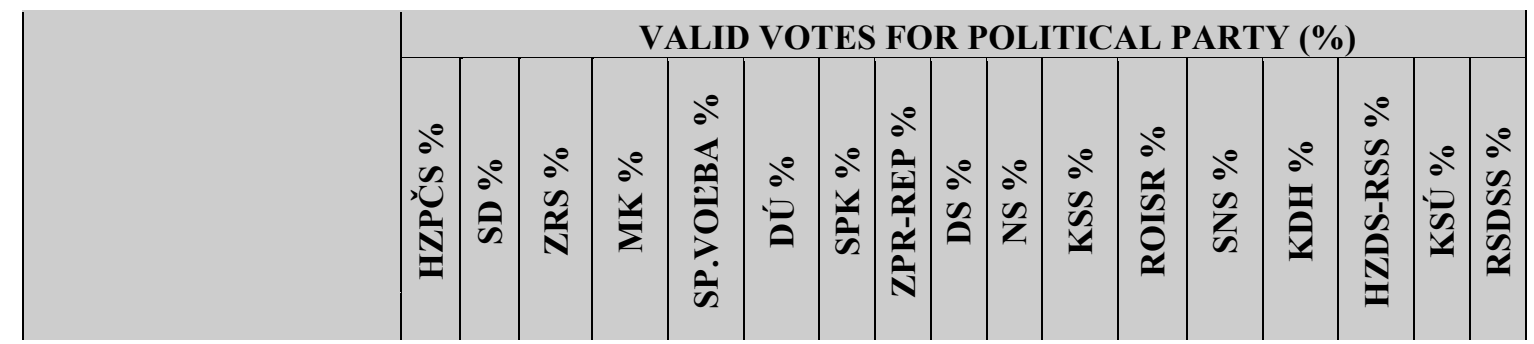

\section{Bratislavský Region}

Bratislava I

Bratislava II

Bratislava III

Bratislava IV

Bratislava V

Malacky

Pezinok

Senec

Trnavský Region

Dunajská Streda

Galanta

Hlohovec

Piešt’any

Senica

Skalica

Trnava

\section{Trenčiansky Region}

Bánovce nad Bebravou

Ilava

Myjava

Nové Mesto nad Váhom

Partizánske

Považská Bystrica

Prievidza

Púchov

Trenčín

\section{Nitriansky Region}

Komárno

Levice

Nitra

Nové Zámky

Šal'a

Topol'čany

Zlaté Moravce

Žilinský Region

Bytča

Čadca

Dolný Kubín $\begin{array}{lllllllllllllllll}0.7 & 0.1 & 2.1 & 3.1 & 12.9 & 20.5 & 0.9 & 0.0 & 7.4 & 2.1 & 1.2 & 0.2 & 7.3 & 18.1 & 21.8 & 1.5 & 0.1\end{array}$ $\begin{array}{lllllllllllllllll}0.7 & 0.2 & 3.9 & 5.5 & 13.0 & 17.7 & 1.5 & 0.0 & 5.1 & 2.2 & 1.4 & 0.1 & 8.7 & 11.5 & 27.2 & 1.3 & 0.1\end{array}$ $\begin{array}{lllllllllllllllll}0.7 & 0.1 & 4.0 & 2.3 & 12.7 & 17.3 & 1.3 & 0.0 & 5.3 & 2.2 & 1.6 & 0.1 & 9.3 & 12.3 & 29.4 & 1.2 & 0.1\end{array}$ $\begin{array}{llllllllllllllllll}0.6 & 0.1 & 4.4 & 2.0 & 14.5 & 18.6 & 1.6 & 0.0 & 6.3 & 2.5 & 1.5 & 0.1 & 9.6 & 12.3 & 24.8 & 1.1 & 0.1\end{array}$ $\begin{array}{llllllllllllllllll}0.7 & 0.2 & 4.9 & 3.2 & 15.7 & 18.6 & 2.1 & 0.0 & 5.7 & 2.5 & 1.3 & 0.1 & 10.0 & 10.5 & 23.3 & 1.1 & 0.1\end{array}$ $\begin{array}{llllllllllllllllll}1.3 & 0.3 & 7.2 & 0.2 & 11.3 & 9.7 & 2.1 & 0.0 & 4.0 & 1.1 & 3.8 & 0.5 & 6.4 & 10.8 & 38.9 & 2.2 & 0.2\end{array}$ $\begin{array}{lllllllllllllllll}0.6 & 0.1 & 4.8 & 0.2 & 9.9 & 10.1 & 1.3 & 0.0 & 4.1 & 1.8 & 1.9 & 0.1 & 9.2 & 10.5 & 43.4 & 1.9 & 0.1\end{array}$ $\begin{array}{lllllllllllllllllll}0.9 & 0.2 & 4.7 & 22.5 & 9.7 & 8.4 & 1.7 & 0.0 & 2.6 & 1.4 & 2.8 & 0.2 & 6.0 & 7.8 & 29.3 & 1.7 & 0.1\end{array}$

$\begin{array}{lllllllllllllllll}0.8 & 0.2 & 0.9 & 83.2 & 4.6 & 2.1 & 0.6 & 0.0 & 0.7 & 0.3 & 1.1 & 0.5 & 0.7 & 1.1 & 2.9 & 0.2 & 0.1\end{array}$ $\begin{array}{lllllllllllllllll}0.9 & 0.2 & 5.2 & 39.9 & 7.0 & 4.4 & 1.0 & 0.0 & 1.7 & 0.6 & 3.8 & 0.6 & 4.1 & 4.3 & 25.1 & 1.2 & 0.1\end{array}$ $\begin{array}{lllllllllllllllll}0.6 & 0.2 & 7.9 & 0.2 & 8.2 & 6.1 & 1.4 & 0.0 & 3.1 & 0.9 & 1.7 & 0.2 & 6.7 & 12.0 & 48.5 & 2.1 & 0.1\end{array}$ $\begin{array}{llllllllllllllllll}1.0 & 0.1 & 5.8 & 0.2 & 9.9 & 9.4 & 1.4 & 0.0 & 4.2 & 1.4 & 1.3 & 0.1 & 9.4 & 12.0 & 41.1 & 2.7 & 0.1\end{array}$ $\begin{array}{lllllllllllllllll}1.9 & 0.4 & 7.1 & 0.1 & 17.0 & 8.7 & 1.6 & 0.1 & 3.4 & 0.7 & 2.3 & 0.3 & 4.4 & 14.4 & 35.1 & 2.4 & 0.2\end{array}$ $\begin{array}{lllllllllllllllll}5.7 & 0.6 & 7.4 & 0.1 & 15.6 & 13.9 & 1.4 & 0.3 & 4.2 & 0.5 & 4.1 & 0.3 & 3.0 & 20.4 & 20.6 & 1.9 & 0.1\end{array}$ $\begin{array}{lllllllllllllllll}0.7 & 0.2 & 6.3 & 0.1 & 10.7 & 8.7 & 1.9 & 0.1 & 2.9 & 1.2 & 2.0 & 0.2 & 7.3 & 13.4 & 42.6 & 1.6 & 0.1\end{array}$

$\begin{array}{lllllllllllllllll}0.7 & 0.1 & 6.9 & 0.1 & 10.8 & 3.9 & 1.5 & 0.1 & 2.1 & 1.0 & 2.8 & 0.2 & 7.1 & 9.7 & 51.0 & 1.9 & 0.1\end{array}$ $\begin{array}{lllllllllllllllll}0.6 & 0.2 & 4.4 & 0.0 & 8.0 & 6.6 & 1.4 & 0.1 & 2.8 & 1.0 & 1.5 & 0.1 & 7.2 & 7.9 & 55.3 & 2.9 & 0.1\end{array}$ $\begin{array}{lllllllllllllllll}2.1 & 0.4 & 12.2 & 0.1 & 13.6 & 7.2 & 1.5 & 0.0 & 6.8 & 1.0 & 2.0 & 0.2 & 4.5 & 2.4 & 45.4 & 0.5 & 0.1\end{array}$ $\begin{array}{lllllllllllllllll}1.5 & 0.2 & 8.6 & 0.1 & 10.6 & 7.3 & 1.8 & 0.1 & 3.8 & 1.4 & 2.3 & 0.2 & 4.6 & 9.9 & 44.7 & 2.6 & 0.1\end{array}$ $\begin{array}{lllllllllllllllll}0.5 & 0.1 & 5.4 & 0.1 & 9.0 & 4.6 & 1.4 & 0.0 & 1.7 & 0.9 & 1.6 & 0.1 & 8.2 & 11.2 & 52.6 & 2.3 & 0.1\end{array}$ $\begin{array}{lllllllllllllllll}0.6 & 0.2 & 4.5 & 0.1 & 6.3 & 6.4 & 1.0 & 0.0 & 3.1 & 0.9 & 1.9 & 0.0 & 10.8 & 8.5 & 52.9 & 2.6 & 0.1\end{array}$ $\begin{array}{lllllllllllllllll}0.5 & 0.2 & 8.0 & 0.2 & 9.0 & 6.9 & 1.2 & 0.0 & 2.7 & 2.4 & 2.3 & 0.1 & 7.5 & 6.2 & 51.0 & 1.7 & 0.1\end{array}$ $\begin{array}{llllllllllllllllll}0.8 & 0.1 & 4.7 & 0.1 & 6.1 & 7.1 & 1.2 & 0.0 & 2.5 & 0.9 & 1.8 & 0.1 & 7.3 & 9.1 & 55.3 & 2.6 & 0.1\end{array}$ $\begin{array}{lllllllllllllllll}1.0 & 0.2 & 4.6 & 0.1 & 10.2 & 8.4 & 1.5 & 0.0 & 3.8 & 1.5 & 1.5 & 0.0 & 7.0 & 11.6 & 46.0 & 2.4 & 0.1\end{array}$

$\begin{array}{lllllllllllllllll}1.1 & 0.2 & 2.0 & 71.0 & 6.3 & 4.0 & 0.8 & 0.0 & 1.6 & 0.3 & 1.8 & 0.2 & 2.0 & 1.3 & 7.0 & 0.2 & 0.1\end{array}$ $\begin{array}{lllllllllllllllll}1.1 & 0.3 & 5.5 & 29.6 & 11.9 & 5.9 & 1.6 & 0.0 & 3.6 & 0.9 & 2.8 & 0.5 & 4.7 & 5.4 & 24.8 & 1.4 & 0.2\end{array}$ $\begin{array}{llllllllllllllllll}0.8 & 0.2 & 7.3 & 7.7 & 9.3 & 7.2 & 1.2 & 0.0 & 3.5 & 1.1 & 2.2 & 0.4 & 6.1 & 9.7 & 41.2 & 2.0 & 0.2\end{array}$ $\begin{array}{lllllllllllllllll}1.1 & 0.1 & 4.9 & 39.9 & 8.7 & 4.9 & 1.0 & 0.1 & 2.1 & 0.6 & 2.3 & 0.2 & 4.9 & 3.7 & 24.0 & 1.4 & 0.1\end{array}$ $\begin{array}{lllllllllllllllll}1.2 & 0.2 & 4.7 & 39.2 & 8.8 & 6.4 & 1.2 & 0.0 & 2.3 & 0.9 & 4.0 & 0.9 & 3.9 & 5.0 & 19.8 & 1.3 & 0.2\end{array}$ $\begin{array}{lllllllllllllllll}0.7 & 0.1 & 4.9 & 0.1 & 7.5 & 4.9 & 1.0 & 0.0 & 1.7 & 0.8 & 2.3 & 0.1 & 8.1 & 9.7 & 56.4 & 1.7 & 0.2\end{array}$ $\begin{array}{lllllllllllllllll}0.7 & 0.1 & 6.7 & 1.0 & 6.3 & 3.6 & 1.0 & 0.0 & 2.0 & 0.9 & 2.0 & 0.1 & 9.2 & 9.8 & 53.4 & 3.1 & 0.1\end{array}$

$\begin{array}{lllllllllllllllll}0.6 & 0.4 & 4.2 & 0.0 & 5.5 & 4.9 & 1.0 & 0.0 & 1.7 & 0.5 & 1.7 & 0.0 & 8.2 & 10.0 & 59.0 & 2.1 & 0.1\end{array}$ $\begin{array}{lllllllllllllllll}1.2 & 0.2 & 8.6 & 0.1 & 4.7 & 5.5 & 0.8 & 0.0 & 1.3 & 0.6 & 1.5 & 0.0 & 6.8 & 9.6 & 56.9 & 2.2 & 0.1\end{array}$ $\begin{array}{llllllllllllllllll}0.7 & 0.4 & 6.4 & 0.1 & 10.2 & 8.0 & 1.2 & 0.0 & 3.7 & 1.5 & 2.0 & 0.1 & 5.4 & 20.1 & 35.3 & 4.9 & 0.1\end{array}$ 


$\begin{array}{lrrrrrrrrrrrrrrrrr}\text { Kysucké Nové Mesto } & 0.6 & 0.3 & 5.6 & 0.0 & 5.4 & 3.9 & 0.7 & 0.0 & 1.4 & 0.8 & 2.1 & 0.0 & 10.2 & 7.8 & 59.7 & 1.4 & 0.1 \\ \text { Liptovský Mikuláš } & 0.7 & 0.2 & 10.1 & 0.2 & 13.9 & 8.2 & 1.4 & 0.0 & 5.3 & 1.1 & 2.7 & 0.2 & 4.7 & 5.8 & 44.0 & 1.3 & 0.1 \\ \text { Martin } & 0.8 & 0.3 & 13.1 & 0.2 & 12.5 & 11.5 & 1.7 & 0.0 & 4.6 & 2.4 & 2.4 & 0.3 & 4.9 & 6.5 & 36.9 & 1.7 & 0.1 \\ \text { Námestovo } & 0.5 & 0.3 & 5.9 & 0.0 & 4.3 & 5.8 & 0.9 & 0.0 & 1.7 & 0.8 & 1.0 & 0.0 & 7.6 & 25.8 & 38.8 & 6.5 & 0.1 \\ \text { Ružomberok } & 0.5 & 0.2 & 8.2 & 0.2 & 6.6 & 7.4 & 0.9 & 0.0 & 3.4 & 1.0 & 1.9 & 0.3 & 5.9 & 15.5 & 40.9 & 7.0 & 0.1 \\ \text { Turčianske Teplice } & 0.8 & 0.2 & 12.6 & 0.2 & 12.0 & 7.1 & 1.1 & 0.1 & 2.7 & 1.3 & 3.9 & 0.1 & 3.8 & 5.7 & 46.1 & 2.2 & 0.2 \\ \text { Tvrdošín } & 0.4 & 0.1 & 3.5 & 0.0 & 3.6 & 4.8 & 0.7 & 0.0 & 1.7 & 0.9 & 0.7 & 0.0 & 13.7 & 19.6 & 42.0 & 8.0 & 0.1 \\ \text { Žilina } & 0.5 & 0.5 & 4.6 & 0.1 & 7.2 & 9.4 & 1.0 & 0.0 & 3.7 & 1.2 & 1.5 & 0.2 & 9.1 & 10.1 & 48.6 & 2.3 & 0.0\end{array}$

\section{Banskobystrický Region}

Banská Bystrica

Banská Štiavnica

Brezno

Detva

Krupina

Lučenec

Poltár

Revúca

Rimavská Sobota

Vel'ký Krtíš

Zvolen

Žarnovica

Žiar nad Hronom

Prešovský Region

Bardejov

Humenné

Kežmarok

Levoča

Medzilaborce

Poprad

Prešov

Sabinov

Snina

Stará Lubovňa

Stropkov

Svidník

Vranov nad Topl'ou

Košický Region

Gelnica

Košice I

Košice II

Košice III

Košice IV

Košice - okolie

Michalovce

Rožňava

Sobrance $\begin{array}{lllllllllllllllll}0.8 & 0.3 & 8.9 & 0.3 & 12.2 & 14.6 & 1.4 & 0.0 & 5.8 & 2.5 & 2.6 & 0.2 & 5.8 & 7.3 & 35.3 & 1.8 & 0.1\end{array}$ $\begin{array}{llllllllllllllllll}0.6 & 0.2 & 9.4 & 0.1 & 7.4 & 6.6 & 1.5 & 0.0 & 2.9 & 1.0 & 3.8 & 0.7 & 5.5 & 8.1 & 49.4 & 2.7 & 0.1\end{array}$

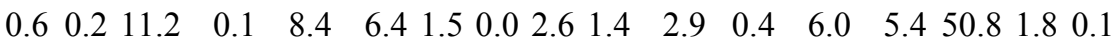
$\begin{array}{lllllllllllllllll}0.4 & 0.2 & 6.5 & 0.1 & 5.0 & 3.9 & 1.0 & 0.0 & 2.7 & 1.1 & 2.3 & 0.5 & 6.4 & 5.5 & 60.0 & 4.5 & 0.1\end{array}$ $\begin{array}{llllllllllllllllll}0.4 & 0.2 & 6.9 & 0.3 & 12.8 & 5.3 & 1.1 & 0.0 & 2.8 & 0.8 & 2.3 & 0.6 & 4.5 & 9.1 & 48.8 & 3.8 & 0.2\end{array}$ $\begin{array}{lllllllllllllllll}1.1 & 0.3 & 6.9 & 25.2 & 8.8 & 10.3 & 1.1 & 0.0 & 2.8 & 1.1 & 4.9 & 0.7 & 4.4 & 3.3 & 27.1 & 1.7 & 0.2\end{array}$

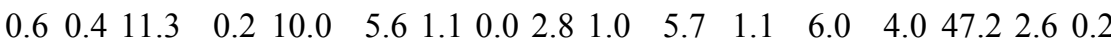

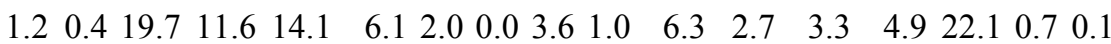
$\begin{array}{lllllllllllllllll}1.1 & 0.3 & 8.8 & 39.2 & 10.4 & 6.0 & 1.2 & 0.1 & 2.0 & 0.7 & 3.9 & 1.1 & 2.8 & 1.9 & 19.3 & 1.0 & 0.2\end{array}$ $\begin{array}{lllllllllllllllll}0.9 & 0.3 & 7.3 & 29.0 & 11.6 & 7.5 & 1.4 & 0.0 & 2.2 & 0.8 & 4.4 & 1.1 & 2.4 & 3.2 & 26.3 & 1.5 & 0.2\end{array}$ $\begin{array}{lllllllllllllllll}0.7 & 0.2 & 9.6 & 0.4 & 10.7 & 10.7 & 1.4 & 0.0 & 4.9 & 1.8 & 2.9 & 0.3 & 6.3 & 6.4 & 42.1 & 1.6 & 0.1\end{array}$ $\begin{array}{lllllllllllllllll}0.5 & 0.3 & 10.6 & 0.1 & 6.5 & 4.4 & 1.2 & 0.0 & 2.1 & 0.7 & 2.6 & 0.2 & 5.9 & 6.7 & 55.7 & 2.5 & 0.1\end{array}$ $\begin{array}{lllllllllllllllll}0.4 & 0.2 & 7.8 & 0.1 & 6.8 & 6.7 & 1.6 & 0.0 & 3.8 & 1.4 & 2.6 & 0.3 & 8.0 & 5.4 & 52.8 & 2.0 & 0.1\end{array}$

$\begin{array}{lllllllllllllllll}1.3 & 0.3 & 11.1 & 0.1 & 13.0 & 6.6 & 1.2 & 0.0 & 3.9 & 1.5 & 3.2 & 2.0 & 3.2 & 17.7 & 32.5 & 2.2 & 0.2\end{array}$ $\begin{array}{llllllllllllllllll}1.0 & 0.3 & 11.7 & 0.2 & 10.3 & 6.8 & 1.0 & 0.1 & 2.6 & 1.4 & 5.2 & 1.4 & 2.9 & 15.6 & 35.1 & 4.3 & 0.2\end{array}$ $\begin{array}{lllllllllllllllll}2.1 & 0.3 & 9.5 & 0.2 & 10.4 & 8.3 & 2.0 & 0.0 & 3.0 & 1.3 & 3.1 & 4.2 & 2.9 & 25.3 & 24.6 & 2.5 & 0.2\end{array}$ $\begin{array}{llllllllllllllllll}1.2 & 0.3 & 10.0 & 0.1 & 8.0 & 7.7 & 1.2 & 0.1 & 3.4 & 1.4 & 2.6 & 2.3 & 3.1 & 24.4 & 31.3 & 2.9 & 0.2\end{array}$ $\begin{array}{lllllllllllllllll}1.9 & 0.2 & 16.8 & 0.0 & 15.9 & 5.6 & 0.9 & 0.1 & 1.9 & 0.7 & 13.8 & 0.8 & 0.9 & 7.8 & 31.1 & 1.4 & 0.1\end{array}$ $\begin{array}{lllllllllllllllll}0.5 & 0.2 & 9.8 & 0.3 & 13.8 & 13.4 & 2.2 & 0.1 & 5.9 & 2.6 & 3.8 & -0.6 & 4.6 & 11.6 & 29.9 & 1.7 & 0.1\end{array}$ $\begin{array}{lllllllllllllllll}1.3 & 0.3 & 10.3 & 0.2 & 13.0 & 10.6 & 1.2 & 0.1 & 4.1 & 2.9 & 2.9 & 1.0 & 2.5 & 20.8 & 25.8 & 2.9 & 0.1\end{array}$ $\begin{array}{lllllllllllllllll}1.3 & 0.3 & 11.5 & 0.1 & 9.1 & 5.1 & 1.3 & 0.1 & 2.2 & 1.7 & 3.0 & 3.2 & 2.8 & 18.1 & 35.2 & 4.8 & 0.2\end{array}$ $\begin{array}{lllllllllllllllll}2.2 & 0.3 & 10.2 & 0.1 & 8.6 & 4.4 & 1.0 & 0.0 & 1.8 & 1.1 & 8.8 & 1.0 & 3.5 & 9.2 & 45.7 & 1.8 & 0.3\end{array}$ $\begin{array}{lllllllllllllllllll}1.9 & 0.3 & 8.8 & 0.1 & 15.0 & 4.6 & 1.3 & 0.1 & 1.4 & 1.1 & 3.2 & 2.1 & 1.9 & 19.3 & 33.6 & 5.2 & 0.2\end{array}$ $\begin{array}{lllllllllllllllll}1.1 & 0.2 & 12.1 & 0.1 & 8.1 & 4.7 & 0.7 & 0.1 & 2.0 & 0.7 & 5.8 & 1.4 & 2.8 & 12.0 & 44.4 & 3.5 & 0.2\end{array}$ $\begin{array}{lllllllllllllllll}1.5 & 0.3 & 12.9 & 0.1 & 12.4 & 4.0 & 0.9 & 0.1 & 2.4 & 0.9 & 6.9 & 1.8 & 1.5 & 10.3 & 42.7 & 1.1 & 0.2\end{array}$ $\begin{array}{lllllllllllllllll}1.1 & 0.3 & 12.7 & 0.1 & 9.7 & 4.5 & 0.9 & 0.1 & 3.8 & 0.9 & 4.9 & 2.3 & 2.4 & 12.0 & 40.8 & 3.3 & 0.2\end{array}$

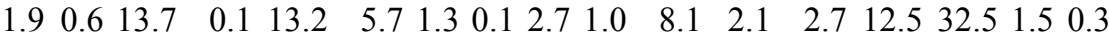
$\begin{array}{lllllllllllllllll}1.9 & 0.4 & 5.8 & 6.1 & 15.6 & 21.0 & 1.5 & 0.2 & 7.3 & 2.1 & 2.5 & 0.8 & 3.0 & 13.3 & 17.3 & 1.1 & 0.1\end{array}$ $\begin{array}{lllllllllllllllll}1.9 & 0.4 & 9.3 & 3.6 & 15.9 & 18.8 & 1.7 & 0.1 & 6.8 & 2.3 & 2.5 & 1.2 & 3.3 & 11.2 & 19.9 & 1.1 & 0.1\end{array}$ $\begin{array}{lllllllllllllllll}2.0 & 0.4 & 10.9 & 3.1 & 17.9 & 17.3 & 2.2 & 0.2 & 6.7 & 2.3 & 2.8 & 0.8 & 3.5 & 9.8 & 18.9 & 1.2 & 0.0\end{array}$ $\begin{array}{lllllllllllllllll}1.9 & 0.5 & 8.8 & 5.3 & 15.3 & 17.7 & 1.7 & 0.2 & 7.1 & 2.1 & 2.7 & 0.5 & 3.2 & 12.8 & 18.5 & 1.8 & 0.1\end{array}$ $\begin{array}{lllllllllllllllll}1.8 & 0.4 & 10.1 & 16.8 & 11.7 & 10.6 & 1.5 & 0.1 & 2.9 & 1.1 & 3.4 & 2.5 & 2.1 & 12.1 & 20.5 & 2.2 & 0.2\end{array}$ $\begin{array}{lllllllllllllllll}1.5 & 0.3 & 7.6 & 8.8 & 12.5 & 7.0 & 1.2 & 0.1 & 2.8 & 1.1 & 3.9 & 2.2 & 2.7 & 9.6 & 36.3 & 2.1 & 0.2\end{array}$ $\begin{array}{lllllllllllllllll}1.6 & 0.3 & 9.0 & 31.9 & 15.6 & 5.7 & 1.8 & 0.1 & 3.5 & 0.9 & 4.7 & 2.2 & 2.9 & 2.7 & 15.9 & 1.0 & 0.2\end{array}$ $\begin{array}{lllllllllllllllll}1.9 & 0.3 & 7.3 & 0.1 & 13.1 & 5.0 & 1.2 & 0.1 & 1.5 & 0.8 & 4.2 & 1.1 & 2.2 & 11.6 & 47.2 & 2.3 & 0.3\end{array}$ 


\begin{tabular}{|c|c|c|}
\hline$\#$ & Abbreviation & Full name of political party / movement \\
\hline 1 & HZPČS & Hnutie za prosperujúce Česko + Slovensko \\
\hline 2 & SD & Sociálna demokracia \\
\hline 3 & ZRS & Združenie robotníkov Slovenska \\
\hline 4 & MK & $\begin{array}{l}\text { Magyar Koalíció - Mad’arská koalícia, Magyar Kereszténydemokrata } \\
\text { Mozgalom - Mad’arské krest'anskodemokratické hnutie, gyüttélés } \\
\text { Spolužitie, Magyar Polgári Párt - Mad'arská občianska strana }\end{array}$ \\
\hline 5 & SP.VOL'BA & $\begin{array}{l}\text { Spoločná vol'ba - Strana demokratickej l'avice, Sociálnodemokratická } \\
\text { strana Slovenska, Strana zelených na Slovensku, Hnutie } \\
\text { pol'nohospodárov Slovenskej republiky }\end{array}$ \\
\hline 6 & DÚ & Demokratická únia Slovenska \\
\hline 7 & SPK & $\begin{array}{l}\text { Strana proti korupcii - za poriadok, prácu a peniaze pre všetkých } \\
\text { slušných občanov }\end{array}$ \\
\hline 8 & ZPR-REP & Združenie pre republiku - Republikáni \\
\hline 9 & DS & Demokratická strana \\
\hline 10 & NS & Nové Slovensko \\
\hline 11 & KSS & Komunistická strana Slovenska \\
\hline 12 & ROISR & Rómska občianska iniciatíva v Slovenskej republike \\
\hline 13 & SNS & Slovenská národná strana \\
\hline 14 & $\mathrm{KDH}$ & Krest’anskodemokratické hnutie \\
\hline 15 & HZDS-RSS & $\begin{array}{l}\text { Koalícia Hnutie za demokratické Slovensko a Rol'nícka strana } \\
\text { Slovenska }\end{array}$ \\
\hline 16 & KSÚ & Krest’anská sociálna únia Slovenska \\
\hline 17 & RSDSS & Reálna sociálnodemokratická strana Slovákov \\
\hline
\end{tabular}


Appendix 2 - 1998 Slovak Election - Voting Results and List of Political Parties 


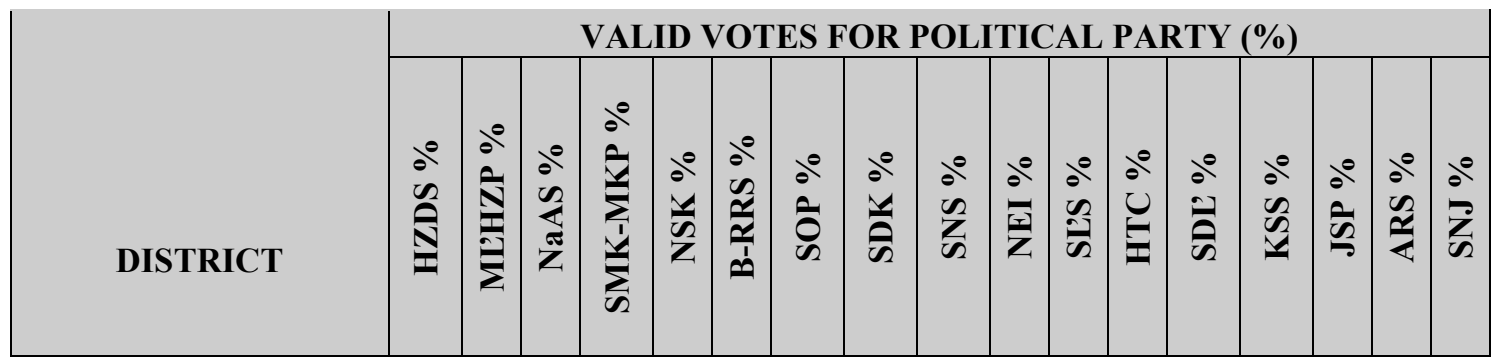

Bratislavský Region

Bratislava I

Bratislava II

Bratislava III

Bratislava IV

Bratislava $\mathrm{V}$

Malacky

Pezinok

Senec

\section{Trnavský Region}

Dunajská Streda

Galanta

Hlohovec

Piešt'any

Senica

Skalica

Trnava

\section{Trenčiansky Region}

Bánovce nad Bebravou

Ilava

Myjava

Nové Mesto nad Váhom

Partizánske

Považská Bystrica

Prievidza

Púchov

Trenčín

\section{Nitriansky Region}

Komárno

Levice

Nitra

Nové Zámky

Šal'a

Topol'čany

Zlaté Moravce

Žilinský Region

Bytča

Čadca

Dolný Kubín $\begin{array}{llllllllllllllllll}17.7 & 0.1 & 0.0 & 2.7 & 0.3 & 0.0 & 5.0 & 53.9 & 5.7 & 0.2 & 0.2 & 0.0 & 12.8 & 1.1 & 0.0 & 0.1 & 0.1\end{array}$ $\begin{array}{lllllllllllllllll}20.6 & 0.1 & 0.0 & 4.6 & 0.4 & 0.1 & 5.8 & 43.7 & 7.2 & 0.2 & 0.1 & 0.1 & 15.2 & 1.4 & 0.1 & 0.3 & 0.1\end{array}$ $\begin{array}{lllllllllllllllll}22.9 & 0.1 & 0.0 & 1.9 & 0.4 & 0.1 & 5.9 & 43.0 & 7.9 & 0.2 & 0.2 & 0.0 & 15.3 & 1.7 & 0.1 & 0.3 & 0.1\end{array}$ $\begin{array}{lllllllllllllllll}18.4 & 0.1 & 0.0 & 1.6 & 0.5 & 0.1 & 6.5 & 46.6 & 7.3 & 0.2 & 0.2 & 0.1 & 16.6 & 1.4 & 0.1 & 0.3 & 0.1\end{array}$ $\begin{array}{llllllllllllllllll}15.6 & 0.1 & 0.0 & 2.5 & 0.5 & 0.1 & 6.2 & 47.2 & 7.7 & 0.2 & 0.1 & 0.1 & 18.2 & 1.2 & 0.1 & 0.3 & 0.1\end{array}$ $\begin{array}{lllllllllllllllll}24.5 & 0.0 & 0.1 & 0.2 & 0.8 & 0.2 & 6.8 & 36.8 & 9.0 & 0.3 & 0.3 & 0.0 & 15.7 & 3.9 & 0.2 & 1.0 & 0.1\end{array}$ $\begin{array}{llllllllllllllllll}28.7 & 0.0 & 0.0 & 0.2 & 0.7 & 0.1 & 7.0 & 31.9 & 11.3 & 0.2 & 0.3 & 0.1 & 17.1 & 1.8 & 0.1 & 0.4 & 0.1\end{array}$ $\begin{array}{lllllllllllllllll}19.7 & 0.2 & 0.0 & 17.7 & 0.6 & 0.3 & 5.4 & 33.8 & 6.5 & 0.2 & 0.2 & 0.1 & 12.3 & 2.1 & 0.1 & 0.4 & 0.1\end{array}$

$\begin{array}{lllllllllllllllll}2.8 & 0.5 & 0.0 & 79.3 & 0.1 & 0.0 & 1.4 & 11.8 & 0.6 & 0.0 & 0.0 & 0.0 & 2.6 & 0.5 & 0.0 & 0.1 & 0.0\end{array}$ $\begin{array}{lllllllllllllllll}19.2 & 0.4 & 0.1 & 35.9 & 0.5 & 0.1 & 4.1 & 21.2 & 5.5 & 0.2 & 0.1 & 0.0 & 9.1 & 2.7 & 0.1 & 0.8 & 0.1\end{array}$ $\begin{array}{llllllllllllllllll}37.3 & 0.0 & 0.1 & 0.1 & 0.5 & 0.2 & 5.6 & 24.6 & 11.6 & 0.2 & 0.3 & 0.0 & 15.0 & 2.9 & 0.1 & 1.4 & 0.1\end{array}$ $\begin{array}{lllllllllllllllllll}33.3 & 0.0 & 0.0 & 0.2 & 0.6 & 0.1 & 6.2 & 31.6 & 10.8 & 0.2 & 0.3 & 0.0 & 13.9 & 1.7 & 0.1 & 0.7 & 0.1\end{array}$ $\begin{array}{lllllllllllllllll}29.5 & 0.0 & 0.1 & 0.2 & 1.0 & 0.3 & 5.8 & 34.1 & 6.7 & 0.3 & 0.4 & 0.1 & 16.2 & 3.5 & 0.2 & 1.2 & 0.2\end{array}$ $\begin{array}{lllllllllllllllll}19.0 & 0.0 & 0.1 & 0.1 & 1.4 & 0.3 & 4.4 & 49.3 & 4.6 & 0.2 & 0.4 & 0.1 & 12.6 & 5.5 & 0.2 & 1.6 & 0.1\end{array}$ $\begin{array}{lllllllllllllllllll}32.3 & 0.0 & 0.0 & 0.1 & 0.6 & 0.2 & 4.6 & 30.2 & 10.9 & 0.2 & 0.3 & 0.1 & 17.0 & 2.4 & 0.1 & 0.8 & 0.1\end{array}$

$\begin{array}{lllllllllllllllll}40.5 & 0.0 & 0.0 & 0.0 & 0.7 & 0.2 & 2.8 & 17.7 & 10.9 & 0.4 & 0.4 & 0.1 & 19.9 & 4.0 & 0.1 & 2.0 & 0.1\end{array}$ $\begin{array}{llllllllllllllllll}44.2 & 0.0 & 0.0 & 0.0 & 0.6 & 0.1 & 5.7 & 18.9 & 13.9 & 0.3 & 0.3 & 0.0 & 11.9 & 2.0 & 0.1 & 1.8 & 0.1\end{array}$ $\begin{array}{lllllllllllllllll}36.7 & 0.0 & 0.1 & 0.0 & 1.4 & 0.2 & 5.9 & 19.2 & 8.5 & 0.4 & 0.2 & 0.1 & 20.0 & 4.1 & 0.2 & 2.8 & 0.2\end{array}$ $\begin{array}{lllllllllllllllll}39.1 & 0.0 & 0.1 & 0.1 & 0.8 & 0.1 & 5.7 & 23.1 & 9.0 & 0.2 & 0.5 & 0.1 & 15.9 & 3.8 & 0.1 & 1.1 & 0.2\end{array}$ $\begin{array}{llllllllllllllllll}36.4 & 0.0 & 0.0 & 0.1 & 0.4 & 0.1 & 5.1 & 22.0 & 13.7 & 0.3 & 0.5 & 0.1 & 16.8 & 2.9 & 0.1 & 1.4 & 0.1\end{array}$ $\begin{array}{lllllllllllllllll}46.9 & 0.0 & 0.0 & 0.0 & 0.4 & 0.1 & 4.3 & 16.7 & 17.0 & 0.2 & 0.6 & 0.1 & 9.8 & 2.3 & 0.1 & 1.4 & 0.1\end{array}$ $\begin{array}{llllllllllllllllll}37.9 & 0.0 & 0.0 & 0.1 & 0.6 & 0.1 & 6.3 & 18.7 & 15.8 & 0.2 & 0.3 & 0.0 & 15.9 & 2.6 & 0.1 & 1.2 & 0.2\end{array}$ $\begin{array}{llllllllllllllllll}45.7 & 0.0 & 0.1 & 0.2 & 0.4 & 0.1 & 5.5 & 18.4 & 14.8 & 0.3 & 0.4 & 0.0 & 9.4 & 2.3 & 0.1 & 2.3 & 0.2\end{array}$ $\begin{array}{lllllllllllllllll}38.5 & 0.0 & 0.0 & 0.1 & 0.7 & 0.1 & 7.7 & 25.5 & 10.1 & 0.3 & 0.4 & 0.1 & 13.6 & 2.1 & 0.1 & 0.6 & 0.1\end{array}$

$\begin{array}{lllllllllllllllll}6.5 & 0.7 & 0.1 & 66.4 & 0.2 & 0.0 & 2.9 & 15.2 & 1.7 & 0.1 & 0.1 & 0.1 & 4.6 & 1.0 & 0.1 & 0.4 & 0.1\end{array}$ $\begin{array}{lllllllllllllllll}18.9 & 0.4 & 0.1 & 25.6 & 0.5 & 0.1 & 6.1 & 23.2 & 5.9 & 0.2 & 0.3 & 0.1 & 15.5 & 2.1 & 0.1 & 0.9 & 0.1\end{array}$ $\begin{array}{lllllllllllllllll}31.1 & 0.2 & 0.1 & 6.3 & 0.6 & 0.1 & 5.8 & 25.1 & 9.9 & 0.2 & 0.2 & 0.0 & 17.2 & 2.2 & 0.1 & 0.8 & 0.1\end{array}$ $\begin{array}{lllllllllllllllll}19.2 & 0.5 & 0.1 & 36.0 & 0.3 & 0.1 & 4.3 & 19.9 & 6.3 & 0.1 & 0.1 & 0.0 & 10.5 & 1.7 & 0.1 & 0.5 & 0.1\end{array}$ $\begin{array}{lllllllllllllllll}15.1 & 0.5 & 0.1 & 34.4 & 0.4 & 0.2 & 4.9 & 24.8 & 4.9 & 0.2 & 0.1 & 0.0 & 11.6 & 2.2 & 0.1 & 0.6 & 0.1\end{array}$ $\begin{array}{lllllllllllllllll}42.9 & 0.0 & 0.0 & 0.1 & 0.5 & 0.1 & 4.3 & 20.0 & 12.1 & 0.2 & 0.4 & 0.0 & 14.4 & 3.3 & 0.1 & 1.1 & 0.2\end{array}$ $\begin{array}{lllllllllllllllll}42.4 & 0.0 & 0.0 & 0.9 & 0.5 & 0.2 & 4.6 & 17.8 & 15.3 & 0.2 & 0.5 & 0.0 & 13.2 & 2.9 & 0.1 & 1.2 & 0.1\end{array}$

$\begin{array}{llllllllllllllllll}49.5 & 0.0 & 0.0 & 0.0 & 0.5 & 0.1 & 3.3 & 15.0 & 19.0 & 0.1 & 0.7 & 0.0 & 7.6 & 1.9 & 0.1 & 2.0 & 0.2\end{array}$ $\begin{array}{llllllllllllllllll}54.6 & 0.0 & 0.0 & 0.0 & 0.4 & 0.1 & 3.0 & 12.5 & 16.0 & 0.1 & 0.5 & 0.0 & 7.8 & 1.8 & 0.1 & 2.9 & 0.2\end{array}$ $\begin{array}{llllllllllllllllll}30.2 & 0.0 & 0.0 & 0.1 & 0.9 & 0.1 & 6.7 & 30.1 & 11.7 & 0.3 & 0.8 & 0.1 & 14.1 & 2.9 & 0.1 & 1.7 & 0.2\end{array}$ 
Kysucké Nové Mesto

Liptovský Mikuláš

Martin

Námestovo

Ružomberok

Turčianske Teplice

Tvrdošín

Žilina

Banskobystrický Region

Banská Bystrica

Banská Štiavnica

Brezno

Detva

Krupina

Lučenec

Poltár

Revúca

Rimavská Sobota

Vel'ký Krtíš

Zvolen

Žarnovica

Žiar nad Hronom

Prešovský Region

Bardejov

Humenné

Kežmarok

Levoča

Medzilaborce

Poprad

Prešov

Sabinov

Snina

Stará Lubovňa

Stropkov

Svidník

Vranov nad Topl'ou

Košický Region

Gelnica

Košice I

Košice II

Košice III

Košice IV

Košice - okolie

Michalovce

Rožňava

Sobrance $\begin{array}{lllllllllllllllll}49.9 & 0.0 & 0.0 & 0.0 & 0.3 & 0.1 & 2.9 & 11.6 & 21.6 & 0.3 & 0.4 & 0.1 & 9.3 & 2.3 & 0.1 & 1.0 & 0.2\end{array}$ $\begin{array}{llllllllllllllllll}29.3 & 0.0 & 0.0 & 0.1 & 0.5 & 0.1 & 8.8 & 21.1 & 12.3 & 0.2 & 0.2 & 0.1 & 22.2 & 3.5 & 0.1 & 1.4 & 0.1\end{array}$ $\begin{array}{lllllllllllllllll}26.6 & 0.0 & 0.0 & 0.2 & 0.8 & 0.2 & 10.3 & 24.4 & 11.2 & 0.3 & 0.2 & 0.2 & 19.1 & 3.8 & 0.1 & 2.5 & 0.1\end{array}$ $\begin{array}{lllllllllllllllll}39.3 & 0.0 & 0.0 & 0.0 & 0.7 & 0.2 & 4.9 & 27.4 & 14.7 & 0.3 & 0.9 & 0.0 & 7.5 & 1.6 & 0.1 & 2.0 & 0.3\end{array}$ $\begin{array}{lllllllllllllllll}30.5 & 0.0 & 0.0 & 0.2 & 0.5 & 0.1 & 5.7 & 30.1 & 14.3 & 0.3 & 0.5 & 0.1 & 13.8 & 2.1 & 0.1 & 1.6 & 0.1\end{array}$ $\begin{array}{lllllllllllllllll}32.0 & 0.1 & 0.0 & 0.2 & 0.7 & 0.2 & 7.6 & 16.7 & 11.1 & 0.3 & 0.2 & 0.1 & 21.4 & 5.8 & 0.1 & 3.3 & 0.2\end{array}$ $\begin{array}{lllllllllllllllll}35.9 & 0.0 & 0.0 & 0.0 & 0.6 & 0.1 & 3.0 & 25.8 & 19.2 & 0.3 & 1.2 & 0.1 & 7.0 & 1.2 & 0.1 & 4.9 & 0.5\end{array}$ $\begin{array}{llllllllllllllllll}36.4 & 0.0 & 0.0 & 0.1 & 0.4 & 0.1 & 4.5 & 21.6 & 23.7 & 0.2 & 0.3 & 0.1 & 9.8 & 1.5 & 0.0 & 1.0 & 0.1\end{array}$

$\begin{array}{lllllllllllllllll}22.1 & 0.0 & 0.0 & 0.3 & 0.5 & 0.1 & 5.7 & 30.1 & 10.1 & 0.2 & 0.3 & 0.1 & 26.1 & 2.7 & 0.1 & 1.5 & 0.1\end{array}$ $\begin{array}{lllllllllllllllll}34.1 & 0.0 & 0.1 & 0.1 & 0.6 & 0.2 & 8.9 & 21.0 & 10.3 & 0.1 & 0.4 & 0.1 & 17.0 & 4.1 & 0.1 & 2.9 & 0.2\end{array}$ $\begin{array}{llllllllllllllllll}31.9 & 0.1 & 0.2 & 0.1 & 0.6 & 0.2 & 6.3 & 17.4 & 14.8 & 0.2 & 0.3 & 0.1 & 21.8 & 3.6 & 0.1 & 2.4 & 0.1\end{array}$ $\begin{array}{llllllllllllllllll}42.4 & 0.1 & 0.1 & 0.1 & 0.4 & 0.1 & 4.8 & 14.8 & 16.7 & 0.2 & 0.6 & 0.0 & 13.4 & 3.6 & 0.1 & 2.5 & 0.2\end{array}$ $\begin{array}{lllllllllllllllll}31.2 & 0.0 & 0.2 & 0.3 & 0.4 & 0.2 & 6.0 & 19.2 & 12.2 & 0.3 & 0.8 & 0.1 & 22.8 & 3.7 & 0.2 & 2.4 & 0.2\end{array}$ $\begin{array}{lllllllllllllllll}18.7 & 0.6 & 0.1 & 23.2 & 0.5 & 0.2 & 7.5 & 21.8 & 6.2 & 0.2 & 0.2 & 0.1 & 15.5 & 4.0 & 0.1 & 1.2 & 0.1\end{array}$ $\begin{array}{lllllllllllllllll}33.5 & 0.0 & 0.1 & 0.1 & 0.5 & 0.3 & 7.9 & 14.8 & 11.2 & 0.2 & 0.4 & 0.0 & 18.6 & 8.4 & 0.1 & 3.5 & 0.2\end{array}$ $\begin{array}{lllllllllllllllll}21.3 & 0.5 & 0.2 & 10.2 & 0.3 & 0.6 & 10.1 & 19.0 & 6.2 & 0.2 & 0.2 & 0.1 & 22.0 & 5.1 & 0.2 & 3.6 & 0.3\end{array}$ $\begin{array}{lllllllllllllllll}14.2 & 1.4 & 0.1 & 35.0 & 0.4 & 0.2 & 7.0 & 15.4 & 5.8 & 0.1 & 0.1 & 0.1 & 13.5 & 4.2 & 0.2 & 2.1 & 0.2\end{array}$ $\begin{array}{lllllllllllllllll}20.3 & 0.8 & 0.1 & 25.0 & 0.3 & 0.2 & 6.0 & 19.1 & 5.1 & 0.2 & 0.1 & 0.1 & 16.0 & 5.2 & 0.1 & 1.2 & 0.2\end{array}$ $\begin{array}{llllllllllllllllll}26.4 & 0.0 & 0.1 & 0.3 & 0.6 & 0.1 & 6.9 & 24.4 & 11.7 & 0.2 & 0.2 & 0.1 & 23.3 & 3.7 & 0.1 & 1.9 & 0.0\end{array}$ $\begin{array}{lllllllllllllllll}46.9 & 0.0 & 0.1 & 0.1 & 0.9 & 0.1 & 4.3 & 13.5 & 12.7 & 0.2 & 0.5 & 0.0 & 14.1 & 4.2 & 0.1 & 2.0 & 0.2\end{array}$ $\begin{array}{llllllllllllllllll}37.6 & 0.1 & 0.1 & 0.2 & 0.6 & 0.1 & 5.7 & 19.0 & 16.0 & 0.3 & 0.4 & 0.1 & 15.5 & 3.0 & 0.1 & 1.0 & 0.3\end{array}$

$\begin{array}{lllllllllllllllll}29.6 & 0.1 & 0.1 & 0.1 & 0.4 & 0.1 & 9.5 & 28.7 & 5.7 & 0.1 & 0.3 & 0.1 & 18.8 & 4.1 & 0.1 & 2.0 & 0.2\end{array}$ $\begin{array}{llllllllllllllllll}28.0 & 0.0 & 0.1 & 0.1 & 0.3 & 0.1 & 13.7 & 27.9 & 6.2 & 0.1 & 0.4 & 0.2 & 16.0 & 5.0 & 0.1 & 1.7 & 0.1\end{array}$ $\begin{array}{lllllllllllllllll}26.0 & 0.1 & 0.2 & 0.1 & 0.3 & 0.3 & 9.3 & 40.5 & 6.0 & 0.2 & 0.3 & 0.1 & 10.8 & 2.3 & 0.2 & 2.8 & 0.5\end{array}$ $\begin{array}{lllllllllllllllll}23.3 & 0.1 & 0.2 & 0.1 & 0.4 & 0.2 & 9.7 & 36.4 & 7.6 & 0.1 & 0.3 & 0.1 & 16.0 & 3.8 & 0.1 & 1.6 & 0.2\end{array}$ $\begin{array}{lllllllllllllllll}29.3 & 0.0 & 0.0 & 0.0 & 0.9 & 0.2 & 12.5 & 14.2 & 2.7 & 0.1 & 0.2 & 0.0 & 20.4 & 10.3 & 0.3 & 8.3 & 0.4\end{array}$ $\begin{array}{lllllllllllllllll}22.3 & 0.1 & 0.2 & 0.3 & 0.5 & 0.1 & 9.6 & 34.6 & 8.4 & 0.2 & 0.2 & 0.1 & 18.6 & 2.9 & 0.1 & 1.7 & 0.1\end{array}$ $\begin{array}{lllllllllllllllll}21.2 & 0.0 & 0.2 & 0.1 & 0.4 & 0.1 & 10.4 & 40.6 & 5.5 & 0.2 & 0.3 & 0.1 & 17.2 & 2.4 & 0.1 & 1.0 & 0.1\end{array}$ $\begin{array}{lllllllllllllllll}32.5 & 0.1 & 0.2 & 0.0 & 0.6 & 0.2 & 10.2 & 27.2 & 6.9 & 0.2 & 0.4 & 0.1 & 13.0 & 2.7 & 0.2 & 5.3 & 0.2\end{array}$ $\begin{array}{lllllllllllllllll}36.0 & 0.0 & 0.1 & 0.1 & 0.4 & 0.1 & 13.1 & 17.3 & 6.1 & 0.2 & 0.3 & 0.1 & 13.8 & 7.3 & 0.2 & 4.7 & 0.2\end{array}$ $\begin{array}{lllllllllllllllll}37.2 & 0.1 & 0.2 & 0.1 & 0.6 & 0.2 & 9.0 & 23.6 & 6.0 & 0.2 & 0.4 & 0.1 & 15.6 & 3.3 & 0.2 & 3.0 & 0.4\end{array}$ $\begin{array}{lllllllllllllllll}41.1 & 0.1 & 0.1 & 0.0 & 0.4 & 0.2 & 9.6 & 19.9 & 6.2 & 0.2 & 0.2 & 0.0 & 13.0 & 5.0 & 0.1 & 3.6 & 0.2\end{array}$ $\begin{array}{lllllllllllllllll}41.8 & 0.1 & 0.1 & 0.0 & 0.3 & 0.1 & 9.9 & 17.3 & 3.8 & 0.1 & 0.2 & 0.0 & 17.1 & 6.6 & 0.1 & 2.2 & 0.2\end{array}$ $\begin{array}{lllllllllllllllll}31.7 & 0.1 & 0.1 & 0.1 & 0.4 & 0.2 & 11.4 & 21.8 & 8.3 & 0.1 & 0.3 & 0.9 & 15.1 & 6.7 & 0.2 & 2.5 & 0.3\end{array}$

$\begin{array}{lllllllllllllllll}35.0 & 0.2 & 0.2 & 0.1 & 0.5 & 0.3 & 12.5 & 17.2 & 7.5 & 0.2 & 0.3 & 0.1 & 15.5 & 7.4 & 0.2 & 2.9 & 0.2\end{array}$ $\begin{array}{llllllllllllllllll}13.3 & 0.2 & 0.1 & 4.0 & 0.3 & 0.1 & 23.8 & 38.8 & 4.0 & 0.1 & 0.1 & 0.1 & 12.9 & 1.9 & 0.1 & 0.2 & 0.1\end{array}$ $\begin{array}{lllllllllllllllll}15.1 & 0.2 & 0.4 & 2.5 & 0.3 & 0.0 & 24.3 & 35.6 & 4.2 & 0.1 & 0.1 & 0.0 & 14.8 & 1.9 & 0.1 & 0.4 & 0.0\end{array}$ $\begin{array}{llllllllllllllllll}13.0 & 0.2 & 0.1 & 2.1 & 0.2 & 0.1 & 28.4 & 33.7 & 4.5 & 0.1 & 0.1 & 0.0 & 15.2 & 1.7 & 0.1 & 0.4 & 0.1\end{array}$ $\begin{array}{llllllllllllllllll}14.3 & 0.1 & 0.2 & 3.6 & 0.3 & 0.1 & 25.4 & 35.9 & 4.1 & 0.1 & 0.1 & 0.0 & 13.6 & 1.7 & 0.1 & 0.3 & 0.1\end{array}$ $\begin{array}{llllllllllllllllll}17.7 & 0.4 & 0.3 & 13.2 & 0.4 & 0.2 & 21.9 & 27.1 & 4.0 & 0.1 & 0.2 & 0.1 & 10.7 & 2.9 & 0.1 & 0.6 & 0.2\end{array}$ $\begin{array}{llllllllllllllllll}27.2 & 0.1 & 0.1 & 7.8 & 0.3 & 0.1 & 13.2 & 21.7 & 6.6 & 0.1 & 0.1 & 0.1 & 16.9 & 3.8 & 0.1 & 1.5 & 0.2\end{array}$ $\begin{array}{lllllllllllllllll}17.2 & 0.6 & 0.2 & 25.2 & 0.4 & 0.2 & 14.2 & 17.4 & 4.3 & 0.1 & 0.1 & 0.1 & 14.2 & 4.3 & 0.2 & 1.2 & 0.2\end{array}$ $\begin{array}{lllllllllllllllll}39.7 & 0.0 & 0.1 & 0.0 & 0.3 & 0.2 & 12.0 & 17.2 & 8.0 & 0.2 & 0.3 & 0.1 & 15.4 & 4.0 & 0.2 & 2.0 & 0.3\end{array}$ 


\begin{tabular}{|r|l|l|}
\hline$\#$ & Abbreviation & \multicolumn{1}{|c|}{ Full name of political party / movement } \\
\hline 1 & HZDS & Hnutie za demokratické Slovensko \\
\hline & & $\begin{array}{l}\text { Mad'arské l'udové hnutie za zmierenie a prosperitu -Magyar } \\
\text { Népi Mozgalom a Megbékélésért és a Jólétért }\end{array}$ \\
\hline 3 & NaAS & Národná alternatíva Slovenska \\
\hline 4 & SMK-MKP & Strana mad'arskej koalície - Magyar Koalíció Pártja \\
\hline 5 & NSK & Naše Slovensko \\
\hline 6 & B-RRS & Béčko - Revolučná robotnícka strana \\
\hline 7 & SOP & Strana občianskeho porozumenia \\
\hline 8 & SDK & Slovenská demokratická koalícia \\
\hline 9 & SNS & Slovenská národná strana \\
\hline 10 & NEI & Nezávislá iniciatíva (NEI) Slovenskej republiky \\
\hline 11 & SLS & Slovenská l’udová strana \\
\hline 12 & HTC & Hnutie tretej cesty \\
\hline 13 & SDL & Strana demokratickej l'avice \\
\hline 14 & KSS & Komunistická strana Slovenska \\
\hline 15 & JSP & Jednotná strana pracujúcich Slovenska \\
\hline 16 & ZRS & Združenie robotníkov Slovenska \\
\hline 17 & SNJ & Slovenská národná jednota \\
\hline
\end{tabular}


Appendix 3 - 2002 Slovak Election - Voting Results and List of Political Parties 


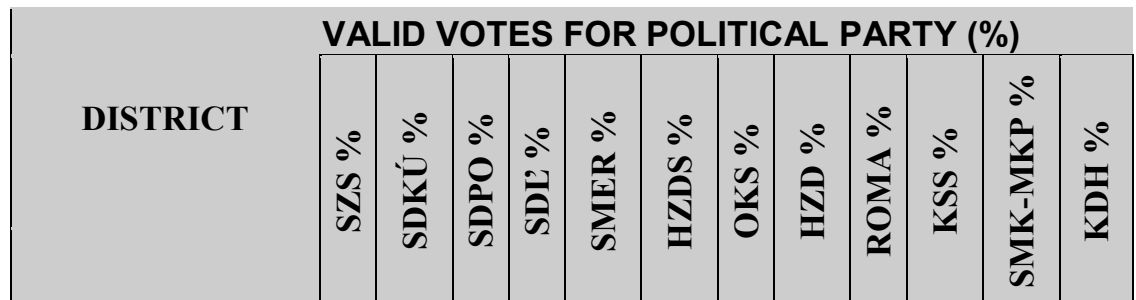

\section{Bratislavský Region}

Bratislava I

Bratislava II

Bratislava III

Bratislava IV

Bratislava $\mathrm{V}$

Malacky

Pezinok

Senec

\section{Trnavský Region}

Dunajská Streda

Galanta

Hlohovec

Piešt’any

Senica

Skalica

Trnava $\begin{array}{llllllllllll}0.8 & 40.7 & 0.1 & 1.0 & 8.9 & 11.6 & 1.2 & 2.8 & 0.0 & 2.9 & 5.9 & 10.6\end{array}$ $\begin{array}{llllllllllll}0.9 & 33.6 & 0.1 & 1.0 & 11.7 & 13.6 & 0.6 & 3.0 & 0.0 & 3.8 & 8.7 & 7.0\end{array}$ $\begin{array}{llllllllllll}1.0 & 33.2 & 0.1 & 1.0 & 12.3 & 14.8 & 0.8 & 3.2 & 0.0 & 4.6 & 4.4 & 7.8\end{array}$ $\begin{array}{llllllllllll}0.9 & 36.4 & 0.1 & 0.9 & 13.1 & 11.4 & 0.8 & 2.9 & 0.0 & 3.9 & 4.2 & 8.0\end{array}$ $\begin{array}{llllllllllll}1.1 & 35.7 & 0.1 & 1.0 & 13.7 & 10.3 & 0.8 & 2.7 & 0.0 & 3.8 & 5.9 & 6.5\end{array}$ $\begin{array}{llllllllllll}1.2 & 24.5 & 0.2 & 1.2 & 16.7 & 17.5 & 0.2 & 3.8 & 0.1 & 6.6 & 0.7 & 7.2\end{array}$ $\begin{array}{llllllllllll}1.0 & 23.9 & 0.2 & 1.2 & 16.0 & 19.7 & 0.5 & 4.5 & 0.0 & 4.4 & 0.9 & 8.2\end{array}$ $\begin{array}{llllllllllll}0.9 & 20.1 & 0.1 & 1.1 & 10.6 & 13.4 & 0.4 & 3.2 & 0.0 & 4.0 & 25.9 & 5.9\end{array}$

$\begin{array}{rrrrrrrrrrrr}0.6 & 4.0 & 0.1 & 0.3 & 1.8 & 1.8 & 0.1 & 0.3 & 0.1 & 0.7 & 86.2 & 0.7 \\ 0.8 & 9.6 & 0.1 & 0.8 & 10.2 & 13.3 & 0.2 & 2.9 & 0.1 & 4.0 & 42.9 & 3.5 \\ 0.9 & 11.6 & 0.4 & 1.1 & 18.9 & 29.4 & 0.3 & 4.9 & 0.1 & 6.2 & 0.4 & 9.7 \\ 0.9 & 17.7 & 1.1 & 1.3 & 15.6 & 24.5 & 0.3 & 4.8 & 0.0 & 4.1 & 0.7 & 10.1 \\ 1.4 & 17.3 & 0.3 & 2.5 & 17.7 & 22.9 & 0.2 & 2.8 & 0.1 & 7.2 & 0.4 & 11.3 \\ 1.3 & 23.9 & 0.2 & 2.6 & 17.6 & 13.6 & 0.3 & 2.2 & 0.1 & 8.7 & 0.4 & 13.5 \\ 1.0 & 16.4 & 0.2 & 1.2 & 18.3 & 22.7 & 0.3 & 6.5 & 0.1 & 4.8 & 0.5 & 11.4\end{array}$

Trenčiansky Region

Bánovce nad

Bebravou

$\begin{array}{lllllllllllll}0.9 & 7.3 & 0.1 & 2.5 & 17.5 & 29.7 & 0.2 & 3.5 & 0.0 & 9.2 & 0.1 & 9.2\end{array}$

Ilava

$\begin{array}{llllllllllll}1.5 & 10.0 & 0.1 & 1.3 & 16.5 & 33.2 & 0.2 & 3.8 & 0.0 & 5.6 & 0.2 & 8.3\end{array}$

Myjava

$\begin{array}{llllllllllll}1.1 & 14.2 & 0.3 & 2.6 & 17.6 & 30.1 & 0.4 & 4.1 & 0.0 & 6.0 & 0.1 & 2.0\end{array}$

Nové Mesto nad

Váhom

$\begin{array}{llllllllllll}1.3 & 13.2 & 0.4 & 2.1 & 14.5 & 28.3 & 0.3 & 6.1 & 0.1 & 6.8 & 0.3 & 8.3\end{array}$

$\begin{array}{llllllllllll}0.8 & 10.0 & 0.2 & 1.6 & 16.9 & 27.1 & 0.2 & 3.6 & 0.0 & 6.7 & 0.3 & 10.8\end{array}$

Partizánske

$\begin{array}{llllllllllll}1.5 & 8.4 & 0.1 & 0.9 & 13.6 & 37.6 & 0.2 & 3.8 & 0.0 & 5.6 & 0.2 & 7.9\end{array}$

$\begin{array}{llllllllllll}1.0 & 10.5 & 0.1 & 1.8 & 16.2 & 29.6 & 0.3 & 3.8 & 0.1 & 6.6 & 0.5 & 6.1\end{array}$

Prievidza

$\begin{array}{llllllllllll}0.9 & 10.1 & 0.1 & 1.1 & 15.4 & 38.1 & 0.2 & 3.1 & 0.0 & 4.3 & 0.2 & 8.9\end{array}$

Púchov

$\begin{array}{llllllllllll}0.9 & 15.8 & 0.1 & 1.3 & 15.5 & 30.0 & 0.4 & 3.9 & 0.0 & 5.2 & 0.5 & 9.8\end{array}$

\section{Nitriansky Region}

Komárno

$\begin{array}{llllllllllll}0.7 & 5.0 & 0.1 & 0.4 & 4.3 & 4.3 & 0.2 & 1.1 & 0.1 & 1.7 & 74.6 & 0.8\end{array}$

Levice

$\begin{array}{llllllllllll}0.9 & 10.5 & 0.1 & 1.3 & 12.3 & 13.4 & 0.3 & 3.0 & 0.2 & 5.2 & 31.6 & 4.8\end{array}$

Nitra

Nové Zámky

Šal'a

Topol'čany

$\begin{array}{llllllllllll}0.9 & 13.8 & 0.1 & 1.4 & 16.6 & 24.5 & 0.4 & 3.5 & 0.0 & 4.6 & 8.1 & 7.5\end{array}$

$\begin{array}{llllllllllll}0.7 & 7.6 & 0.1 & 0.9 & 10.1 & 14.5 & 0.2 & 1.9 & 0.1 & 3.1 & 43.1 & 3.6\end{array}$

$\begin{array}{llllllllllll}0.8 & 11.7 & 0.1 & 1.0 & 11.2 & 11.5 & 0.3 & 1.8 & 0.3 & 2.8 & 41.1 & 3.6\end{array}$

$\begin{array}{llllllllllll}0.9 & 8.5 & 0.2 & 1.3 & 17.5 & 32.6 & 0.2 & 4.2 & 0.0 & 7.1 & 0.2 & 9.5\end{array}$

$\begin{array}{llllllllllll}0.7 & 7.0 & 0.1 & 1.3 & 16.1 & 31.0 & 0.2 & 4.9 & 0.0 & 7.7 & 1.1 & 9.5\end{array}$

Žilinský Region

Bytča

$\begin{array}{llllllllllll}0.5 & 5.8 & 0.1 & 1.0 & 10.3 & 38.8 & 0.2 & 4.5 & 0.0 & 3.7 & 0.1 & 9.8\end{array}$

Čadca 


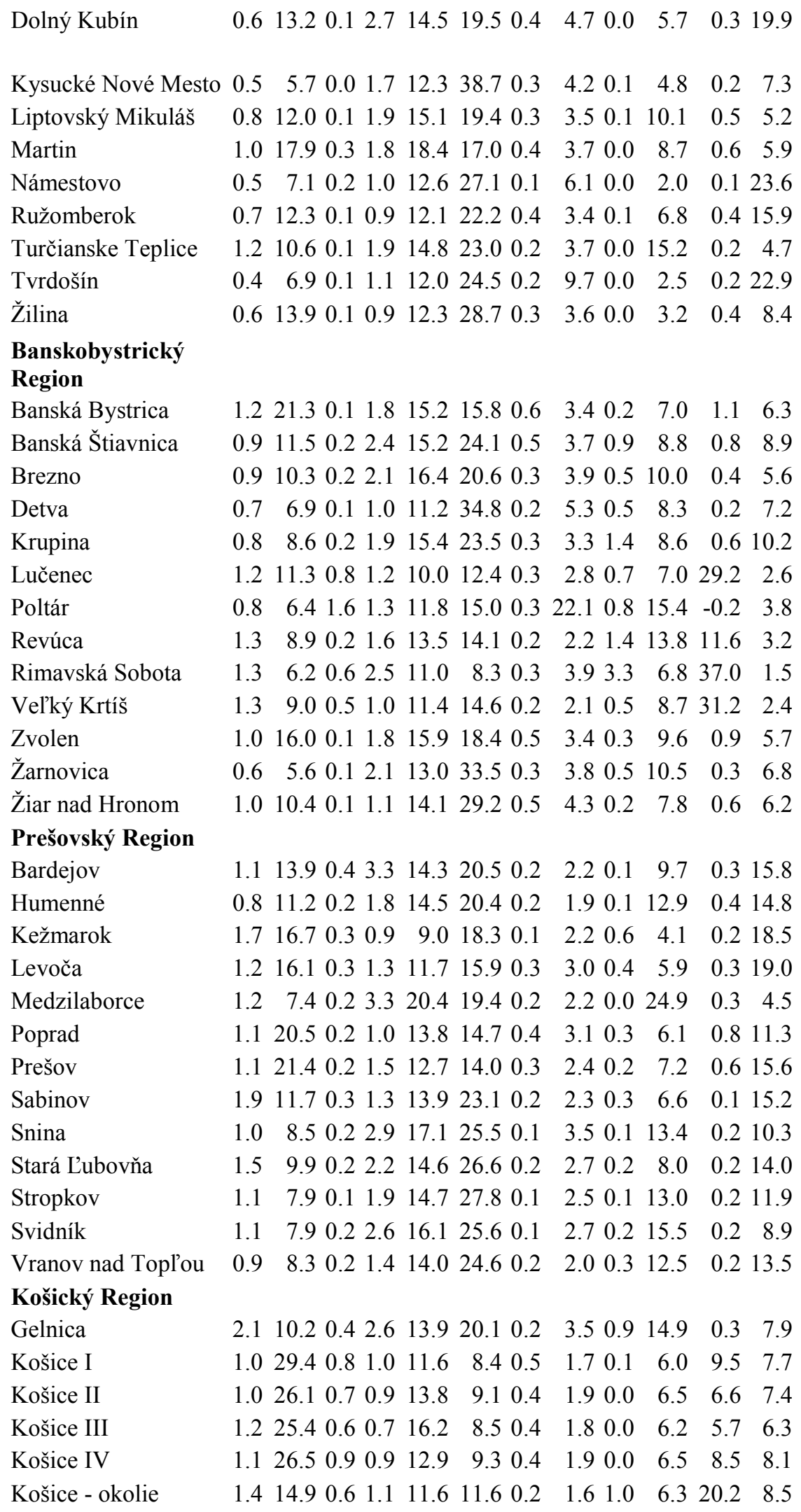




$\begin{array}{lrrrrrrrrrrrr}\text { Michalovce } & 1.0 & 10.7 & 0.5 & 1.4 & 14.7 & 20.0 & 0.2 & 1.7 & 0.6 & 11.2 & 8.2 & 8.6 \\ \text { Rožňava } & 1.0 & 9.1 & 0.2 & 1.8 & 10.2 & 9.5 & 0.4 & 1.5 & 0.4 & 8.2 & 36.9 & 1.4 \\ \text { Sobrance } & 1.3 & 6.7 & 0.3 & 1.5 & 15.6 & 28.2 & 0.2 & 2.4 & 0.3 & 11.5 & 0.1 & 9.5 \\ \text { Spišská Nová Ves } & 1.4 & 15.9 & 0.2 & 1.6 & 13.8 & 18.1 & 0.3 & 2.5 & 0.3 & 8.1 & 0.3 & 11.2 \\ \text { Trebišov } & 1.3 & 8.7 & 0.3 & 1.4 & 11.3 & 12.4 & 0.1 & 1.4 & 0.2 & 7.6 & 29.4 & 7.3\end{array}$

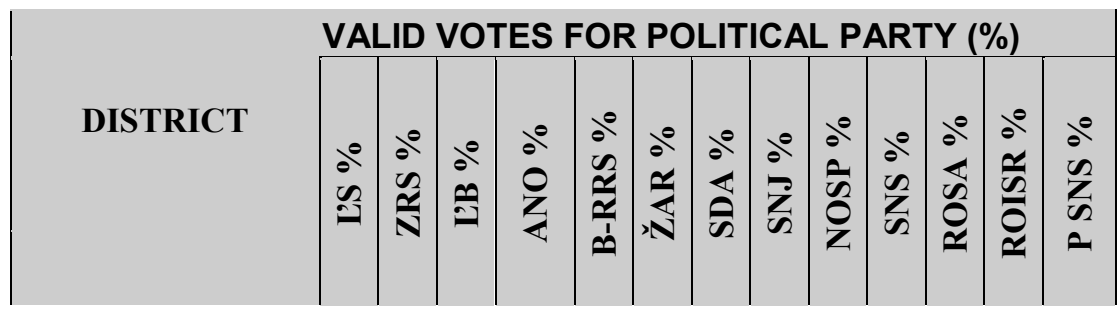

\section{Bratislavský Region}

Bratislava I

Bratislava II

Bratislava III

Bratislava IV

Bratislava V

Malacky

Pezinok

Senec

Trnavský Region

Dunajská Streda

Galanta

Hlohovec

Piešt'any

Senica

Skalica

Trnava

Trenčiansky Region

Bánovce nad

Bebravou

Ilava

Myjava

Nové Mesto nad

Váhom

Partizánske

Považská Bystrica

Prievidza

Púchov

Trenčín

Nitriansky Region

Komárno

Levice

Nitra $\begin{array}{lllllllllllll}0.0 & 0.1 & 0.1 & 5.4 & 0.0 & 0.2 & 3.1 & 0.1 & 0.3 & 3.0 & 0.1 & 0.0 & 1.1\end{array}$ $\begin{array}{lllllllllllll}0.0 & 0.1 & 0.2 & 6.7 & 0.0 & 0.4 & 2.8 & 0.1 & 0.3 & 3.6 & 0.1 & 0.0 & 1.6\end{array}$ $\begin{array}{llllllllllllll}0.0 & 0.1 & 0.1 & 6.9 & 0.0 & 0.4 & 2.7 & 0.2 & 0.4 & 3.9 & 0.2 & 0.0 & 2.0\end{array}$ $\begin{array}{llllllllllllll}0.0 & 0.1 & 0.2 & 8.0 & 0.0 & 0.5 & 3.2 & 0.1 & 0.4 & 3.2 & 0.1 & 0.0 & 1.6\end{array}$ $\begin{array}{llllllllllllll}0.0 & 0.1 & 0.1 & 8.1 & 0.0 & 0.5 & 3.3 & 0.1 & 0.3 & 3.3 & 0.1 & 0.0 & 2.1\end{array}$ $\begin{array}{lllllllllllllll}0.0 & 0.4 & 0.1 & 8.9 & 0.1 & 0.6 & 2.4 & 0.2 & 0.4 & 3.4 & 0.3 & 0.1 & 3.0\end{array}$ $\begin{array}{lllllllllllll}0.0 & 0.2 & 0.2 & 7.7 & 0.1 & 0.5 & 2.1 & 0.1 & 0.5 & 4.3 & 0.2 & 0.0 & 3.4\end{array}$ $\begin{array}{lllllllllllll}0.0 & 0.2 & 0.1 & 6.5 & 0.3 & 0.5 & 1.3 & 0.1 & 0.3 & 3.2 & 0.2 & 0.1 & 1.7\end{array}$

$\begin{array}{lllllllllllll}0.0 & 0.0 & 0.0 & 1.7 & 0.0 & 0.1 & 0.3 & 0.0 & 0.4 & 0.3 & 0.1 & 0.1 & 0.2\end{array}$ $\begin{array}{lllllllllllll}0.0 & 0.5 & 0.1 & 4.3 & 0.1 & 0.3 & 1.0 & 0.1 & 0.6 & 2.7 & 0.2 & 0.1 & 1.4\end{array}$ $\begin{array}{llllllllllllll}0.0 & 0.7 & 0.1 & 4.5 & 0.1 & 0.4 & 1.5 & 0.1 & 0.9 & 4.9 & 0.4 & 0.1 & 2.3\end{array}$ $\begin{array}{lllllllllllll}0.0 & 0.3 & 0.3 & 7.3 & 0.1 & 0.4 & 1.9 & 0.1 & 0.6 & 4.7 & 0.2 & 0.0 & 2.9\end{array}$ $\begin{array}{lllllllllllll}0.0 & 0.3 & 0.7 & 6.0 & 0.1 & 0.5 & 2.1 & 0.2 & 0.5 & 3.4 & 0.3 & 0.1 & 1.7\end{array}$ $\begin{array}{llllllllllllll}0.0 & 0.9 & 0.5 & 7.6 & 0.1 & 0.4 & 1.7 & 0.1 & 0.7 & 2.6 & 0.3 & 0.1 & 0.7\end{array}$ $\begin{array}{lllllllllllll}0.0 & 0.4 & 0.2 & 4.9 & 0.1 & 0.5 & 2.3 & 0.2 & 1.2 & 3.8 & 0.2 & 0.0 & 2.9\end{array}$ $\begin{array}{lllllllllllll}0.0 & 1.0 & 0.1 & 5.7 & 0.1 & 0.4 & 1.5 & 0.2 & 0.8 & 6.5 & 0.3 & 0.0 & 3.1\end{array}$ $\begin{array}{llllllllllllll}0.0 & 0.4 & 0.2 & 5.9 & 0.1 & 0.4 & 1.5 & 0.2 & 0.8 & 5.3 & 0.2 & 0.1 & 4.1\end{array}$ $\begin{array}{llllllllllllll}0.0 & 1.1 & 0.3 & 8.4 & 0.2 & 0.6 & 2.0 & 0.2 & 0.6 & 5.8 & 0.4 & 0.1 & 2.0\end{array}$

$\begin{array}{lllllllllllll}0.0 & 0.9 & 0.1 & 5.7 & 0.1 & 0.5 & 2.2 & 0.2 & 0.6 & 5.0 & 0.4 & 0.1 & 2.3\end{array}$ $\begin{array}{lllllllllllll}0.0 & 0.5 & 0.2 & 6.6 & 0.1 & 0.5 & 1.5 & 0.2 & 1.0 & 6.8 & 0.3 & 0.0 & 4.0\end{array}$ $\begin{array}{llllllllllllll}0.0 & 0.5 & 0.2 & 4.7 & 0.1 & 0.4 & 1.7 & 0.2 & 0.8 & 5.6 & 0.2 & 0.0 & 5.6\end{array}$ $\begin{array}{lllllllllllllll}0.0 & 0.8 & 0.1 & 7.3 & 0.1 & 0.5 & 1.8 & 0.2 & 1.2 & 6.3 & 0.2 & 0.0 & 4.8\end{array}$ $\begin{array}{llllllllllllll}0.0 & 0.9 & 0.1 & 4.6 & 0.1 & 0.4 & 1.2 & 0.2 & 0.8 & 5.0 & 0.2 & 0.0 & 4.0\end{array}$ $\begin{array}{llllllllllllll}0.0 & 0.3 & 0.1 & 5.8 & 0.1 & 0.5 & 1.8 & 0.2 & 1.0 & 3.9 & 0.2 & 0.0 & 2.7\end{array}$

$\begin{array}{lllllllllllll}0.0 & 0.1 & 0.0 & 3.6 & 0.0 & 0.1 & 0.5 & 0.0 & 0.8 & 0.8 & 0.1 & 0.1 & 0.4\end{array}$ $\begin{array}{llllllllllllll}0.0 & 0.4 & 0.2 & 8.0 & 0.1 & 0.3 & 1.4 & 0.1 & 1.1 & 2.6 & 0.4 & 0.2 & 1.6\end{array}$ $\begin{array}{lllllllllllll}0.0 & 0.4 & 0.2 & 6.7 & 0.1 & 0.3 & 1.5 & 0.1 & 1.1 & 4.8 & 0.3 & 0.2 & 3.1\end{array}$ 


\begin{tabular}{|c|c|c|c|}
\hline Nové Zámky & $\begin{array}{lll}0.0 & 0.3 & 0.1\end{array}$ & $\begin{array}{lllllllll}6.2 & 0.1 & 0.2 & 0.8 & 0.1 & 0.7 & 3.4 & 0.2 & 0.3\end{array}$ & 1.7 \\
\hline Šal'a & $\begin{array}{lll}0.0 & 0.3 & 0.2\end{array}$ & $\begin{array}{lllllllll}5.7 & 0.1 & 0.4 & 1.5 & 0.1 & 0.9 & 2.7 & 0.2 & 0.3\end{array}$ & 1.4 \\
\hline Topol'čany & $\begin{array}{lll}0.0 & 0.5 & 0.1\end{array}$ & $\begin{array}{lllllllll}5.8 & 0.1 & 0.4 & 1.2 & 0.2 & 0.5 & 5.5 & 0.2 & 0.0\end{array}$ & 3.1 \\
\hline laté Moravce & $\begin{array}{lll}0 & 0.6 & 0.1\end{array}$ & $\begin{array}{lllllllll}6.2 & 0.1 & 0.4 & 0.9 & 0.2 & 0.7 & 7.4 & 0.3 & 0.0\end{array}$ & 3.5 \\
\hline \multicolumn{4}{|l|}{ Žilinský Region } \\
\hline Bytča & $\begin{array}{lll}0 & 0.3 & 0.1\end{array}$ & $\begin{array}{lllllllll}3.9 & 0.0 & 0.3 & 0.9 & 0.2 & 0.8 & 3.3 & 0.2 & 0.0\end{array}$ & 15.1 \\
\hline adca & $\begin{array}{lll}0 & 0.7 & 0.1\end{array}$ & $\begin{array}{lllllllll}3.2 & 0.1 & 0.3 & 1.1 & 0.3 & 0.4 & 3.4 & 0.4 & 0.0\end{array}$ & 5.8 \\
\hline Dolný Kubín & $\begin{array}{lll}0.0 & 0.8 & 0.2\end{array}$ & $\begin{array}{lllllllll}6.8 & 0.1 & 0.5 & 1.5 & 0.2 & 1.7 & 3.2 & 0.2 & 0.0\end{array}$ & 3.4 \\
\hline ysucké $\mathrm{N}$ & $\begin{array}{lll}0.0 & 0.6 & 0.1\end{array}$ & $\begin{array}{lllllllll}4.3 & 0.1 & 0.3 & 0.7 & 0.2 & 1.0 & 3.6 & 0.3 & 0\end{array}$ & 13.2 \\
\hline Liptovský Mikuláš & $\begin{array}{lll}0.0 & 0.8 & 0.2\end{array}$ & $\begin{array}{lllllllll}15.2 & 0.1 & 0.5 & 2.4 & 0.1 & 2.5 & 3.0 & 0.3 & 0.0\end{array}$ & 5.6 \\
\hline Martin & $\begin{array}{lll}0.0 & 0.8 & 0.2\end{array}$ & $\begin{array}{lllllllll}9.9 & 0.1 & 0.5 & 2.3 & 0.1 & 0.7 & 2.7 & 0.3 & 0.0\end{array}$ & 6.5 \\
\hline Jámestovo & $\begin{array}{lll}0.0 & 1.3 & 0.1\end{array}$ & $\begin{array}{lllllllll}4.5 & 0.1 & 0.4 & 0.5 & 0.3 & 0.4 & 6.3 & 0.4 & 0.0\end{array}$ & 5.3 \\
\hline užomberok & $\begin{array}{lll}0.0 & 0.8 & 0.2\end{array}$ & $\begin{array}{lllllllll}8.9 & 0.1 & 0.5 & 1.4 & 0.2 & 1.2 & 6.3 & 0.4 & 0.1\end{array}$ & 4.7 \\
\hline určianske & $\begin{array}{lll}0.0 & 1.0 & 0.1\end{array}$ & $\begin{array}{lllllllll}9.1 & 0.0 & 0.5 & 1.6 & 0.2 & 0.8 & 3.4 & 0.5 & 0.0\end{array}$ & 6.9 \\
\hline vrdošín & $\begin{array}{lll}0.0 & 0.8 & 0.1\end{array}$ & $\begin{array}{lllllllll}4.4 & 0.1 & 0.3 & 0.7 & 0.4 & 0.9 & 6.7 & 0.2 & 0.0\end{array}$ & 4.9 \\
\hline Žilina & $\begin{array}{lll}0.0 & 0.3 & 0.1\end{array}$ & $\begin{array}{lllllllll}5.3 & 0.0 & 0.3 & 1.3 & 0.1 & 0.8 & 2.4 & 0.2 & 0.0\end{array}$ & 16.9 \\
\hline \multicolumn{4}{|l|}{$\begin{array}{l}\text { Banskobystrický } \\
\text { Region }\end{array}$} \\
\hline anská Bystrica & 0.2 & $\begin{array}{lllllll}12.3 & 0.1 & 0.5 & 2.9 & 0.2 & 0.7 & 3 .\end{array}$ & 4.0 \\
\hline Banská Štiav & $\begin{array}{lll}0.0 & 0.9 & 0.6\end{array}$ & $\begin{array}{lllllllll}10.3 & 0.0 & 0.5 & 1.5 & 0.2 & 0.7 & 3.1 & 0.3 & 0.1\end{array}$ & 4.0 \\
\hline Brezno & $\begin{array}{lll}0.0 & 1.5 & 1.3\end{array}$ & $\begin{array}{lllllllll}10.8 & 0.1 & 0.5 & 1.9 & 0.2 & 1.4 & 2.9 & 0.5 & 0.2\end{array}$ & 7.4 \\
\hline Detva & $\begin{array}{llll}0.0 & 1.0 & 0.2\end{array}$ & $\begin{array}{lllllllll}7.9 & 0.1 & 0.3 & 1.3 & 0.3 & 1.1 & 6.6 & 0.5 & 0.2\end{array}$ & 4.0 \\
\hline rupina & 0.10 .90 .8 & $\begin{array}{lllllllll}10.2 & 0.1 & 0.5 & 1.6 & 0.2 & 1.4 & 3.9 & 0.4 & 0.1\end{array}$ & 5.0 \\
\hline učenec & $\begin{array}{lll}0.0 & 0.5 & 0.2\end{array}$ & $\begin{array}{lllllllll}9.8 & 0.1 & 0.3 & 1.3 & 0.1 & 1.3 & 4.1 & 0.3 & 0.2\end{array}$ & 2.3 \\
\hline Poltár & $\begin{array}{lll}0.0 & 0.9 & 0.2\end{array}$ & $\begin{array}{lllllllll}7.5 & 0.1 & 0.4 & 1.1 & 0.1 & 0.9 & 5.1 & 0.4 & 0.3\end{array}$ & 4.0 \\
\hline evúca & 0.01 .40 .6 & $\begin{array}{lllllllll}11.6 & 0.4 & 0.6 & 2.2 & 0.1 & 0.7 & 1.6 & 0.5 & 1.5\end{array}$ & 6.7 \\
\hline Rimavská Sobota & $\begin{array}{lll}0.1 & 0.6 & 0.3\end{array}$ & $\begin{array}{lllllllll}8.2 & 0.1 & 0.4 & 0.9 & 0.1 & 0.6 & 1.9 & 0.3 & 0.4\end{array}$ & 3.3 \\
\hline Vel'ký K & $\begin{array}{lll}0.0 & 0.8 & 0.1\end{array}$ & $\begin{array}{lllllllll}7.3 & 0.1 & 0.4 & 1.6 & 0.1 & 1.0 & 2.3 & 0.3 & 0.4\end{array}$ & 2.4 \\
\hline Zvolen & $\begin{array}{lll}0.0 & 0.9 & 0.3\end{array}$ & $\begin{array}{lllllllll}12.5 & 0.1 & 0.4 & 2.2 & 0.1 & 1.4 & 4.3 & 0.3 & 0.1\end{array}$ & 3.8 \\
\hline Žarn & $\begin{array}{lll}0 & 0.9 & 1.7\end{array}$ & $\begin{array}{lllllllll}8.3 & 0.1 & 0.4 & 0.9 & 0.2 & 1.0 & 4.7 & 0.6 & 0.0\end{array}$ & 4.0 \\
\hline Žiar nad Hronom & $\begin{array}{lll}0.0 & 0.7 & 0.2\end{array}$ & $\begin{array}{lllllllll}10.4 & 0.1 & 0.5 & 1.4 & 0.1 & 1.1 & 4.9 & 0.4 & 0.1\end{array}$ & 4.8 \\
\hline \multicolumn{4}{|l|}{ Prešovský Regio } \\
\hline Bardejov & $\begin{array}{lll}0.0 & 0.7 & 0.4\end{array}$ & $\begin{array}{lllllllll}7.7 & 0.1 & 0.6 & 1.2 & 0.2 & 1.4 & 1.8 & 0.6 & 1.5\end{array}$ & 2.1 \\
\hline umenné & $\begin{array}{lll}0.0 & 0.7 & 0.2\end{array}$ & $\begin{array}{lllllllll}10.8 & 0.1 & 0.5 & 2.1 & 0.2 & 1.7 & 2.0 & 0.4 & 0.3\end{array}$ & 1.8 \\
\hline Kežmarok & $\begin{array}{lll}0.0 & 1.0 & 0.3\end{array}$ & $\begin{array}{lllllllll}12.3 & 0.2 & 0.7 & 1.0 & 0.2 & 1.4 & 2.0 & 0.4 & 2.9\end{array}$ & 4.9 \\
\hline Levoča & $\begin{array}{lll}0.1 & 0.6 & 0.2\end{array}$ & $\begin{array}{lllllllll}11.1 & 0.2 & 1.0 & 1.5 & 0.2 & 0.8 & 1.9 & 0.5 & 1.4\end{array}$ & 5.2 \\
\hline Medzilaborce & $\begin{array}{llll}0.0 & 1.4 & 0.2\end{array}$ & $\begin{array}{lllllllll}6.7 & 0.3 & 0.6 & 1.0 & 0.1 & 2.4 & 1.5 & 0.3 & 0.1\end{array}$ & 1.2 \\
\hline Poprad & $\begin{array}{lll}0.0 & 0.6 & 0.2\end{array}$ & $\begin{array}{lllllllll}13.6 & 0.1 & 0.6 & 2.3 & 0.2 & 1.3 & 2.0 & 0.4 & 0.7\end{array}$ & 4.6 \\
\hline rešov & $\begin{array}{lll}0.0 & 0.5 & 0.3\end{array}$ & $\begin{array}{lllllllll}11.2 & 0.1 & 0.6 & 2.4 & 0.1 & 1.6 & 1.9 & 0.4 & 0.7\end{array}$ & 3.3 \\
\hline Sabinov & 0.01 .60 .7 & $\begin{array}{lllllllll}8.5 & 0.2 & 0.6 & 0.9 & 0.3 & 1.2 & 2.4 & 1.0 & 2.1\end{array}$ & 3.7 \\
\hline nina & 0.01 .20 .6 & $\begin{array}{lllllllll}7.3 & 0.2 & 0.4 & 1.0 & 0.2 & 0.9 & 2.8 & 0.5 & 0.3\end{array}$ & 1.9 \\
\hline Stará L’ubc & $\begin{array}{lll}0.0 & 0.8 & 0.5\end{array}$ & $\begin{array}{lllllllll}7.0 & 0.2 & 0.6 & 1.7 & 0.3 & 2.4 & 2.5 & 0.6 & 0.5\end{array}$ & 2.5 \\
\hline Stropkov & $\begin{array}{lll}0.0 & 0.5 & 0.5\end{array}$ & $\begin{array}{lllllllll}9.2 & 0.1 & 0.7 & 1.0 & 0.1 & 1.5 & 2.4 & 0.6 & 0.2\end{array}$ & 2.0 \\
\hline Svidník & $\begin{array}{lll}0.0 & 0.8 & 0.3\end{array}$ & $\begin{array}{lllllllll}7.7 & 0.2 & 0.6 & 1.2 & 0.1 & 1.2 & 3.3 & 0.6 & 1.0\end{array}$ & 1.9 \\
\hline Vranov nad Topl'ou & $\begin{array}{lll}0.0 & 1.1 & 0.2\end{array}$ & $\begin{array}{lllllllll}8.5 & 0.2 & 0.5 & 1.1 & 0.2 & 1.6 & 2.4 & 0.5 & 1.6\end{array}$ & 4.0 \\
\hline
\end{tabular}




\section{Košický Region}

Gelnica

Košice I

Košice II

Košice III

Košice IV

Košice - okolie

Michalovce

Rožňava

Sobrance

Spišská Nová Ves

Trebišov $\begin{array}{lllllllllllll}0.0 & 0.7 & 0.3 & 9.6 & 0.2 & 0.7 & 1.3 & 0.3 & 0.8 & 2.2 & 0.6 & 1.3 & 5.1\end{array}$

$\begin{array}{lllllllllllll}0.0 & 0.2 & 0.2 & 12.9 & 0.1 & 0.5 & 3.5 & 0.1 & 0.6 & 1.9 & 0.1 & 0.1 & 2.0\end{array}$

$\begin{array}{lllllllllllll}0.0 & 0.2 & 0.1 & 14.7 & 0.1 & 0.6 & 4.0 & 0.1 & 0.8 & 1.8 & 0.2 & 0.3 & 2.6\end{array}$

$\begin{array}{llllllllllllll}0.0 & 0.3 & 0.2 & 15.1 & 0.1 & 0.8 & 4.6 & 0.1 & 0.5 & 1.9 & 0.2 & 0.1 & 2.9\end{array}$

$\begin{array}{lllllllllllll}0.0 & 0.3 & 0.2 & 13.1 & 0.0 & 0.7 & 3.3 & 0.1 & 0.7 & 1.8 & 0.3 & 0.2 & 2.3\end{array}$

$\begin{array}{lllllllllllll}0.0 & 0.6 & 0.1 & 11.4 & 0.2 & 0.7 & 1.6 & 0.1 & 0.6 & 1.6 & 0.6 & 0.9 & 2.8\end{array}$

$\begin{array}{lllllllllllll}0.0 & 0.6 & 0.7 & 10.2 & 0.1 & 0.5 & 2.0 & 0.1 & 1.1 & 2.2 & 0.4 & 0.3 & 3.1\end{array}$

$\begin{array}{llllllllllllll}0.0 & 0.6 & 0.2 & 7.4 & 0.1 & 0.3 & 2.4 & 0.4 & 1.5 & 1.3 & 0.4 & 1.2 & 3.7\end{array}$

$\begin{array}{llllllllllllll}0.0 & 0.7 & 1.1 & 7.9 & 0.2 & 0.5 & 1.1 & 0.2 & 1.2 & 5.8 & 0.9 & 0.2 & 2.5\end{array}$

$\begin{array}{llllllllllllll}0.0 & 0.4 & 0.2 & 12.0 & 0.2 & 0.6 & 2.0 & 0.2 & 1.2 & 1.9 & 0.5 & 1.8 & 5.2\end{array}$

$\begin{array}{lllllllllllll}0.0 & 0.5 & 0.4 & 10.6 & 0.1 & 0.4 & 1.2 & 0.1 & 0.8 & 1.6 & 0.4 & 0.6 & 2.2\end{array}$

\begin{tabular}{|c|c|c|}
\hline$\#$ & Abbreviation & Full name of political party / movement \\
\hline 1 & SZS & Strana zelených na Slovensku \\
\hline 2 & SDKÚ & Slovenská demokratická a krest’anská únia \\
\hline 3 & SDPO & Strana za demokratické práva občanov \\
\hline 4 & SDL & Strana demokratickej lavice \\
\hline 5 & SMER & SMER \\
\hline 6 & HZDS & Hnutie za demokratické Slovensko \\
\hline 7 & OKS & Občianska konzervatívna strana \\
\hline 8 & HZD & Hnutie za demokraciu \\
\hline 9 & ROMA & Politické hnutie Rómov na Slovensku - ROMA \\
\hline 10 & KSS & Komunistická strana Slovenska \\
\hline 11 & SMK-MKP & Strana mad’arskej koalície - Magyar Koalíció Pártja \\
\hline 12 & $\mathrm{KDH}$ & Krest’anskodemokratické hnutie \\
\hline 13 & LS & L’udová strana \\
\hline 14 & ZRS & Združenie robotníkov Slovenska \\
\hline 15 & L'B & Lavicový blok \\
\hline 16 & ANO & Aliancia nového občana \\
\hline 17 & B-RRS & Béčko - Revolučná robotnícka strana \\
\hline 18 & ŽAR & Žena a rodina \\
\hline 19 & SDA & Sociálnodemokratická alternatíva \\
\hline 20 & SNJ & Slovenská národná jednota \\
\hline 21 & NOSNP & Nezávislá občianska strana nezamestnaných a poškodených \\
\hline 22 & SNS & Slovenská národná strana \\
\hline 23 & ROSA & Robotnícka strana ROSA \\
\hline 24 & ROISR & Rómska občianska iniciatíva SR \\
\hline 25 & P SNS & Pravá Slovenská národná strana \\
\hline
\end{tabular}


VITA

\section{ZUZANA HLAVÁČOVÁ}

1997

Bachelor of Science in Business Administration

University of Economic

Bratislava, Slovak Republic

2000

Master of Arts in Political Science

Minnesota State University

Mankato, Minnesota

$2004-2009$

Assistant Director

Chapman Graduate School of Business

Florida International University

Miami, Florida 